INSTITUTO DE PESQUISAS ENERGÉTICAS E NUCLEARES

Autarquia associada à Universidade de São Paulo

MECANISMOS DE ATIVAÇÃO MECÂNICA DE MISTURAS DE NIÓBIO E ALUMÍNIO PARA A SÍNTESE POR REAÇÃO DO NbAl

Cláudio José da Rocha

Tese apresentada como parte dos requisitos para obtenção do Grau de Doutor em Ciências na Área de Tecnologia Nuclear - Materiais.

Orientador:

Dr. Ricardo Mendes Leal Neto

SÃO PAULO 
Dedico este trabalho à Andréa, minha futura esposa, e à Giovanna, minha filha do coração. 
Agradecimentos

A pesquisa científica é sempre fruto de um trabalho coletivo. Portanto, agradeço a todos a aqueles que me ajudaram, direta e indiretamente, na realização dessa tese.

Em especial, ao Prof.Dr. Ricardo Mendes Leal Neto, orientador desse trabalho e também um grande amigo, pelo exemplo de ética profissional, pelo cuidado e paciência em vários momentos ao longo deste trabalho e, sobretudo, por ter me dado à oportunidade de fazer parte de sua equipe de pesquisa.

Ao Dr. Flávio Machado de Souza Carvalho, pelo cuidado com que realizou as difrações de raios $X$ e também pela disposição em discutir questões referentes a este trabalho.

Ao Dr. Reginaldo Muccillo, que em vários momentos da pesquisa disponibilizou os laboratórios de difração de raios $X$ e de análise térmica, e parte de seu tempo para realizar análises criticas dos resultados parciais deste trabalho.

Ao Dr. José Roberto Martinelli e à Dra. Marilene Morelli Serna, pelo cuidado e presteza na realização das análises granulométricas.

À Profa. Dra. Vera Lucia Mazzocchi, pelas discussões sobre a técnica de raios $\mathrm{X}$ e por dedicar parte de seu tempo no exame deste trabalho,

À Dra. Dolores Ribeiro Ricci Lazar, por ter cedido o pó de ítria utilizado como padrão de difração de raios $X$.

Ao Prof. Dr. Hugo Ricardo Zschommler Sandim, por ter aceitado prontamente a participar da banca examinadora e por ter cedido o pó de nióbio, sem o qual essa pesquisa não teria sido possível.

Aos membros da banca Prof. Dr. José Deodoro Trani Capocchi, Prof. Dr. Luís Filipe Carvalho Pedroso de Lima, Prof. Dr. Luís Gallego Martinez, Prof. Dr. Jan Vatavuk pelo tempo dedicado à análise crítica desta tese.

À Alluvium Tecnologia em Metais Preciosos Ltda., empresa integrante do Centro Incubador de Empresas Tecnológicas - CIETEC, vinculado ao IPEN, pela permissão de utilização de suas instalações em vários momentos deste trabalho.

À Fundação de Amparo à Pesquisa do Estado de São Paulo - FAPESP _ pelo suporte financeiro ao projeto de pesquisa $n^{\circ}$ 01/03961-4.

A todos os meus amigos, por que sem eles o que seria de mim. 
"O que nos diferencia dos animais não é a inteligência e sim a ética."

Cláudio J. Rocha 


\title{
MECANISMOS DE ATIVAÇÃO MECÂNICA DE MISTURAS DE NIÓBIO E ALUMÍNIO PARA A SÍNTESE POR REAÇÃO DO NbAl ${ }_{3}$
}

\author{
Cláudio José da Rocha
}

\section{RESUMO}

Neste trabalho, a moagem com alta energia foi utilizada para a ativação mecânica de misturas de pós de alumínio e nióbio, na proporção de $75 \%$ atômico de alumínio, para a síntese por reação de combustão do $\mathrm{NbAl}_{3}$. O objetivo foi investigar os mecanismos de ativação atuantes e a eventual preponderância de um deles. A moagem foi realizada tanto nos pós de alumínio e de nióbio separadamente (pré-ativação), como nas misturas. O processo de síntese por reação foi realizado no modo combustão simultânea, em pastilhas compactadas a partir de misturas com e sem ativação mecânica. O comportamento térmico das pastilhas foi registrado durante todo o ciclo térmico de aquecimento e, as principais características térmicas da reação de combustão, foram determinadas. O parâmetro de rede, o tamanho de cristalito e a microdeformação elástica do alumínio e do nióbio foram determinados por difratometria de raios $\mathrm{X}$, mediante análise pelo método de Rietveld. A microscopia eletrônica de varredura foi utilizada para caracterização microestrutural dos pós moídos e da pastilha reagida. Constatou-se que o mecanismo preponderante de ativação mecânica é o aumento da área de interface, que ocorre durante a formação de agregados de partículas de alumínio e nióbio. A eficiência na formação de interfaces diminuiu com a utilização de nióbio pré-ativado (encruado) e com o aumento da quantidade de ácido esteárico (utilizado como agente controlador de processo durante a moagem). $O$ efeito principal da ativação mecânica na síntese por reação de combustão foi a redução da temperatura de ignição com o aumento do tempo de moagem. A alta densidade de defeitos cristalinos, gerada durante a pré-ativação dos pós de alumínio e nióbio e na ativação mecânica das misturas, não produziu efeitos mensuráveis sobre o comportamento térmico das pastilhas. 


\title{
MECHANICAL ACTIVATION MECHANISMS OF NIOBIUM AND ALUMINIUM MIXTURES FOR THE REACTION SYNTHESIS OF NbAl ${ }_{3}$
}

\author{
Cláudio José da Rocha
}

\begin{abstract}
In this work, mechanical activation of mixtures of niobium and aluminum powders ( 75 at.\% of $\mathrm{Al}$ ) was carried out by high energy ball milling, in order to produce $\mathrm{NbAl}_{3}$ by combustion synthesis. The purpose was to investigate activation mechanisms present and the eventual preponderancy of one of them. Beside mixtures, aluminum and niobium powders were separately activated by milling (pre-activation). Reaction synthesis, by simultaneous combustion mode, was conducted on compacted pellets made of activated and non-activated powder mixtures. The thermal behavior of the compacted pellets upon heating was recorded and main thermal characteristics of the combustion reaction were evaluated. Lattice parameter, crystallite size and microstrain for niobium and aluminum were measured by X-ray diffraction analysis, using the Rietveld method. Scanning electron microscopy was used for microstructural characterization of milled powders and reacted pellets. The growth of interface area in the aggregates of aluminum and niobium, formed during milling, was shown to be the main activation mechanism. Both pre-activated niobium and increased quantities of stearic acid (milling process control agent) hinder the interface formation. The main effect of mechanical activation in the reaction synthesis was to reduce the ignition temperature with the increase of the milling time. High density of crystal defects attained during milling (pre-activation of single powders or activation of the mixtures) produced no measurable effects to the thermal behavior of pellets.
\end{abstract}


SUMÁRIO

1 INTRODUÇÃO

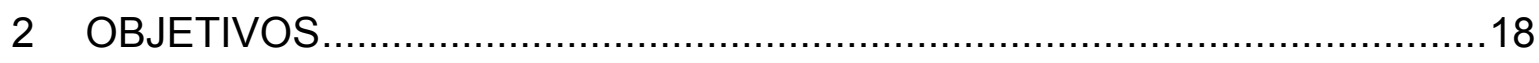

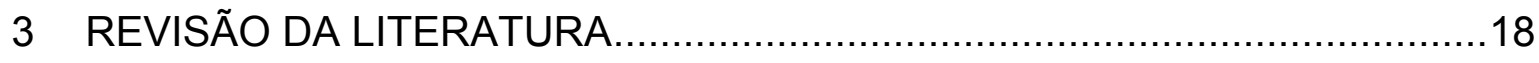

3.1 COMPOSTOS INTERMETÁLICOS À BASE DE ALUMÍNIO ....................18

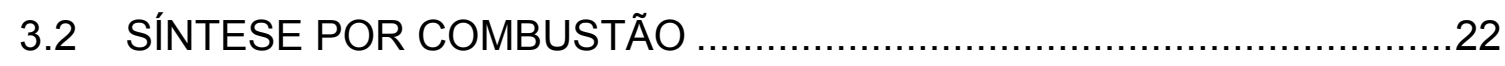

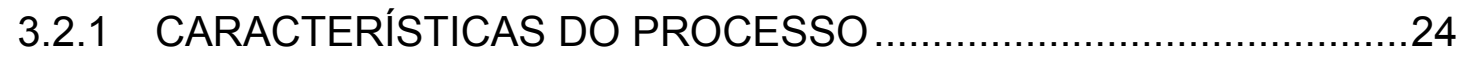

3.2.2 CONSIDERAÇÕES TERMODINÂMICAS DO PROCESSO ..............26

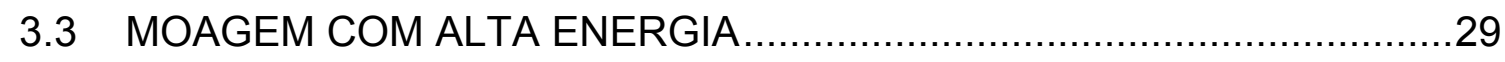

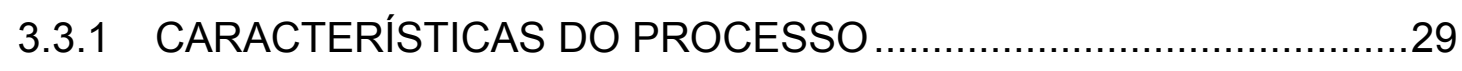

3.3.2 ATIVAÇÃO MECÂNICA NA MOAGEM COM ALTA ENERGIA...........33

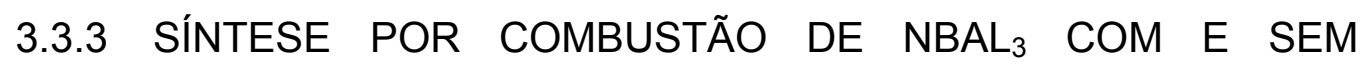

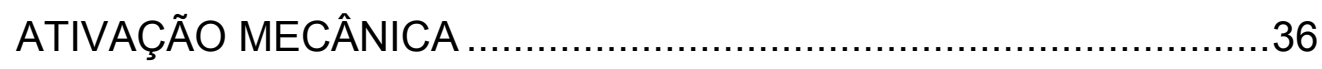

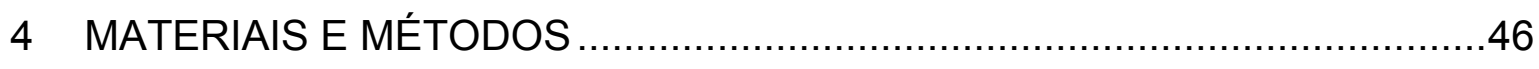

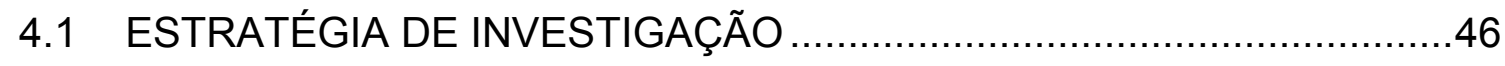

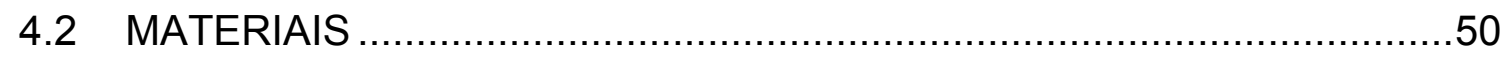

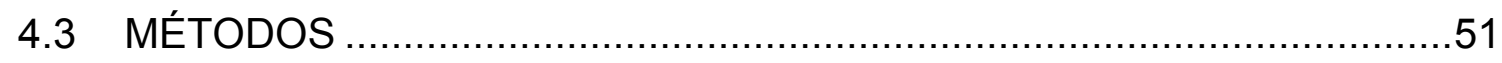

4.3.1 PROCEDIMENTO DE PRÉ-ATIVAÇÃO E RECOZIMENTO...............51

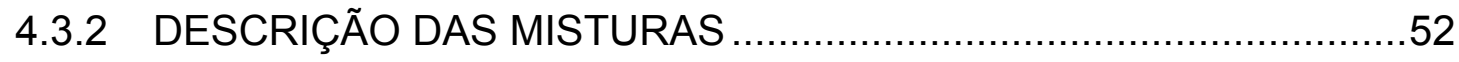

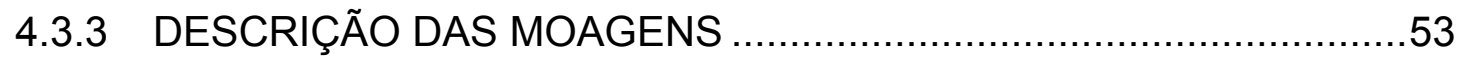

4.3.4 CARACTERIZAÇÃO DOS MATERIAIS APÓS MOAGEM …...............54

4.3.5 DESCRIÇÃO DAS COMPACTAÇÕES ……...................................5

4.3.6 DESCRIÇÃO DOS CICLOS TÉRMICOS ........................................56

4.3.7 CARACTERIZAÇÃO DOS CICLOS TÉRMICOS ……......................58 
5 RESULTADOS 60

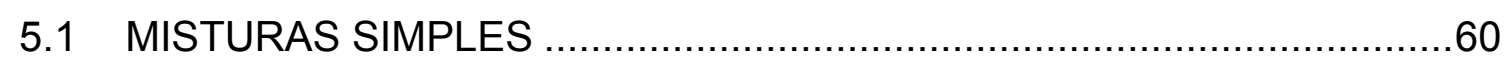

5.1.1 MICROSCOPIA E DISTRIBUIÇÃO GRANULOMÉTRICA ................61

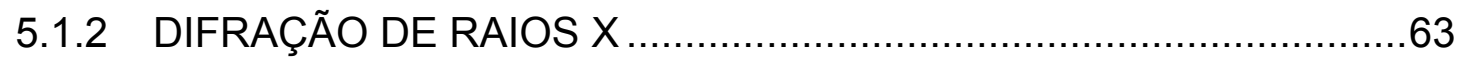

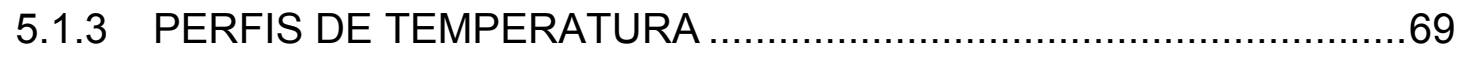

5.1.4 MICROESTRUTURA DAS PASTILHAS ……...............................

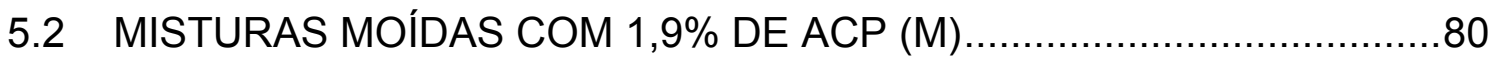

5.2.1 MICROSCOPIA E DISTRIBUIÇÃO GRANULOMÉTRICA .................81

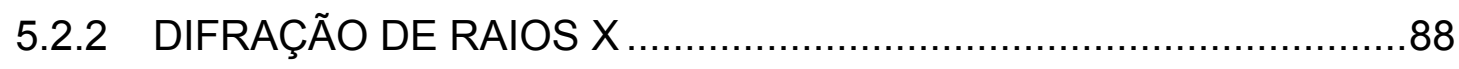

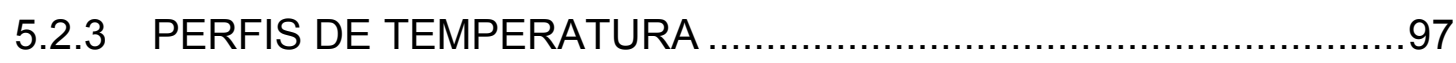

5.2.4 MICROESTRUTURA DAS PASTILHAS ….................................102

5.3 MISTURAS MOÍDAS COM 1,0\% DE ACP (M1) ...............................109

5.3.1 MICROSCOPIA E DISTRIBUIÇÃO GRANULOMÉTRICA ...............109

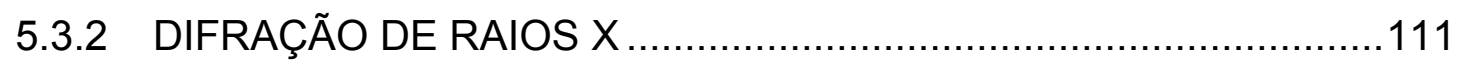

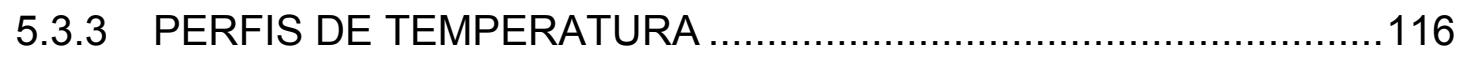

5.3.4 MICROESTRUTURA DAS PASTILHAS …................................118

6 DISCUSSÃO

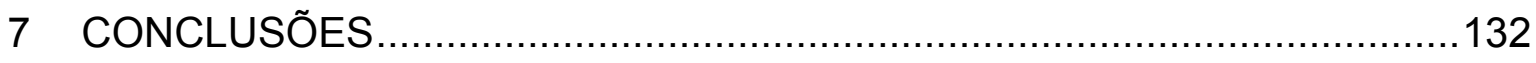

8 SUGESTÕES PARA TRABALHOS FUTUROS .........................................134

9 ANEXO

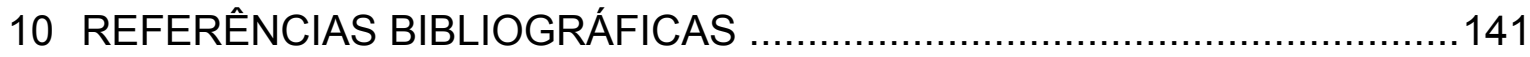




\section{LISTA DE TABELAS}

TABELA 1 - Propriedades de alguns aluminetos e silicetos de interesse tecnológico (Baker e George, 1992).

TABELA 2 - Condições de moagem adotadas no procedimento de pré-ativação.

TABELA 3 - Codificação das misturas de pós de alumínio e nióbio utilizadas.

TABELA 4 - Condições adotadas nas moagens de misturas. 53

TABELA 5 - Tamanho de cristalito, microdeformação e parâmetro de rede do alumínio nas condições pré-ativada e recozida.

TABELA 6 - Tamanho de cristalito, microdeformação e parâmetro de rede do nióbio nas condições pré-ativada e recozida.

TABELA 7 - Valores característicos dos perfis de temperatura das pastilhas preparadas a partir de misturas de reagentes como recebidos (SCR), pré-ativados (SPA) e pré-ativados e recozidos (SPA-R)

TABELA 8 - Valores característicos dos perfis de temperatura das pastilhas preparadas a partir de misturas com apenas o alumínio no estado pré-ativado (SPA-A) e de misturas com apenas o nióbio no estado pré-ativado (SPA-N). Valores das mistura SCR e SPA apresentados conjuntamente para fins comparativos.

TABELA 9 - Tamanho de cristalito e microdeformação da fase $\mathrm{Nb}(\mathrm{H})$ na mistura tipo MCR após moagem de 120 minutos.

TABELA 10 -Tamanho de cristalito, microdeformação e parâmetro de rede do alumínio em misturas de reagentes como recebidos (MCR), após moagem de 20 e 120 minutos.

TABELA 11 -Tamanho de cristalito, microdeformação e parâmetro de rede do nióbio em misturas de reagentes como recebidos (MCR) após moagem de 20 e 120 minutos.

TABELA 12 -Tamanho de cristalito, microdeformação e parâmetro de rede do alumínio em misturas de reagentes como recebidos (MCR) e de reagentes pré-ativados (MPA), após 120 minutos de moagem.

TABELA 13 -Tamanho de cristalito, microdeformação e parâmetro de rede do nióbio em misturas de reagentes como recebidos (MCR) e de reagentes pré-ativados (MPA), após 120 minutos de moagem

TABELA 14 -Tamanho de cristalito, microdeformação e parâmetro de rede do alumínio em misturas tipo MPA-A e MPA-N, após 120 minutos de moagem. 
TABELA 15 -Tamanho de cristalito, microdeformação e parâmetro de rede do nióbio em misturas tipo MPA-A e MPA-N, após 120 minutos de moagem.

TABELA 16 -Valores característicos dos perfis de temperatura para pastilhas preparadas a partir de misturas moídas de reagentes como recebidos (MCR), pré-ativados (MPA) e pré-ativados e recozidos (MPA-R). Tempos de moagem de 20 e 120 minutos.

TABELA 17 -Valores característicos dos perfis de temperatura das pastilhas preparadas a partir de misturas moídas com apenas o alumínio no estado pré-ativado (SPA-A) e de misturas moídas com apenas o nióbio no estado pré-ativado (SPA-N). Tempos de moagem de 20 e 120 minutos.

TABELA 18 -Tamanho de cristalito, microdeformação e parâmetro de rede do alumínio em misturas moídas com 1,0\%(M1CR) e $1,9 \%(M C R)$ de ACP, após moagem de 20 minutos.

TABELA 19 -Tamanho de cristalito, microdeformação e parâmetro de rede do alumínio em misturas tipo com 1,0\%(M1CR) e 1,9\%(MCR) de ACP, após moagem de 120 minutos

TABELA 20 -Tamanho de cristalito, microdeformação e parâmetro de rede do nióbio em misturas moídas com 1,0\%(M1CR) e 1,9\%(MCR) de ACP, após moagem de 20 minutos

TABELA 21 -Tamanho de cristalito, microdeformação e parâmetro de rede do nióbio em misturas moídas com 1,0\%(M1CR) e 1,9\%(MCR) de ACP, após moagem de 120 minutos

TABELA 22 -Tamanho de cristalito, microdeformação e parâmetro de rede da fase $\mathrm{Nb}(\mathrm{H})$, em misturas moídas com 1,0\%(M1CR) e $1,9 \%(\mathrm{MCR})$ de ACP, após moagem de 120 minutos.

TABELA 23 -Valores característicos do perfil de temperatura para pastilhas preparadas a partir de misturas de reagentes como recebidos, moidas com $1 \%$ de ACP (M1CR) e 1,9\% de ACP (MCR). Tempos de moagem de 20 e 120 minutos.

TABELA 24 -Valores característicos dos perfis de temperatura para pastilhas preparadas a partir de misturas simples.

TABELA 25 -Valores característicos dos perfis de temperatura para pastilhas preparadas a partir de misturas com 20 minutos de moagem.

TABELA 26 -Valores característicos dos perfis de temperatura para pastilhas preparadas a partir de misturas com 120 minutos de moagem.

TABELA 27 -Tamanho de cristalito, microdeformação e parâmetro de rede do alumínio e do nióbio pré-ativados e em misturas com 120 minutos de moagem. 


\section{LISTA DE FIGURAS}

FIGURA 1 - Células cristalinas das fases que compõem o sistema Al-Nb. Dados cristalográficos coletados das fichas ICSD ("Inorganic Crystal Structure Database") 64700, 58015, 58013, 58014 e 44380

FIGURA 2 - Diagrama de equilíbrio das fases encontradas no sistema Al-Nb (Massalski, 1996).

FIGURA 3 - Síntese por combustão no modo SHS de uma mistura compactada de Ti-B. (a) Aquecimento localizado e ignição, $t=$ 0 s; (b) e (c) propagação da frente de reação, $t=1 \mathrm{~s}$ e t $=2,7 \mathrm{~s}$; (d) resfriamento após o término da reação, t $=4 \mathrm{~s}$ (Merzhanov, 1997).

FIGURA 4 - Variação da entalpia da mistura de Nb-Al e do intermetálico $\mathrm{NbAl}_{3}$ em função da temperatura, calculada a partir dos dados disponíveis na literatura (Barin, 1989; Shilo et al., 1982).

FIGURA 5 - Seqüência esquemática de eventos durante a moagem com alta energia de misturas dúcteis (Benjamin e Volin, 1974).

FIGURA 6 - Perfil esquemático da variação da temperatura de uma amostra do sistema $\mathrm{Al}-\mathrm{Nb}$ submetida a um ciclo térmico de reação de combustão simultânea (Kachelmyer et al., 1995).

FIGURA 7 - Efeito do tempo de moagem com alta energia no comportamento térmico e na microestrutura dos agregados de misturas $\mathrm{Nb}_{25} \mathrm{Al}_{75}$ (Leal Neto e Rocha, 2001)....

FIGURA 8 - Quadro comparativo da seqüência de preparação dos reagentes utilizados nas misturas simples e nas misturas moídas.

FIGURA 9 - Tipos de misturas simples avaliadas e suas codificações.

FIGURA 10 - Tipos de misturas moídas avaliadas e suas codificações. 48

FIGURA 11 -Exemplo de perfil de temperatura da pastilha registrado pelo sistema de aquisição de dados.

FIGURA 12 -Exemplo da metodologia de análise dos perfis de temperatura.......59

FIGURA 13 -Micrografias e distribuições de tamanho de partículas do alumínio nas condições como recebida e pré-ativada.

FIGURA 14 - Micrografias e distribuições de tamanho de partículas do nióbio nas condições como recebida e pré-ativada. 
FIGURA 15 -Difratogramas dos pós de alumínio pré-ativado e após tratamento de recozimento, analisados pelo método de Rietveld.

FIGURA 16 -Difratogramas dos pós de nióbio pré-ativado e após tratamento de recozimento, analisados pelo método de Rietveld.

FIGURA 17 -Perfis de temperatura e de diferença de temperatura entre pastilha e forno, referentes às pastilhas preparadas com misturas de reagentes como recebidos, SCR (A e B), préativados, SPA (C e D) e pré-ativados e recozidos, SPA-R (E e F).

FIGURA 18 -Perfis de temperatura $(A)$ e de diferença de temperatura entre pastilha e forno $(B)$, referentes às pastilhas preparadas com misturas de reagentes como recebidos (SCR), pré-ativados (SPA) e pré-ativados e recozidos, SPA-R

FIGURA 19 -Perfis de temperatura e de diferença de temperatura entre pastilha e forno, referentes às pastilhas preparadas a partir de misturas com apenas o alumínio no estado pré-ativado, SPA-A (A e B), e de mis-turas com apenas o nióbio no estado préativado, SPA-N (C e D).

FIGURA 20 -Micrografias de pastilhas reagidas e de pastilhas com interrupção de aquecimento antes da ignição, referentes às misturas de reagentes como recebidos (SCR) e de reagentes pré-ativados (SPA). Microscopia eletrônica de varredura com imagem de elétrons retroespalhados.

FIGURA 21 -Micrografias de pastilhas reagidas e de pastilhas com interrupção de aquecimento antes da ignição, referentes às misturas com somente alumínio pré-ativado (SPA-A) e com somente nióbio pré-ativado (SPA-N). Microscopia eletrônica de varredura com imagem de elétrons retroespalhados.

FIGURA 22 - Micrografias de pó solto de misturas moídas a partir de pós como recebidos (MCR) e pré-ativados (MPA), após 20 e 120 minutos de moagem, e distribuições de tamanho de partícula das misturas com 120 minutos de moagem. Microscopia eletrônica de varredura com imagem de elétrons retroespalhados.

FIGURA 23 - Micrografias de pó embutido de misturas moídas a partir de pós como recebidos (MCR) e pré-ativados (MPA), após 20 e 120 minutos de moagem. Microscopia eletrônica de varredura com imagem de elétrons retroespalhados. 
FIGURA 24 -Micrografias de pó embutido de misturas de reagentes préativados e recozidos (MPA-R), após 120 minutos de moagem. Microscopia eletrônica de varredura com imagem de elétrons retroespalhados.

FIGURA 25 -Micrografias de pó solto de misturas preparadas a partir de alumínio pré-ativado e nióbio como recebido (MPA-A), após 20 e 120 minutos de moagem, e distribuições de tamanho de partícula das misturas com 120 minutos de moagem. Microscopia eletrônica de varredura com imagem de elétrons retroespalhados.

FIGURA 26 - Micrografias de pó embutido de misturas preparadas a partir de alumínio pré-ativado e nióbio como recebido (MPA-A) após 20 e 120 minutos de moagem. Microscopia eletrônica de varredura com imagem de elétrons retroespalhados.

FIGURA 27 -Micrografias de pó solto de misturas preparadas a partir de alumínio como recebido e nióbio pré-ativado (MPA-N), após 20 e 120 minutos de moagem, e distribuições de tamanho de partícula das misturas com 120 minutos de moagem. Microscopia eletrônica de varredura com imagem de elétrons retroespalhados.

FIGURA 28 - Micrografias de pó embutido de misturas preparadas a partir de alumínio como recebido e nióbio pré-ativado (MPA-N) após 20 e 120 minutos de moagem. Microscopia eletrônica de varredura com imagem de elétrons retroespalhados.

FIGURA 29 -Difratogramas das misturas preparadas a partir de reagentes como recebidos (MCR) após 20 e 120 minutos de moagem, analisados pelo método de Rietveld.

FIGURA 30 -Difratograma da mistura preparada a partir de pós pré-ativados (MPA) após 120 minutos de moagem, analisada pelo método de Rietveld.

FIGURA 31 -Difratogramas das misturas moídas a partir de alumínio préativado e nióbio como recebido (MPA-A) e de alumínio como recebido e nióbio pré-ativado (MPA-N), após 120 minutos de moagem, analisados pelo método de Rietveld.

FIGURA 32 -Perfis de temperatura e de diferença de temperatura entre pastilha e forno, referentes às pastilhas preparadas a partir de misturas moídas de reagentes como recebidos, MCR (A e B), de misturas moídas de reagentes pré-ativados, MPA (C e D), e de misturas de reagentes pré-ativados e recozidos. Tempos de moagem de 20 e 120 minutos. 
FIGURA 33 - Perfis de temperatura e de diferença de temperatura entre pastilha e forno, referentes às pastilhas preparadas a partir de misturas moidas com apenas o alumínio no estado pré-ativado, SPA-A (A e B), e de misturas moídas com apenas o nióbio no estado pré-ativado, SPA-N (C e D). Tempos de moagem de 20 e 120 minutos.

FIGURA 34 -Micrografias de pastilhas reagidas e de pastilhas com interrupção de aquecimento antes da ignição referentes às misturas de reagentes como recebidos (MCR) com 20 e 120 minutos de moagem. Microscopia eletrônica de varredura com imagem de elétrons retroespalhados.

FIGURA 35 -Micrografias de pastilhas reagidas e de pastilhas com interrupção de aquecimento antes da ignição referentes às misturas de reagentes pré-ativados (MPA) com 20 e 120 minutos de moagem. Microscopia eletrônica de varredura com imagem de elétrons retroespalhados.

FIGURA 36 -Micrografias de pastilhas reagidas e de pastilhas com interrupção de aquecimento antes da ignição referentes às misturas de reagentes pré-ativados e recozidos (MPA-R) com 120 minutos de moagem. Microscopia eletrônica de varredura com imagem de elétrons retroespalhados.

FIGURA 37 -Micrografias de pastilhas reagidas e de pastilhas com interrupção de aquecimento antes da ignição referentes às misturas MPA-A (alumínio pré-ativado e nióbio como recebido) e MPA-N (Alumínio como recebido e nióbio pré-ativado) com 20 minutos de moagem. Microscopia eletrônica de varredura com imagem de elétrons retroespalhados.

FIGURA 38 - Micrografias de pastilhas reagidas referentes às misturas MPAA (alumínio pré-ativado e nióbio como recebido) e MPA-N (Alumínio como recebido e nióbio pré-ativado) com 120 minutos de moagem. Microscopia eletrônica de varredura com imagem de elétrons retroespalhados.

FIGURA 39 - Micrografias de pó solto de misturas preparadas a partir de pós como recebidos com $1,0 \%$ de ACP (M1CR) e com $1,9 \%$ de ACP (MCR), após 20 e 120 minutos de moagem, e distribuição granulométrica das misturas com 120 minutos de moagem. Microscopia eletrônica de varredura com imagem de elétrons retroespalhados.

FIGURA 40 - Micrografias de pó embutido de misturas preparadas a partir de pós como recebidos com 1,0\% de ACP (M1CR) e com 1,9\% de ACP (MCR), após 20 e 120 minutos de moagem. Microscopia eletrônica de varredura com imagem de elétrons retroespalhados. 
FIGURA 41 - Difratogramas de misturas moídas com 1\% de ACP, preparadas a partir de reagentes como recebidos (M1CR) após 20 e 120 minutos de moagem. Tempos de moagem de 20 e 120 minutos.

FIGURA 42 - Perfis de temperatura e de diferença de temperatura entre pastilha e forno, referentes às pastilhas preparadas a partir de misturas de reagentes como recebidos, moidas com $1 \%$ de ACP, M1CR (A e B) e 1,9\% de ACP, MCR (C e D). Tempos de moagem de 20 e 120 minutos.

FIGURA 43 -Micrografias de pastilhas reagidas e de pastilhas com interrupção de aquecimento antes da ignição referente às misturas com 1,0\% (M1CR) e 1,9\% (MCR) de ACP, com 20 minutos de moagem. Microscopia eletrônica de varredura com imagem de elétrons retroespalhados.

FIGURA 44 -Micrografias das pastilhas reagidas referente às misturas com $1,0 \%$ (M1CR) e 1,9\% (MCR) de ACP e da pastilha com interrupção de aquecimento antes da ignição referente à mistura com $1,9 \%$ de ACP, todas as misturas com 120 minutos de moagem. Microscopia eletrônica de varredura com imagem de elétrons retroespalhados.

FIGURA 45 - Comparação dos perfis de temperatura e de diferença de temperatura entre pastilha e forno, referentes às pastilhas preparadas a partir de misturas simples.

FIGURA 46 -Comparação dos perfis de temperatura e de diferença de temperatura entre pastilha e forno, referentes às pastilhas preparadas a partir de misturas com 20 minutos de moagem.

FIGURA 47 -Comparação dos perfis de temperatura e de diferença de temperatura entre pastilha e forno, referentes às pastilhas preparadas a partir de misturas com 120 minutos de moagem. ....128 


\section{INTRODUÇÃo}

O tema deste trabalho é fruto da maturação de uma filosofia de pesquisa que se mescla com o nascimento e estruturação do Laboratório de Intermetálicos, integrante do espaço físico do Centro de Ciência e Tecnologia dos Materiais, localizado no Instituto de Pesquisas Energéticas e Nucleares.

Inicialmente as investigações estavam focadas no aspecto microestrutural do processo de síntese por combustão simultânea de ligas nos sistemas $\mathrm{Nb}-\mathrm{Al}$ e $\mathrm{Nb}-\mathrm{Ni}$-Al, buscando entender os mecanismos de reação (Ferreira e Leal Neto, 1994, Leal Neto e Ferreira, 1995, 1999). Uma atenção constante com os mecanismos de densificação das pastilhas reagidas, visando obter uma microestrutura homogênea, dava um cunho tecnológico às pesquisas. Paralelamente, pesquisas sobre a utilização da moagem com alta energia, para obtenção de ligas a partir dos elementos puros, investigavam os efeitos do agente controlador de processo no tamanho de partícula e na formação de ligas $\mathrm{Cu}-\mathrm{Ni}$ (Rocha et al., 1999).

A utilização da moagem com alta energia na preparação de misturas $\mathrm{Nb}_{25} \mathrm{Al}_{75}$ foi inicialmente estudada por análise térmica diferencial, na qual se verificou uma sensível redução da temperatura de ignição da reação de combustão (Leal Neto e Rocha, 2001). Outra conseqüência importante do emprego da moagem com alta energia foi a preservação da forma da pastilha, após a reação de combustão, o que não acontecia no caso das misturas não submetidas à moagem (Leal Neto et al., 2003).

A grande quantidade de variáveis envolvidas na associação dos dois processos tornou-se um desafio quanto à otimização da microestrutura e à obtenção de produtos com baixa porosidade. A utilização de agentes controladores de processo (ACP) mostrou ter efeitos muito significativos no processo de formação de agregados de partículas de nióbio e de alumínio, e na distribuição de tamanho desses agregados (Rocha et al., 2003). O tipo de moinho utilizado também é uma variável importante. O moinho agitador (SPEX®) e o planetário, comumente utilizados na moagem com alta energia, podem produzir agregados com microestruturas muito diferentes, para um mesmo tempo de moagem (Rocha et al., 2006). 
O termo ativação mecânica é comumente empregado para designar as modificações microestruturais produzidas pela moagem com alta energia. A esse processo são creditados efeitos como aumento da densidade de defeitos cristalinos e aumento da área de interface entre partículas dissimilares. Entretanto, cada uma dessas alterações pode resultar em efeitos distintos dependendo do tipo de processamento subseqüente. Nesse âmbito, ao longo das pesquisas foi se maturando a idéia de se avaliar sistematicamente o efeito de cada uma dessas alterações sobre o processo de síntese por combustão simultânea. É nesse contexto que este trabalho se insere. 


\section{OBJETIVOS}

O objetivo principal é estudar os mecanismos de ativação mecânica envolvidos na moagem com alta energia, tais como o aumento na densidade de defeitos cristalinos, provocada pela deformação plástica das partículas, e o aumento da área de interface devido à formação de agregados de partículas de alumínio e nióbio. Ainda como objetivo principal, buscar-se-á avaliar a significância desses mecanismos de ativação, sobre o processo de síntese por reação no modo combustão simultânea.

Um objetivo secundário deste trabalho é avaliar a influência do agente controlador de processo (ACP) nos mecanismos de ativação mecânica.

\section{REVISÃO DA LITERATURA}

\subsection{COMPOSTOS INTERMETÁLICOS À BASE DE ALUMÍNIO}

Os compostos intermetálicos, ou simplesmente intermetálicos, são materiais formados por dois ou mais elementos (metais ou metalóides), cuja ligação química é mais forte entre átomos dissimilares (Sauthoff, 1995). Essa característica afeta diretamente a distribuição dos átomos no espaço, gerando uma rede cristalina diferente das observadas nos respectivos materiais puros. A posição relativa dos átomos nessa nova estrutura cristalina tende a ser fixa, criando uma ordem de distribuição dos átomos, que se mantém por longa distância. Na FIG. 1 estão apresentadas, esquematicamente, as células cristalinas do alumínio, do nióbio e dos intermetálicos formados no sistema Al-Nb.

A ordenação dos átomos, associada à ligação química mais forte entre os átomos dissimilares, confere aos intermetálicos propriedades mecânicas, físicas e químicas que não podem ser interpoladas a partir das propriedades dos elementos puros. Os materiais intermetálicos têm reconhecida potencialidade para aplicações estruturais envolvendo altas temperaturas, (Deevi e Sikka, 1996, Liu et al., 1997; Stoloff et al., 2000). Entretanto, quando à temperatura ambiente, 


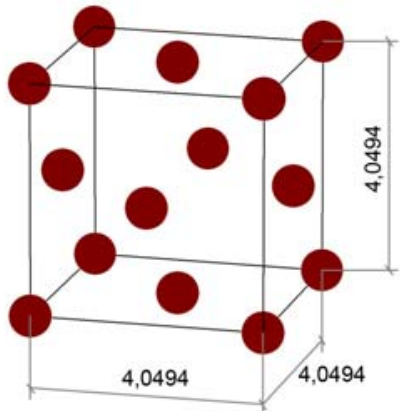

$\mathrm{Al}(\mathrm{A} 1)$

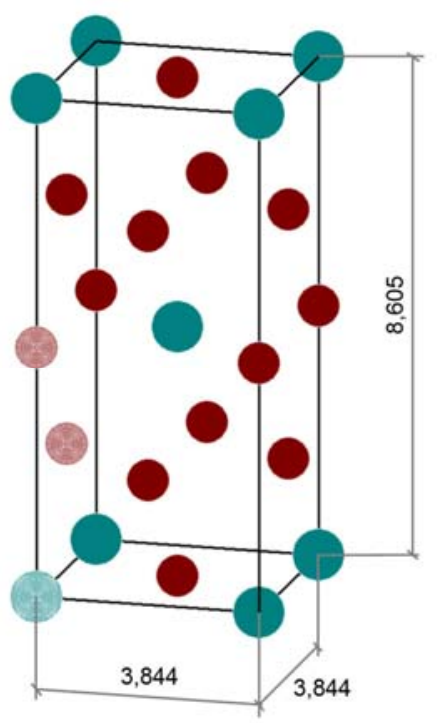

$\mathrm{NbAl}_{3}\left(\mathrm{DO}_{22}\right)$

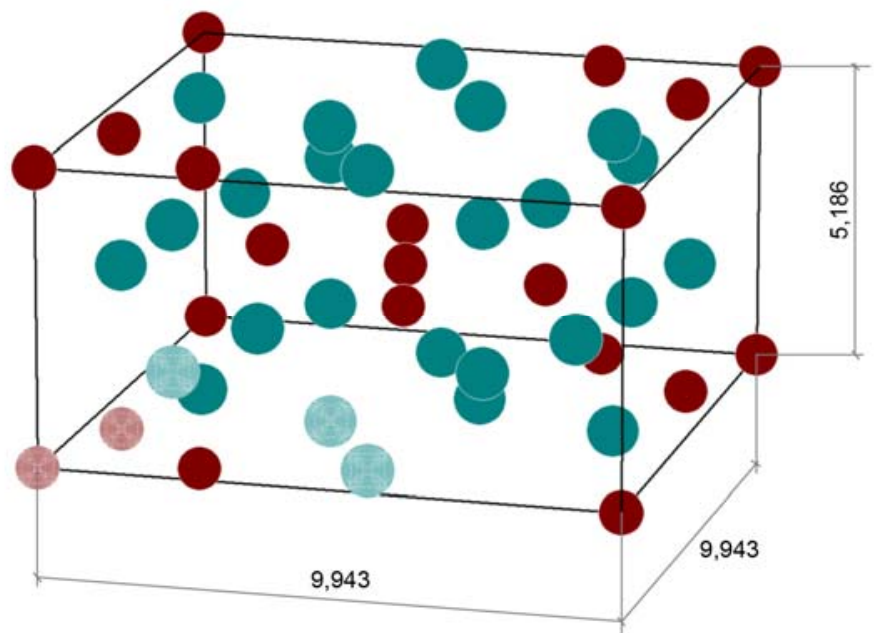

$\mathrm{Nb}_{2} \mathrm{Al}\left(\mathrm{D} 8_{\mathrm{b}}\right)$

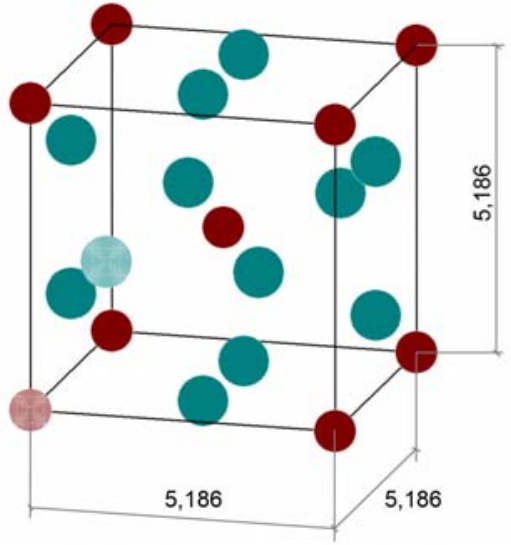

$\mathrm{Nb}_{3} \mathrm{Al}(\mathrm{A} 15)$

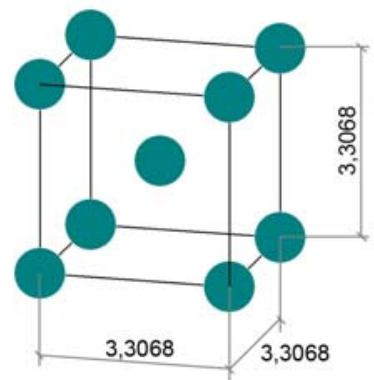

$\mathrm{Nb}(\mathrm{A} 2)$

FIGURA 1 - Células cristalinas das fases que compõem o sistema Al-Nb. Dados cristalográficos coletados das fichas ICSD ("Inorganic Crystal Structure Database") 64700, 58015, 58013, 58014 e 44380. 
a grande maioria possui baixa tenacidade à fratura, o que tem limitado consideravelmente sua utilização. Essa propriedade está relacionada com a baixa simetria da estrutura cristalina da grande maioria dos intermetálicos, o que limita a quantidade de sistemas de escorregamento e aumenta a probabilidade de fratura por clivagem. A ordenação de longa distância também afeta a movimentação de discordâncias devido à formação de contornos de antifase.

Aoki e Izumi (1979) descobriram que pequenas adições de boro ao intermetálico $\mathrm{Ni}_{3} \mathrm{Al}$ aumentavam substancialmente a sua ductilidade. Desde então, muitos trabalhos têm sido desenvolvidos adicionando elementos de liga em diversos sistemas, com o objetivo de superar tal fragilidade (Fleischer, 2005; Cammarota e Casagrande, 2004; Bozzolo et al., 2002, 2000; Cotton et al., 1993a, 1993b). Um dos objetivos da adição de elementos de liga substitucionais é a estabilização da estrutura cúbica $\mathrm{L} 1_{2}$ de maior simetria.

Outra estratégia que tem sido utilizada para melhorar o problema de falta de tenacidade é a formação de compósitos entre a fase intermetálica e metais refratários, como cromo e nióbio, que possuem maior tenacidade (Bewlay et al., 2003; Bei et al., 2004; Ramanujan, 1998). Entretanto, alguns compósitos sofrem fragilização com a exposição a atmosferas contendo oxigênio e hidrogênio (Rigney et al., 1992). Compósitos de matriz intermetálica também oferecem boas combinações de propriedades, porém, a falta de tenacidade à temperatura ambiente ainda persiste (Ward-Close et al., 1996)

Dentro do universo de materiais intermetálicos, os aluminetos e os silicetos são particularmente atrativos, devido à combinação de densidades reduzidas e altos pontos de fusão. Entretanto, a resistência à oxidação a altas temperaturas de alguns sistemas ainda é inferior à apresentada pelas superligas de níquel.

Das fases intermetálicas do sistema binário $\mathrm{Al}-\mathrm{Nb}$, cujo diagrama de equilíbrio é apresentado na FIG.2, o $\mathrm{NbAl}_{3}$ é o único que se funde de forma congruente e, ao contrário dos demais, apresenta uma faixa de variação de composição desprezível, podendo ser considerado um composto de linha. O $\mathrm{NbAl}_{3}$ é um dos aluminetos de menor densidade $\left(4,54 \mathrm{~g} / \mathrm{cm}^{3}\right)$ e de alto ponto de fusão $\left(1680^{\circ} \mathrm{C}\right)$. Na TAB.1 estão listadas informações de estrutura cristalina, temperatura de fusão e densidade para diversos intermetálicos de interesse tecnológico. 
TABELA 1 - Propriedades de alguns aluminetos e silicetos de interesse tecnológico (Baker e George, 1992).

\begin{tabular}{|cccc|}
\hline Intermetálico & $\begin{array}{c}\text { Estrutura } \\
\text { Cristalina* }\end{array}$ & $\begin{array}{c}\text { Temperatura de } \\
\text { fusão }\left({ }^{\circ} \mathrm{C}\right)\end{array}$ & Densidade $\left(\mathrm{g} / \mathrm{cm}^{3}\right)$ \\
\hline $\mathrm{TiAl}_{3}$ & $\mathrm{D0}_{22}$ & 1350 & 3,20 \\
$\mathrm{TiAl}$ & $\mathrm{L} 1_{0}$ & 1460 & 3,91 \\
$\mathrm{Ti}_{3} \mathrm{Al}$ & $\mathrm{D}{ }_{19}$ & 1600 & 4,20 \\
$\mathrm{Ti}_{5} \mathrm{Si}_{3}$ & $\mathrm{D}{ }_{8}$ & 2130 & 4,32 \\
$\mathrm{NbAl}_{3}$ & $\mathrm{D} 0_{22}$ & 1680 & 4,54 \\
$\mathrm{FeAl}$ & $\mathrm{B} 2$ & 1300 & 5,56 \\
$\mathrm{NiAl}$ & $\mathrm{B2}$ & 1640 & 5,86 \\
$\mathrm{MoSi}_{2}$ & $\mathrm{C}_{11 \mathrm{~b}}$ & 2020 & 6,24 \\
$\mathrm{Fe}_{3} \mathrm{Al}$ & $\mathrm{D0}$ & 1540 & 6,72 \\
$\mathrm{Nb}_{3} \mathrm{Al}$ & $\mathrm{A} 15$ & 1960 & 7,29 \\
$\mathrm{Ni}_{3} \mathrm{Si}$ & $\mathrm{L} 1_{2}$ & 1140 & 7,30 \\
$\mathrm{Ni}_{3} \mathrm{Al}$ & $\mathrm{L} 1_{2}$ & 1400 & 7,50 \\
\hline
\end{tabular}

*Designação de acordo com o StrukturBericht

\section{$\mathrm{Al}-\mathrm{Nb}$}

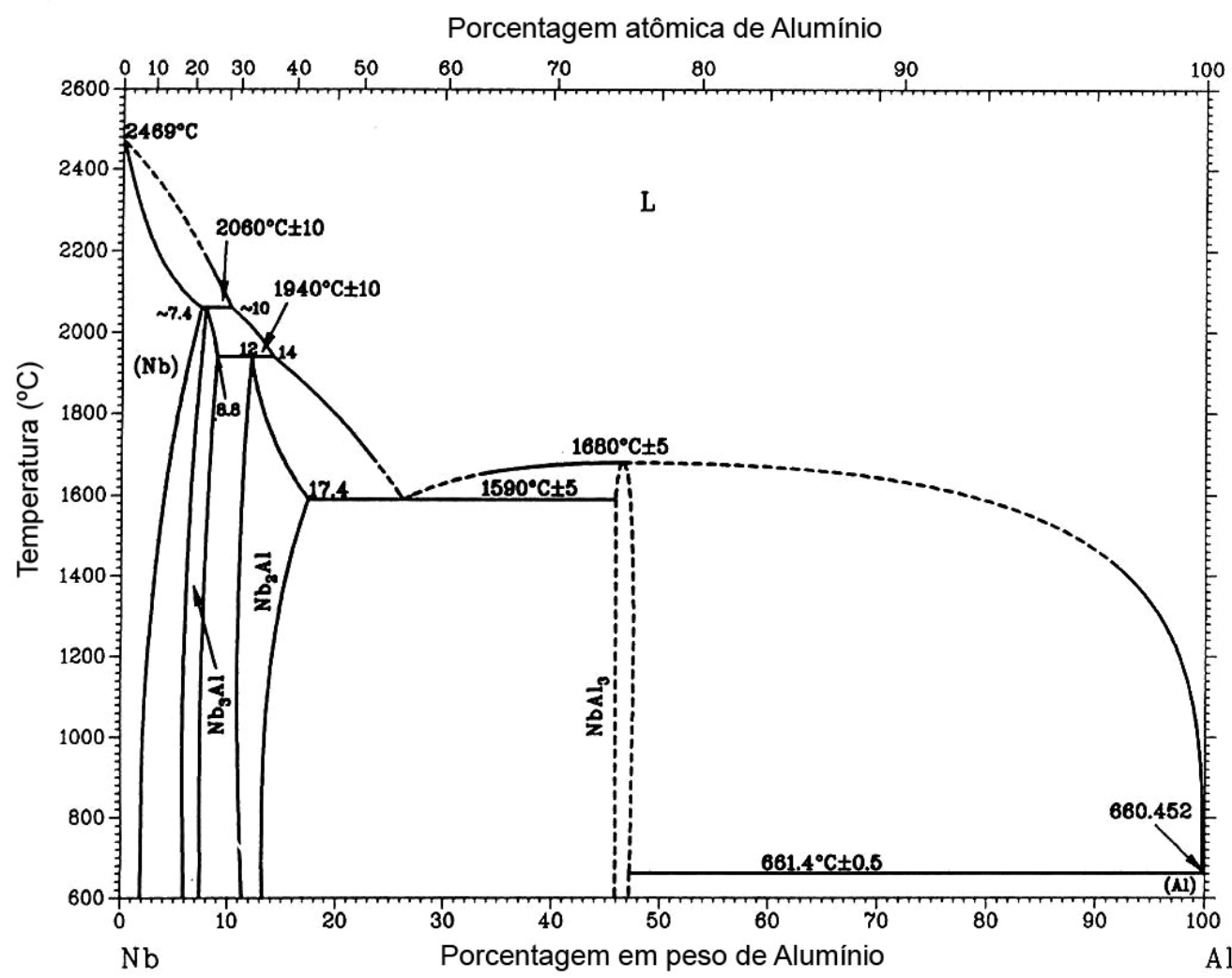

FIGURA 2 - Diagrama de equilíbrio das fases encontradas no sistema Al-Nb (Massalski, 1996). 
Em razão do seu alto teor de alumínio, o $\mathrm{NbAl}_{3}$ foi estudado como camada resistente à oxidação no nióbio e suas ligas (Raisson e Vigne, 1970; Ogurtani, 1972). Entretanto, a ocorrência de um mecanismo de oxidação intergranular acima de $600^{\circ} \mathrm{C}$ degrada substancialmente o composto $\mathrm{NbAl}_{3}$ (Tolpygo e Grabke, 1993). Tal mecanismo pode ser retardado, na faixa entre $600^{\circ} \mathrm{C}$ e $1000^{\circ} \mathrm{C}$, quando existe um excesso de alumínio (Steinhorst e Grabke, 1989). Hayashi e Maruyama (2000) obtiveram sensivel melhora na resistência à oxidação com a adição de magnésio e silício na forma de partículas dispersas de $\mathrm{MgO}$ e $\mathrm{Mg}_{2} \mathrm{Si}$.

\subsection{SÍNTESE POR COMBUSTÃO}

A síntese de uma substância pode ser endotérmica ou exotérmica, dependendo da entalpia de formação do produto. Reações químicas exotérmicas, nas quais pelo menos um dos reagentes está no estado gasoso, são denominadas "combustão", sendo os reagentes que estão no estado sólido ou líquido denominados "combustíveis" e os reagentes no estado gasoso denominados "comburentes". O comburente mais comum é o oxigênio. Numa combustão, a entalpia de reação é negativa e a energia liberada na formação dos produtos aumenta a temperatura local, favorecendo a continuidade do processo de reação, até o consumo completo do combustível ou do comburente. O principal objetivo do processo de combustão é a geração de energia térmica, com posterior conversão para energia mecânica ou elétrica.

Reações químicas exotérmicas em sistemas condensados são comuns durante o processamento químico de diversas substâncias. Entretanto, quando a entalpia de formação é muito negativa, a variação de temperatura pode ser elevada e brusca, dependendo da cinética da reação, dificultando o controle do processo de reação. As reações explosivas são exemplos dessa situação, na qual, além do aumento brusco de temperatura, a formação de produtos gasosos provoca uma expansão volumétrica, com propagação por meio de uma onda de choque.

Essas considerações iniciais visam destacar as semelhanças e diferenças observadas no processo de síntese por combustão em sistemas condensados. 
Esse tipo de reação foi inicialmente denominado "chama sólida" ou "combustão sólida", devido à grande energia liberada na formação do produto e, também, pelo fato dos reagentes permanecerem no estado sólido durante toda a reação (Merzhanov, 1997). Atualmente o termo "síntese por combustão" é empregado para reações altamente exotérmicas com reagentes no estado condensado, assumindo combinações sólido-sólido ou sólido-líquido. Em alguns casos, um dos reagentes pode estar no estado gasoso, porém, o produto de interesse da reação sempre estará no estado condensado.

O mecanismo básico da síntese por combustão consiste no aumento da temperatura local, provocado pelo calor liberado na reação, aumentando a difusividade dos elementos reagentes e a cinética de reação. Esse mecanismo de reação permitiu o desenvolvimento do processo SHS (do inglês: Self-Propagating High Temperature Synthesis) (Merzhanov, 1981), no qual o aquecimento local dos reagentes fornece a energia para iniciar a reação e a energia liberada na reação aumenta a temperatura, gerando um efeito cascata de aquecimento e reação, com propagação auto-sustentável na forma de uma onda de calor. Na FIG.3 é apresentada uma seqüência de quatro imagens ilustrando a síntese por combustão no modo SHS.

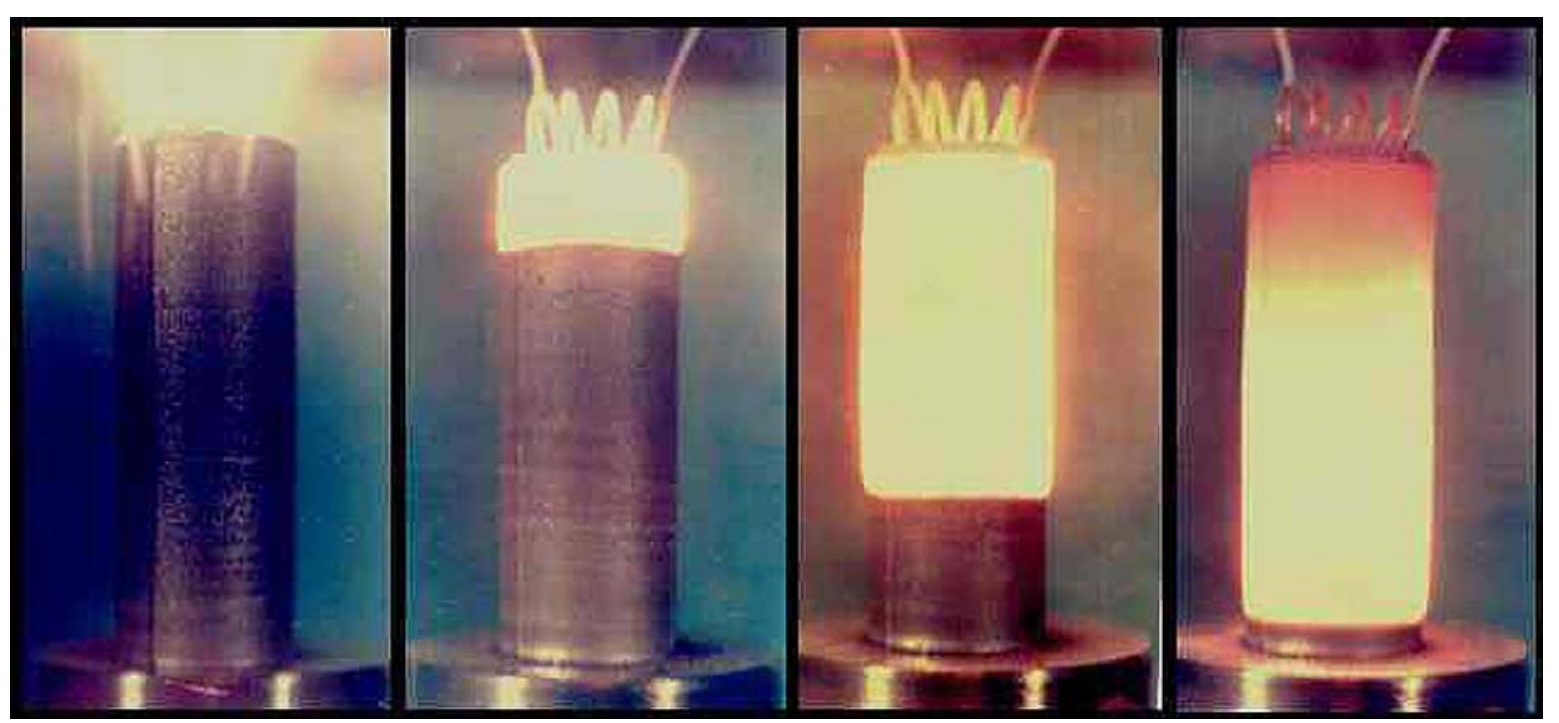

FIGURA 3 - Síntese por combustão no modo SHS de uma mistura compactada de Ti-B. (a) Aquecimento localizado e ignição, $t=0 \mathrm{~s}$; (b) e (c) propagação da frente de reação, $t=1 \mathrm{~s}$ e $t=2,7 \mathrm{~s}$; (d) resfriamento após o término da reação, $\mathrm{t}=4 \mathrm{~s}$ (Merzhanov, 1997). 


\subsubsection{CARACTERÍSTICAS DO PROCESSO}

A primeira etapa no processo de síntese por combustão consiste no aquecimento da mistura de reagentes até a temperatura de ignição. Tal temperatura está relacionada com a quantidade de energia necessária para iniciar e manter a reação exotérmica auto-sustentável. Esse aquecimento pode ser realizado numa pequena região da mistura ou na mistura como um todo. $O$ processo de aquecimento localizado corresponde ao processo SHS, citado acima.

Quando há aquecimento global, o processo é denominado explosão térmica ou combustão simultânea (Munir, 1993, 1988). Nesse caso, a reação é iniciada simultaneamente em diversas partes da mistura.

A opção entre os modos de aquecimento depende basicamente da entalpia de formação do produto. No modo SHS, para que a reação se mantenha autosustentável e se propague ao longo da mistura, a energia liberada na reação de uma determinada unidade de volume deve ser suficiente para aquecer a unidade de volume adjacente até a temperatura de ignição. A dinâmica desse processo é afetada pela distribuição dos reagentes na mistura, pela condutibilidade térmica, pela troca térmica com o meio e pela temperatura inicial dos reagentes (Moore e Feng, 1995a). No modo combustão simultânea, o aquecimento global dos reagentes implica num gasto menor da energia de reação com o aquecimento dos reagentes. A simultaneidade da reação em diversos pontos da amostra e a minimização das perdas térmicas produz taxas de aquecimento da ordem de centenas de graus Celsius por segundo, em toda a amostra. Essa condição otimizada termicamente é utilizada para produtos com baixa entalpia de formação e, também, quando um dos objetivos da síntese por combustão for a densificação do produto. O tempo de permanência do produto a altas temperaturas é maior no modo combustão simultânea, permitindo atingir um grau maior de sinterização (Moore e Feng, 1995a).

Após a ignição da reação de combustão, a taxa de aquecimento cresce muito rápido, até um valor máximo, decrescendo continuamente até atingir a temperatura máxima de reação, também conhecida como temperatura de combustão. O comportamento térmico descrito pode ser diferente se, entre as temperaturas de ignição e de combustão, houver alguma transformação de fase 
nos reagentes ou no produto. No caso hipotético de sistemas adiabáticos, a temperatura de combustão é igual à temperatura adiabática da reação, que pode ser calculada a partir da entalpia de formação e capacidade térmica do produto.

Além das características termodinâmicas dos reagentes e do produto, as variáveis de processo afetam diretamente o comportamento da reação e, particularmente, a densidade do produto final. Existem algumas revisões sobre o assunto disponíveis na literatura (Moore e Feng, 1995a, 1995b; Munir, 1988; Merzhanov, 1981). Algumas das variáveis mais importantes são citadas a seguir:

a. tamanho de partícula: a distribuição de tamanho de partícula dos reagentes apresenta uma grande influência na velocidade de reação. Pós mais finos favorecem a cinética da reação, bem como a obtenção de produtos com estrutura mais refinada (Munir e Anselmi-Tamburini, 1989; Hibino et al., 2001);

b. formação de fase líquida: em uma mistura de dois reagentes sólidos, a formação de fase líquida previamente à reação de síntese ocorre quando um dos reagentes apresenta ponto de fusão inferior à temperatura de ignição, como no caso do $\mathrm{NbAl}_{3}$. A formação desta fase líquida contribui para uma maior densificação do produto final, pois promove um contato mais eficiente entre as partículas dos reagentes, rearranjando-as e favorecendo o contato pela ação da força capilar (Miura et al.,1997; Leal Neto e Ferreira, 1999);

c. taxa de aquecimento: particularmente no modo combustão simultânea, se a velocidade com que os reagentes são aquecidos até a temperatura de ignição for muito baixa, pode ocorrer a formação de produtos por difusão previamente à reação de combustão. Se a taxa de aquecimento for muito alta, pode ocorrer uma diminuição da quantidade de fase líquida formada durante a reação, prejudicando a densificação (Kachelmyer et al., 1995);

d. densidade a verde (antes da reação) do compactado: esta variável pode ser analisada sob dois aspectos: produtos com uma maior densidade inicial apresentam maior condutibilidade térmica durante a reação de síntese, fato que pode ser visto como benéfico à reação. No entanto, se o sistema não for adiabático, as perdas térmicas poderão ser elevadas, provocando uma diminuição da temperatura atingida na combustão. No caso da retirada das 
impurezas voláteis previamente à reação, a densidade a verde do compactado deve ser a menor possível, numa justa medida para conferir certa resistência mecânica, sem prejudicar a saída de gases e impurezas (Kachelmyer et al., 1995; Subrahmanyam e Vijayakumar, 1992);

e. tamanho da amostra: essa variável torna-se particularmente importante para o caso de sistemas não adiabáticos. Amostras de pequenas dimensões apresentam maiores perdas térmicas para o sistema, implicando menores temperaturas de combustão. Por outro lado, amostras de maiores dimensões tendem a aproximar-se da condição adiabática (Munir, 1988);

\subsubsection{CONSIDERAÇÕES TERMODINÂMICAS DO PROCESSO}

A análise do comportamento térmico de uma mistura de reagentes após o início da reação de combustão pode ser conduzida considerando características termodinâmicas e cinéticas da reação química entre os reagentes, e, também, com a avaliação das condições físicas em que a reação se desenvolve (Moore e Feng, 1995b). O grau de complexidade do modelamento teórico aumenta consideravelmente entre a análise termodinâmica e a cinética de reação, haja vista que o comportamento macroscópico da cinética de reação é determinado, em grande parte, pelas condições microscópicas de distribuição e interação dos reagentes. Nessa escala, a reação de combustão em sistemas condensados é considerada intrinsecamente heterogênea (Rogachev et al., 2002), exigindo simplificações quanto às condições de contorno dos equacionamentos, ou realizando modelamentos separados nas escalas micro e macroscópicas (Evstigneev et al., 2007; Ivleva e Merzhanov, 2007).

$\mathrm{Na}$ análise termodinâmica é possível se determinar a temperatura adiabática da reação a partir dos valores de capacidade térmica dos reagentes e dos produtos, bem como das entalpias relativas às transformações de fase que possam ocorrer durante o aquecimento. A análise da variação da entalpia em função da temperatura, tanto para a mistura quanto para o produto, permitem a determinação gráfica da temperatura adiabática. A variação da entalpia da 
mistura durante o aquecimento da temperatura ambiente (298 K) até a temperatura de ignição é dada por (Moore e Feng, 1995a):

$$
\Delta H(R)=\sum_{T_{0}-T_{i g}} n_{i} L\left(R_{i}\right)+\int_{T_{0}}^{T_{i g}} \sum n_{i} C_{p}\left(R_{i}\right) d T
$$

na qual $\boldsymbol{n}_{\boldsymbol{i}}$ é o coeficiente estequiométrico do reagente $\boldsymbol{R}_{\boldsymbol{i}}, \boldsymbol{C p}\left(\boldsymbol{R}_{\boldsymbol{i}}\right)$ é a capacidade térmica e $\boldsymbol{L}\left(\boldsymbol{R}_{\boldsymbol{i}}\right)$ é a entalpia de transformação de fase. Após a formação do produto a variação da entalpia é dada por:

$$
\Delta H(P)=\sum_{T_{i g}-T_{a d}} n_{i} L\left(P_{i}\right)+\int_{T_{i g}}^{T_{a d}} \sum n_{i} C_{p}\left(P_{i}\right) d T
$$

na qual $\boldsymbol{C} \boldsymbol{p}\left(\boldsymbol{P}_{\boldsymbol{i}}\right)$ é a capacidade térmica do produto e $\boldsymbol{L}\left(\boldsymbol{P}_{\boldsymbol{i}}\right)$ é a entalpia de transformação de fase. A FIG.4 apresenta a variação da entalpia calculada para o $\mathrm{NbAl}_{3}$ e para uma mistura Al-Nb, com uma fração molar de alumínio de 0,75. Como os valores de capacidade térmica do $\mathrm{NbAl}_{3}$ não estão disponíveis na literatura, foi utilizada a regra de Neumann-Kopp (Swalin, 1962) para obter uma estimativa a partir das capacidades térmicas dos reagentes (Barin, 1989). A entalpia de formação $\Delta \mathrm{Hf}_{(298)}$ adotada foi $-32,6 \mathrm{~kJ} / \mathrm{mol}$ (Shilo et al., 1982).

No gráfico apresentado na FIG.4 estão indicados os dois modos de síntese por combustão e as respectivas temperaturas adiabáticas atingidas. No modo SHS, a ignição é iniciada com um aquecimento localizado enquanto o restante da mistura está à temperatura ambiente. O calor liberado na reação é usado para aquecer os reagentes na frente de combustão até a temperatura de ignição $(\Delta H(R))$. O excedente de energia é utilizado para aquecer o produto atingindo a temperatura adiabática $(\boldsymbol{H}(\boldsymbol{H}))$. Devido ao grande gasto de energia no aquecimento dos reagentes a temperatura máxima atingida $\left(T_{A D(298)}\right)$ foi de aproximadamente $1308 \mathrm{~K}\left(1035^{\circ} \mathrm{C}\right)$. No modo de combustão simultânea o aquecimento da mistura é realizado por uma fonte externa até a temperatura de ignição $\left(T_{I G}=1153 \mathrm{~K}\right)$. Após iniciada a reação, a energia liberada é integralmente absorvida pelo produto atingindo a temperatura de fusão do $\mathrm{NbAl}_{3}\left(\mathrm{~T}_{\mathrm{AD}(\mathrm{TIG})}\right)$. 


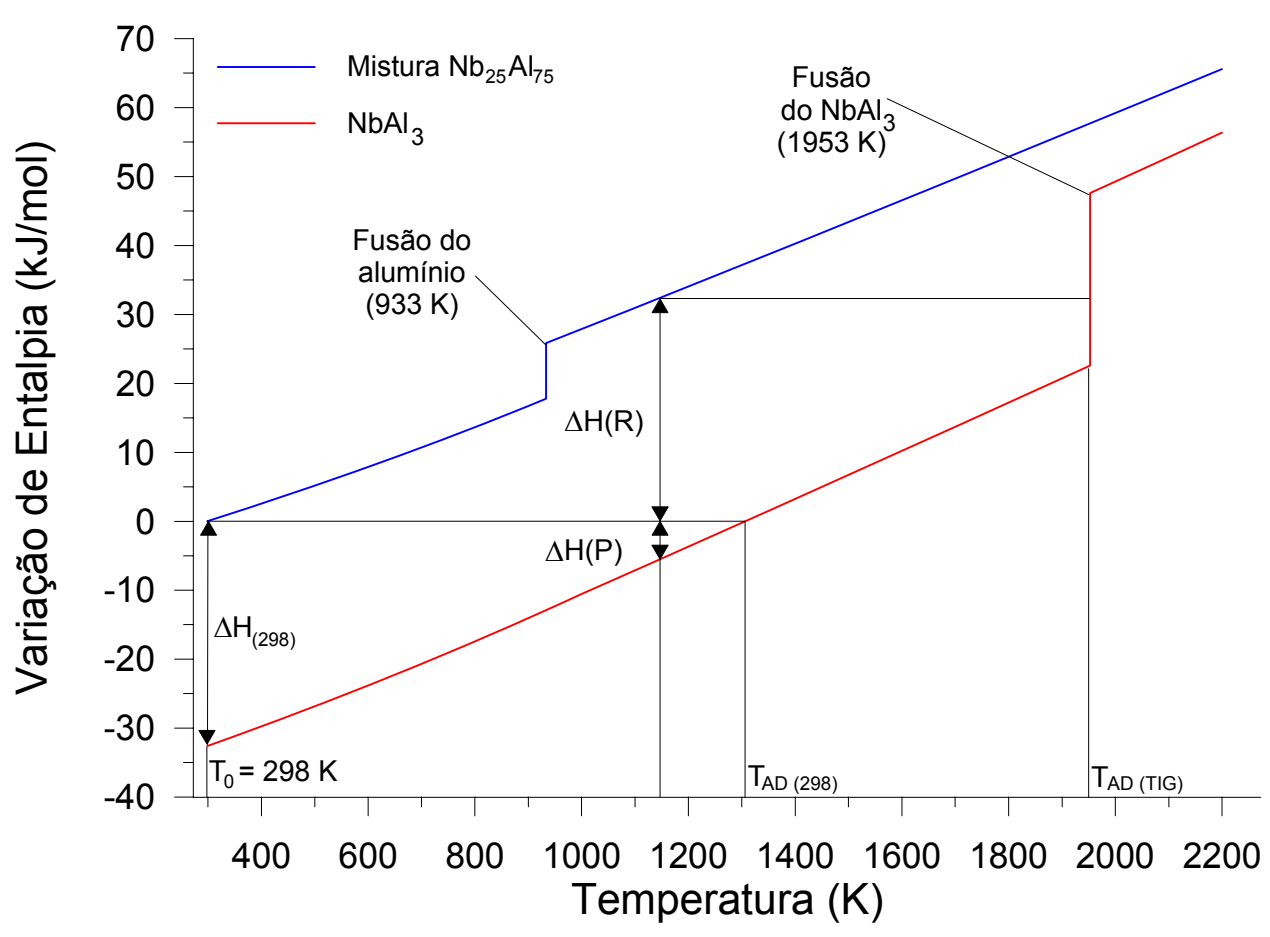

FIGURA 4 - Variação da entalpia da mistura de $\mathrm{Nb}-\mathrm{Al}$ e do intermetálico $\mathrm{NbAl}_{3}$ em função da temperatura, calculada a partir dos dados disponíveis na literatura (Barin, 1989; Shilo et al., 1982).

A determinação da temperatura adiabática é o primeiro passo para a avaliação da auto-sustentabilidade da reação no modo SHS. Dados empíricos (Moore e Feng, 1995a) indicam que a reação só é auto-sustentável se:

$$
\frac{\Delta H_{f}(298)}{C_{p}(298)} \geq 2000 K
$$

No caso de $\mathrm{NbAl}_{3}$, a razão (3) é da ordem de $1200 \mathrm{~K}$, o que indica a necessidade de pré-aquecimento dos reagentes.

Nas últimas duas décadas muitas pesquisas têm sido realizadas no desenvolvimento de técnicas auxiliares que melhorem o desempenho do processo de síntese por combustão. Tais técnicas podem ser agrupadas em três áreas. As duas primeiras utilizam o processo de moagem com alta energia para produzir uma ativação tanto mecânica quanto química. Essa ativação consiste no acúmulo gradual de energia produzida por deformação plástica das partículas da mistura de reagentes, otimizando a taxa de conversão dos reagentes em produto. A primeira área compreende a ativação mecânica e a síntese por combustão "in 
situ", obtendo o produto da reação na forma de pó diretamente do moinho (Takacs et al.,2001; Takacs, 2002). A segunda área compreende as pesquisas que utilizam ativação mecânica na preparação dos pós reagentes e aplicam a síntese por combustão posteriormente (Gauthier et al., 1999; Leal Neto e Rocha, 2001). A terceira área utiliza pressão e passagem de corrente elétrica simultaneamente, provocando o aquecimento rápido da amostra, ignição da reação e manutenção da temperatura pós-reação. Esse sistema pode ou não utilizar reagentes pré-ativados mecanicamente (Munir et al., 2006). O presente trabalho se enquadra na segunda área, sendo que os próximos tópicos desta revisão focarão o processo de moagem com alta energia e seu efeito sobre o processo de síntese por combustão.

\subsection{MOAGEM COM ALTA ENERGIA}

\subsubsection{CARACTERÍSTICAS DO PROCESSO}

A moagem com alta energia de particulados tem sido amplamente utilizada como um processo de síntese ou modificação de propriedades de materiais, no estado sólido. São assim obtidos dispersões ultrafinas (Benjamin, 1970), compostos ou soluções sólidas supersaturadas a partir de pós elementares, além de materiais nanoestruturados e amorfos (Suryanarayana, 2001).

Esse tipo de processo é realizado em moinhos cuja característica básica está na energia cinética e no tipo de movimento das esferas utilizadas na moagem. Nos moinhos de baixa energia convencionais, a energia cinética das esferas é proporcional à massa e à altura de queda livre. As partículas presentes na área de choque sofrem uma deformação absorvendo parte dessa energia e podendo chegar à fratura. Nos moinhos de alta energia é aplicada uma aceleração às esferas muito maior que a da gravidade, aumentando consideravelmente a energia cinética.

Quando submetidas à moagem com alta energia, as partículas sofrem sucessivos ciclos de deformação, promovendo a soldagem entre si ou a fratura (Benjamin e Volin, 1974). Para materiais frágeis, o evento de fratura das 
partículas é mais freqüente, diminuindo do tamanho de partícula e aumentando a área de superfície. No caso de materiais dúcteis, a deformação plástica aumenta a probabilidade de soldagem entre partículas, situação que favorece o aumento do tamanho de partícula.

Benjamin e Volin (1974) identificaram quatro fases no processo de moagem de misturas de materiais dúcteis. Na fase inicial, as partículas são deformadas plasticamente, assumindo uma forma achatada. A intensidade dessa alteração de forma depende da ductilidade do material e da energia de impacto das esferas de moagem. $O$ aumento da área de superfície aumenta progressivamente a probabilidade de soldagem a frio dessas partículas, acarretando um aumento do tamanho médio de partícula. A segunda fase é caracterizada pela predominância do evento de soldagem entre partículas. Considerando a moagem de uma mistura, na segunda fase ocorre a formação de partículas compostas, denominadas aqui de agregados, com uma distribuição simples dos materiais que constituem a mistura e com composição química heterogênea.

O acúmulo de deformação plástica acarreta um aumento do encruamento e da resistência mecânica das partículas. Essa situação aumenta a probabilidade de fratura das partículas ou agregados. Na terceira fase, a equalização dos eventos de fratura e de soldagem modifica a dispersão nos agregados, homogeneizando-os quimicamente. A quarta fase é caracterizada pelo refinamento da microestrutura desses agregados. A FIG.5 apresenta esquematicamente as principais fases do processo de moagem de misturas dúcteis.

A moagem com alta energia pode ser realizada em diferentes tipos de moinhos e esta é umas das variáveis mais importantes na comparação de resultados de diferentes pesquisas. O moinho mais utilizado é do tipo agitador, marca Spex®. Esse moinho é indicado para processamento de pequenas quantidades de material, situação comum em laboratórios de pesquisa. Outro moinho muito utilizado nos últimos anos é o moinho tipo planetário. Além de uma capacidade de processamento maior, o moinho planetário possibilita o controle sobre o nível de energia de moagem. Entretanto, esses moinhos têm um caráter mais complementar do que competitivo, já que a dinâmica de moagem é muito diferente em cada um. 


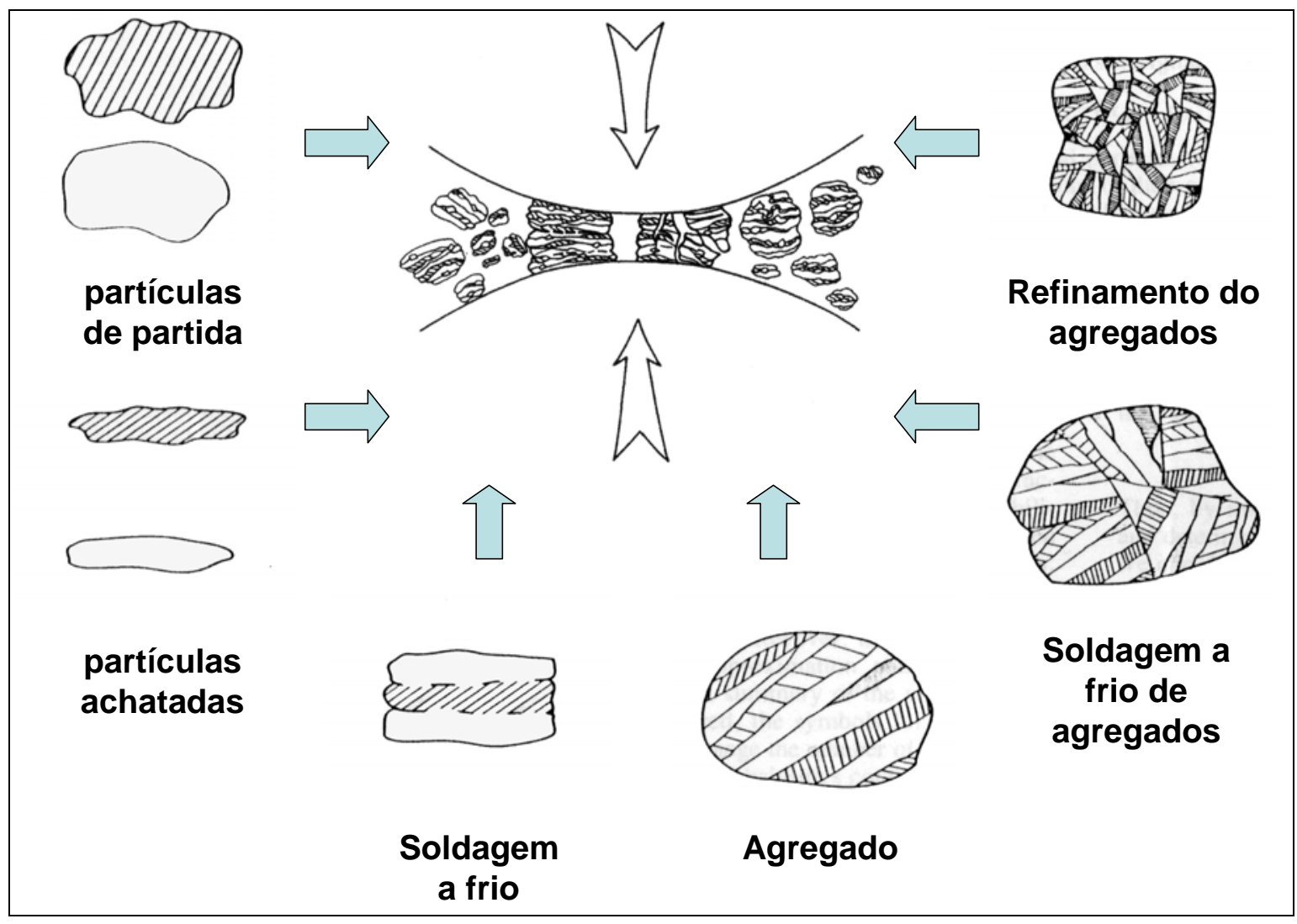

FIGURA 5 - Seqüência esquemática de eventos durante a moagem com alta energia de misturas dúcteis (Benjamin e Volin, 1974).

Diversas pesquisas têm sido desenvolvidas com o intuito de qualificar e quantificar o processo de moagem com alta energia. Assim como no caso da síntese por combustão, as estratégias de modelamento concentram-se na dinâmica dos elementos da moagem (copo, esferas e partículas) e no processo de interação entre as partículas em condições transientes de pressão e temperaturas elevadas (Cocco et al.,2000). Algumas investigações qualitativas sobre a eficiência desses moinhos utilizam como referência o comportamento térmico do processo de síntese por combustão (Rocha et al., 2006; Takacs e Sepelak, 2004).

Existem boas compilações disponíveis sobre moagem com alta energia (Takacs, 2002; Suryanarayana, 2001; Lai e Lu, 1998). Algumas das principais variáveis apontadas para esse processo e que são comuns nos diversos tipos de moinhos, são apresentadas a seguir:

a. Tempo de moagem. Apresentada como a principal variável, o tempo de moagem é diretamente proporcional à energia transferida ao pó. Diversas 
variáveis dependem diretamente do tempo de moagem, dentre elas, a distribuição granulométrica, a forma das partículas e a microestrutura dos agregados, no caso de misturas;

b. Distribuição de tamanho e densidade das esferas de moagem. A energia transferida a um conjunto de partículas durante um evento de colisão é diretamente proporcional à massa das esferas de moagem. $\mathrm{O}$ aumento no diâmetro e/ou na densidade das esferas implica uma maior energia disponível por impacto, afetando a pressão nas interfaces e a temperatura instantânea que o conjunto de partículas pode atingir durante uma colisão;

c. Velocidade do meio de moagem. O controle da energia cinética das esferas depende do tipo de moinho utilizado. Nos moinhos agitadores Spex®, a freqüência e a amplitude de agitação são fixas, o que impede o controle da velocidade das esferas. No caso do moinho planetário, a velocidade de translação do copo pode ser alterada, possibilitando a variação de energia;

d. Razão esfera-pó. A proporção em massa entre as esferas e o pó é considerada importante na determinação da intensidade de moagem. A energia transferida ao pó durante uma colisão acarreta conseqüências diferentes dependendo do volume de pó confinado à área de colisão. Quanto menor a razão esfera-pó, maior será o volume de partículas que absorverão a energia de impacto, diminuindo assim a energia transferida por unidade de volume;

e. Grau de preenchimento do copo. A eficiência do processo de moagem depende do equilíbrio entre quantidade de esferas e o grau de liberdade de movimento destas dentro do copo de moagem;

f. Agente controlador de processo (ACP). O sucesso da moagem com alta energia está diretamente ligado ao balanço entre os eventos de fratura e soldagem que ocorrem durante as colisões. Dependendo das características físico-químicas e mecânicas das partículas pode haver um excesso de eventos de soldagem, acarretando um significativo aumento de seu tamanho. Nesses casos, pequenas adições de substâncias orgânicas com o intuito de 
controlar a soldagem entre partículas. Esta variável também afeta diretamente a cinética de moagem;

g. Freqüência de colisões. A cinética de moagem é determinada pelas variáveis apresentadas acima combinadas com o número de colisões por segundo proporcionado pelo sistema de moagem. A freqüência de colisões é diretamente proporcional ao número e à velocidade das esferas;

h. Temperatura de moagem. A temperatura de moagem afeta diretamente as propriedades físicas e mecânicas do material sendo processado. A moagem criogênica, por exemplo, pode produzir materiais ultrafinos e amorfos devido à limitação de ductilidade. O aquecimento durante a moagem devido às condições de moagem e ao tipo de moinho pode atingir temperaturas da ordem de $200^{\circ} \mathrm{C}$, sendo que temperaturas mais altas facilitam o processo de síntese de ligas durante a moagem;

i. Atmosfera de moagem. A escolha do tipo de atmosfera depende do objetivo da moagem. De uma maneira geral se utilizam gases inertes para evitar reações gás-metal indesejáveis. Entretanto, pode-se utilizar nitrogênio ou hidrogênio quando o objetivo é formar nitretos ou hidretos durante a moagem.

\subsubsection{ATIVAÇÃO MECÂNICA NA MOAGEM COM ALTA ENERGIA}

O termo "ativação mecânica" é empregado em situações nas quais o processamento mecânico modifica as características do material quanto à sua reatividade, ou seja, reduzindo a energia de ativação para iniciar uma reação química (Boldyrev, 1998; Gaffet et al.,1994). Esse termo foi utilizado pela primeira vez por Shaw (1948) para designar a otimização de reações entre compostos orgânicos e metais a partir de materiais obtidos durante processos de usinagem.

A extensão dos efeitos da ativação mecânica sobre um sistema particulado monofásico ou polifásico (misturas), depende das características físicas e químicas de seus componentes. No caso de sistemas frágeis, a limitada capacidade de deformação plástica induz a fratura das partículas, aumentando a 
área de superfície específica. Em materiais iônicos e covalentes, esse aumento da área de superfície é acompanhado de um incremento das tensões elásticas e de defeitos estruturais e eletrônicos, alterando a reatividade e a energia interna (Steinike e Tkacova, 2000). Em sistemas dúcteis, a densidade de defeitos cristalinos aumenta devido à deformação plástica intensa. Embora a redução de tamanho de partícula não seja tão eficiente em sistemas dúcteis quanto o observado em sistemas frágeis, é possível obter acentuadas reduções no tamanho de cristalito, formando materiais nanocristalinos, que possuem notadamente propriedades químicas, físicas e mecânicas diferenciadas (Suryanarayana e Koch, 2000).

A ativação mecânica de misturas promove alterações microestruturais complementares às citadas acima. Numa mistura de materiais particulados uma fração da área de superfície das partículas corresponde à superfície de contato entre partículas dissimilares. Essa área de interface depende da área de superfície específica e fração volumétrica de cada componente da mistura, da homogeneidade de dispersão dos componentes e do grau de empacotamento das partículas após o processo de conformação da mistura. Durante a moagem com alta energia, a formação de agregados de partículas dissimilares aumenta consideravelmente a área de interface. Dependendo do grau de interação entre os componentes da mistura, o refino da microestrutura desses agregados pode produzir nanocompósitos ou a síntese de uma nova fase.

A síntese de materiais durante a moagem com alta energia pode ocorrer por uma reação de combustão durante a moagem (Takacs, 2002) ou pelo refino contínuo da microestrutura de agregados dos componentes da mistura (Fernandes et al., 2007). A formação de interface possibilita a ocorrência de interações químicas entre os componentes da mistura. Os tipos de interações possíveis, bem como suas intensidades, dependem das condições termodinâmicas locais. Essas condições são alteradas constantemente durante a moagem devido às variações de pressão e temperatura na região de colisão das esferas. A formação de soluções sólidas durante a moagem indica que a difusão de elementos através da interface é um mecanismo ativo. Apesar das moagens serem realizadas à temperatura ambiente, os picos de temperatura num impacto frontal entre duas esferas pode chegar a centenas de graus Celsius, dependendo 
das condições de moagem. Entretanto, as condições que viabilizam o processo de difusão durante a moagem ainda estão em discussão.

Schwarz (1998) propôs um modelo microscópico para o mecanismo de formação de ligas por ação mecânica ("Mechanical Alloying”) que ocorre durante a moagem com alta energia de diversos sistemas dúcteis. Esse mecanismo se baseia no fato da difusão de solutos substitucionais, a temperaturas próximas à ambiente, ocorrer essencialmente pelas discordâncias e pelos contornos de grão. O ponto de partida do modelo é a formação de uma interface entre dois componentes da mistura, que permita a interação química entre os diferentes átomos. Como descrito anteriormente, essa interface se forma durante o impacto entre os elementos de moagem, simultaneamente a certa quantidade de deformação plástica dos componentes. A existência de discordâncias junto à interface permite que haja a interação entre tais discordâncias e os átomos de soluto. Essa interação é mais forte quanto maior for a diferença de volume atômico entre os átomos de soluto e de solvente. A difusividade do soluto junto às discordâncias dependerá do grau de distorção da estrutura cristalina e do volume do átomo de soluto, sendo que átomos menores que o solvente tendem a difundir mais lentamente. A extensão da penetração do soluto na estrutura do solvente dependerá da difusividade e do tempo de imobilidade da discordância, também denominado tempo de descanso. Esse tempo está relacionado com as condições de moagem, particularmente com a freqüência de colisões, ou seja, quanto menor for a freqüência de colisões, maior será o tempo entre duas colisões envolvendo a mesma interface. O autor do modelo estimou essa extensão em aproximadamente $91 \mathrm{~nm}$ para a difusão de zinco, numa matriz de cobre e um tempo de imobilidade de $100 \mathrm{~s}$. Entretanto, Estrin e Rabkin (1998) pontuaram que essa extensão pode ser maior, devido ao efeito de aumento da difusividade provocado pela curvatura da discordância. O mecanismo completa um ciclo quando a interface em questão participa de outra colisão. Nesse momento, o estado de tensão criado na colisão provoca a movimentação das discordâncias, desvinculando a discordância e os átomos de soluto, criando condições de difusão junto à interface, novamente.

O mecanismo descrito acima promove a formação de uma solução sólida junto à interface, que pode ser supersaturada ou não. No caso de volumes 
atômicos semelhantes, a difusão pode ocorrer nos dois lados da interface, caso contrário, a difusão será maior no lado da interface correspondente ao menor volume atômico.

Alguns pesquisadores ponderam variações conceituais sobre o mecanismo de formação de solução sólida e o papel da difusão nesse processo. Em todas as ponderações pesquisadas uma das principais diferenças em relação ao modelo apresentado por Schwarz (1998) diz respeito ao mecanismo de formação de solução sólida estar restrito ao momento da colisão. Skakov (2004) considera que a difusão de soluto ocorre pelo mecanismo denominado "Crowdion", que consiste na redução do espaçamento atômico em determinadas direções cristalográficas pela introdução, por ação mecânica, de átomos de soluto, formando assim uma solução intersticial de átomos que normalmente ocupam uma posição substitucional. Esse mecanismo ainda é questionado e a possibilidade termodinâmica de sua ocorrência parece estar restrita a condições muito distantes do equilíbrio. Shtremel (2002) considera que a difusão na moagem com alta energia não é significativa até que se atinja uma escala nanométrica, sendo que o mecanismo predominante na maior parte do processo é a mistura mecânica por cisalhamento das fases, sendo que a formação da solução sólida pode ocorrer somente se houver condições termodinâmicas locais para tal. Farber (2002) pondera que a intensa deformação plástica sob condições de altas tensões potencializa a formação de lacunas associadas com a movimentação das discordâncias, o que possibilitaria o processo de difusão substitucional.

\subsubsection{SÍNTESE POR COMBUSTÃO DE $\mathrm{NbAl}_{3}$ COM E SEM ATIVAÇÃO MECÂNICA}

A síntese de $\mathrm{NbAl}_{3}$, utilizando o modo de combustão simultânea e visando a densificação do produto, foi pesquisada sistematicamente por Murray e German (1992). O processo foi denominado de sinterização reativa, devido à utilização de um patamar de sinterização em alta temperatura. Investigou-se a distribuição granulométrica dos reagentes, a taxa de aquecimento e a temperatura de sinterização. Os autores observaram que a relação de 1:3 entre os tamanhos 
médios de partícula de nióbio e alumínio produziu a melhor densificação, após o processo de sinterização reativa. Essa distribuição granulométrica associada a uma taxa de aquecimento de $15^{\circ} \mathrm{C} / \mathrm{min}$ e uma temperatura de sinterização de $1200^{\circ} \mathrm{C}$ produziram pastilhas com $95 \%$ da densidade teórica. A aplicação de pressão durante a sinterização possibilitou alcançar valores maiores que $98 \%$ da densidade teórica. O emprego de taxas de aquecimento maiores acarretava a perda de forma da pastilha, devido ao excesso de líquido formado durante a reação.

Kachelmyer et al. (1995) estudaram especificamente a síntese do intermetálico $\mathrm{NbAl}_{3}$ utilizando reação de combustão simultânea, sem o emprego de patamar de sinterização. A monitoração da temperatura da amostra permitiu identificar os principais estágios da etapa de aquecimento e da reação de combustão simultânea, entretanto, não foram apresentados perfis de temperatura experimentais. A FIG.6 apresenta um perfil térmico esquemático e suas principais características. A investigação do efeito da taxa de aquecimento e da densidade a verde sobre o comportamento térmico e a microestrutura do produto final mostrou que a ignição da reação ocorreu apenas para taxas de aquecimento iguais ou superiores a $20^{\circ} \mathrm{C} / \mathrm{min}$ e que a reação só foi completa para densidades a verde acima de $66 \%$ da densidade teórica. A temperatura de ignição foi de aproximadamente $880^{\circ} \mathrm{C}$, com pouca variação entre as condições avaliadas. A temperatura máxima de reação atingiu o valor de $1680^{\circ} \mathrm{C}$, ou seja, a temperatura de fusão do $\mathrm{NbAl}_{3}$. Constatou-se ainda que o alumínio não molhou a superfície do nióbio até a temperatura de ignição, fenômeno também observado por Leal Neto e Ferreira (1999). Essa falta de molhabilidade gera forças de repulsão entre partículas, provocando o inchamento da pastilha e até a exudação de alumínio líquido na superfície da pastilha. A presença de óxido de alumínio junto à interface $\mathrm{Al}-\mathrm{Nb}$ é um dos motivos para essa falta de molhabilidade e o retardamento no processo de formação de $\mathrm{NbAl}_{3}$ (Barmak et al., 1990; Lu et al., 1991). O fenômeno de ignição pode estar associado à diminuição da estabilidade química ou mecânica dessa camada de óxidos permitindo a formação de $\mathrm{NbAl}_{3}$ e a melhoria das condições de molhabilidade. O aumento da molhabilidade gera forças de atração entre as partículas, e o fenômeno de capilaridade promove a absorção do alumínio que tiver sido exudado. 


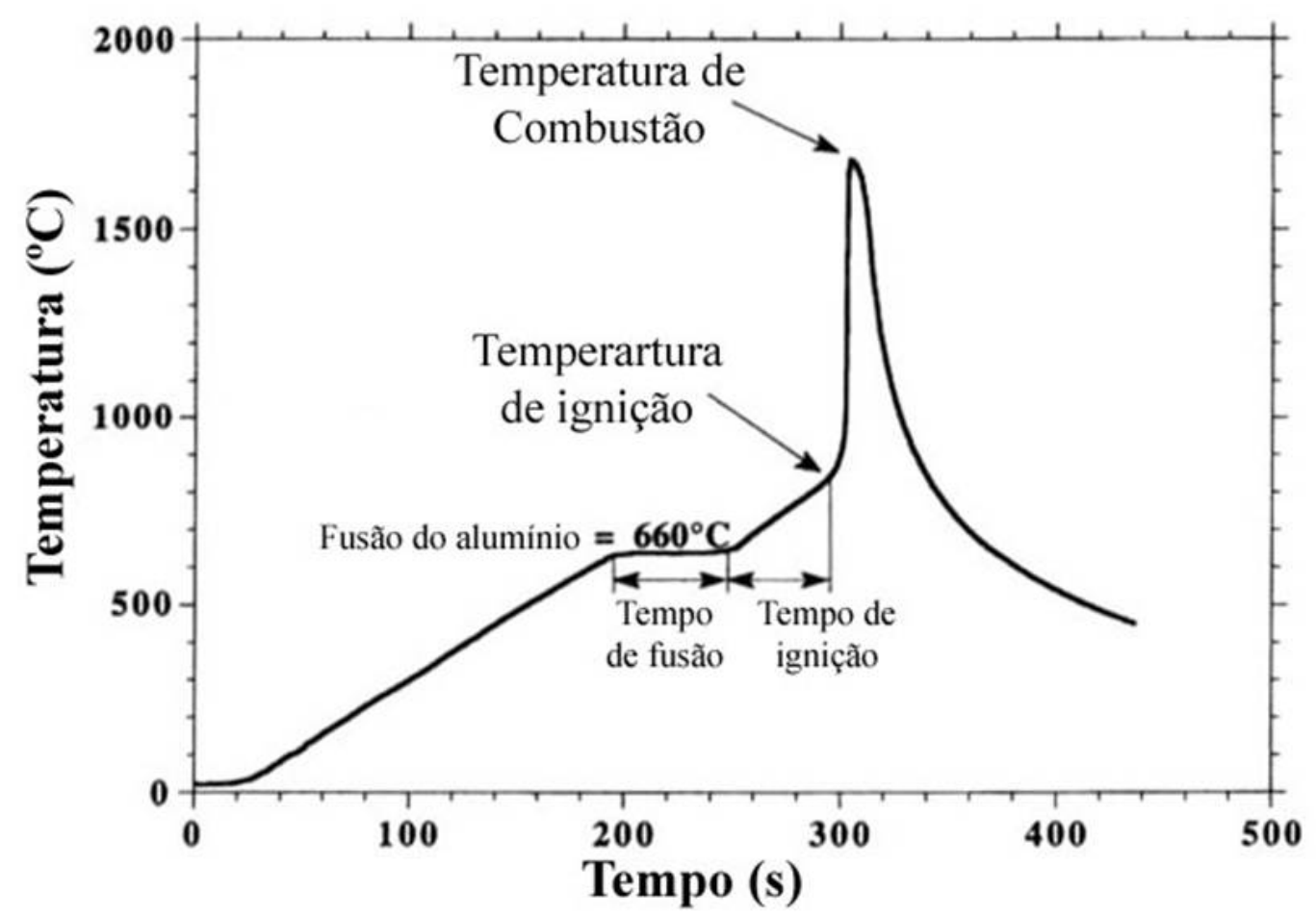

FIGURA 6 - Perfil esquemático da variação da temperatura de uma amostra do sistema Al-Nb submetida a um ciclo térmico de reação de combustão simultânea (Kachelmyer et al., 1995).

Do ponto de vista microestrutural o processo de formação do intermetálico $\mathrm{NbAl}_{3}$ durante a síntese por reação, apresentado por Ferreira e Leal Neto (1994), consiste na dissolução de nióbio no alumínio líquido seguido da precipitação de $\mathrm{NbAl}_{3}$ junto à interface das partículas de nióbio. Esse mecanismo se mantém ativo enquanto existir interfaces do nióbio sólido e alumínio líquido. Entretanto, para temperaturas abaixo de $1000^{\circ} \mathrm{C}$, a solubilidade de nióbio no alumínio líquido é relativamente baixa, o que leva à formação de uma camada fina de $\mathrm{NbAl}_{3}$ na superfície do nióbio. O aumento da espessura dessa camada ocorre pela difusão de alumínio pela estrutura do $\mathrm{NbAl}_{3}$ (Slagma e Vignes, 1972). A cinética desse processo depende da quantidade de fase líquida, do grau de dispersão dos reagentes e da temperatura, a qual afeta diretamente a difusividade do nióbio na fase líquida e a difusividade do alumínio no intermetálico $\mathrm{NbAl}_{3}$. 
A síntese por combustão do $\mathrm{NbAl}_{3}$ no modo $\mathrm{SHS}$ foi investigada por Maslov et al. (1979) e Leal Neto e Ferreira (1999), sendo que as duas investigações foram complementares entre si. O primeiro autor investigou o efeito da quantidade de alumínio ( $20 \%$ a $80 \%$ ) sobre o comportamento térmico da propagação da frente de reação, obtendo os valores máximos para a composição relativa ao $\mathrm{NbAl}_{3}$. A temperatura máxima de reação obtida foi de $1650^{\circ} \mathrm{C}$ e a velocidade de propagação de $1,2 \mathrm{~cm} / \mathrm{s}$. Um ponto a destacar é a temperatura de pré-aquecimento dos reagentes, fixada em $850^{\circ} \mathrm{C}$.

Leal Neto e Ferreira (1999) focaram a investigação na avaliação da dinâmica microestrutural da reação. Para tanto, as amostras não foram préaquecidas e após a ignição da reação em uma das extremidades, a baixa exotermia da reação e o grande consumo de energia na fusão do alumínio foram suficientes para extinguir o processo de reação naturalmente. A análise das várias regiões da amostra (antes, durante e após a reação) mostrou uma forte e heterogênea movimentação do alumínio líquido na frente da reação. A grande quantidade de fase líquida, característica dessa composição, e as altas temperaturas de ignição, mostraram ser fatores determinantes na heterogeneidade microestrutural da frente de reação.

A utilização de moagem com alta energia na síntese de compostos do sistema Al-Nb, foi inicialmente realizada por Hellstern e Schultz (1988), cujo objetivo foi verificar a possibilidade de estender os limites de solubilidade e de amorfisação. Constatou-se que a fase amorfa só foi obtida na composição equiatômica. No caso de composições com maior teor de nióbio, observou-se uma extensão do limite de solubilidade do alumínio, na estrutura A2 do nióbio, para $40 \%$ atômico. A formação dos compostos foi obtida com tratamento térmico posterior à moagem observando uma extensão da faixa de composição onde o $\mathrm{NbAl}_{3}$ se mantêm estável. Suryanarayana et al. (1994) observaram a formação de $\mathrm{NbAl}_{3}$ após dez horas de moagem, em moinho tipo Spex® e uma completa amorfisação após quarenta horas de moagem. Embora o tempo de moagem tenha sido menor que o utilizado na primeira pesquisa (60 horas), a diferença de resultados está relacionada com as diferentes condições de moagem já que, na primeira pesquisa, foi utilizado um moinho planetário. 
Alguns pesquisadores franceses (V. Gauthier, F. Bernard, E. Gaffet, C. Josse, J.P. Larpin, D. Vrel, M. Gailhanou, N. Malhouroux-Gaffet, C. Gras, J.C. Niepce) publicaram, conjuntamente, vários resultados sobre a utilização da moagem com alta energia combinada com a técnica de síntese por combustão no modo SHS, ou com tratamentos de recozimento. Os procedimentos utilizados foram denominados de MASHS (do inglês: "mechanically activated selfpropagating high-temperature synthesis") e M2AP (do inglês: "mechanically activated annealing process"). A primeira etapa dos procedimentos mencionados acima é a mesma e consiste na ativação mecânica dos reagentes em moinho de alta energia, por um curto período de tempo. Essa limitação no tempo de moagem tem como objetivo minimizar a reação entre os reagentes durante a moagem (Malhouroux-Gaffet e Gaffet, 1993). No procedimento MASHS a segunda etapa consiste num processo convencional de síntese por combustão, no modo SHS, dos reagentes ativados mecanicamente. No caso do M2AP, os reagentes ativados são submetidos a um tratamento de recozimento para a formação do produto por difusão no estado sólido.

A aplicação desses procedimentos na síntese de $\mathrm{NbAl}_{3}$ mostrou que, em ambos, foi possível a obtenção do intermetálico em questão (Gauthier et al., 1999, 2002). Entretanto, a densidade obtida na síntese por SHS foi relativamente baixa (50\% a $60 \%$ da densidade teórica). Um resultado que deve ser ressaltado é a auto-sustentabilidade da propagação da reação, situação observada anteriormente somente com o pré-aquecimento da mistura (Maslov et al.,1979). Apesar dos autores não mencionarem claramente o gradiente térmico das amostras no momento da ignição, o tamanho das amostras utilizadas e os tempos de aquecimento apresentados nos perfis térmicos, sugerem que a extremidade oposta à de início do processo de síntese poderia estar a uma temperatura acima da temperatura ambiente, situação que facilitaria a propagação da reação. O efeito da ativação mecânica sobre a temperatura de ignição não ficou claro porque, no primeiro trabalho, essa temperatura foi muito menor do que a da amostra sem ativação e, no segundo, praticamente não houve diferença.

A argumentação dos autores sobre o mecanismo microestrutural responsável pela ativação mecânica pondera que a moagem com alta energia promove um refinamento na distribuição dos reagentes, diminuindo as distâncias 
de difusão, afetando diretamente a cinética da reação. A expressão utilizada para caracterizar esse refinamento microestrutural diz que a moagem com alta energia promove a formação de "poli-interfaces tridimensionais em escala nanométrica". Embora não esteja claro o significado dessa expressão, há uma possibilidade de estar relacionada com a formação de agregados com microestrutura fina, o que caracterizaria a quarta fase do processo de moagem com alta energia apresentada por Benjamin e Volin (1974).

O grupo de pesquisadores brasileiros, do qual o presente autor faz parte (R.M. Leal Neto, C.J. Rocha, V.S. Gonçalves), publicou vários resultados sobre o efeito da moagem com alta energia sobre a síntese por combustão simultânea do $\mathrm{NbAl}_{3}$, os quais são sumarizados a seguir:

a. A ativação mecânica diminui a temperatura de ignição das misturas de $\mathrm{Nb}-\mathrm{Al}$ com $75 \%$ atômico de alumínio (Leal Neto e Rocha, 2001; Leal Neto et al., 2003);

b. O processo de densificação durante a síntese por combustão simultânea, sem aplicação de pressão, é afetado pelo tempo de moagem e pela quantidade de agente controlador de processo (ACP) adicionado à mistura (Rocha et al., 2003; Leal Neto et al., 2003);

c. A utilização de ACP minimiza a aderência das partículas nas paredes do copo e das esferas e retarda a formação de agregados de alumínio e nióbio (Rocha et al., 2003).

d. O tipo de moinho utilizado afeta diretamente a cinética de formação e a forma dos agregados Al-Nb. A diferença é mais intensa para tempos curtos de moagem (Rocha et al.,2006);

e. A temperatura máxima de reação diminui com o tempo de moagem (Rocha et al.,2006).

O efeito do tempo de moagem com alta energia no comportamento térmico da mistura $\mathrm{Nb}_{25} \mathrm{Al}_{75}$ e sua relação com a microestrutura dos agregados, estão apresentados na FIG.7. O refinamento da estrutura lamelar dos agregados com o tempo de moagem acarreta um aumento da área de interface entre os reagentes e, provavelmente, um melhor contato entre os reagentes na interface. 

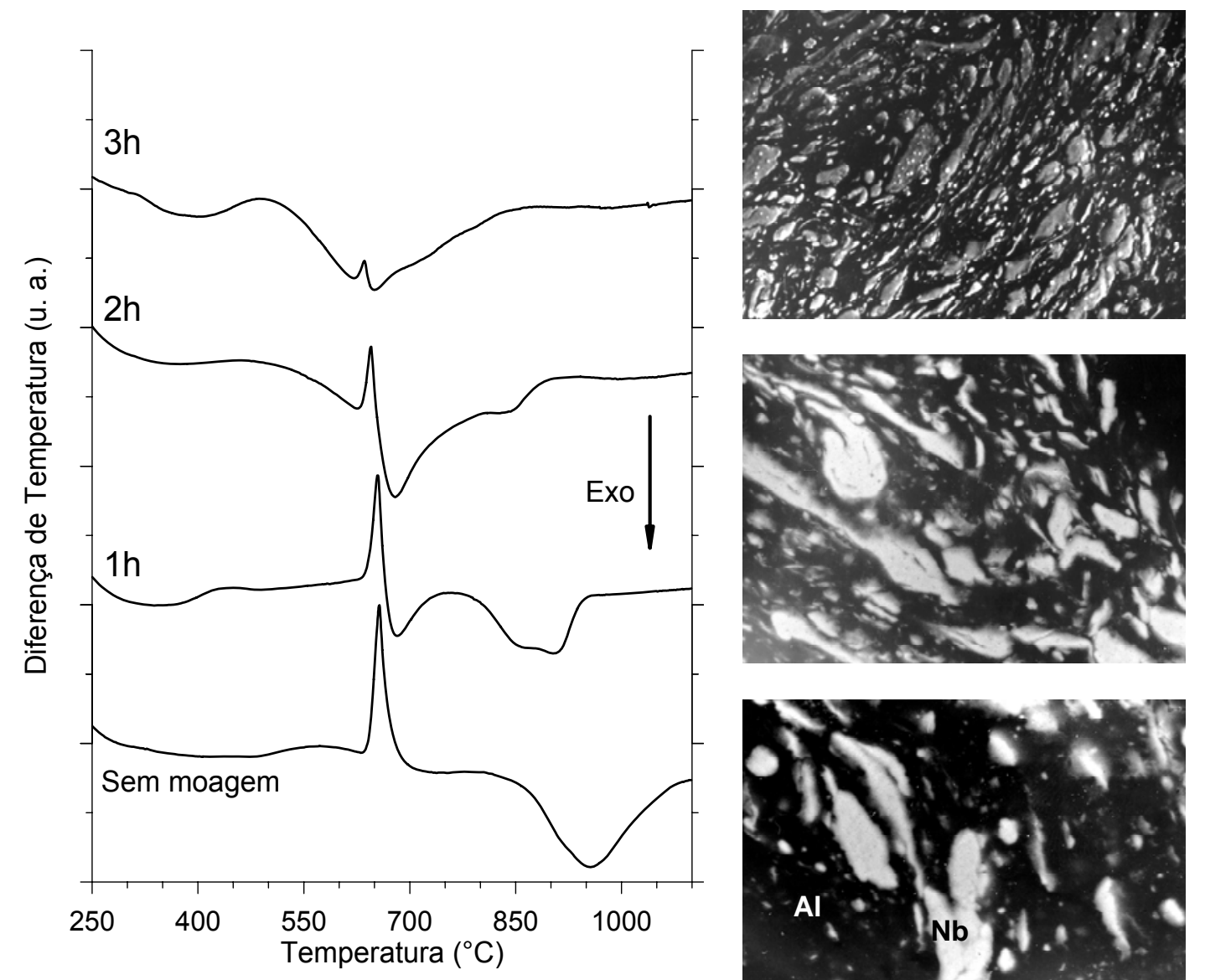

$3 \mathrm{~h}$

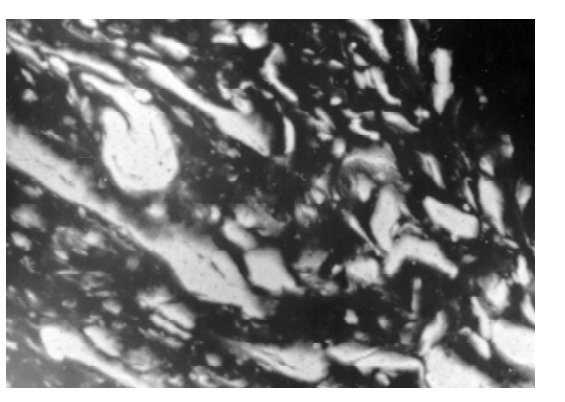

$2 \mathrm{~h}$

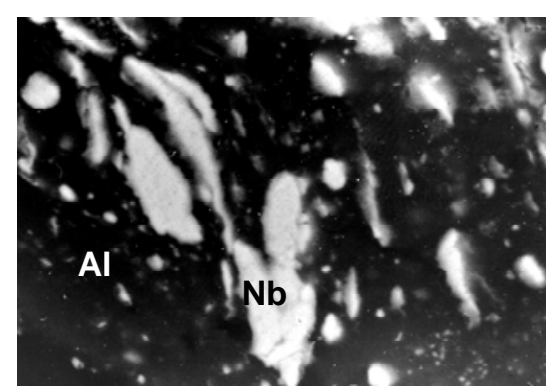

$1 \mathrm{~h}$

FIGURA 7 - Efeito do tempo de moagem com alta energia no comportamento térmico e na microestrutura dos agregados de misturas $\mathrm{Nb}_{25} \mathrm{Al}_{75}$ (Leal Neto e Rocha, 2001).

Vários trabalhos foram publicados utilizando a técnica de filmes finos na tentativa de elucidar os mecanismos de reação junto à interface Al-Nb. Lucadamo et al. (2001) avaliaram o efeito da periodicidade das camadas de alumínio e nióbio no processo de formação de $\mathrm{NbAl}_{3}$, concluindo, a partir de dados de análise térmica, que a diminuição da espessura das camadas reduziu a temperatura de formação do intermetálico da faixa entre $550^{\circ} \mathrm{C}$ e $650{ }^{\circ} \mathrm{C}$, no caso de uma periodicidade de $333 \mathrm{~nm}$, para em torno de $340^{\circ} \mathrm{C}$ quando a periodicidade foi reduzida para $10 \mathrm{~nm}$. Além disso, observou-se que a formação do intermetálico ocorre em duas etapas, sendo a primeira pela nucleação e crescimento de uma camada de $6 \mathrm{~nm}$ a $10 \mathrm{~nm}$ de espessura de $\mathrm{NbAl}_{3}$ ao longo da interface $\mathrm{Al}-\mathrm{Nb}$. A segunda etapa inicia-se após o consumo total da interface $\mathrm{Al}-\mathrm{Nb}$, consistindo-se num crescimento da camada de $\mathrm{NbAl}_{3}$ no sentido 
perpendicular a antiga interface Al-Nb. Entretanto, essa última etapa necessita de uma ativação térmica maior.

Os estudos utilizando a técnica de filmes finos revelam que a formação de $\mathrm{NbAl}_{3}$ ocorre antes da fusão do alumínio, ou seja, por difusão no estado sólido. Embora, a solubilidade do alumínio no nióbio seja maior do que a condição inversa, as micrografias feitas por microscopia eletrônica de transmissão apresentadas por Lucadamo et al. (2001) mostram que o $\mathrm{NbAl}_{3}$ forma-se por difusão do nióbio no alumínio. Essa constatação experimental pode ser utilizada para dar suporte ao modelo microscópico proposto por Schwarz (1998), apresentado anteriormente. A difusividade do soluto ao longo da discordância é maior quando o volume do átomo de soluto é maior que o do solvente. Como o raio atômico do nióbio é maior que o do alumínio, a difusão dos átomos de nióbio nas discordâncias de alumínio pode ter sido o mecanismo responsável pela reação observada por Lucadamo. Entretanto, o pré-requisito desse mecanismo é a existência de discordâncias na interface, e como, no caso dos filmes finos, essas discordâncias estão imóveis, a densidade de discordâncias tem que ser alta para que a reação forme uma camada homogênea. A não formação de compostos com outras composições junto à interface Al-Nb é discutida por Yoosoon e Morris Jr. (1988). Esses pesquisadores propõem que a preferência pela nucleação de $\mathrm{NbAl}_{3}$ junto à interface $\mathrm{Al}-\mathrm{Nb}$ e a dificuldade de formação dos demais intermetálicos do sistema Al-Nb, está ligada à barreira de energia associada à ordenação de curto alcance. A alegação principal é que a estrutura $\mathrm{D0}_{22}$ do $\mathrm{NbAl}_{3}$ seria formada mais facilmente, pela substituição de dois átomos de alumínio na estrutura CFC por dois átomos de nióbio.

As informações apresentadas permitem identificar a área específica de interface Al-Nb, bem como a densidade de discordâncias junto à interface, como variáveis determinantes no processo de síntese por reação exotérmica. A diminuição da periodicidade das camadas de alumínio e nióbio de $333 \mathrm{~nm}$ para $10 \mathrm{~nm}$ realizada por Lucadamo et al.(2001) corresponde a uma área de interface 33 vezes maior. Como a espessura da camada de $\mathrm{NbAl}_{3}$ formada na primeira etapa foi praticamente constante para todas as periodicidades, a fração volumétrica de transformação foi proporcional à área de interface. A transformação completa nessas condições ocorre por difusão no estado sólido, com uma duração inferior a um minuto. 
Alguns estudos sobre a dissolução de nióbio em alumínio líquido também fornecem informações úteis na análise do processo de síntese por combustão de $\mathrm{NbAl}_{3}$. Tunka e Smith (1989) e Tunka et al. (1990) observaram que a espessura da camada de $\mathrm{NbAl}_{3}$ formada após a imersão de um disco de nióbio em movimento rotativo em alumínio líquido, depende da concentração de nióbio no metal líquido. Uma vez atingida a concentração de saturação, a dissolução do intermetálico $\mathrm{NbAl}_{3}$ cessa e a espessura da camada aumenta continuamente. Tunka et al. (1989) e Lucadamo e Barmak (2001) constataram a formação de tensões na formação de $\mathrm{NbAl}_{3}$ devido a variação de volume molar durante a reação. Robin e Sandim (2002) ponderaram que, provavelmente, essas tensões na camada de $\mathrm{NbAl}_{3}$ são as responsáveis pelos sucessivos destacamentos da camada, restringindo o aumento da espessura, e mantendo um processo contínuo de dissolução do nióbio.

O processo de dissolução de nióbio em alumínio líquido corresponde a um processo macroscópico se comparado com as distâncias envolvidas em filmes finos. A área inicial de interface $\mathrm{Al}-\mathrm{Nb}$ corresponde à superfície do corpo-de-prova de nióbio. Robin e Sandim (2002) observaram que, para a temperatura de $750^{\circ} \mathrm{C}$, a variação de massa do corpo-de-prova começa a ser significativa somente após 48 horas de imersão.

As condições encontradas na preparação de misturas de $\mathrm{Al}-\mathrm{Nb}$ por metalurgia do pó são intermediárias as apresentadas nos parágrafos anteriores. A utilização de pós com distribuição granulométrica fina e o controle da densidade a verde, conferem ao compactado uma elevada área específica de interface $\mathrm{Al}-\mathrm{Nb}$, mas, devido à contaminação da superfície das partículas, que é inerente ao processo, a qualidade do contato entre partículas é inferior à observada em filmes finos.

No processo de ativação mecânica a contaminação da mistura pode ser inevitável. A moagem com alta energia de materiais dúcteis tem limitações técnicas que são intrínsecas ao processo. A alta capacidade de deformação de materiais dúcteis dificulta o fenômeno de cominuição, associado à fratura das partículas, e a grande geração de superfícies novas e livres de contaminações favorece o fenômeno de caldeamento das partículas. Essas duas características levam a um aumento do tamanho de partícula, o que pode inviabilizar o processo de moagem. A utilização de um agente controlador de processo (ACP) dificulta o processo de soldagem devido à contaminação das superfícies simultaneamente à 
sua geração. Esse procedimento permite $\mathrm{o}$ controle da distribuição granulométrica, sobretudo nos momentos iniciais da moagem. Com o decorrer do processo de moagem as partículas aumentam de resistência mecânica devido ao processo de encruamento, aumentando a probabilidade de fratura. A partir desse ponto, a conseqüência da presença do ACP é a diminuição do tamanho de partícula.

A presença do agente controlador de processo junto às interfaces, durante o processo de colisão das esferas de moagem, pode provocar quatro situações distintas. Na primeira, a quantidade de ACP é suficiente para evitar o processo de soldagem e a energia envolvida no choque, bem como a reatividade da nova superfície, não são suficientes para provocar sua decomposição. Essa é a situação que se busca otimizar quando o objetivo é reduzir o tamanho das partículas. Salientando que, como o processo de moagem consiste num balanço entre soldagem e fratura, a inibição do processo de soldagem favorece a diminuição do tamanho de partícula. Na segunda situação possível, a soldagem também é evitada, mas o ACP se decompõe total ou parcialmente. Neste caso, apesar da probabilidade de redução do tamanho de partícula existir, a quantidade total de ACP disponível para os próximos eventos diminui. A terceira e quarta situações referem-se à ocorrência de soldagem com e sem a decomposição do ACP. Note-se que a soldagem sem a decomposição do ACP compreenderia a oclusão do ACP. No caso de soldagem com decomposição, os produtos formados podem ficar retidos na interface ou se difundir nas estruturas cristalinas. 


\section{MATERIAIS E MÉTODOS}

\subsection{ESTRATÉGIA DE INVESTIGAÇÃO}

A parte experimental deste trabalho foi estruturada em três conjuntos principais de experimentos: misturas simples, misturas moídas com 1,9\% de ACP e misturas moídas com 1,0\% de ACP. A comparação entre mistura simples e mistura moída permitiu avaliar o efeito da ativação mecânica e a comparação entre as misturas moídas com quantidades de ACP diferentes permitiu avaliar o efeito do ACP na ativação mecânica. Nos três conjuntos, a resposta principal foi o perfil térmico da mistura registrado durante o aquecimento até a estabilização da temperatura, após a reação de combustão ter sido completada. Nas FIG. 8, 9 e 10 estão apresentadas as seqüências de preparação das misturas, bem como suas codificações.

\section{PRIMEIRO CONJUNTO: MISTURAS SIMPLES (S)}

Característica principal.

Todas as misturas desse conjunto foram homogeneizadas sem ativação mecânica simultânea. As interfaces entre partículas de nióbio e alumínio foram formadas no processo de compactação.

Objetivo.

Avaliação do efeito da densidade de defeitos cristalinos sobre as características da reação de combustão simultânea de misturas simples.

Estratégia.

A mistura de materiais como recebidos (CR), com baixa densidade de defeitos cristalinos, foi comparada com a mistura de materiais pré-ativados (PA), que continham alta densidade de defeitos cristalinos.

Misturas preparadas a partir da combinação das condições CR e PA, denominadas misturas híbridas, foram processadas com o intuito de se avaliar o efeito da alteração da densidade de defeitos cristalinos de apenas um dos reagentes. 


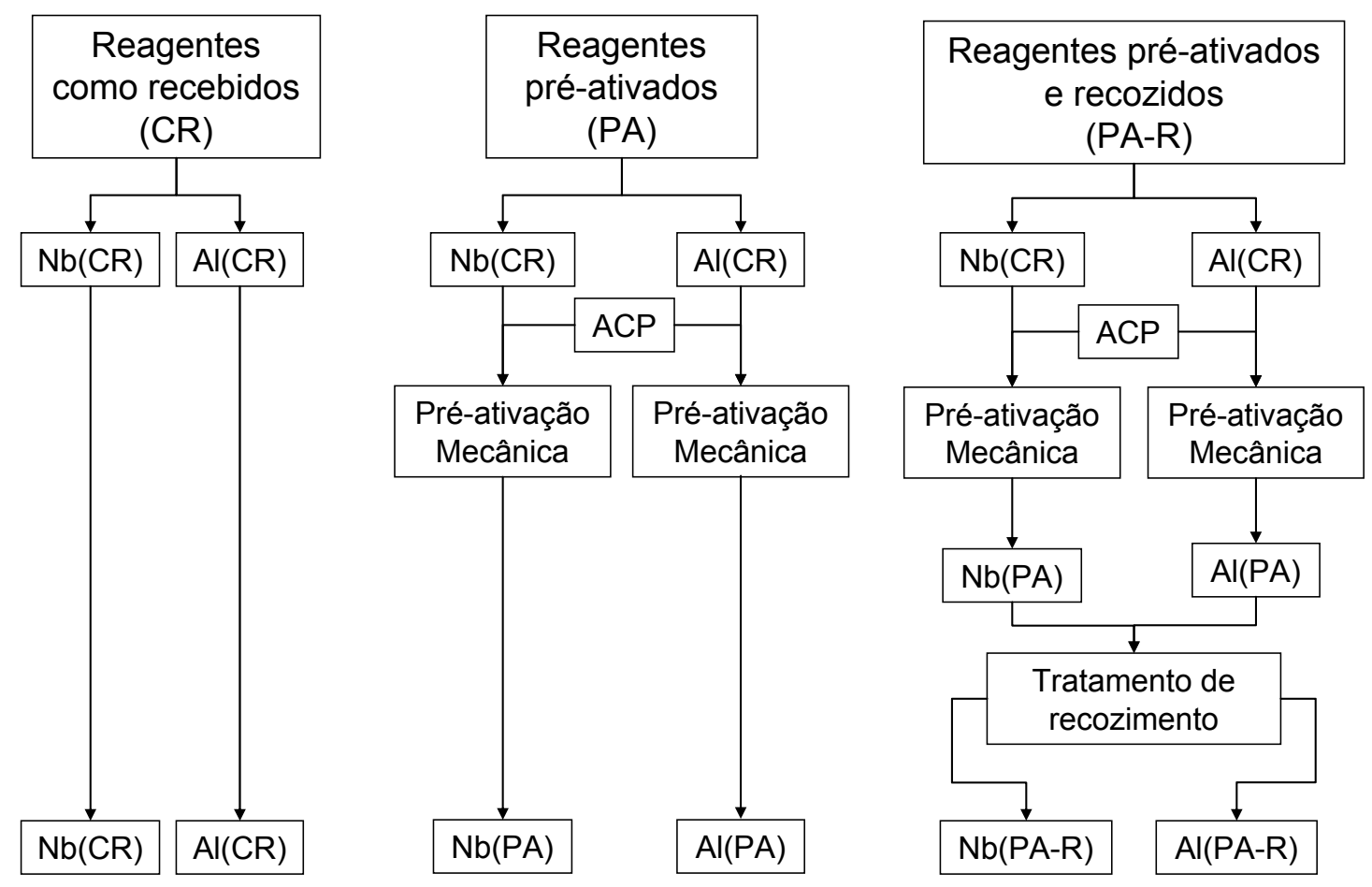

FIGURA 8 - Quadro comparativo da seqüência de preparação dos reagentes utilizados nas misturas simples e nas misturas moídas.

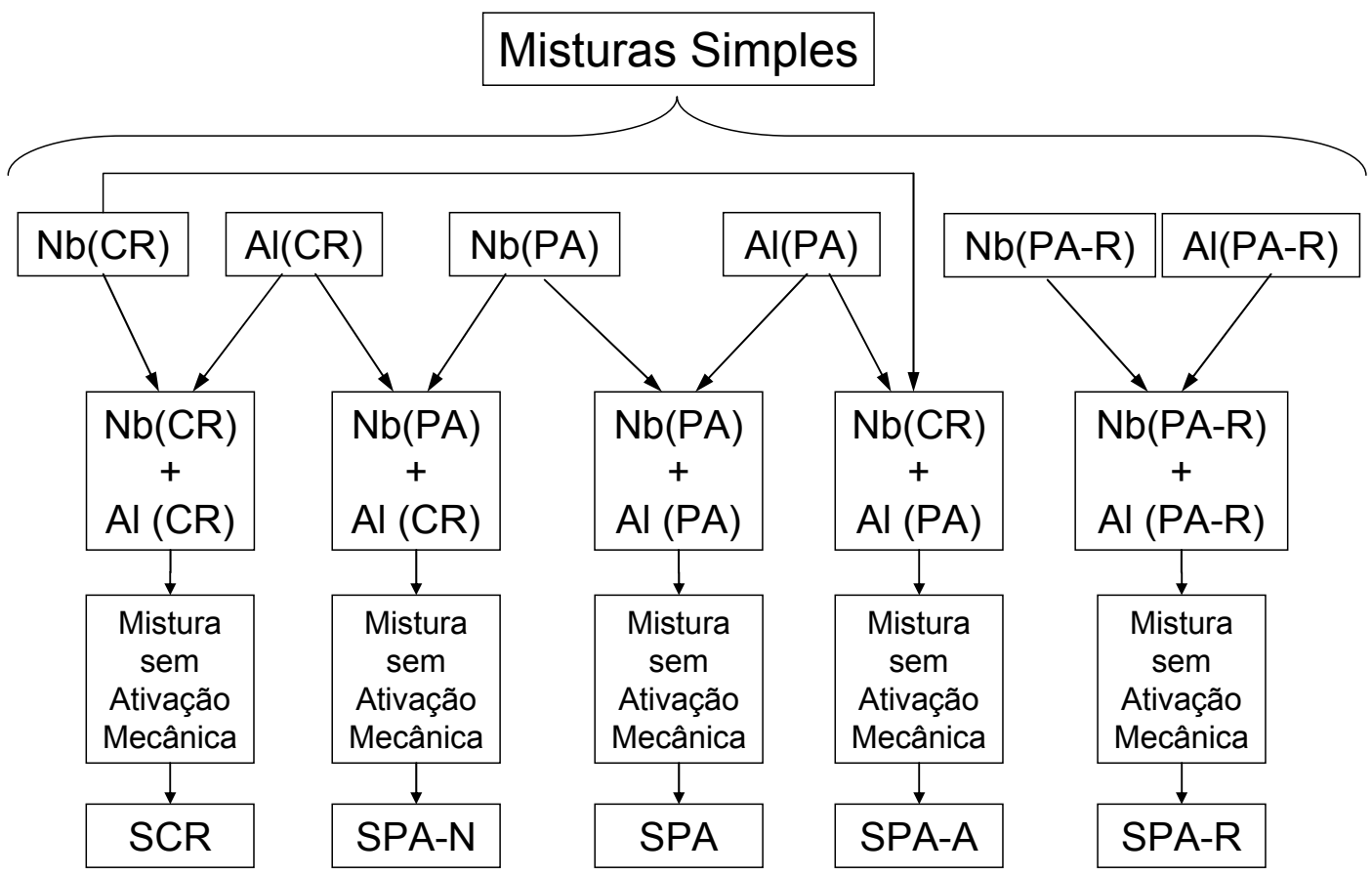

FIGURA 9 - Tipos de misturas simples avaliadas e suas codificações. 


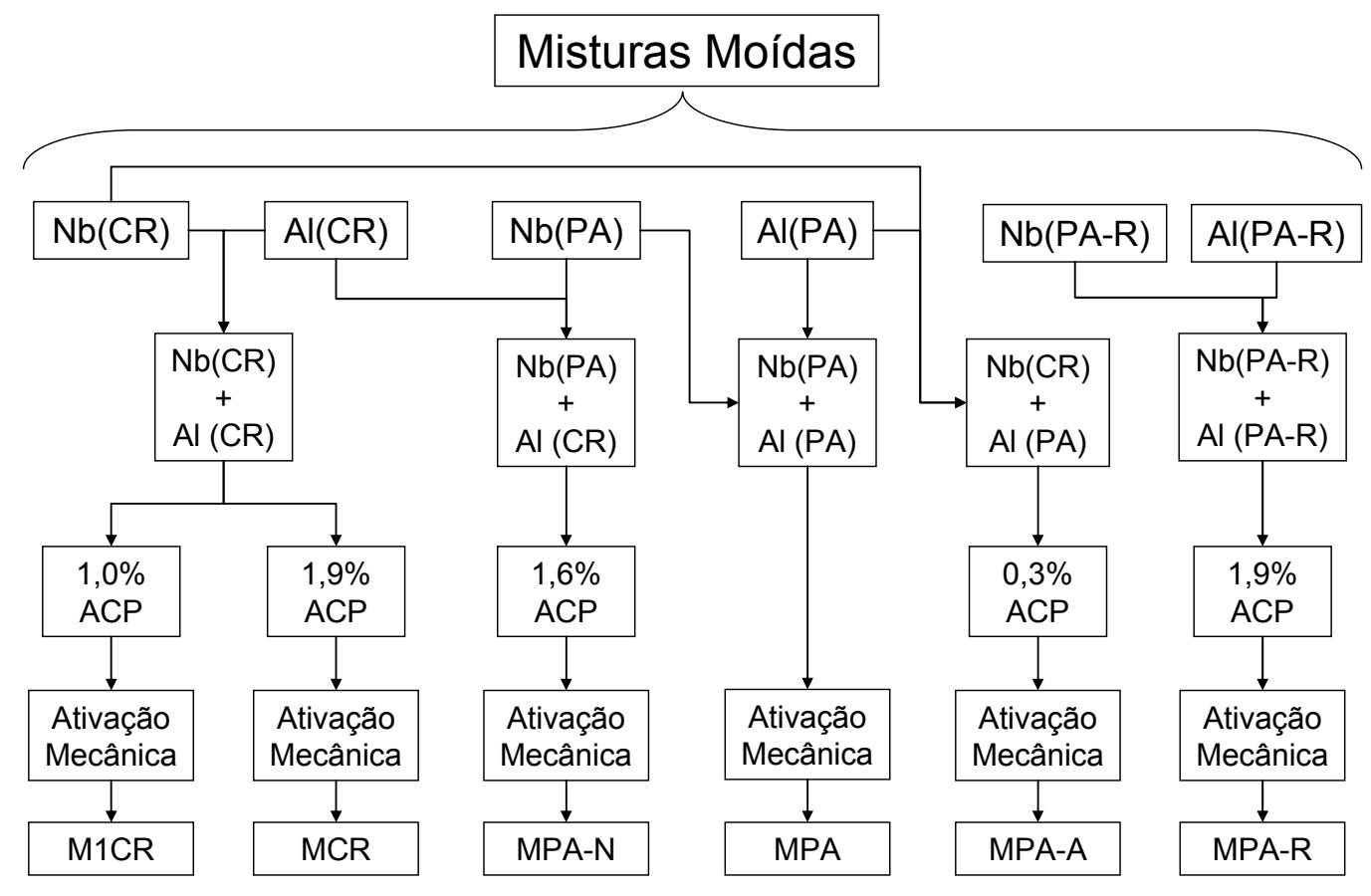

FIGURA 10 - Tipos de misturas moídas avaliadas e suas codificações.

Como a pré-ativação alterou a distribuição de tamanho de partícula dos reagentes, introduzindo uma segunda variável, foram realizados recozimentos nos materiais pré-ativados com o objetivo de se obter reagentes com baixa densidade de defeitos cristalinos e com distribuições granulométricas equivalentes aos reagentes pré-ativados. A mistura dos materiais recozidos (PA-R) foi então comparada com mistura de materiais pré-ativados (PA).

Limitação da estratégia.

O procedimento de pré-ativação utiliza necessariamente adições de ácido esteárico como agente controlador de processo (ACP), substância ausente nas misturas de materiais como recebidos, caracterizando uma segunda variável.

\section{SEGUNDO CONJUNTO: MISTURAS MOÍDAS COM 1,9\% DE ACP (M)}

Característica principal.

Todas as misturas desse conjunto continham 1,9\% em peso de ACP e foram homogeneizadas com ativação mecânica simultânea em moinhos com alta energia. As interfaces entre partículas de nióbio e alumínio foram formadas nos processos de moagem e de compactação. 
Objetivo.

Avaliação do efeito do tipo de dispersão, do aumento da área de interface entre os reagentes e dos diferentes níveis de densidades de defeitos cristalinos sobre as características da reação de combustão simultânea de misturas moídas.

Estratégia.

As misturas moídas de materiais como recebidos (CR), com baixa densidade de defeitos cristalinos, foram comparadas com misturas moídas de materiais pré-ativados (PA), que continham alta densidade de defeitos cristalinos. Dois tempos de moagem foram utilizados visando uma diferenciação microestrutural bem acentuada. Esse procedimento permitiu avaliar o efeito da pré-ativação sobre o processo de dispersão dos reagentes durante a moagem.

Misturas preparadas a partir da combinação das condições CR e PA (misturas híbridas) foram processadas com o intuito de se avaliar o efeito da alteração da densidade de defeitos cristalinos de apenas um dos reagentes.

Uma mistura moída de materiais recozidos (PA-R) foi comparada com uma mistura moída de materiais pré-ativados. Considerando que o tratamento de recozimento não altera significativamente a distribuição granulométrica dos reagentes, essa comparação permitiu avaliar o efeito da densidade de defeitos cristalinos e da capacidade de deformação plástica das partículas.

Limitação da estratégia.

O efeito do aumento da área de interface não pode ser totalmente isolado do efeito da densidade de defeitos cristalinos. Isso porque não é possível produzir uma mistura moída com densidade de defeitos cristalinos equivalente aos materiais recozidos. Não é possível, tão pouco, recozer uma mistura moída sem induzir reações entre os reagentes.

\section{TERCEIRO CONJUNTO: MISTURAS MOÍDAS COM 1,0\% DE ACP (M1)}

Característica principal.

Todas as misturas desse conjunto continham 1,0\% em peso de ACP e foram homogeneizadas com ativação mecânica simultânea em moinhos com alta energia. As interfaces formadas entre partículas de nióbio e alumínio foram formadas nos processos de moagem e de compactação. 
Objetivo.

Avaliação o efeito do teor de ACP sobre as características da reação de combustão simultânea de misturas moídas.

Estratégia.

Misturas moídas de materiais como recebidos (CR) com 1,0\% de ACP foram comparadas com misturas moídas de materiais como recebidos $(\mathrm{CR})$ com $1,9 \%$.

Limitação da estratégia.

Não houve.

\subsection{MATERIAIS}

Os materiais de partida, utilizados nos processos de moagem com alta energia e de síntese por combustão, são nióbio e alumínio na forma particulada. Tais materiais foram denominados pelo termo "como recebido" no decorrer deste trabalho, por se tratar da condição de fornecimento do material pelo fabricante.

O pó de nióbio foi fornecido com grau de pureza de 99\% e granulometria -325 mesh (Escola de Engenharia de Lorena, EEL). O pó foi produzido pelo processo hidretação-moagem-desidretação. O pó de alumínio foi produzido por atomização gasosa e foi fornecido com um grau de pureza de 99,7\% e granulometria -325 mesh (Alcoa).

Nas moagens com alta energia, utilizou-se um agente controlador de processo (ACP) com a finalidade de controlar o tamanho de partícula e minimizar a adesão das partículas metálicas na superfície do copo e das esferas. A substância utilizada foi ácido esteárico no estado particulado com 95\% de pureza (B.Herzog Varejo de Produtos Químicos Ltda.). A faixa de fusão especificada pelo fabricante é de $65^{\circ} \mathrm{C}$ a $68^{\circ} \mathrm{C}$. Sua fórmula química é $\mathrm{CH}_{3}\left(\mathrm{CH}_{2}\right)_{16} \mathrm{COOH}$, com uma densidade de $0,94 \mathrm{~g} / \mathrm{cm}^{3}$ a $20^{\circ} \mathrm{C}$. 


\subsection{MÉTODOS}

\subsubsection{PROCEDIMENTO DE PRÉ-ATIVAÇÃO E RECOZIMENTO}

O procedimento de pré-ativação do alumínio e do nióbio como recebidos, consistiu em submeter, separadamente, cada material a um processo de moagem com alta energia por um longo período de tempo, a fim de aumentar a densidade de defeitos cristalinos. As pré-ativações foram realizadas num moinho do tipo planetário, marca Fritsch, modelo Pulverisette ${ }^{\circledR}$ 5. As condições de moagem estão apresentadas na TAB.2. A quantidade de ACP definida na TAB.2 foi determinada experimentalmente. $O$ critério utilizado baseou-se no rendimento de fração fina de partículas (-325\#) obtida após o processo de moagem. As proporções de ACP adotadas proporcionaram rendimentos acima de $80 \%$, para o alumínio, e acima de $90 \%$, para o nióbio.

Os recozimentos dos materiais pré-ativados foram realizados a vácuo $\left(<10^{-4}\right.$ bar) por um período de 8 horas. A temperatura de patamar foi de $1000{ }^{\circ} \mathrm{C}$ para o nióbio e $550^{\circ} \mathrm{C}$ para o alumínio. Os pós recozidos foram desaglomerados em almofariz e peneirados em peneiras -325 mesh.

TABELA 2 - Condições de moagem adotadas no procedimento de pré-ativação.

\begin{tabular}{|c|c|c|}
\hline Tipo de moinho & \multicolumn{2}{|c|}{ Planetário } \\
\hline Material do copo de moagem & Aço inoxidável ABNT 420 endurecido \\
\hline Material das esferas de moagem & \multicolumn{2}{|c|}{ Aço ABNT 52100 endurecido } \\
\hline Volume do copo $\left(\mathrm{cm}^{3}\right)$ & \multicolumn{2}{|c|}{270} \\
\hline Material & Alumínio & Nióbio \\
\hline $\begin{array}{c}\text { Razão pó-ACP em volume } \\
\text { (\% em peso) }\end{array}$ & $\begin{array}{c}10: 1 \\
(3,48 \%)\end{array}$ & $\begin{array}{c}20: 1 \\
(0,55 \%)\end{array}$ \\
\hline $\begin{array}{c}\text { Razão esfera-pó em volume } \\
\text { (em peso) }\end{array}$ & \multicolumn{2}{|c|}{$5: 1$} \\
$(9,2: 1)$ \\
\hline Diâmetro das esferas (mm)
\end{tabular}




\subsubsection{DESCRIÇÃO DAS MISTURAS}

Todas as reações de combustão simultânea foram realizadas em misturas de nióbio e alumínio na proporção atômica de $75 \%$ de alumínio $\left(\mathrm{Nb}_{25} \mathrm{Al}_{75}\right)$. A proporção em peso dessas misturas é de $46,6 \%$ de alumínio. Os materiais utilizados na elaboração das misturas podem ser como recebidos (CR) ou préativados (PA). As misturas simples (S) foram preparadas em moinho tipo agitador, marca SPEX® modelo 8000 , utilizando um copo de aço 52100 sem a utilização de esferas. $O$ tempo de homogeneização foi de 60 minutos para todas as misturas.

As misturas moídas ( $\mathrm{M}$ e $\mathrm{M} 1$ ) foram preparadas no mesmo moinho utilizado na homogeneização. As condições de moagem são discutidas no item seguinte. No caso de misturas hibridas foram utilizadas as terminações PA-A ou PA-N para indicar qual dos dois elementos foi utilizado na condição pré-ativada. As misturas que utilizaram os materiais submetidos ao tratamento de recozimento são identificadas pela terminação PA-R. O prefixo $M 1$ será utilizado na identificação das misturas moídas com 1,0\% de ACP. Na TAB.3 está apresentada a codificação das misturas avaliadas neste trabalho.

TABELA 3 - Codificação das misturas de pós de alumínio e nióbio utilizadas.

\begin{tabular}{|c|c|c|c|c|c|c|c|c|c|}
\hline \multicolumn{5}{|c|}{ Misturas Simples } & \multicolumn{5}{|c|}{ Misturas Moídas } \\
\hline \multirow{3}{*}{$\begin{array}{c}\text { Código da } \\
\text { Mistura }\end{array}$} & \multicolumn{4}{|c|}{ Estado do pó } & \multirow{3}{*}{$\begin{array}{c}\text { Código da } \\
\text { Mistura }\end{array}$} & \multicolumn{4}{|c|}{ Estado do pó } \\
\hline & \multicolumn{2}{|c|}{$\begin{array}{c}\text { Como } \\
\text { Recebido }\end{array}$} & \multicolumn{2}{|c|}{$\begin{array}{c}\text { Pré- } \\
\text { Ativado }\end{array}$} & & \multicolumn{2}{|c|}{$\begin{array}{c}\text { Como } \\
\text { Recebido }\end{array}$} & \multicolumn{2}{|c|}{$\begin{array}{l}\text { Pré- } \\
\text { Ativado }\end{array}$} \\
\hline & $\mathrm{Al}$ & $\mathrm{Nb}$ & $\mathrm{Al}$ & $\mathrm{Nb}$ & & Al & $\mathrm{Nb}$ & $\mathrm{Al}$ & $\mathrm{Nb}$ \\
\hline SCR & $\mathrm{X}$ & $X$ & & & $M C R$ e M1CR & $\mathrm{X}$ & $\mathrm{X}$ & & \\
\hline SPA & & & $\mathrm{X}$ & $\mathrm{X}$ & MPA & & & $\mathrm{X}$ & $\mathrm{X}$ \\
\hline SPA-N & $\mathrm{x}$ & & & $x$ & MPA-N & $X$ & & & $x$ \\
\hline SPA-A & & $x$ & $X$ & & MPA-A & & $\mathrm{x}$ & $x$ & \\
\hline SPA-R & & & $\star$ & $\star$ & MPA-R & & & $\star$ & $\star$ \\
\hline
\end{tabular}

$\star$ Materiais pré-ativados e recozidos 


\subsubsection{DESCRIÇÃO DAS MOAGENS}

As condições de moagem para todas as misturas estão apresentadas na TAB.4. O tempo de moagem e o tipo de mistura foram os únicos parâmetros variados no processo de moagem. A etapa de retirada do pó após a moagem foi realizada com a abertura do copo em caixa de luvas sob atmosfera de argônio comercial, respeitando um tempo mínimo dentro da caixa de 2 horas, seguido de passivação natural ao ar por no mínimo 12 horas antes da retirada do pó de dentro do copo. Todas as moagens de misturas foram realizadas num moinho tipo agitador, marca SPEX® modelo 8000.

O teor de 1,9\% em peso fixado para o segundo conjunto de experimentos teve como referência as porcentagens utilizadas nas pré-ativações do nióbio e do alumínio. Nas misturas $\mathrm{Nb}_{25} \mathrm{Al}_{75}$, a partir de reagentes pré-ativados, a combinação das quantidades de ACP, já adicionadas no processo de pré-ativação, determina uma proporção em volume entre pó e ACP de 11,5:1 (1,9\% em peso de ACP). No caso do terceiro conjunto de experimentos, o teor de $1,0 \%$ foi definido por ser 0 valor mínimo necessário para manter o tamanho médio de partícula abaixo de $100 \mu \mathrm{m}$ (Rocha et al., 2003).

TABELA 4 - Condições adotadas nas moagens de misturas.

\begin{tabular}{|c|c|c|}
\hline Tipo de moinho & \multicolumn{2}{|c|}{ Agitador } \\
\hline Material do copo de moagem & \multicolumn{2}{|c|}{ Aço inoxidável ABNT 420 endurecido } \\
\hline Material das esferas de moagem & \multicolumn{2}{|c|}{ Aço ABNT 52100 endurecido } \\
\hline Volume do copo $\left(\mathrm{cm}^{3}\right)$ & \multicolumn{2}{|c|}{93} \\
\hline $\begin{array}{c}\text { Razão pó-ACP em volume } \\
\text { (\% em peso) }\end{array}$ & $\begin{array}{l}11,5: 1 \\
(1,9 \%)\end{array}$ & $\begin{array}{l}22: 1 \\
(1,0 \%)\end{array}$ \\
\hline Razão esfera-pó em volume & \multicolumn{2}{|c|}{$5: 1$} \\
\hline Diâmetro das esferas (mm) & \multicolumn{2}{|c|}{$5,55-3,17$} \\
\hline Quantidade de esferas & \multicolumn{2}{|c|}{$125-675$} \\
\hline Atmosfera de moagem & \multicolumn{2}{|c|}{ Argônio comercial } \\
\hline Tempos de moagem (minutos) & \multicolumn{2}{|c|}{20 e 120} \\
\hline
\end{tabular}




\subsubsection{CARACTERIZAÇÃO DOS MATERIAIS APÓS MOAGEM}

Os produtos das moagens com alta energia, tanto no caso do moinho planetário quanto no moinho agitador, foram caracterizados em microscópio eletrônico de varredura, marca Philips, modelo X30. Os modos de observação adotados foram denominados "pó solto" e "pó embutido". O primeiro procedimento consiste em dispersar uma amostra do pó de interesse sobre um substrato adesivo posicionado sobre um porta-amostra. Essa dispersão é submetida ao processo de deposição de um filme fino de ouro ("sputtering" ou "PVD") com o objetivo de criar uma camada eletricamente condutora. No segundo modo, uma amostra do pó é misturada a uma quantidade de resina do tipo epóxi. Após a cura da resina, a amostra é lixada e polida, seguindo o procedimento padrão de preparação de amostras metalográficas. Antes da observação no microscópio eletrônico, essas amostras também necessitam de um filme fino eletricamente condutor, mas neste caso, a técnica utilizada foi a de evaporação de carbono.

Cada moagem também foi avaliada quanto à distribuição de tamanho de partícula utilizando a técnica de difração de laser em equipamento Cilas $®$, modelo 1064. Todas as amostras foram dispersas em uma solução aquosa com pirofosfato de sódio com auxílio de ultra-som.

Algumas condições de moagem foram selecionadas para a realização de ensaios de difração de raios $x$. Os difratogramas foram realizados na faixa angular (20) entre $5^{\circ}$ e $130^{\circ}$, com passo de $0,02^{\circ}$ e tempo por passo de $5 \mathrm{~s}$. Todos os difratogramas foram analisados pelo método de Rietveld (Rietveld, 1969, 1967), quanto à posição e à intensidade dos picos, à fração volumétrica das fases presentes e ao alargamento dos picos, devido à microdeformação elástica e ao tamanho de cristalito. O programa MAUD® foi utilizado na realização dessas análises. (Lutterotti e Scardi, 1990; Lutterotti e Gialanella, 1998; Scardi et al., 1994, Popa, 1998). As principais equações utilizadas pelo programa Maud®, na determinação da intensidade calculada, estão apresentadas no anexo.

O método de Rietveld consiste basicamente no ajuste de uma função teórica, que descreve a variação da intensidade de difração em função do ângulo de difração, às intensidades observadas experimentalmente. Esse ajuste é realizado pelo método dos mínimos quadrados não linear, onde os parâmetros 
das funções são definidos inicialmente e recalculados (refinados) interativamente ao longo do processo de ajuste.

A qualidade do ajuste, durante o refinamento dos difratogramas, foi monitorada pela soma quadrática ponderada das diferenças (WSS) e pelos índices $R_{w p}$ e $R_{\exp }$, calculados segundo as seguintes equações:

$$
\begin{aligned}
& \text { WSS }=\sum_{i=1}^{N}\left[w_{i}\left(I_{i}^{\exp }-I_{i}^{\text {calc }}\right)\right]^{2} \quad \text { onde }: w_{i}=\frac{1}{\sqrt{I_{i}^{\exp }}} \\
& R_{w p}=\sqrt{\frac{\sum_{i=1}^{N}\left[w_{i}\left(I_{i}^{\exp }-I_{i}^{\text {calc }}\right)\right]^{2}}{\sum_{i=1}^{N}\left(w_{i} I_{i}^{\exp }\right)^{2}}} \quad R_{\exp }=\sqrt{\frac{(N-P)}{\sum_{i=1}^{N}\left(w_{i} I_{i}^{\exp }\right)^{2}}} \\
& \text { Qualidade de ajuste }=\frac{R_{w p}}{R_{\exp }}
\end{aligned}
$$

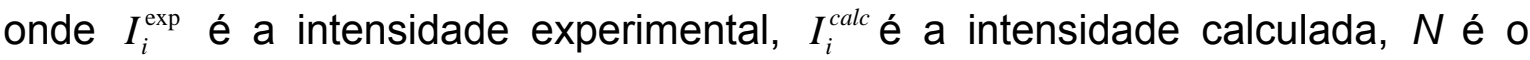
número de pontos do difratograma e $P$ é o número de parâmetros refinados.

O alargamento dos picos de Bragg referente à dispersão de comprimento de onda do feixe de raios $x$ e as aberrações óticas do difratômetro (alargamento instrumental) foi avaliada utilizando uma amostra particulada de ítria $\left(\mathrm{Y}_{2} \mathrm{O}_{3}\right)$, com pureza de 99,999\%, recozida por 72 horas a $1200^{\circ} \mathrm{C}$. A avaliação por microscopia de transmissão da amostra tratada mostrou uma microestrutura com baixo nível de deformação e tamanho de cristalito variando entre $200 \mathrm{~nm}$ e $400 \mathrm{~nm}$, portanto, acima de $100 \mathrm{~nm}$, considerado o limite superior da influência do tamanho de cristalito no alargamento dos picos de Bragg.

\subsubsection{DESCRIÇÃO DAS COMPACTAÇÕES}

As pastilhas destinadas às reações de síntese foram compactadas em uma máquina universal de ensaios marca Instron, modelo 4400. A matriz utilizada foi do tipo flutuante com $14 \mathrm{~mm}$ de diâmetro. A compactação foi monitorada com base na altura da pastilha, com o objetivo de atingir uma densidade a verde de 
$75 \% \pm 1 \%$ da densidade teórica da mistura de $4,26 \mathrm{~g} / \mathrm{cm}^{3}$. Todas as compactações foram realizadas ao ar, com lubrificação da matriz com pó de estearato de zinco e uma velocidade de deslocamento do punção superior de $3 \mathrm{~mm} / \mathrm{min}$. A massa nominal de cada pastilha foi de 4,0 g. Para cada condição experimental foram compactadas três pastilhas para fins de reprodutibilidade.

A densidade a verde foi verificada pela massa e volume da pastilha. $O$ volume foi determinado por medidas geométricas, utilizando as médias de quatro medições da altura e quatro medições de diâmetro.

\subsubsection{DESCRIÇÃO DOS CICLOS TÉRMICOS}

As reações foram conduzidas em um forno resistivo tubular, dotado de controle programável de aquecimento. Cada pastilha foi inserida em um tubo de quartzo, selado em uma das extremidades e conectado a um sistema de vácuo na outra extremidade. O ciclo térmico foi composto de duas etapas principais. A primeira etapa visou promover uma desgaseificação da pastilha, minimizando a evolução de gases durante a reação exotérmica. Essa etapa foi realizada utilizando uma taxa de aquecimento de $2^{\circ} \mathrm{C} / \mathrm{min}$ entre $200^{\circ} \mathrm{C}$ e $450^{\circ} \mathrm{C}$. A segunda etapa consistiu no aquecimento, a partir de $450^{\circ} \mathrm{C}$ até a estabilização da temperatura após a reação, a uma taxa nominal de $30^{\circ} \mathrm{C} / \mathrm{min}$. O aquecimento entre a temperatura ambiente e $200^{\circ} \mathrm{C}$ foi realizado a $15^{\circ} \mathrm{C} / \mathrm{min}$ com o objetivo de minimizar o tempo de tratamento em baixas temperaturas.

A monitoração do ciclo térmico foi feita utilizando um sistema de aquisição de dados no qual a pressão do sistema e as temperaturas do forno e da pastilha foram registradas em função do tempo. A freqüência de aquisição de dados foi de 1 medida a cada 5 segundos na primeira etapa de aquecimento e de 10 medidas por segundo na segunda etapa de aquecimento. A temperatura da pastilha foi monitorada por um termopar tipo $S$ recoberto com lama de alumina, introduzido num furo de $2 \mathrm{~mm}$ de diâmetro por $4,5 \mathrm{~mm}$ de profundidade, localizado no centro de uma das faces planas da pastilha.

Optou-se por utilizar um termopar tipo $S$ devido a sua faixa de operação ser compatível com as altas temperaturas de combustão. Entretanto, em razão da 
alta reatividade da platina com o alumínio líquido, foi necessário utilizar um revestimento de lama de alumina na ponta do termopar, diminuindo a condutibilidade térmica local. A aplicação dessa lama foi artesanal e na menor quantidade possível, não sendo possível garantir o controle de espessura. $O$ posicionamento do termopar junto à pastilha também é fonte de variabilidade no procedimento. A execução do furo até aproximadamente metade da altura da pastilha teve como objetivo medir a temperatura da pastilha o mais próximo do seu centro. Para um monitoramento mais preciso da temperatura instantânea do centro da pastilha, procurou-se manter a ponta do termopar em contado constante com o fundo do furo maximizando a transferência de calor da pastilha ao termopar. Entretanto, a pastilha durante o aquecimento sofre pequenas movimentações como expansões e contrações que podem provocar a perda do contato do termopar com o fundo do furo. Essa situação é mais crítica durante a reação exotérmica quando os transientes térmicos são mais curtos. Finalizando, a temperatura de combustão foi o resultado com maior variabilidade. Apesar do teste de reprodutibilidade de três pastilhas adotado neste trabalho, com suas respectivas médias e desvios, a análise foi realizada considerando a pastilha com maior temperatura de combustão, baseando-se no princípio de que quanto maior tal temperatura melhor o contato do termopar com a pastilha.

O ciclo de aquecimento de algumas pastilhas foi abortado momentos antes da ignição, com o objetivo de avaliar as alterações microestruturais ocorridas antes da reação. O procedimento de interrupção consistiu na retirada do tubo de quartzo do forno seguido de resfriamento do tubo com ar forçado. O vácuo foi mantido durante todo o resfriamento. Dois critérios de definição do momento da interrupção foram utilizados. O primeiro utilizou a temperatura de ignição como referência. Esse critério foi aplicado nas pastilhas com temperatura de ignição acima de $800^{\circ} \mathrm{C}$. Neste caso a temperatura de interrupção foi de $820^{\circ} \mathrm{C}$. O segundo critério baseou-se no tempo de fusão do alumínio, sendo aplicado nas pastilhas com temperatura de ignição próximas à temperatura de fusão do alumínio. Neste caso as interrupções ocorreram $90 \mathrm{~s}$ e $150 \mathrm{~s}$ após o início da fusão do alumínio, dependendo do comportamento térmico da pastilha em questão. 


\subsubsection{CARACTERIZAÇÃO DOS CICLOS TÉRMICOS}

Os perfis de temperatura relativos à segunda etapa de aquecimento de cada pastilha foram analisados em diversos pontos para a determinação das seguintes características: tempo de fusão do alumínio $\left(t_{F A}\right)$, temperatura de ignição $\left(T_{1 \mathrm{G}}\right)$, temperatura de explosão térmica $\left(T_{\mathrm{ex}}\right)$, taxa de aquecimento máxima na reação ( $\mathrm{dT}_{\mathrm{MAX}}$ ), temperatura de combustão $\left(\mathrm{T}_{\mathrm{C}}\right)$, amplitude de aquecimento $(\Delta \mathrm{T})$, tempo de reação $\left(t_{R}\right)$ e taxa de aquecimento média na reação ( $\mathrm{dT}_{\mathrm{MED}}$ ).

O início da fusão do alumínio foi determinado pela intersecção entre reta representativa do aquecimento antes da fusão e a representativa do aquecimento durante o processo de fusão. O procedimento para a determinação do final da fusão teve como critério básico a aceleração da taxa de aquecimento.

A temperatura de ignição $\left(T_{I G}\right)$ foi determinada pela intersecção entre a reta de regressão relativa à taxa de aquecimento máxima ( $\left.\mathrm{dT}_{\mathrm{MAX}}\right)$ durante a reação e a reta de regressão do aquecimento linear imediatamente antes da reação. Nas misturas em que o aquecimento após o término da fusão do alumínio se acelera continuamente até atingir seu valor máximo durante a reação, a temperatura de ignição foi considerada igual a temperatura final do processo de fusão.

A temperatura de explosão térmica está relacionada com a taxa de aquecimento máxima. Quando a pastilha ultrapassa a temperatura de ignição a taxa de aquecimento aumenta continuamente até atingir a faixa de $70^{\circ} \mathrm{C} / \mathrm{s}$ a $100^{\circ} \mathrm{C} / \mathrm{s}$, quando ocorre uma aceleração súbita da temperatura até atingir a taxa de aquecimento máxima. Neste trabalho, a temperatura de explosão térmica foi definida como a temperatura onde a taxa de aquecimento ultrapassa $70^{\circ} \mathrm{C} / \mathrm{s}$.

$O$ tempo de reação $\left(t_{R}\right)$ foi definido como a diferença entre os valores de tempo na temperatura de ignição $\left(T_{1 G}\right)$ e na temperatura de combustão $\left(T_{C}\right)$, sendo que, esta última, pode ser obtida diretamente no perfil de temperatura.

A taxa de aquecimento média foi definida como a divisão da amplitude de aquecimento $(\Delta T)$, determinada pela diferença entre a temperatura de ignição $\left(T_{1 G}\right)$ e temperatura de combustão $\left(T_{C}\right)$, pelo tempo de reação $\left(t_{R}\right)$.

Na FIG.11 é apresentado um exemplo de perfil da temperatura da pastilha em função do tempo. Na FIG. 12 são apresentados três detalhamentos do perfil da FIG.11 com aplicação da metodologia de análise definida acima e um gráfico de taxa de aquecimento usado para determinar a temperatura de explosão térmica. 


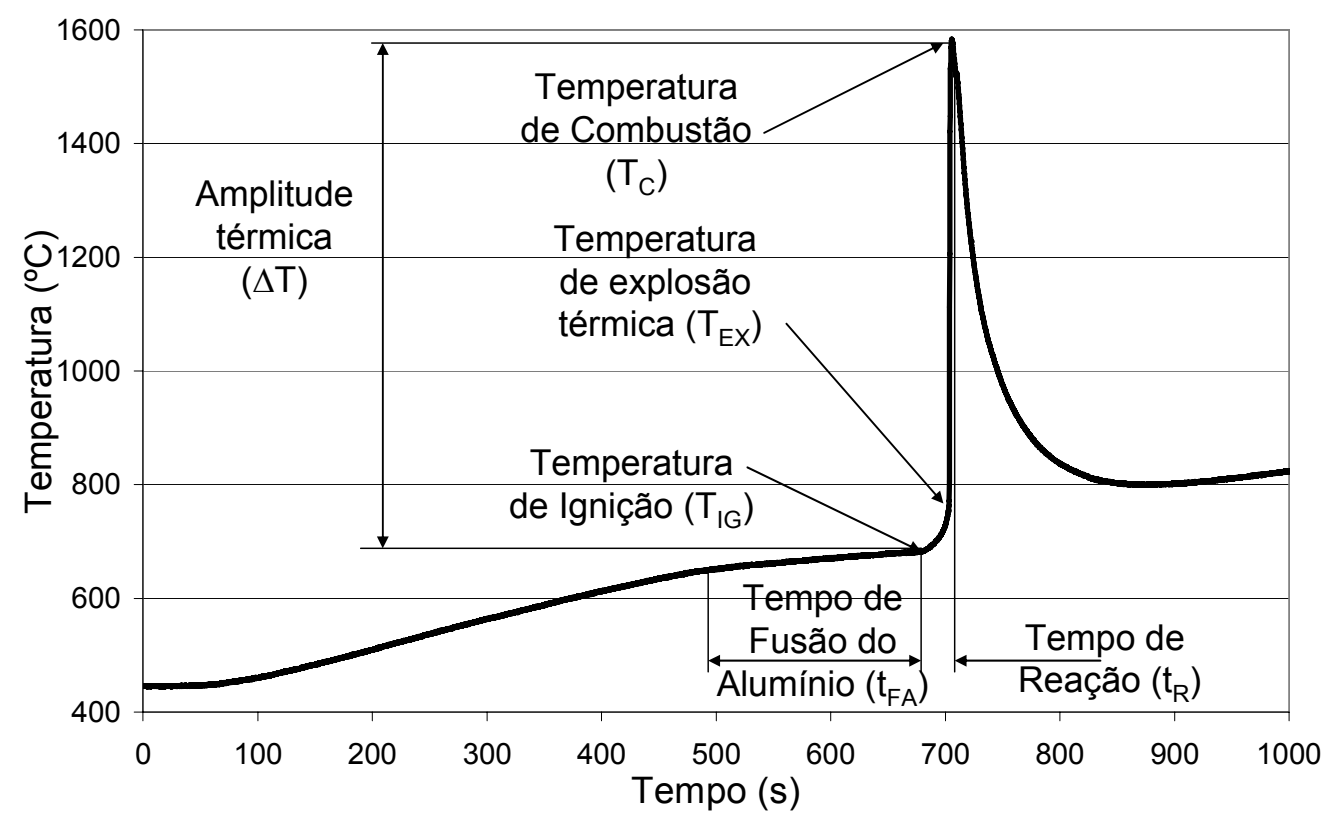

FIGURA 11 - Exemplo de perfil de temperatura da pastilha registrado pelo sistema de aquisição de dados.
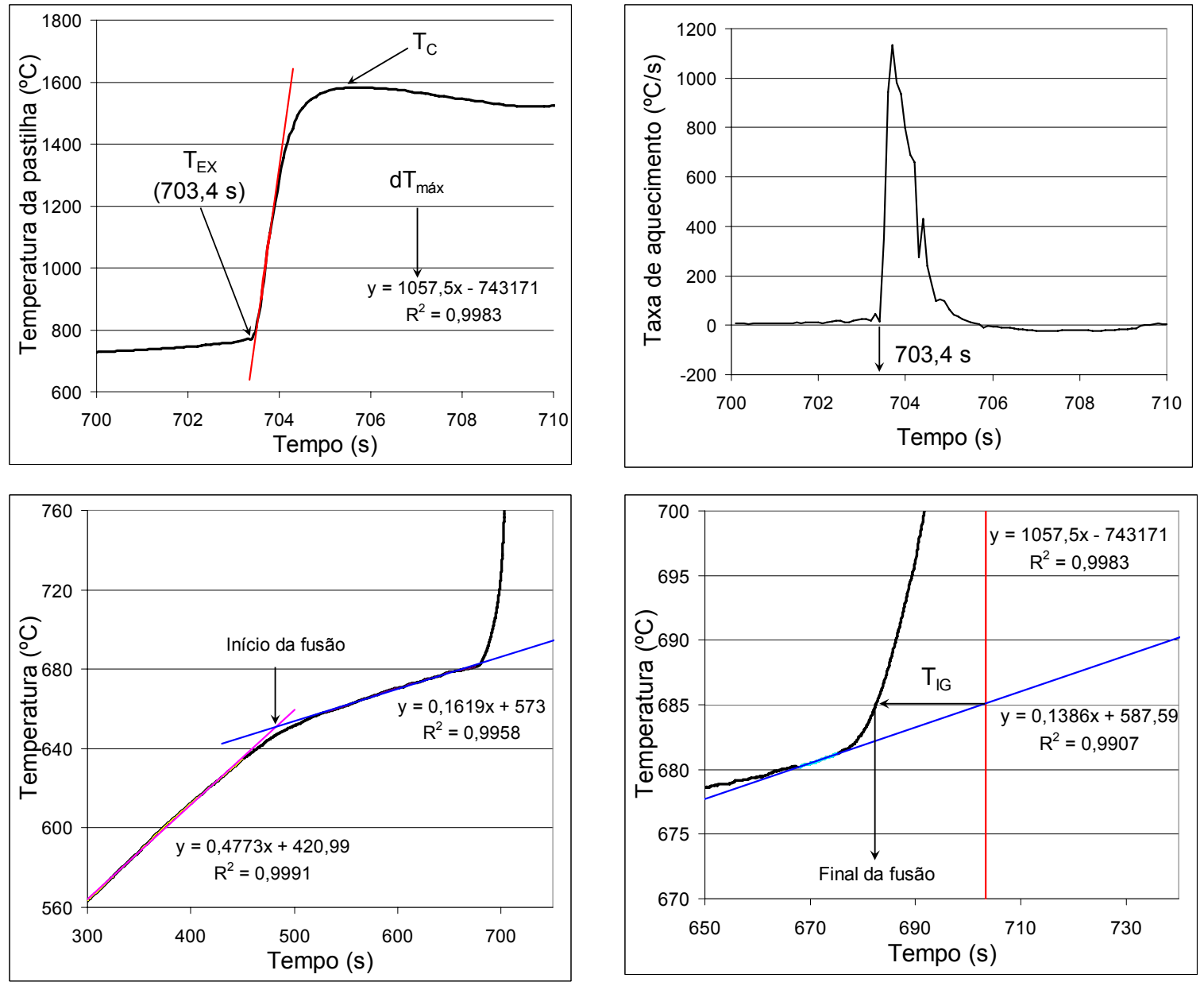

FIGURA 12 - Exemplo da metodologia de análise dos perfis de temperatura. 


\section{RESULTADOS}

\subsection{MISTURAS SIMPLES}

Os resultados obtidos neste primeiro conjunto de experimentos e expostos nos próximos itens permitiram as seguintes constatações:

a. O procedimento de pré-ativação aplicado aos pós como recebidos produziu estruturas nanocristalinas, com tamanhos de cristalito de 6,6 nm para o nióbio e de 36 nm para o alumínio;

b. O tratamento de recozimento dos reagentes pré-ativados promoveu o crescimento de tamanho de cristalito e a diminuição da microdeformação. Entretanto, esse efeito foi bem menor para o alumínio;

c. A decomposição do ácido esteárico (ACP) durante a moagem provocou a formação de solução sólida intersticial no nióbio de hidrogênio e possivelmente de oxigênio e carbono. $O$ tratamento de recozimento promoveu a precipitação de carbonetos e óxidos e a dessorção do hidrogênio;

d. No caso do alumínio, não houve formação de solução sólida, mas o tratamento de recozimento promoveu a precipitação de $\mathrm{Al}_{4} \mathrm{C}_{3}$;

e. As misturas que utilizaram nióbio pré-ativado apresentaram uma taxa de aquecimento quatro vezes maior que a verificada com material como recebido;

f. O comportamento térmico da mistura de reagentes recozidos permitiu concluir que o efeito preponderante de ativação mecânica foi proporcionado pela redução do tamanho médio de partícula do nióbio;

g. A utilização de reagentes pré-ativados produziu, durante a reação de combustão, uma grande quantidade de óxidos e carbonetos, distribuídos de forma heterogênea numa matriz de $\mathrm{NbAl}_{3}$;

h. A pré-ativação do alumínio teve um efeito deletério sobre o processo de síntese por combustão em razão de formação de $\mathrm{Al}_{4} \mathrm{C}_{3}$ antes da reação. Esse efeito pode ser minimizado com a utilização de nióbio com tamanho médio de partícula menor. 


\subsubsection{MICROSCOPIA E DISTRIBUIÇÃO GRANULOMÉTRICA}

A forma e distribuição do tamanho de partícula do alumínio como recebido e pré-ativado são apresentadas na FIG.13. O aspecto arredondado do pó de alumínio como recebido (FIG.13A) é conseqüência do processo de atomização a gás, utilizado na produção do pó. Após a moagem de pré-ativação as partículas adquiriram um aspecto facetado, indicando a presença de deformação e fratura na formação das partículas (FIG.13B). A pré-ativação reduziu o tamanho médio de partícula de $41 \mu \mathrm{m}$ para $26 \mu \mathrm{m}$ e reduziu a amplitude de dispersão de tamanhos como pode ser observado pela diferença entre os diâmetros relativos a $10 \%$ e $90 \%$.

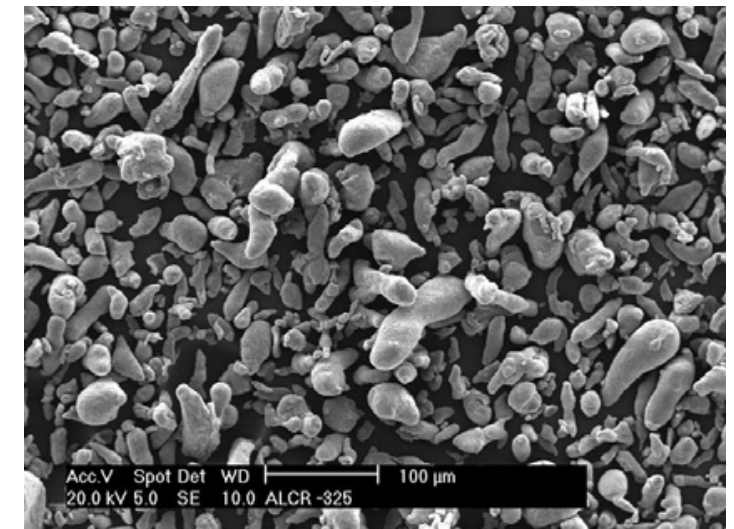

A - como recebido

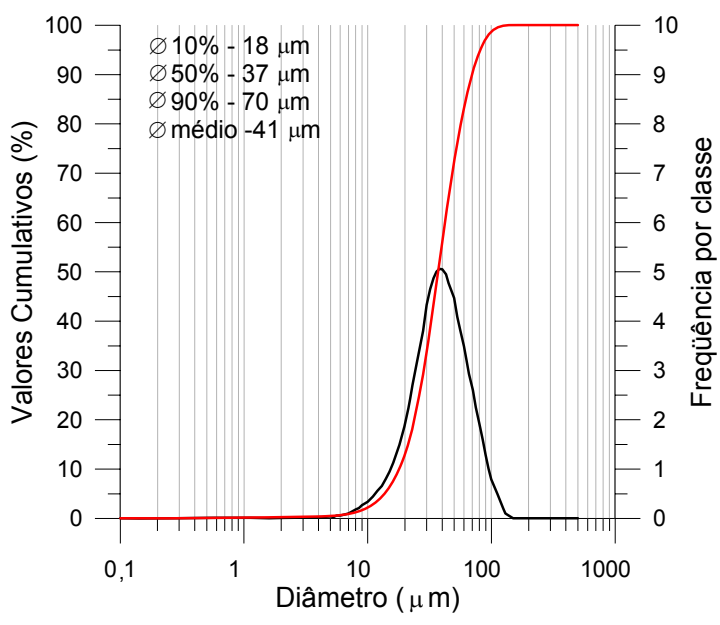

C - como recebido

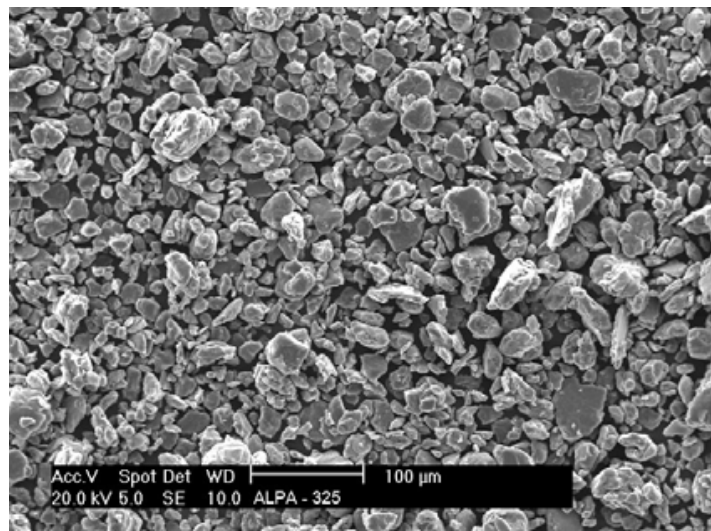

$\mathrm{B}$ - pré-ativado

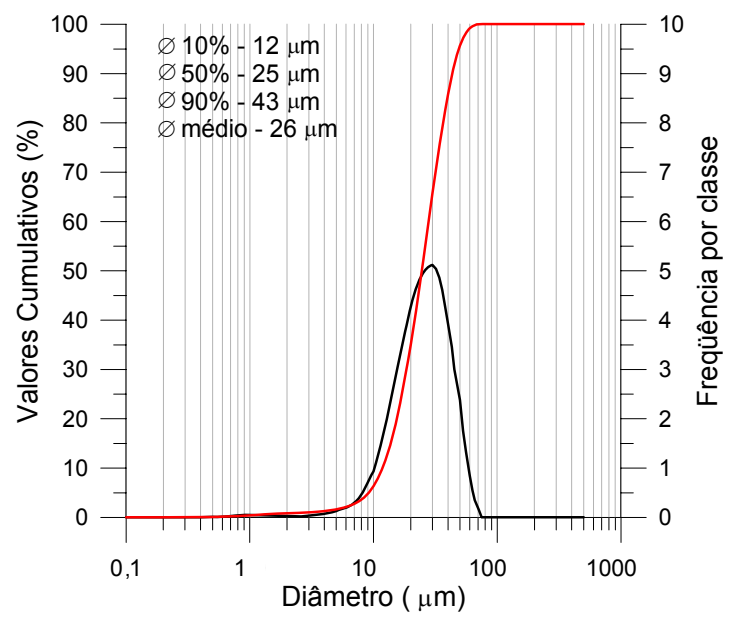

D - pré-ativado

FIGURA 13 - Micrografias e distribuições de tamanho de partículas do alumínio nas condições como recebida e pré-ativada. 
A forma e a distribuição do tamanho de partícula do nióbio como recebido e pré-ativado são apresentadas na FIG.14. O processo de hidretação-moagemdesidretação empregado para a obtenção de pó de nióbio, tem como princípio fragilizar o nióbio pela formação de hidretos para, em seguida, submetê-lo ao processo de moagem. Essa fragilização aumenta a probabilidade de fratura pelo mecanismo de clivagem, conferindo ao pó o aspecto facetado observado na FIG.14A. A moagem com alta energia reduziu significativamente o tamanho médio de partícula, produzindo uma distribuição trimodal, com modas de $0,25 \mu \mathrm{m}$, 2,6 $4 \mathrm{~m}$ e $11 \mu \mathrm{m}$ (FIG.14D). No caso do pó de nióbio como recebido, a distribuição do tamanho de partícula é assimétrica, com a moda em torno de $35 \mu \mathrm{m}$ e uma média de $24 \mu \mathrm{m}$ (FIG.14C).

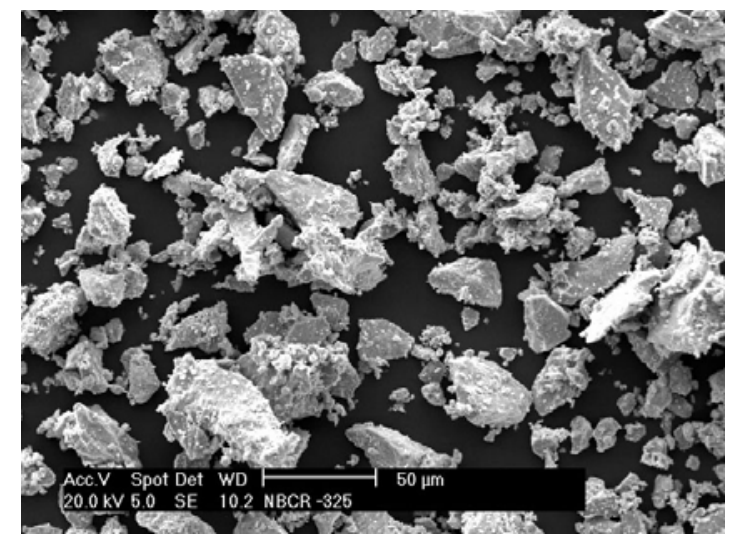

A - como recebido

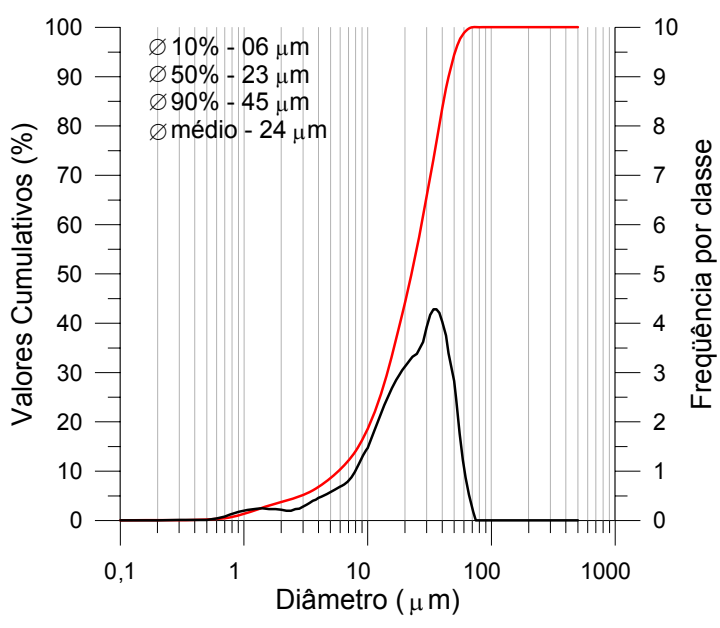

C - como recebido

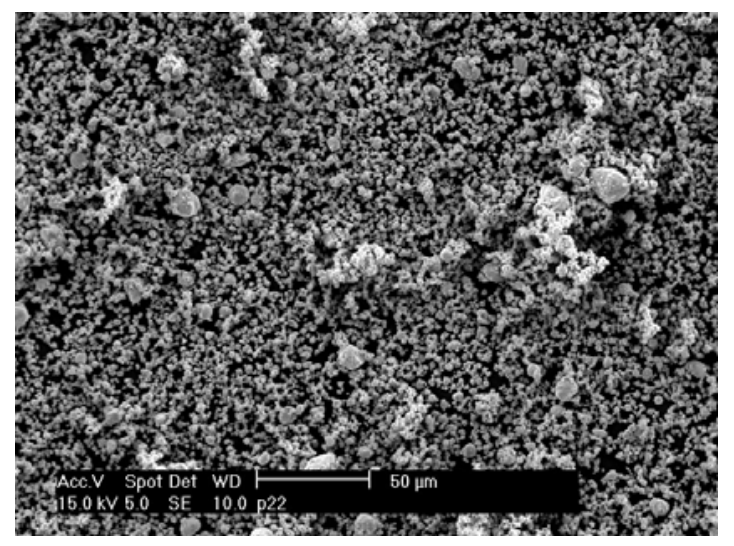

B - pré-ativado

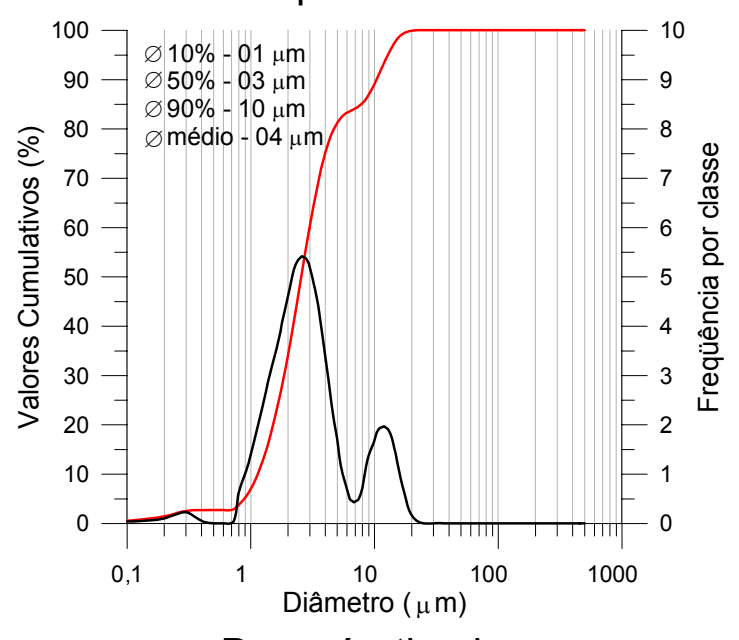

D - pré-ativado

FIGURA 14 - Micrografias e distribuições de tamanho de partículas do nióbio nas condições como recebida e pré-ativada. 


\subsubsection{DIFRAÇÃO DE RAIOS X}

Neste primeiro conjunto de experimentos, somente os pós pré-ativados (PA) e recozidos (PA-R) foram analisados por difração de raios $X$. Os difratogramas experimentais e os calculados pelo método de Rietveld estão apresentados nas FIG.15 e 16.

O difratograma do alumínio pré-ativado apresentou apenas os picos relativos à estrutura cúbica de face centrada $(\mathrm{A} 1-\mathrm{Fm} 3 \mathrm{~m})$ do alumínio. $\mathrm{O}$ parâmetro de rede obtido no refinamento foi de $4,04908 \AA$, muito próximo do valor de 4,0494 $\AA$ fornecido pela referência adotada (Ficha ICSD\#64700). Após o recozimento, o difratograma apresentou os picos relativos ao alumínio e, também, à fase $\mathrm{Al}_{4} \mathrm{C}_{3}$ (romboédrica - R-3mH - Ficha ICSD\#66751). O parâmetro de rede do alumínio obtido após o recozimento foi de 4,05156 A. A fração volumétrica da fase $\mathrm{Al}_{4} \mathrm{C}_{3}$ foi de $11 \pm 1 \%$.

A formação de carboneto de alumínio durante recozimento indica que o ACP se decompôs, disponibilizando carbono. Essa decomposição pode ter ocorrido tanto durante o ciclo de recozimento quanto durante a moagem. $O$ fato de não ter ocorrido aumento do parâmetro de rede no alumínio pré-ativado permite afirmar somente que não houve a formação de solução sólida intersticial. Streletskii et al.(2006) e Enayati et al.(2007) em estudo sobre a moagem com alta energia do sistema Al-C, com 15\% e 30\% de carbono, observaram que, após um certo tempo de moagem, os picos de difração do carbono desapareciam. Ao mesmo tempo, o parâmetro de rede do alumínio se manteve constante para todas as condições de moagem. No caso do alumínio pré-ativado, a decomposição do ACP pode ter possibilitado a formação de agregados muito finos de carbono amorfo e alumínio.

Os resultados de tamanho médio de cristalito e microdeformação apresentados na TAB.5 mostram que a pré-ativação do alumínio produziu uma estrutura nanocristalina. Os valores referentes ao alumínio recozido mostram que, apesar de ter havido um aumento do tamanho de cristalito, o valor de $94 \mathrm{~nm}$ indica que o tratamento de recozimento foi pouco satisfatório. A precipitação do carboneto de alumínio pode ter contribuído para o crescimento limitado do tamanho de cristalito. 

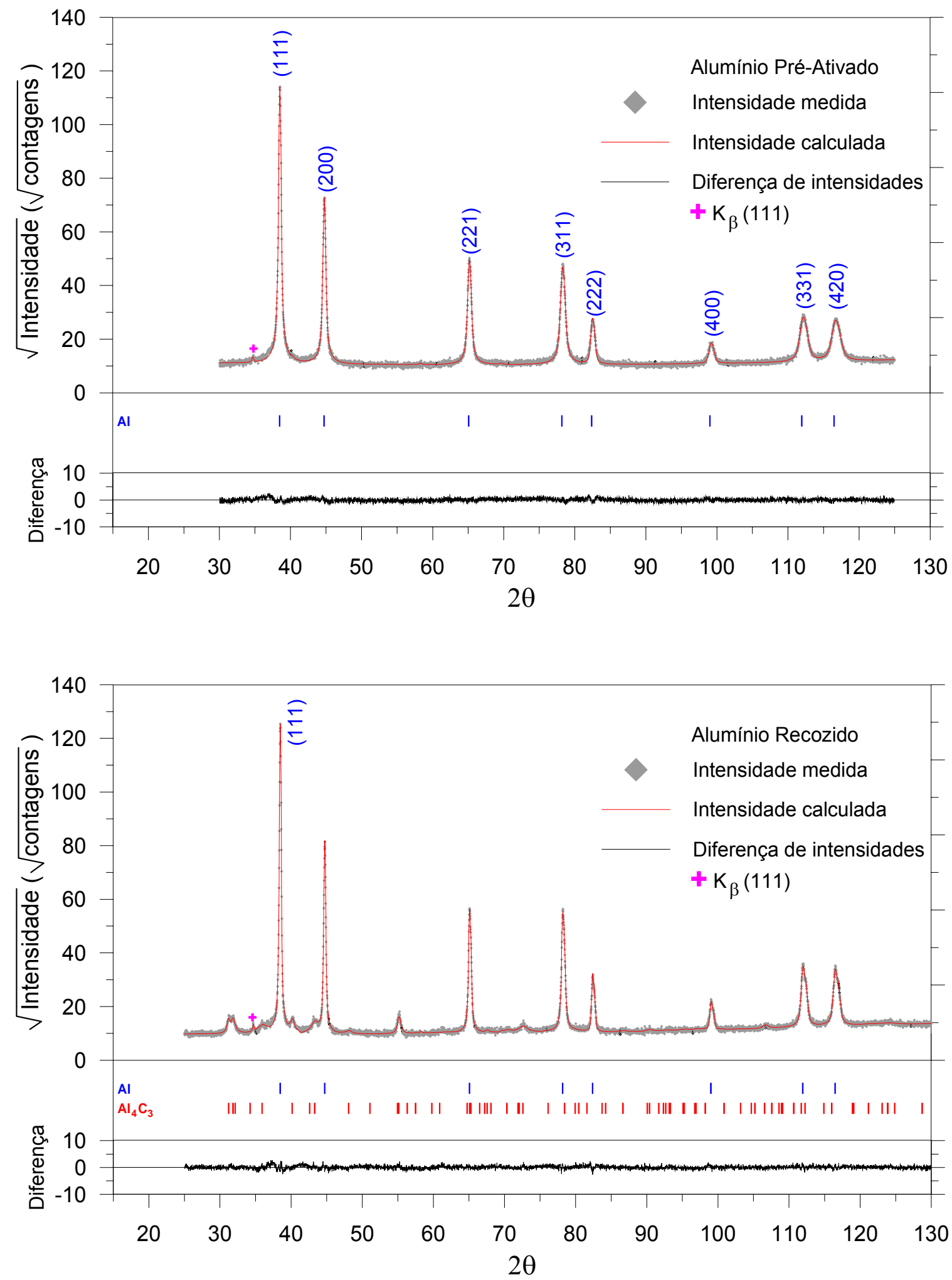

FIGURA 15 - Difratogramas dos pós de alumínio pré-ativado e após tratamento de recozimento, analisados pelo método de Rietveld. 
TABELA 5 - Tamanho de cristalito, microdeformação e parâmetro de rede do alumínio nas condições pré-ativada e recozida.

\begin{tabular}{|c|c|c|c|c|}
\hline \multirow[b]{2}{*}{ Plano } & \multicolumn{2}{|c|}{ Alumínio Pré ativado } & \multicolumn{2}{|c|}{ Alumínio Recozido } \\
\hline & $\begin{array}{l}\text { Tamanho de } \\
\text { cristalito }(\mathrm{nm})\end{array}$ & $\begin{array}{c}\text { Microdeformação } \\
(\%)\end{array}$ & $\begin{array}{l}\text { Tamanho de } \\
\text { cristalito(nm) }\end{array}$ & $\begin{array}{c}\text { Microdeformação } \\
(\%)\end{array}$ \\
\hline 111 & 49,3 & 0,135 & 140,6 & 0,070 \\
\hline 200 & 38,8 & 0,136 & 109,8 & 0,073 \\
\hline 220 & 32,9 & 0,135 & 83,1 & 0,071 \\
\hline 311 & 27,0 & 0,135 & 65,4 & 0,071 \\
\hline 222 & 49,3 & 0,135 & 140,6 & 0,070 \\
\hline 400 & 38,8 & 0,136 & 109,8 & 0,073 \\
\hline 331 & 24,8 & 0,135 & 54,6 & 0,071 \\
\hline 420 & 23,4 & 0,135 & 48,1 & 0,071 \\
\hline Média & 36 & 0,135 & 94 & 0,071 \\
\hline $\begin{array}{l}\text { Desvio } \\
\text { Padrão }\end{array}$ & 10 & 0,001 & 37 & 0,001 \\
\hline $\begin{array}{c}\text { Parâmetro } \\
\text { de rede } \\
(\AA)\end{array}$ & \multicolumn{2}{|c|}{$4,0491 \pm 0,0001$} & \multicolumn{2}{|c|}{$4,05156 \pm 0,00003$} \\
\hline $\mathrm{R}_{\mathrm{wp}}(\%)$ & \multicolumn{2}{|r|}{7,47} & \multicolumn{2}{|r|}{7,58} \\
\hline $\begin{array}{l}\text { Qualidade } \\
\text { de ajuste }\end{array}$ & \multicolumn{2}{|c|}{1,231} & \multicolumn{2}{|r|}{1,211} \\
\hline
\end{tabular}

O difratograma do nióbio pré-ativado apresentou apenas os picos relativos à estrutura cúbica de corpo centrada $(\mathrm{A} 2-\mathrm{Im} 3 \mathrm{~m})$ do nióbio. $\mathrm{O}$ parâmetro de rede obtido no refinamento foi de $3,3291 \AA, 0,67 \%$ maior que o valor de $3,3068 \AA$ fornecido pela referência adotada (Ficha ICSD\#44380). Após o recozimento, o difratograma apresentou os picos relativos ao nióbio e também a presença das fases $\mathrm{Nb}_{2} \mathrm{C}$ (romboédrica - P-3m1 - Ficha ICSD\#43670) e NbO (cúbica - Pm-3m - Ficha ICSD\#14338). O parâmetro de rede do nióbio obtido após o recozimento foi de $3,3020 \AA$. As frações volumétricas das fases $\mathrm{Nb}_{2} \mathrm{C}$ e $\mathrm{NbO}$ foram $11 \pm 1 \% \mathrm{e}$ $4 \pm 1 \%$, respectivamente.

O aumento o parâmetro de rede do nióbio pré-ativado indica que houve a formação de solução sólida intersticial a partir dos produtos de decomposição do ACP. Utilizando a porcentagem de ACP adicionada à mistura e a massa molar do ácido esteárico, foi possível estimar a quantidade máxima de intersticiais fornecida pelo ACP à mistura. A porcentagem atômica total foi de $9,75 \%$, sendo, 
$6,14 \%$ de hidrogênio, 3,25\% de carbono e 0,36\% de oxigênio. Considerando as solubilidades nos sistemas $\mathrm{Nb}-\mathrm{C}, \mathrm{Nb}-\mathrm{O}$ e $\mathrm{Nb}-\mathrm{H}$, o hidrogênio é o elemento mais solúvel $\left(40 \%\right.$ atômico a $\left.171^{\circ} \mathrm{C}\right)$, seguido do oxigênio $\left(1 \%\right.$ atômico a $\left.600{ }^{\circ} \mathrm{C}\right)$ e por último o carbono $\left(0,077 \%\right.$ atômico a $\left.310^{\circ} \mathrm{C}\right)$. O efeito do hidrogênio no parâmetro de rede do nióbio pode ser estimado a partir da seguinte relação: $\Delta \mathrm{a} / \mathrm{a}=0,000472 / \mathrm{CH}$, onde $\mathrm{CH}$ é a concentração atômica de hidrogênio (Alefeld e Völkl, 1978). A partir do teor de hidrogênio calculado acima, obtém-se um parâmetro de rede de $3,3322 \AA$, muito próximo do parâmetro refinado do nióbio pré-ativado (3,3291 $\AA$ ). Esses dados, portanto, sugerem que o hidrogênio seja o responsável mais provável pela alteração do parâmetro de rede.

O oxigênio e o carbono também podem ter contribuído para o aumento do parâmetro de rede do nióbio. Entretanto, a baixa concentração de oxigênio na molécula do ácido esteárico e a baixa solubilidade do carbono no nióbio sugerem que o hidrogênio tenha produzido o maior efeito. Outro dado que reforça a absorção do hidrogênio é o comportamento da pressão do sistema de vácuo durante o ciclo de aquecimento do recozimento. A partir de $320^{\circ} \mathrm{C}$, a pressão aumenta gradativamente até atingir um máximo a $350^{\circ} \mathrm{C}$ e voltar a diminuir com a continuidade do aquecimento, caracterizando a liberação de gases. Esta temperatura está próxima da obtida por Portnoy et al. (2000), para o pico de liberação de hidrogênio $\left(340^{\circ} \mathrm{C}\right)$ durante tratamento térmico posterior à moagem com alta energia. Nesse estudo sobre a formação de hidretos de nióbio durante a moagem com alta energia, os autores observaram a absorção de hidrogênio pelo nióbio após 20 minutos de moagem sob atmosfera de hidrogênio sob pressão de 170 torr. Ainda nesse estudo, formações de uma solução sólida de hidrogênio e oxigênio e de um oxihidreto do tipo $\mathrm{Nb}(\mathrm{OH})$ foram constatadas em moagem de nióbio na presença de água.

A quantidade de $\mathrm{NbO}$ determinada após o recozimento (4\% em volume) indica que, a maior parte do oxigênio consumida na formação do óxido, veio de outras fontes. As possíveis fontes de contaminação de oxigênio ainda estão sob investigação. A formação de $\mathrm{Nb}_{2} \mathrm{C}$ é compatível com o teor de carbono no ácido esteárico, porém, não foi possível determinar se o mesmo entrou em solução sólida. 
Os resultados de tamanho médio de cristalito e microdeformação apresentados na TAB.6 mostram que a pré-ativação do nióbio, assim como no alumínio, produziu uma estrutura nanocristalina. Entretanto, o tamanho de cristalito de 6,6 nm é consideravelmente menor que o valor de $36 \mathrm{~nm}$ obtido para o alumínio. A microdeformação também foi mais intensa que a obtida no alumínio. O tratamento de recozimento do nióbio também foi mais eficiente que no caso do alumínio, produzindo uma microestrutura com uma densidade de defeitos cristalinos muito menor.

O alargamento dos picos de Bragg está relacionado com a extensão do volume da amostra que difrata coerentemente o feixe de raios $X$ incidente. Essa coerência de difração é afetada por distorções na rede cristalina provocadas por microtensões causadas pela presença de defeitos cristalinos como átomos substitucionais ou intersticiais, soluções sólidas, lacunas, discordâncias, maclas e falhas de empilhamento. No caso de materiais particulados ultrafinos ou plasticamente deformados, a probabilidade de ocorrência de pequenas desorientações cristalográficas entre partículas ou subgrãos, aumenta consideravelmente provocando um aumento da intensidade difratada para valores inferiores e superiores ao ângulo de Bragg. Esses dois fenômenos são comumente denominados de alargamento por aumento da microdeformação e alargamento por diminuição do tamanho de cristalito. Há um grande esforço por parte de dezenas de pesquisadores de diversas instituições em modelar matematicamente os efeitos dos defeitos cristalinos sobre o padrão de difração. Entretanto, nos diversos programas disponíveis que utilizam com base o método de Rietveld, há problemas de correlação entre os parâmetros refinados que podem limitar a validade dos resultados de um refinamento. Há várias estratégias para minimizar as correlações, porém, na maior parte dos refinamentos essas estratégias limitam a qualidade de ajuste do difratograma. Neste sentido, os resultados de tamanho médio de cristalito e microdeformação apresentados não só nas TAB.5 e TAB.6, mas também nas demais tabelas, devem ser considerados semi-quantitativos, haja vista que não foi possível, neste trabalho, a verificação desses valores por microscopia eletrônica de transmissão. 

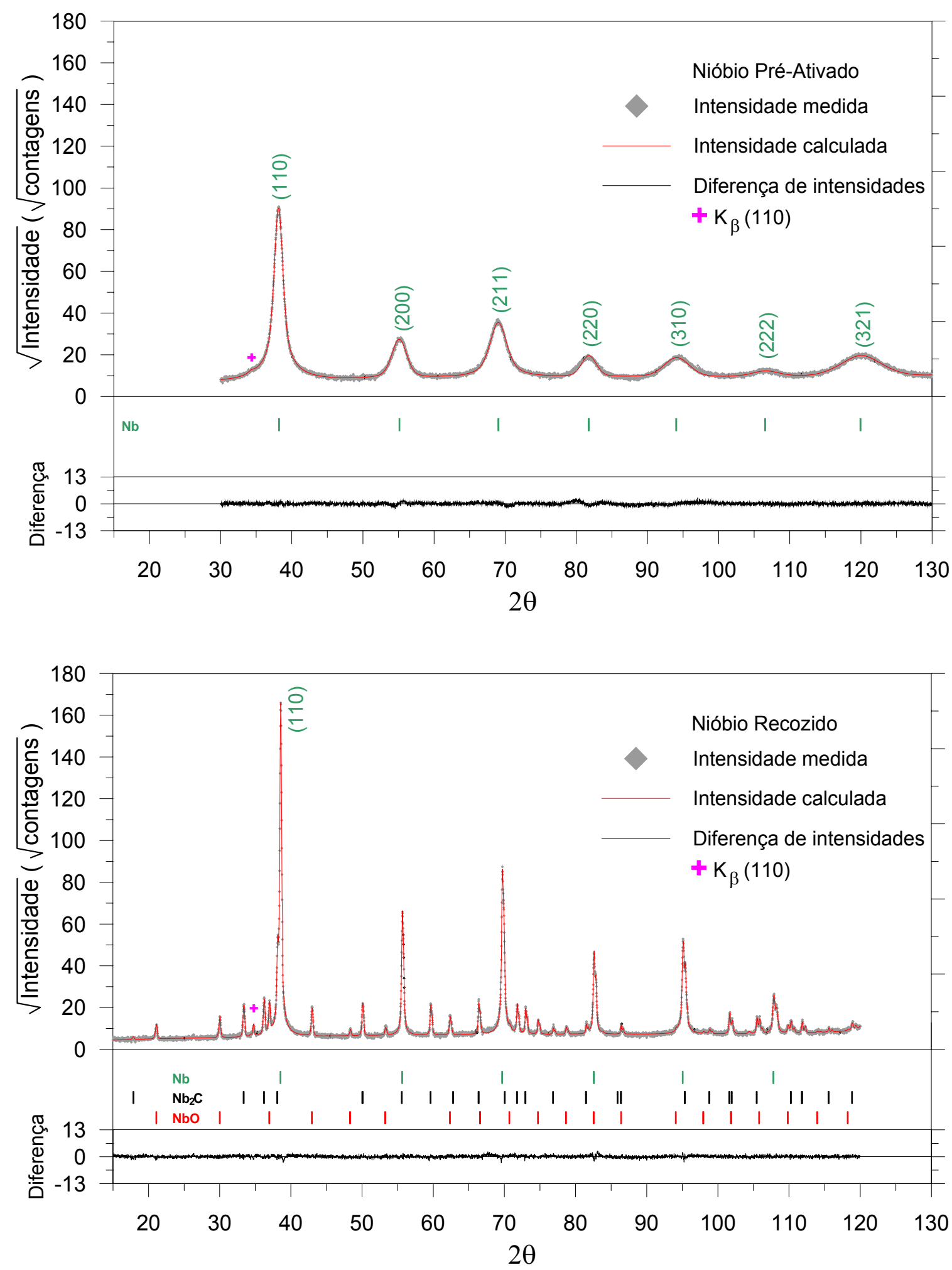

FIGURA 16 - Difratogramas dos pós de nióbio pré-ativado e após tratamento de recozimento, analisados pelo método de Rietveld.. 
TABELA 6 - Tamanho de cristalito, microdeformação e parâmetro de rede do nióbio nas condições pré-ativada e recozida.

\begin{tabular}{|c|c|c|c|c|}
\hline \multirow[b]{2}{*}{ Plano } & \multicolumn{2}{|c|}{ Nióbio Pré ativado } & \multicolumn{2}{|c|}{ Nióbio Recozido } \\
\hline & $\begin{array}{l}\text { Tamanho de } \\
\text { cristalito }(\mathrm{nm})\end{array}$ & $\begin{array}{c}\text { Microdeformação } \\
(\%)\end{array}$ & $\begin{array}{l}\text { Tamanho de } \\
\text { cristalito(nm) }\end{array}$ & $\begin{array}{c}\text { Microdeformação } \\
(\%)\end{array}$ \\
\hline 110 & 10,6 & 0,70 & 199 & 0,035 \\
\hline 200 & 7,1 & 0,93 & 192 & 0,030 \\
\hline 211 & 5,8 & 0,70 & 123 & 0,035 \\
\hline 220 & 10,6 & 0,70 & 199 & 0,035 \\
\hline 310 & 4,2 & 0,85 & 98 & 0,032 \\
\hline 222 & 3,5 & 0,60 & 98 & 0,036 \\
\hline 321 & 4,1 & 0,70 & 109 & 0,035 \\
\hline Média & 6,6 & 0,74 & 145 & 0,034 \\
\hline $\begin{array}{l}\text { Desvio } \\
\text { Padrão }\end{array}$ & 3,0 & 0,11 & 49 & 0,002 \\
\hline $\begin{array}{l}\text { Parâmetro } \\
\text { de rede } \\
(\AA)\end{array}$ & \multicolumn{2}{|c|}{$3,3291 \pm 0,0002$} & \multicolumn{2}{|c|}{$3,30196 \pm 0,00002$} \\
\hline $\mathrm{R}_{\mathrm{wp}}(\%)$ & \multicolumn{2}{|r|}{7,22} & \multicolumn{2}{|r|}{8,21} \\
\hline $\begin{array}{l}\text { Qualidade } \\
\text { de ajuste }\end{array}$ & \multicolumn{2}{|c|}{1,238} & \multicolumn{2}{|r|}{1,201} \\
\hline
\end{tabular}

\subsubsection{PERFIS DE TEMPERATURA}

\section{Misturas do tipo SCR, SPA e SPA-R}

Os perfis de temperatura das pastilhas preparadas com misturas como recebidas (SCR), pré-ativadas (SPA) e pré-ativadas e recozidas (SPA-R) estão apresentados nas FIG.17A, FIG.17C e FIG.17E. Os perfis originalmente obtidos em função do tempo foram rearranjados em função da temperatura do forno com o intuito de minimizar o efeito de pequenas variações da taxa de aquecimento programada. Na TAB.7 estão apresentados os resultados relativos à análise dos perfis. Optou-se ainda por analisar as variações de temperatura da pastilha utilizando o gráfico da diferença de temperatura entre a pastilha e o forno em função da temperatura do forno, como apresentado nas FIG.17B, FIG.17D e FIG17F. Neste caso, o comportamento térmico padrão esperado para uma pastilha sem reações endotérmicas ou exotérmicas é exemplificado pela faixa cinza apresentada junto às curvas. Antes do reaquecimento e após o término da 
desgaseificação, a pastilha apresenta uma temperatura um pouco superior à do forno em razão da diferença de posicionamento dos termopares. Com o reaquecimento essa diferença diminui devido à inércia térmica do sistema que envolve a pastilha. Após o estabelecimento de um gradiente térmico compatível com a condutibilidade térmica do sistema, o equilíbrio do fluxo de calor é estabelecido e a pastilha volta a apresentar uma temperatura um pouco superior ao forno. Note-se que esses gráficos estão truncados no eixo das ordenadas na faixa de $150^{\circ} \mathrm{C}$, em razão da ampliação da escala.

Ao final da desgaseificação a diferença de temperatura entre forno e pastilha nas misturas de reagentes como recebidos (SCR) foi da ordem de $6{ }^{\circ} \mathrm{C}$. O primeiro evento após o início do reaquecimento é a fusão do alumínio, identificado pela diminuição da taxa de aquecimento da pastilha. Teoricamente, haveria a formação de um patamar a uma temperatura de $660^{\circ} \mathrm{C}$ até a completa fusão do alumínio. Entretanto, as dificuldades de se manter um bom contato entre o termopar e a pastilha, associado à existência de um gradiente térmico de aquecimento na pastilha, produz uma inclinação nesse patamar com temperaturas diferentes de início e de fim do processo de fusão. A movimentação do alumínio líquido pode melhorar o contato com o termopar, provocando reduções de temperatura durante a rampa de fusão. Ao término da fusão ocorre um rápido aquecimento da pastilha devido ao gradiente térmico estabelecido entre o forno (cujo aquecimento foi mantido durante o processo de fusão do alumínio) e a pastilha, e um ajuste gradativo da taxa de aquecimento da pastilha compatível com a do forno. O próximo evento térmico é a reação de síntese do composto. A taxa de aquecimento da pastilha se eleva gradativamente até atingir um valor máximo. Após atingir a temperatura de combustão, a pastilha perde calor até atingir o equilíbrio com a temperatura do forno.

A comparação entre os resultados obtidos para as pastilhas SCR e SPA constantes na TAB.7 mostra uma redução da temperatura de ignição de aproximadamente $50^{\circ} \mathrm{C}$ na mistura de reagentes pré-ativados (SPA). Os ganhos de temperatura durante a reação $(\Delta T)$ foram superiores na mistura de reagentes como recebidos (SCR), porém a taxa de aquecimento máxima na mistura SPA foi mais de três vezes superior à apresentada pela mistura SCR. 

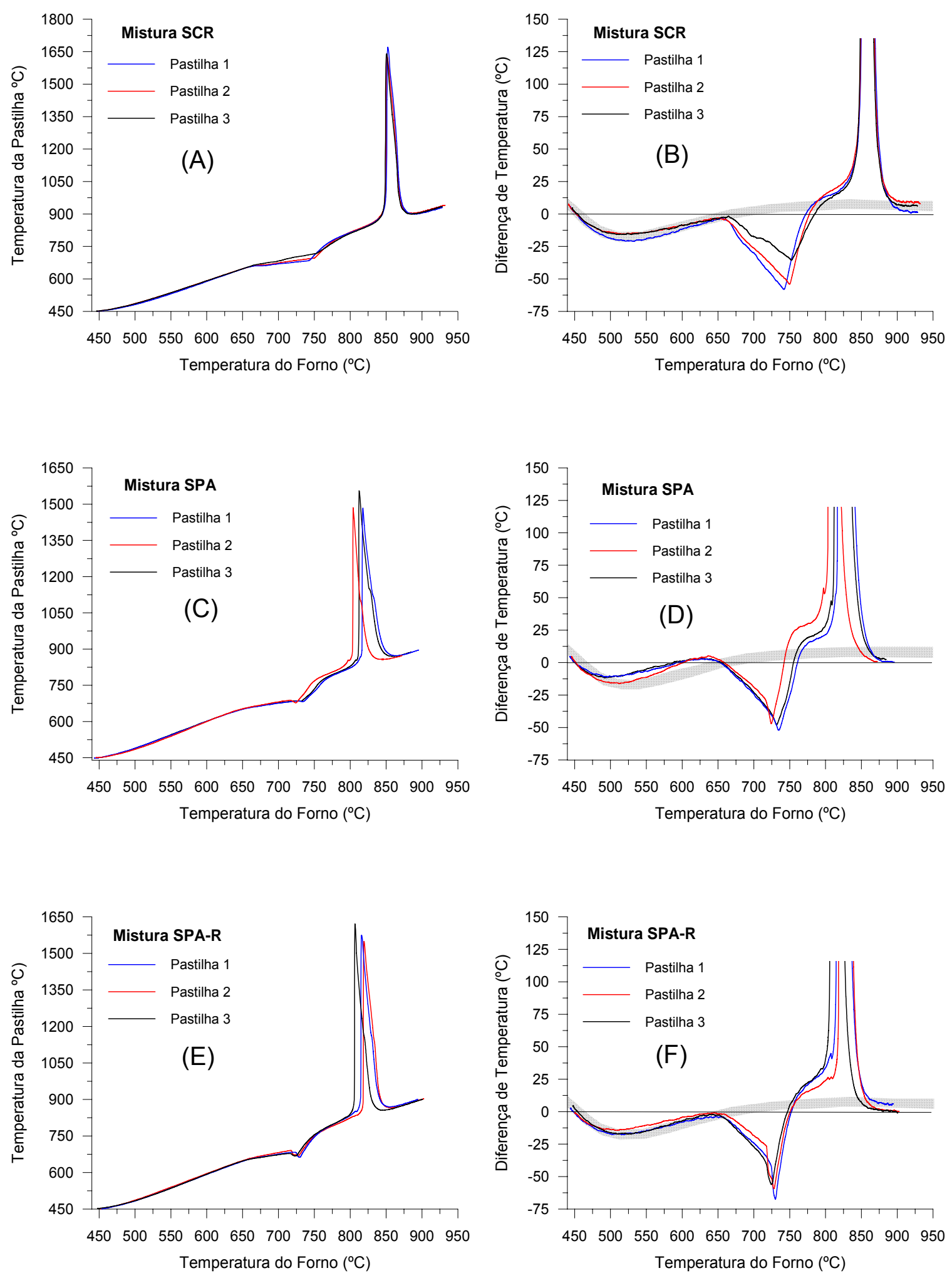

FIGURA 17 - Perfis de temperatura e de diferença de temperatura entre pastilha e forno, referentes às pastilhas preparadas com misturas de reagentes como recebidos, SCR (A e B), pré-ativados, SPA (C e D) e pré-ativados e recozidos, SPA-R (E e F). 
TABELA 7 - Valores característicos dos perfis de temperatura das pastilhas preparadas a partir de misturas de reagentes como recebidos (SCR), pré-ativados (SPA) e pré-ativados e recozidos (SPA-R).

\begin{tabular}{|c|c|c|c|}
\hline & SCR & SPA & SPA-R \\
\hline $\begin{array}{c}\text { Temperatura } \\
\text { de ignição }\left({ }^{\circ} \mathrm{C}\right)\end{array}$ & $878 \pm 4$ & $839 \pm 4$ & $846 \pm 6$ \\
\hline $\begin{array}{c}\text { Temperatura de explosão } \\
\text { térmica }\left({ }^{\circ} \mathrm{C}\right)\end{array}$ & $1071 \pm 24$ & $907 \pm 9$ & $914 \pm 13$ \\
\hline $\begin{array}{l}\text { Temperatura de } \\
\text { Combustão }\left({ }^{\circ} \mathrm{C}\right) \\
\end{array}$ & $1648 \pm 22$ & $1509 \pm 41$ & $1582 \pm 37$ \\
\hline$\Delta \mathrm{T}\left({ }^{\circ} \mathrm{C}\right)$ & $770 \pm 25$ & $669 \pm 40$ & $736 \pm 40$ \\
\hline $\begin{array}{l}\text { Taxa de aquecimento } \\
\text { máxima }\left({ }^{\circ} \mathrm{C} / \mathrm{s}\right)\end{array}$ & $330 \pm 38$ & $1224 \pm 207$ & $1270 \pm 260$ \\
\hline Tempo de reação (s) & $35 \pm 5$ & $22 \pm 3$ & $16 \pm 2$ \\
\hline $\begin{array}{c}\text { Taxa de aquecimento } \\
\text { média }\left({ }^{\circ} \mathrm{C} / \mathrm{s}\right)\end{array}$ & $23 \pm 3$ & $31 \pm 5$ & $46 \pm 2$ \\
\hline $\begin{array}{l}\text { Tempo de fusão do } \\
\text { alumínio (s) }\end{array}$ & $236 \pm 11$ & $208 \pm 10$ & $215 \pm 8$ \\
\hline
\end{tabular}

O tempo de reação menor da mistura de reagentes pré-ativados (SPA) corresponde a uma cinética de reação maior, o que é coerente com a variação da taxa de aquecimento máxima. Entretanto, o aumento da cinética de reação não provocou incremento na temperatura máxima de reação, o que seria esperado devido à menor perda térmica numa reação mais curta. Tal comportamento pode ser explicado mediante a análise dos resultados de difração de raios $X$, que evidenciaram a formação de carbonetos de alumínio e de nióbio nas amostras recozidas em quantidade da ordem de $11 \%$. Tais partículas, se formadas antes da reação, tendem a agir como diluentes térmicos e diminuem a quantidade de reagentes disponíveis para reação, prejudicando a elevação de temperatura.

O princípio da ativação mecânica baseia-se em aumentar a energia armazenada no sistema, diminuindo a energia da ativação necessária para transformações de fase (Boldyrev, 1998). Como exposto nos itens 3.3.2 e 3.3.3, o aumento da quantidade de defeitos cristalinos e o aumento da área de superfície, são os principais mecanismos de ativação. Os resultados apresentados até esse momento indicam um efeito da pré-ativação sobre a cinética de reação e a temperatura de ignição. Como as distribuições de tamanho de partícula do nióbio são diferentes nas condições como recebido e pré-ativado, não é possível creditar os efeitos observados até aqui apenas ao estado encruado dos reagentes. 
A FIG.18 apresenta a comparação das curvas de comportamento térmico referentes às misturas como recebidas (SCR), pré-ativadas (SPA) e recozidas (SPA-R). Uma característica a ser destacada na mistura SPA é a diferença de temperatura entre a pastilha e o forno um pouco antes da fusão do alumínio, que foi levemente superior à apresentada nas misturas SCR e SPA-R. Essa diferença sugere a possibilidade da existência de algum fenômeno exotérmico de baixa intensidade e difuso quanto à temperatura de ocorrência.

A comparação dos resultados apresentados na TAB.7 mostra que a distribuição do tamanho de partícula mais fina é o principal parâmetro responsável pela taxa de aquecimento maior nas misturas SPA. A temperatura de combustão menor da mistura SPA-R é coerente com a constatação da formação de carbonetos de nióbio e alumínio durante o recozimento. Essas partículas atuam como diluentes térmicos, consumindo parte da energia liberada na reação. A similaridade na taxa de aquecimento máxima indica que a presença dos carbonetos antes da reação não afeta de maneira expressiva o mecanismo de reação. Por outro lado, o tempo de reação maior e a temperatura de combustão menor obtidos na mistura SPA em relação à mistura SPA-R, sugere a possibilidade de ocorrência de algum evento endotérmico simultaneamente a reação.
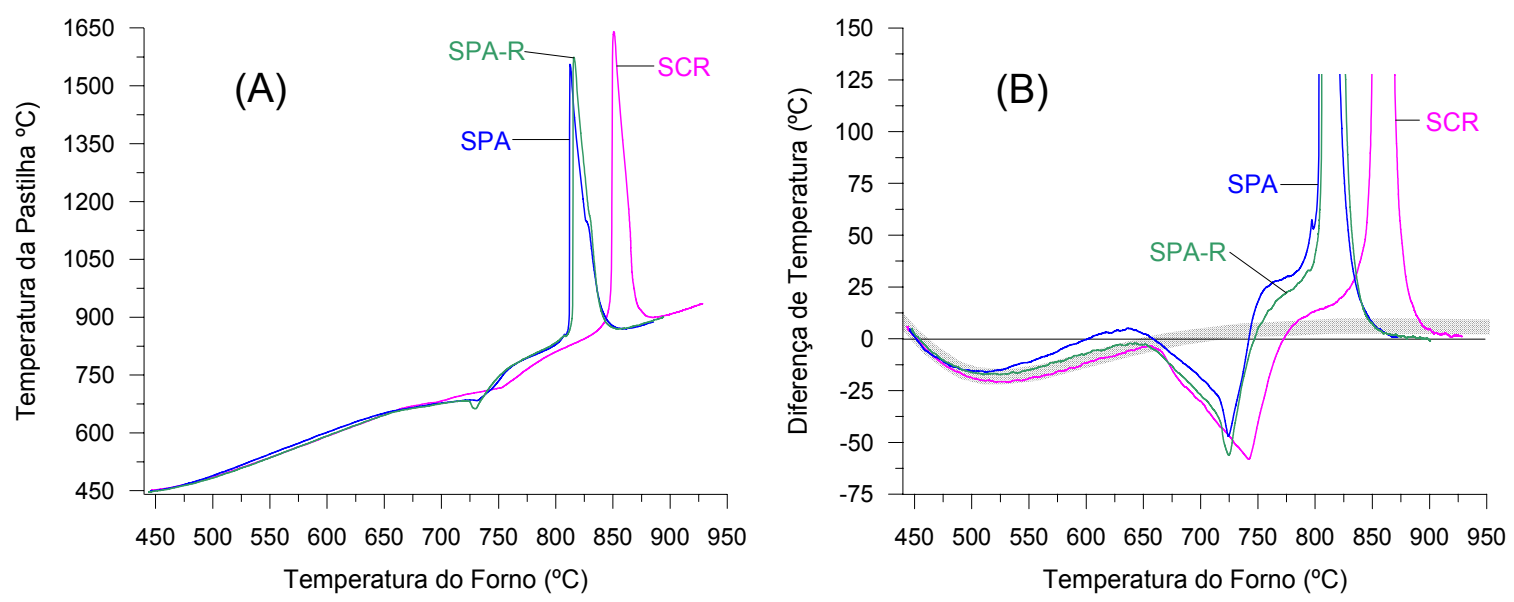

FIGURA 18 - Perfis de temperatura $(A)$ e de diferença de temperatura entre pastilha e forno (B), referentes às pastilhas preparadas com misturas de reagentes como recebidos (SCR), pré-ativados (SPA) e pré-ativados e recozidos, SPA-R. 


\section{Misturas do tipo SPA-A e SPA-N}

Os perfis de temperatura das pastilhas preparadas com misturas de alumínio pré-ativado e nióbio como recebido (SPA-A) e com misturas de alumínio como recebido e nióbio pré-ativado (SPA-N) estão apresentados na FIG.19. Na TAB.8 estão apresentados os resultados obtidos na análise desses perfis, conjuntamente com os resultados das misturas SCR e SPA para fins comparativos.

A diferença mais significativa constatada na comparação dos valores apresentados na TAB.8 diz respeito à taxa de aquecimento. O valor obtido na mistura SPA-A é uma ordem de grandeza inferior $\left(156^{\circ} \mathrm{C} / \mathrm{s}\right)$ ao observado na mistura SPA-N $\left(1748^{\circ} \mathrm{C} / \mathrm{s}\right)$. A maior parte dessa diferença está relacionada ao menor tamanho médio de partícula do nióbio pré-ativado. Entretanto, se forem comparados os valores das misturas como recebidas $\left(330^{\circ} \mathrm{C} / \mathrm{s}\right)$ e pré-ativadas
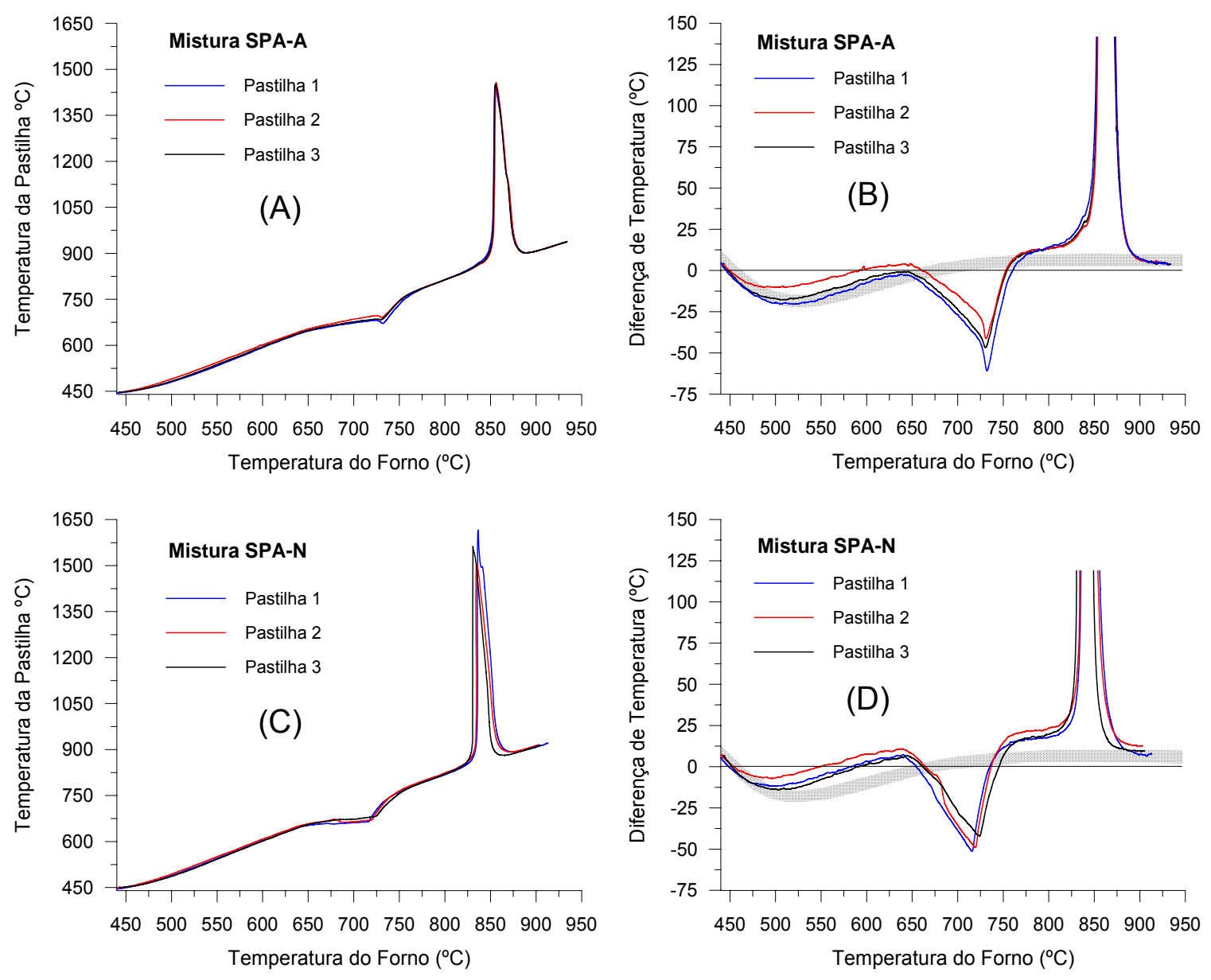

FIGURA 19 - Perfis de temperatura e de diferença de temperatura entre pastilha e forno, referentes às pastilhas preparadas a partir de misturas com apenas o alumínio no estado pré-ativado, SPA-A (A e B), e de misturas com apenas o nióbio no estado pré-ativado, SPA-N (C e D). 
TABELA 8 - Valores característicos dos perfis de temperatura das pastilhas preparadas a partir de misturas com apenas o alumínio no estado pré-ativado (SPA-A) e de misturas com apenas o nióbio no estado pré-ativado (SPA-N). Valores das mistura SCR e SPA apresentados conjuntamente para fins comparativos.

\begin{tabular}{|c|c|c|c|c|}
\hline & SCR & SPA & SPA-A & SPA-N \\
\hline $\begin{array}{c}\text { Temperatura } \\
\text { de ignição }\left({ }^{\circ} \mathrm{C}\right)\end{array}$ & $878 \pm 4$ & $839 \pm 4$ & $875 \pm 3$ & $856 \pm 4$ \\
\hline $\begin{array}{c}\text { Temperatura de } \\
\text { explosão térmica }\left({ }^{\circ} \mathrm{C}\right)\end{array}$ & $1071 \pm 24$ & $907 \pm 9$ & $990 \pm 11$ & $952 \pm 22$ \\
\hline $\begin{array}{l}\text { Temperatura de } \\
\text { Combustão }\left({ }^{\circ} \mathrm{C}\right) \\
\end{array}$ & $1648 \pm 22$ & $1509 \pm 41$ & $1451 \pm 6$ & $1560 \pm 56$ \\
\hline$\Delta \mathrm{T}\left({ }^{\circ} \mathrm{C}\right)$ & $770 \pm 25$ & $669 \pm 40$ & $577 \pm 8$ & $704 \pm 58$ \\
\hline $\begin{array}{l}\text { Taxa de aquecimento } \\
\text { máxima }\left({ }^{\circ} \mathrm{C} / \mathrm{s}\right)\end{array}$ & $330 \pm 38$ & $1224 \pm 207$ & $156 \pm 12$ & $1748 \pm 294$ \\
\hline Tempo de reação (s) & $35 \pm 5$ & $22 \pm 3$ & $39 \pm 3$ & $29 \pm 2$ \\
\hline $\begin{array}{c}\text { Taxa de aquecimento } \\
\text { média }\left({ }^{\circ} \mathrm{C} / \mathrm{s}\right)\end{array}$ & $23 \pm 3$ & $31 \pm 5$ & $15 \pm 1$ & $24 \pm 3$ \\
\hline $\begin{array}{l}\text { Tempo de fusão do } \\
\text { alumínio (s) }\end{array}$ & $236 \pm 11$ & $208 \pm 10$ & $236 \pm 11$ & $202 \pm 10$ \\
\hline
\end{tabular}

$\left(1224^{\circ} \mathrm{C} / \mathrm{s}\right)$ pode-se concluir que a utilização de alumínio como recebido é benéfico à cinética de reação. Uma das variáveis que afeta diretamente a taxa de reação em sistemas que envolvem reagentes no estado líquido é a quantidade de fase líquida e sua capacidade de movimentação. $A$ presença de $\mathrm{Al}_{4} \mathrm{C}_{3}$ no alumínio pré-ativado pode comprometer tanto a quantidade, quanto a movimentação da fase líquida. Na mistura SPA-A, o efeito mais intenso está relacionado com o maior tamanho médio de partícula do nióbio.

\subsubsection{MICROESTRUTURA DAS PASTILHAS}

\section{Pastilhas do tipo SCR e SPA}

A microestrutura das pastilhas foi caracterizada em dois momentos. A análise principal ocorreu após o processo de síntese por reação exotérmica. Outras análises foram realizadas em algumas pastilhas que tiveram seu processo de aquecimento interrompido, instantes antes da ignição da reação. As fases observadas foram identificadas apenas qualitativamente (MEV). A identificação das fases por difração de raios $X$ será realizada futuramente. 
Na FIG.20 estão apresentadas as micrografias de pastilhas preparadas a partir de misturas de reagentes como recebidos (SCR) e de reagentes préativados (SPA). Cada condição apresentada na FIG.20 consiste de duas micrografias, sendo que as da esquerda possuem a mesma ampliação e as da direita um detalhamento da microestrutura com ampliações diversas. As micrografias $\mathrm{C}, \mathrm{D}, \mathrm{G}$ e $\mathrm{H}$ são referentes às pastilhas, cujo aquecimento foi interrompido a $820^{\circ} \mathrm{C}$, momentos antes da reação exotérmica.

A microestrutura da pastilha SCR reagida é composta de uma matriz porosa formada pelo intermetálico $\mathrm{NbAl}_{3}$ (tonalidade cinza clara) e uma estrutura eutética formada de $\mathrm{Nb}_{2} \mathrm{Al}$ e $\mathrm{NbAl}_{3}$ (tonalidade branca) com dispersão mais concentrada próxima à superfície da pastilha. A presença do eutético indica que houve desvio de composição para teores menores de alumínio (ver diagrama de equilíbrio na p. 21). A concentração do eutético junto à superfície sugere que pode ter ocorrido perda de alumínio por evaporação. Nas pastilha cujo aquecimento foi interrompido (FIG.20C e D) observou-se que há formação de $\mathrm{NbAl}_{3}$ por difusão antes da temperatura de ignição.

A microestrutura da pastilha SPA reagida (FIG.20E e F) é composta de uma matriz porosa formada pelo intermetálico $\mathrm{NbAl}_{3}$ (tonalidade cinza clara), partículas com alta concentração de nióbio e carbono (tonalidade branca) e partículas com alta concentração de alumínio e oxigênio (tonalidade cinza escuro). A composição química das partículas, embora qualitativa, sugere que as partículas brancas sejam carbonetos, $\mathrm{Nb}_{2} \mathrm{C}$, identificados também no nióbio recozido, e as partículas escuras sejam óxidos, $\mathrm{Al}_{2} \mathrm{O}_{3}$. A possível ausência das fases $\mathrm{NbO}$ e $\mathrm{Al}_{4} \mathrm{C}_{3}$ (ainda não confirmada) é uma indicação de que possa ter ocorrido uma reação entre essas duas fases, ativada pela liberação de calor da combustão. Essas fases não foram observadas na microestrutura da pastilha SCR (FIG.20A e B). A microestrutura da pastilha SPA reagida apresentou uma porosidade melhor distribuída em relação à pastilha SCR reagida, provavelmente em razão da grande quantidade de óxidos e de carbonetos na matriz. As ausências do eutético $\mathrm{Nb}_{2} \mathrm{Al}+\mathrm{NbAl}_{3}$ e de alumínio não reagido, indicam que a composição manteve a estequiometria e que a formação de óxidos e de carbonetos consumiu praticamente a mesma quantidade de alumínio e de nióbio.

$\mathrm{Na}$ pastilha SPA, cujo aquecimento foi interrompido, a microestrutura é formada por uma matriz cinza (alumínio) com partículas brancas dispersas (nióbio). 


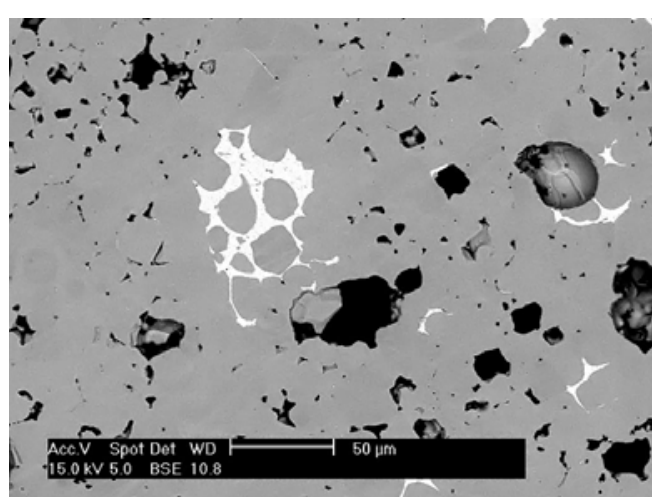

(A) SCR reagida

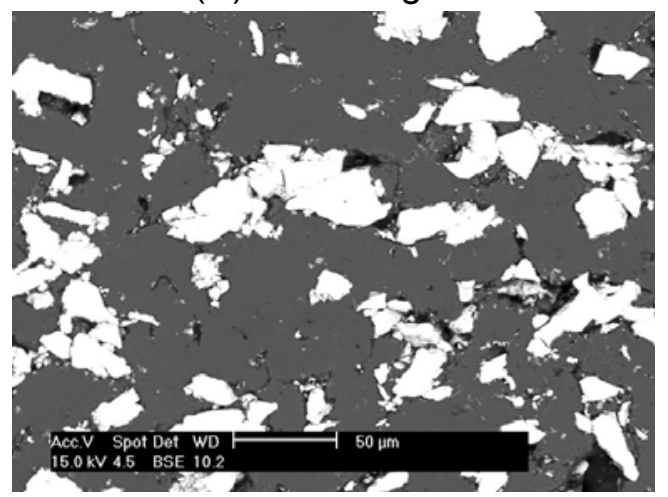

(C) SCR antes da reação

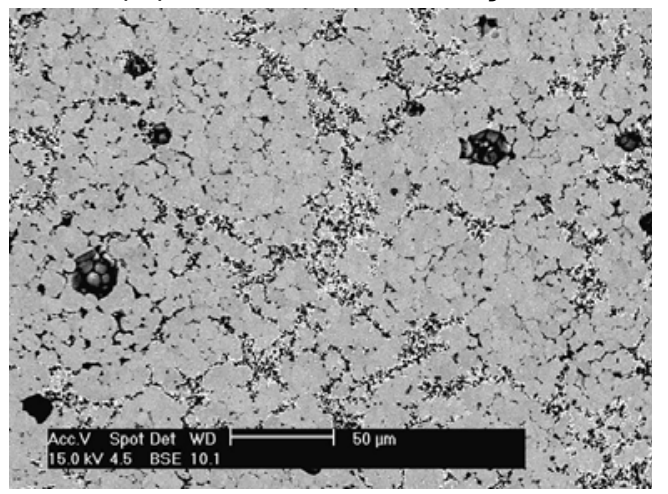

(E) SPA reagida

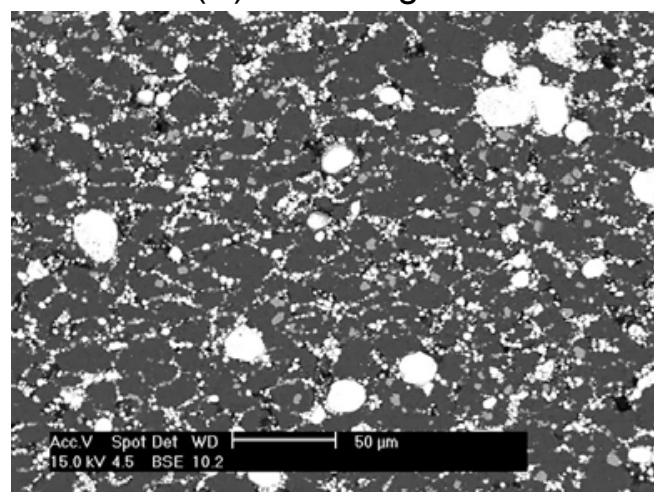

(G) SPA antes da reação

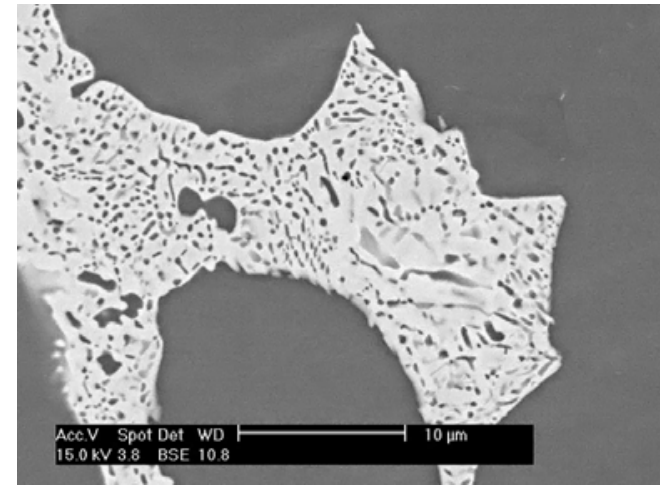

(B) SCR reagida

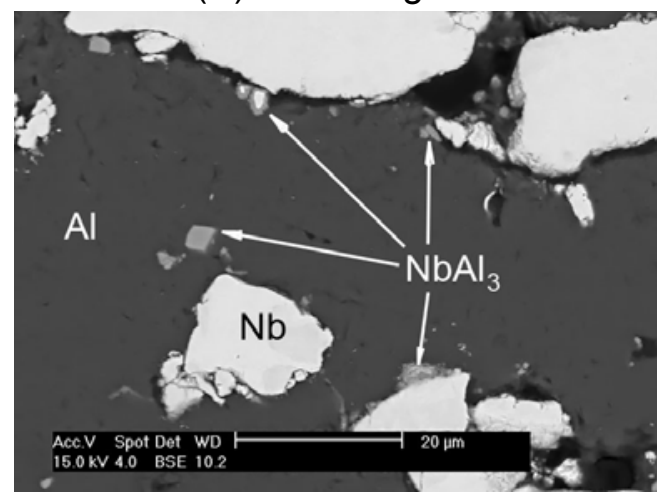

(D) SCR antes da reação

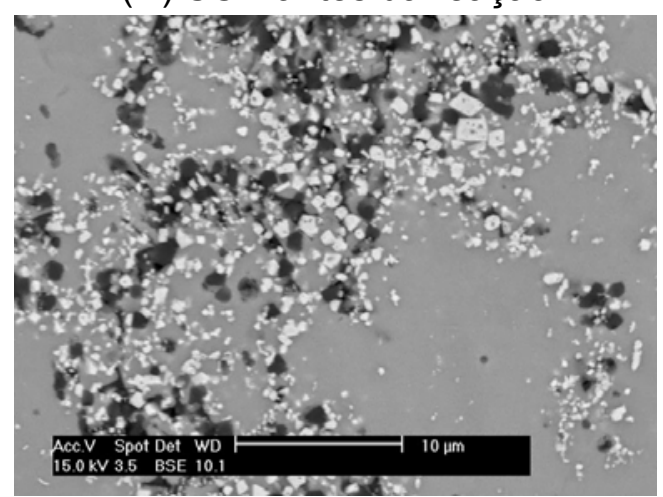

(F) SPA reagida

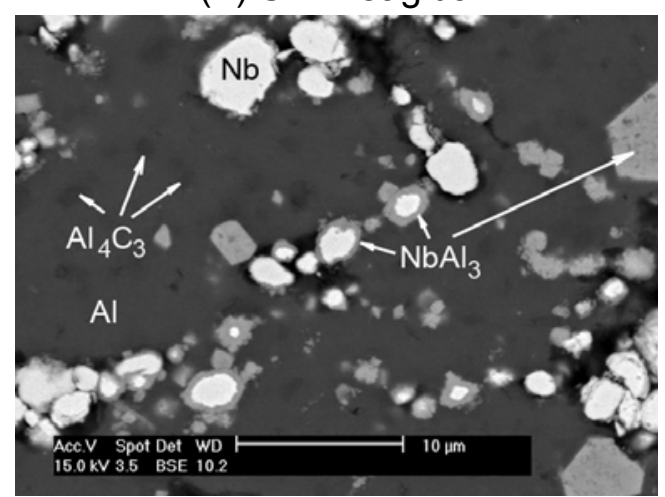

(H) SPA antes da reação

FIGURA 20 - Micrografias de pastilhas reagidas e de pastilhas com interrupção de aquecimento antes da ignição, referentes às misturas de reagentes como recebidos (SCR) e de reagentes pré-ativados (SPA). Microscopia eletrônica de varredura com imagem de elétrons retroespalhados. 
Observou-se que há formação de $\mathrm{NbAl}_{3}$ por difusão antes da temperatura de ignição (FIG.20H), com uma intensidade maior que a observada na pastilha SCR (FIG.20D). A micrografia $\mathrm{H}$ evidencia ainda regiões mais escuras na matriz de alumínio, situação não observada na pastilha SCR. Tais regiões provavelmente estão associadas à precipitação de carbonetos de alumínio $\left(\mathrm{Al}_{4} \mathrm{C}_{3}\right)$ formados durante o aquecimento.

\section{Pastilhas do tipo SPA-A e SPA-N}

A FIG.21 apresenta as micrografias de pastilhas preparadas a partir de misturas do tipo SPA-A (alumínio pré-ativado e nióbio como recebido) e SPA-N (alumínio como recebido e nióbio pré-ativado). As pastilhas SPA-A apresentaram um forte inchamento após o ciclo de reação e praticamente não houve sinterização das partículas de $\mathrm{NbAl}_{3}$. A falta de sinterização provocou o colapso das pastilhas. As microestruturas apresentadas na FIG.21A e B são do pó das pastilhas SPA-A reagidas após colapsarem. A FIG.21B mostra uma partícula de nióbio não reagido com $\mathrm{NbAl}_{3}$ ao redor e uma fina camada de $\mathrm{Nb}_{2} \mathrm{Al}$ separando o nióbio do $\mathrm{NbAl}_{3}$. Essa situação indica uma baixa difusão de alumínio pela a camada de $\mathrm{NbAl}_{3}$, situação que favorece a nucleação de $\mathrm{Nb}_{2} \mathrm{Al}$. Essa baixa difusão pode ter ocorrido por falta de fase líquida (Al). A baixa velocidade de reação observada nessa pastilha (ver TAB.8) indica que o processo de reação foi controlado por difusão no estado sólido, no caso, pela difusão de alumínio no $\mathrm{NbAl}_{3}$. Esse mecanismo provoca o inchamento da pastilha devido à variação de volume molar entre o nióbio e o $\mathrm{NbAl}_{3}$.

As micrografias C e D da FIG.21 (SPA-A) são da pastilha que sofreu interrupção no aquecimento. Nota-se na matriz de alumínio a presença de regiões escuras provavelmente relacionadas com a formação de $\mathrm{Al}_{4} \mathrm{C}_{3}$. $A$ presença desses carbonetos na fase líquida pode ter diminuído a quantidade de fase líquida, limitando o mecanismo de dissolução-reprecipitação, característico de altas velocidades de reação.

A microestrutura da pastilha SPA-N reagida apresentou forte heterogeneidade. Algumas regiões apresentaram a formação do eutético $\mathrm{Nb}_{2} \mathrm{Al}+\mathrm{NbAl}_{3}$ e outras apresentaram alumínio não reagido. Essa situação indica que houve macrossegregação dos reagentes que, provavelmente, tenha sido provocada pelo arraste das partículas finas de nióbio pré-ativado pelo alumínio líquido. $A$ pastilha que sofreu interrupção no aquecimento (FIG.21G e H) evidencia uma microssegregação das partículas de nióbio, porém a possível macrossegregação não ocorreu até a temperatura de interrupção do tratamento. 


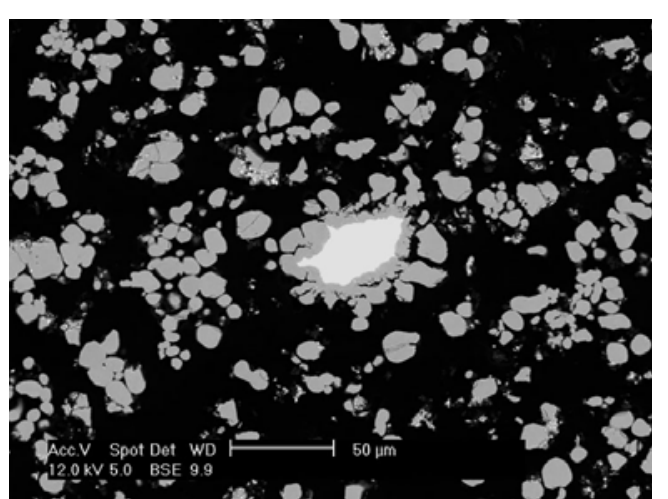

(A) SPA-A reagida

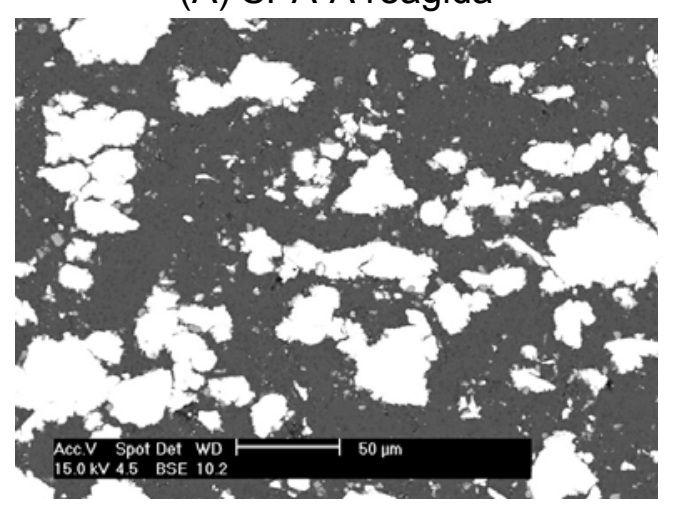

(C) SPA-A antes da reação

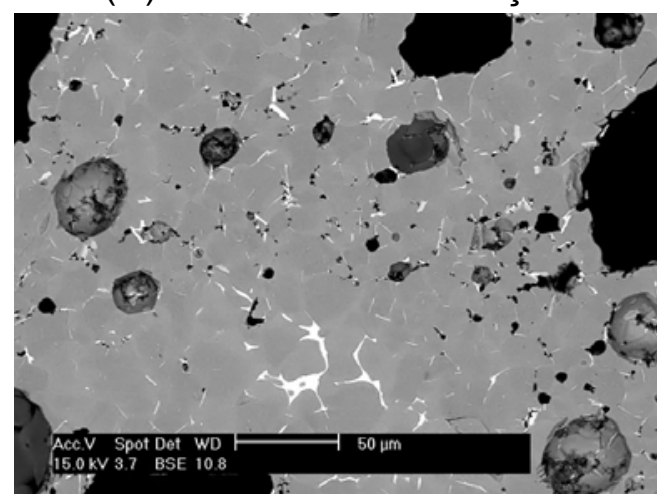

(E) SPA-N reagida

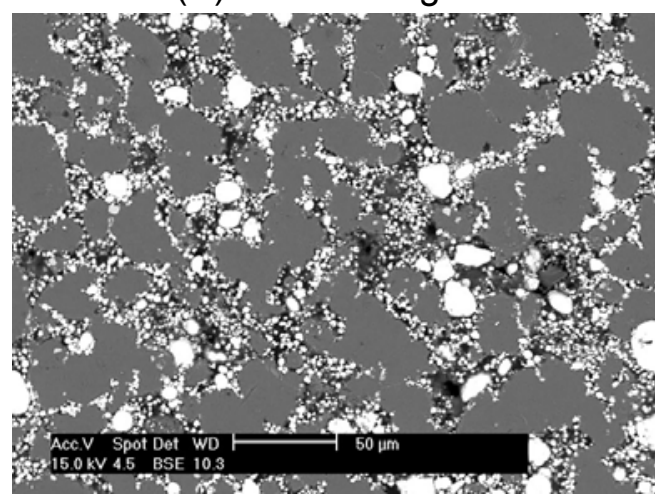

(G) SPA-N antes da reação

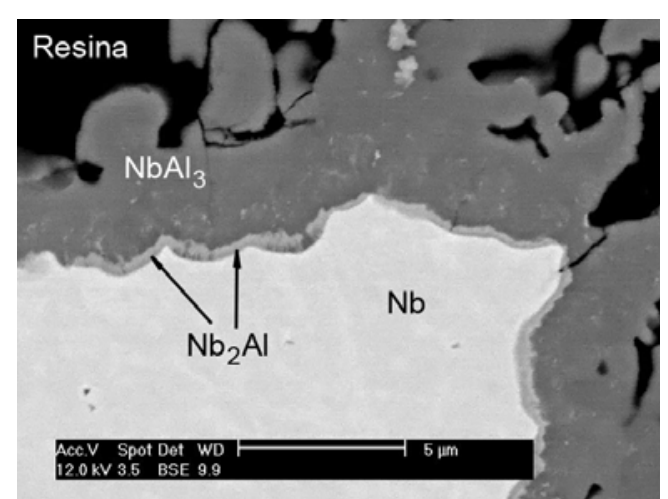

(B) SPA-A reagida

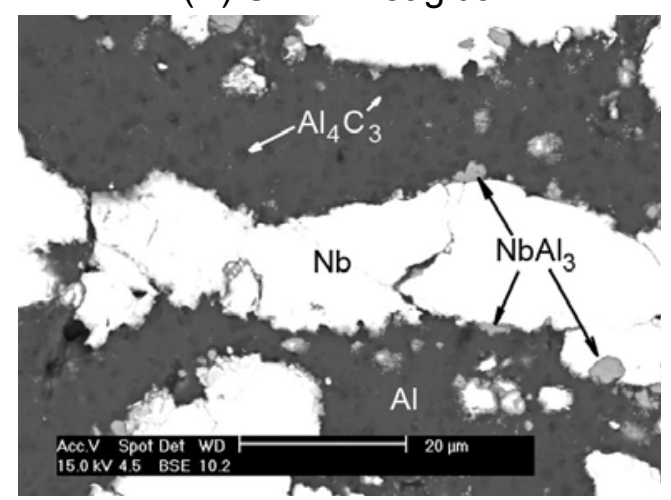

(D) SPA-A antes da reação

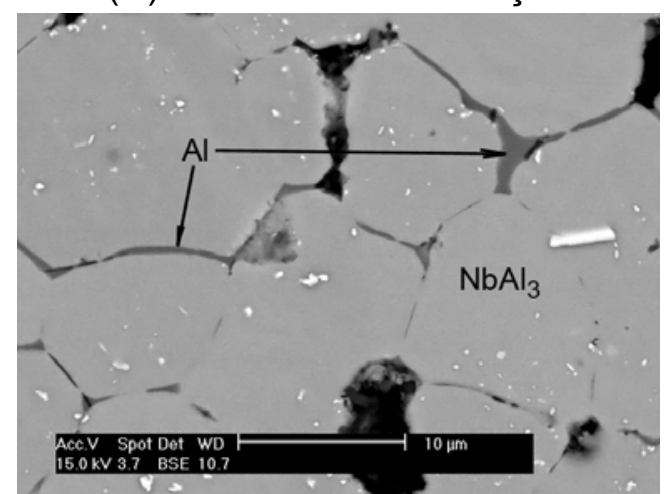

(F) SPA-N reagida

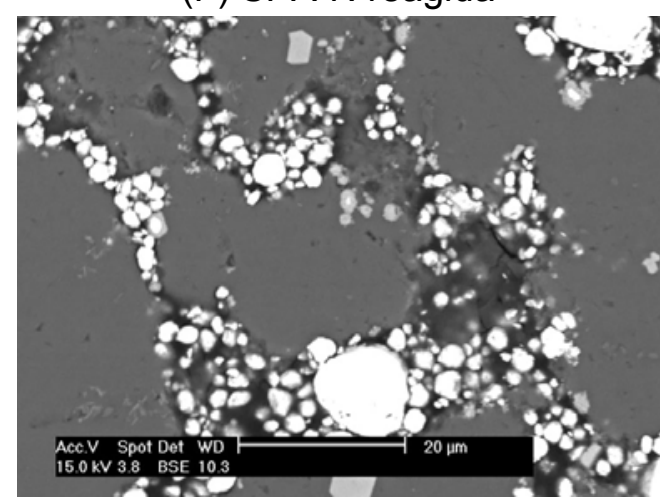

(H) SPA-N antes da reação

FIGURA 21 - Micrografias de pastilhas reagidas e de pastilhas com interrupção de aquecimento antes da ignição, referentes às misturas com somente alumínio pré-ativado (SPA-A) e com somente nióbio pré-ativado (SPA-N). Microscopia eletrônica de varredura com imagem de elétrons retroespalhados. 


\subsection{MISTURAS MOÍDAS COM 1,9\% DE ACP (M)}

Os resultados obtidos neste primeiro conjunto de experimentos e expostos nos próximos itens permitiram as seguintes constatações:

a. A pré-ativação dos reagentes muda o mecanismo de formação de agregados durante a moagem com alta energia. $O$ agregado foi formado pela incrustação das partículas finas de nióbio nas partículas de alumínio;

b. A capacidade de deformação do nióbio foi o parâmetro que definiu a formação de agregados lamelares;

c. A moagem por 20 minutos de misturas $\mathrm{Nb}_{25} \mathrm{Al}_{75}$ produziu uma estrutura nanocristalina no alumínio com densidade de defeitos cristalinos menor que o verificado no alumínio pré-ativado;

d. A moagem por 120 minutos de misturas $\mathrm{Nb}_{25} \mathrm{Al}_{75}$ produziu uma estrutura nanocristalina no alumínio com densidade de defeitos cristalinos equivalente ao alumínio pré-ativado;

e. A moagem por 20 e 120 minutos de misturas $\mathrm{Nb}_{25} \mathrm{Al}_{75}$ produziu uma estrutura nanocristalina no nióbio com densidade de defeitos cristalinos menor que o verificado no alumínio pré-ativado;

f. As moagens de misturas $\mathrm{Nb}_{25} \mathrm{Al}_{75}$ provocaram um decréscimo nas temperaturas de ignição da faixa entre $840^{\circ} \mathrm{C}$ e $880^{\circ} \mathrm{C}$ para a faixa de temperatura referente à fusão do alumínio. 


\subsubsection{MICROSCOPIA E DISTRIBUIÇÃO GRANULOMÉTRICA}

\section{Misturas MCR, MPA e MPA-R}

As micrografias de pó solto e de pó embutido das misturas moídas a partir de pós como recebidos (MCR) e pré-ativados (MPA) após 20 e 120 minutos de moagem estão apresentadas nas FIG.22 e 23. Todas as micrografias foram feitas utilizando o sinal de elétrons retroespalhados. Por esse motivo, a cor branca caracteriza o nióbio, a cor cinza corresponde ao alumínio. No caso de micrografias de pós embutidos, a matriz escura que envolve as partículas corresponde à resina do embutimento. Na mesma figura estão os resultados de distribuição granulométrica para as moagens com 120 minutos.

A pré-ativação dos reagentes mudou consideravelmente a distribuição dos reagentes após a moagem. Esse efeito foi mais intenso na mistura moída por 20 minutos. No caso da mistura MCR, o tempo curto de moagem provoca o achatamento das partículas, as quais assumem a forma de plaquetas ("flakes"). Esse comportamento é típico de sistemas dúcteis, nos quais as partículas têm grande capacidade de deformação plástica e baixa resistência mecânica. Uma das conseqüências da introdução de defeitos cristalinos durante a pré-ativação, é o aumento da resistência mecânica das partículas pelo mecanismo de encruamento. Essa resistência mais elevada limitou a deformação plástica das partículas pré-ativadas, motivo pelo qual elas mantiveram uma forma mais arredondada. O aumento do tempo de moagem diminui as diferenças tanto de forma como de tamanho. As distribuições granulométricas após 120 minutos de moagem, apresentadas nas FIG.22E e F, mostram-se muito parecidas, embora ainda seja possível observar partículas achatadas na mistura do tipo MCR.

Simultaneamente à deformação das partículas ocorre a formação de agregados de partículas de nióbio e alumínio. As micrografias apresentadas na FIG.23, relativas ao pó embutido das misturas MCR e MPA, mostram que a capacidade de deformação plástica das partículas no início do processo tem influência no tipo de distribuição dos reagentes dentro dos agregados. A formação de plaquetas no início da moagem gera agregados com estrutura lamelar em acordo com o mecanismo proposto por Benjamin e Volin (1974) apresentado no item 3.3. No caso das misturas MPA, a homogeneização da distribuição das 


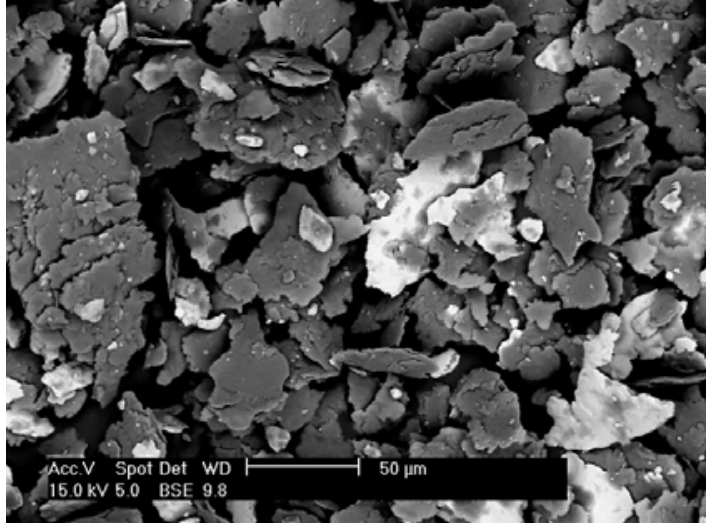

A - 20 minutos - MCR

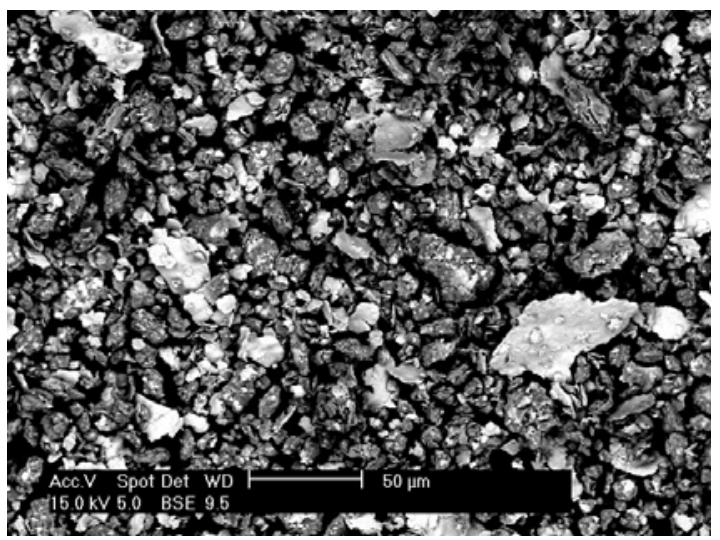

C - 120 minutos - MCR

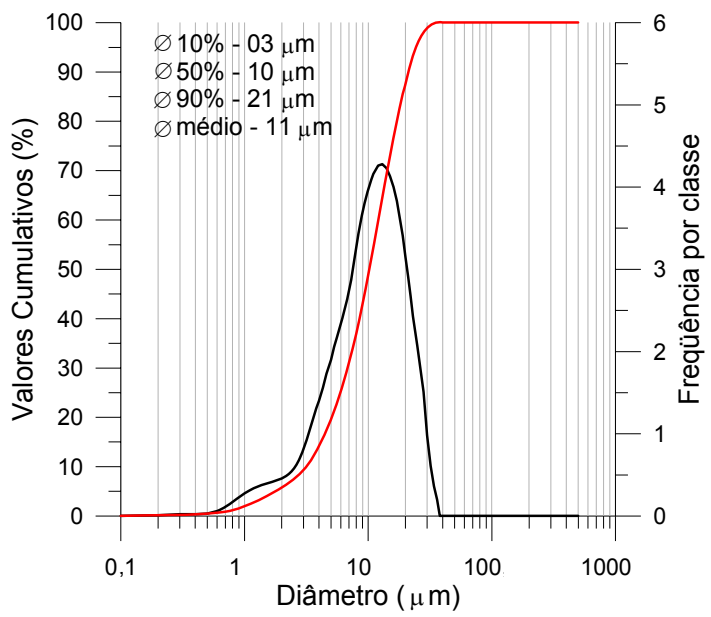

E - 120 minutos - MCR

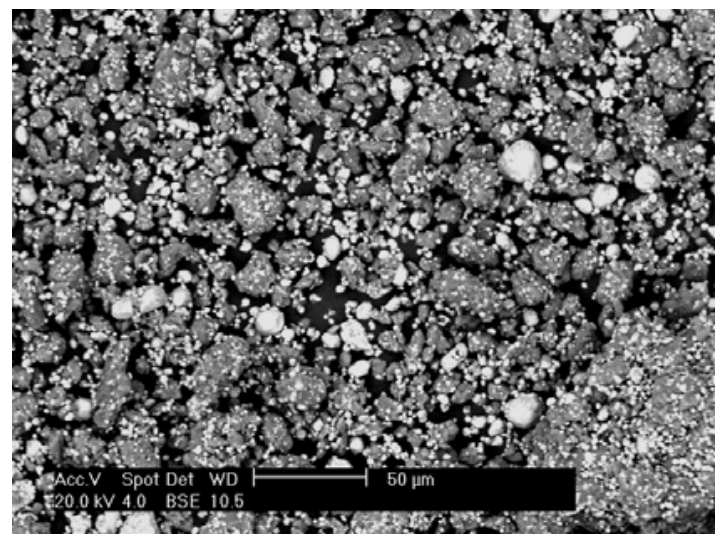

B - 20 minutos - MPA

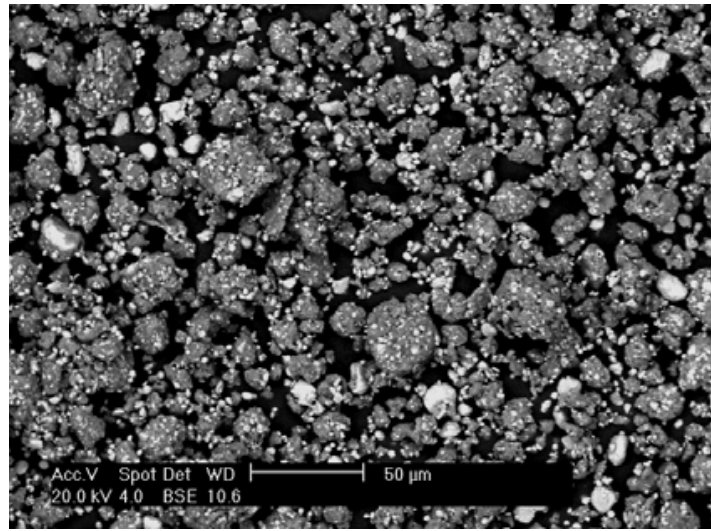

D - 120 minutos - MPA

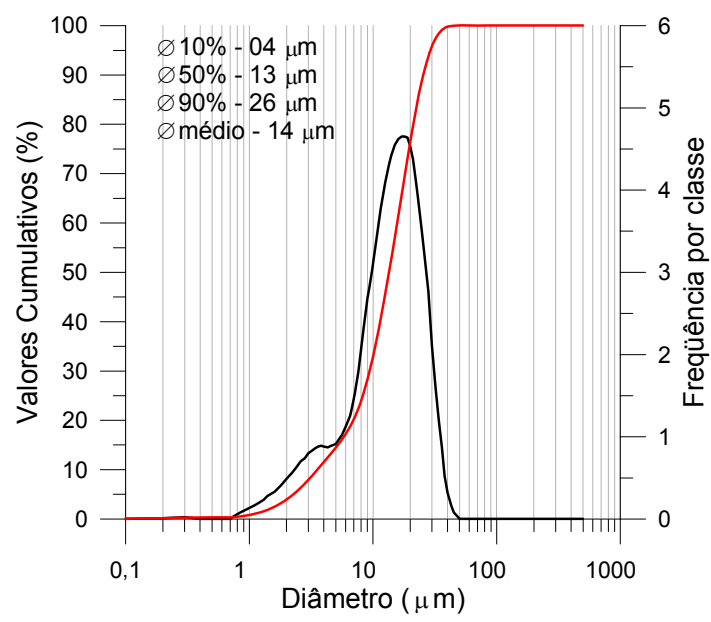

F - 120 minutos - MPA

FIGURA 22 - Micrografias de pó solto de misturas moídas a partir de pós como recebidos (MCR) e pré-ativados (MPA), após 20 e 120 minutos de moagem, e distribuições de tamanho de partícula das misturas com 120 minutos de moagem. Microscopia eletrônica de varredura com imagem de elétrons retroespalhados. 


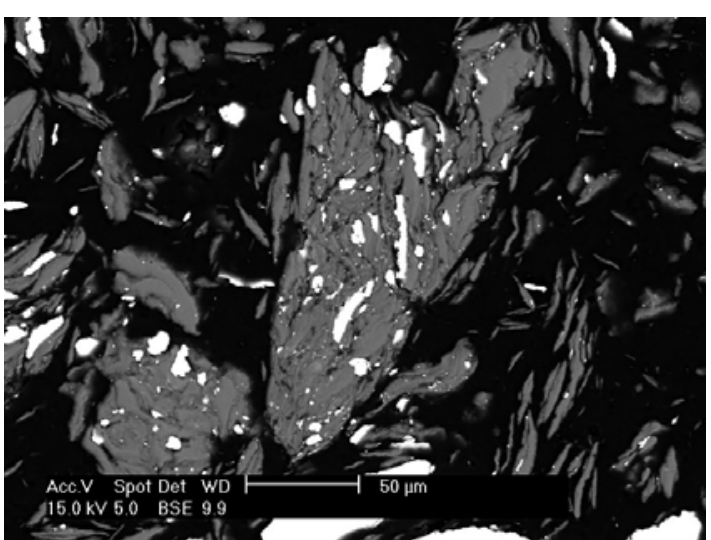

A - 20 minutos - MCR

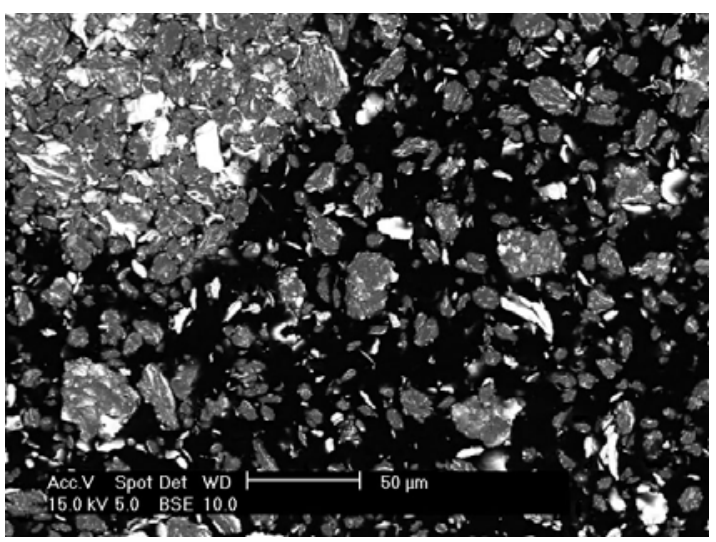

C - 120 minutos - MCR

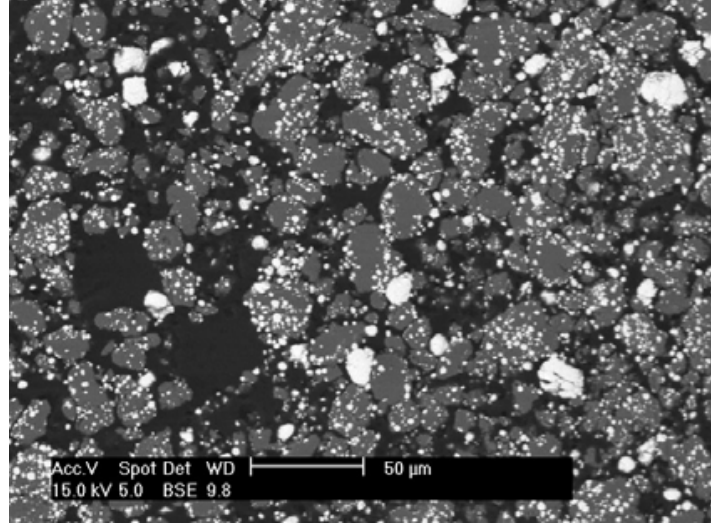

B - 20 minutos - MPA

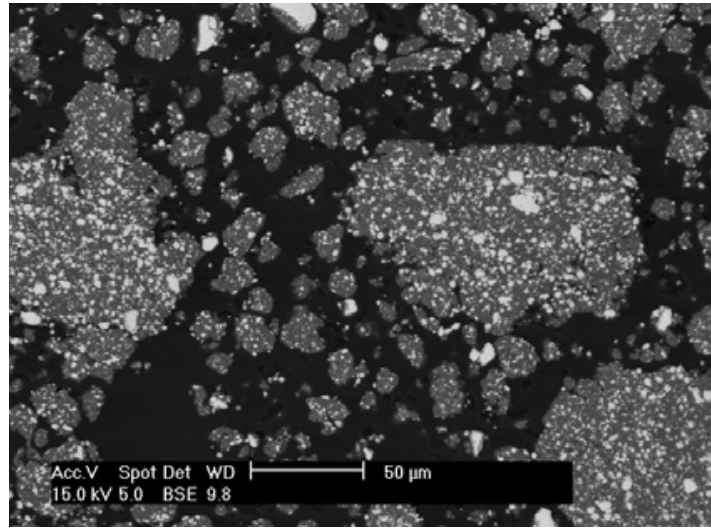

D - 120 minutos - MPA

FIGURA 23 - Micrografias de pó embutido de misturas moídas a partir de pós como recebidos (MCR) e pré-ativados (MPA), após 20 e 120 minutos de moagem. Microscopia eletrônica de varredura com imagem de elétrons retroespalhados.

partículas de nióbio dentro dos agregados, observada entre 20 e 120 minutos de moagem (FIG.23B e D), sugere que o mecanismo de formação dos agregados seja o de incrustação das partículas finas de nióbio nas partículas de alumínio. Esse mecanismo produziu uma distribuição de nióbio nos agregados muito diferente da distribuição lamelar.

Na FIG.24 estão apresentadas duas micrografias de pó embutido relativas à mistura moída durante 120 minutos a partir de reagentes pré-ativados e recozidos (MPA-R). A micrografia $B$ mostra uma estrutura com aspecto mais lamelar decorrente da diminuição da resistência das partículas provocada pelo tratamento de recozimento, permitindo que as partículas de nióbio se deformassem durante a moagem. Entretanto, o tamanho reduzido das partículas de nióbio formou plaquetas menores, originando agregados com dispersão de nióbio mais homogênea e mais fina, em relação à mistura moída de reagentes como recebidos (MCR). 


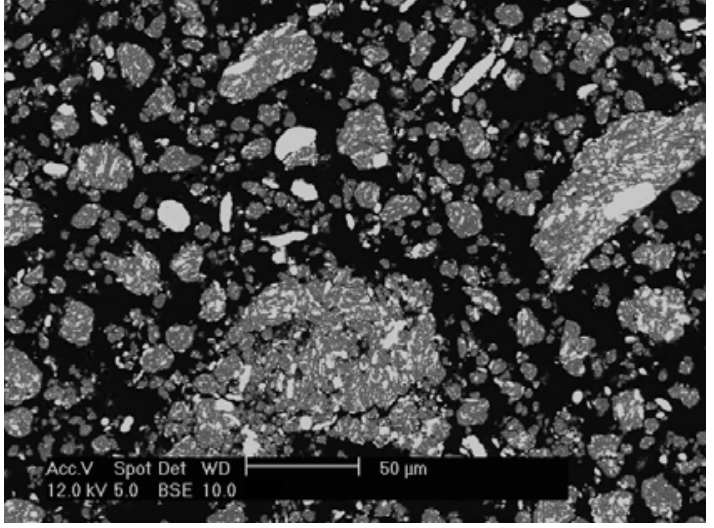

A

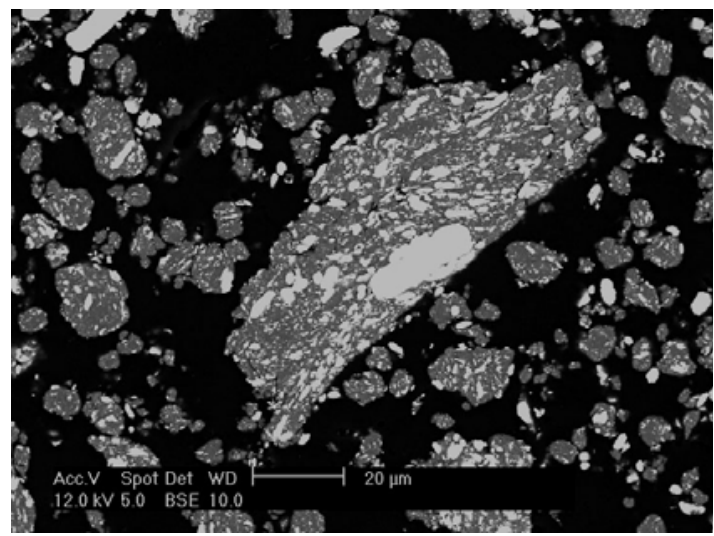

B

FIGURA 24 - Micrografias de pó embutido de misturas de reagentes pré-ativados e recozidos (MPA-R), após 120 minutos de moagem. Microscopia eletrônica de varredura com imagem de elétrons retroespalhados.

\section{Misturas MPA-A e MPA-N}

As micrografias de pó solto e embutido das misturas do tipo MPA-A estão apresentadas nas FIG.25 e 26. Esse tipo de mistura utiliza pó de alumínio préativado e nióbio como recebido. A utilização de alumínio no estado encruado não impediu a formação de partículas e agregados achatados para o caso da moagem de 20 minutos. Entretanto, a análise granulométrica mostra que, apesar da mudança de forma, o tamanho médio das partículas e agregados ainda permanece abaixo de $20 \mu \mathrm{m}$.

A comparação das micrografias da FIG.25 e 26 com as micrografias da FIG.22A e 23A, relativas às misturas sem pré-ativação, sugere um tamanho médio de partícula menor no caso de moagem de 20 minutos com alumínio préativado (MPA-A). Essa comparação visual é importante, pois a análise granulométrica de partículas achatadas geralmente fornece valores incorretos.

A moagem com 120 minutos produziu agregados com microestrutura lamelar muito semelhante à das misturas sem pré-ativação. A quantidade total de ACP na mistura MPA-A é de 1,9\% em peso, sendo 1,6\% já adicionados na préativação do alumínio e 0,3\% adicionado para a moagem da mistura. O tamanho médio das partículas e agregados nas misturas sem pré-ativação e com 1,9\% de ACP (FIG.22E) foi menor que a apresentada pela mistura utilizando somente alumínio pré-ativado (FIG.25F), indicando que o ACP já adicionado no alumínio pré-ativado não produz o mesmo efeito do ACP adicionado diretamente à mistura. 


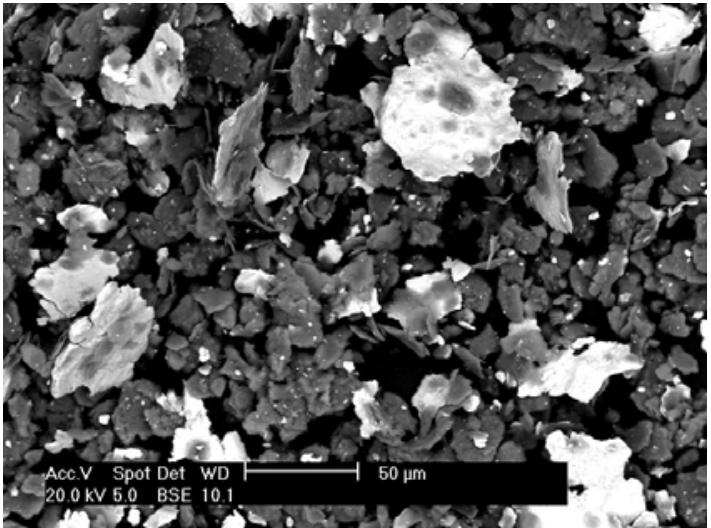

A - 20 minutos

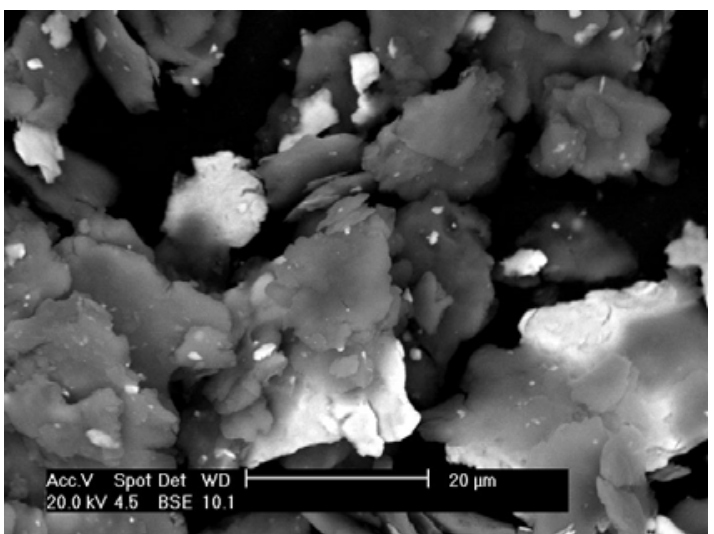

C - 20 minutos

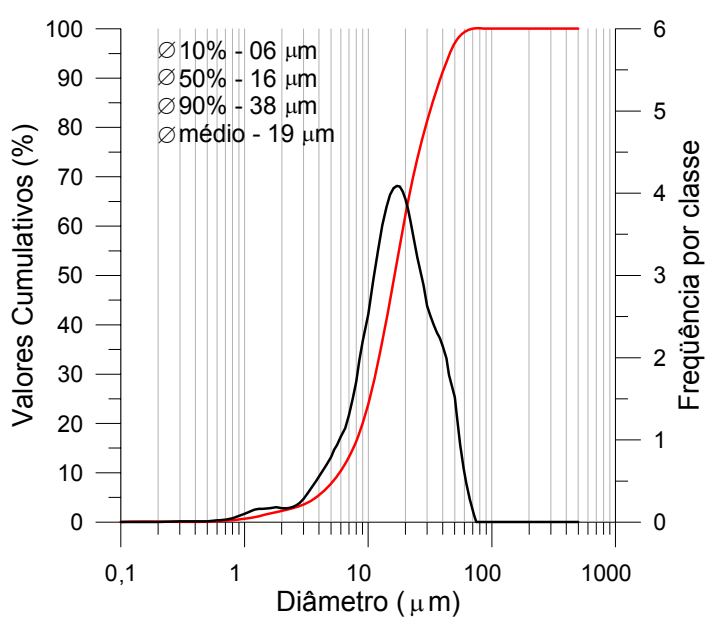

E - 20 minutos

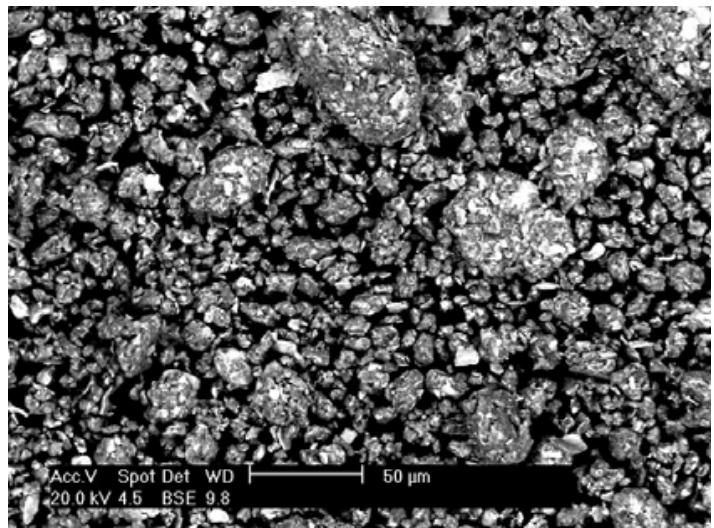

B - 120 minutos

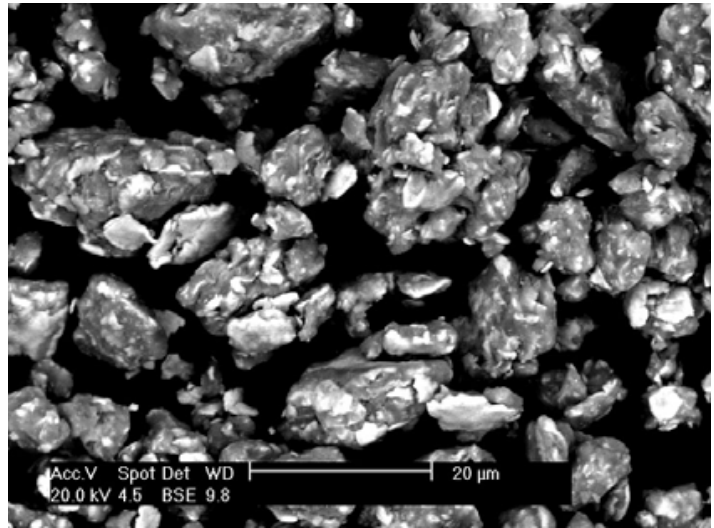

D - 120 minutos

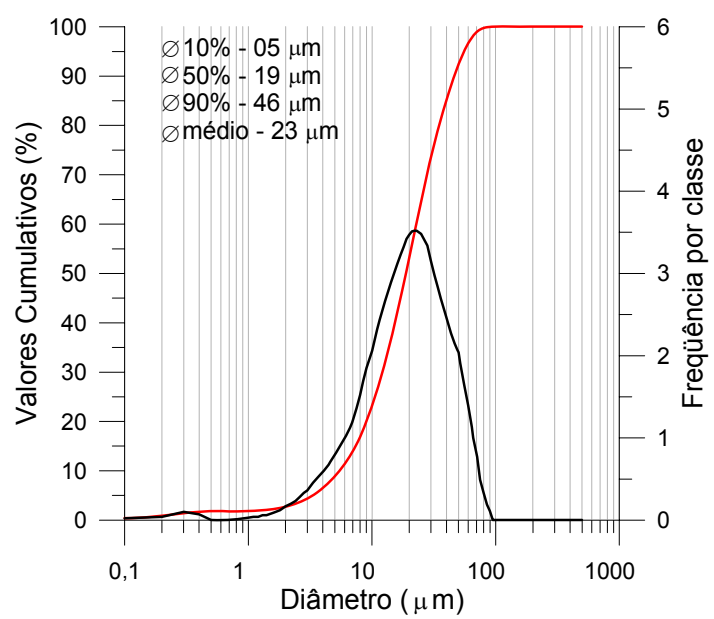

F - 120 minutos

FIGURA 25 - Micrografias de pó solto de misturas preparadas a partir de alumínio pré-ativado e nióbio como recebido (MPA-A), após 20 e 120 minutos de moagem, e distribuições de tamanho de partícula das misturas com 120 minutos de moagem. Microscopia eletrônica de varredura com imagem de elétrons retroespalhados. 


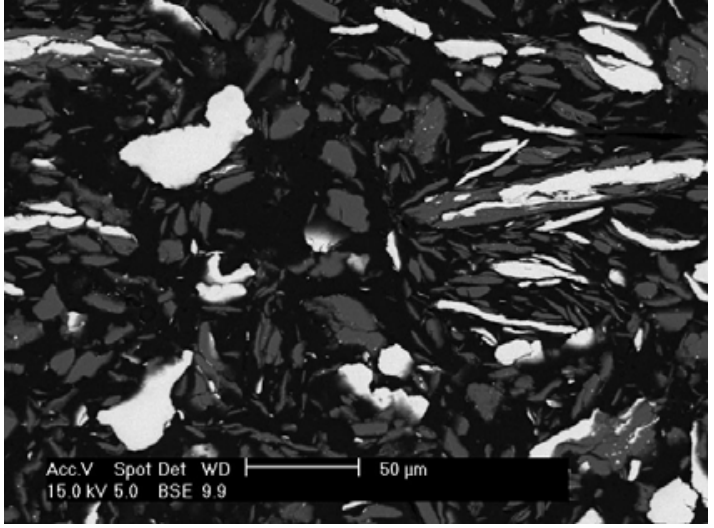

A - 20 minutos

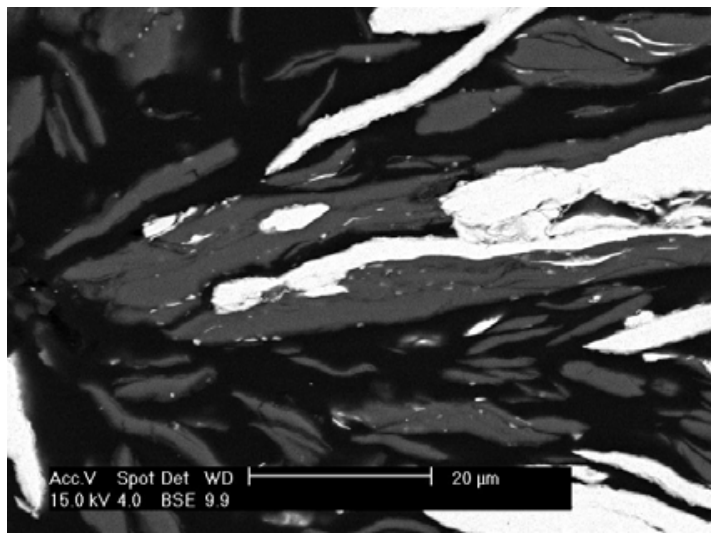

C - 20 minutos

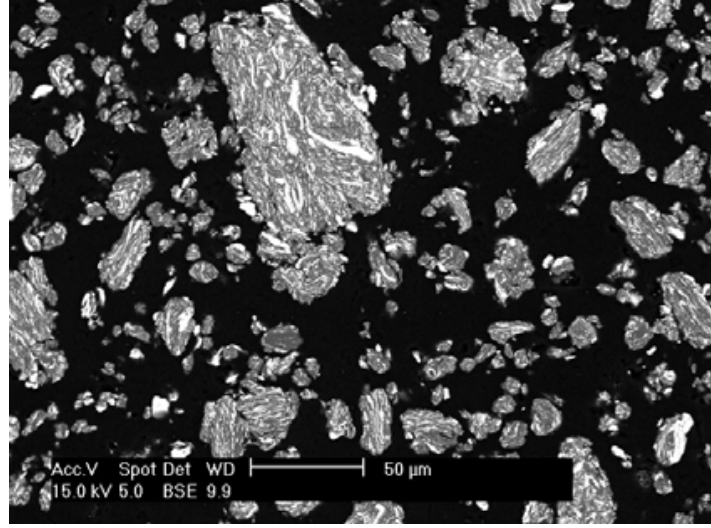

B -120 minutos

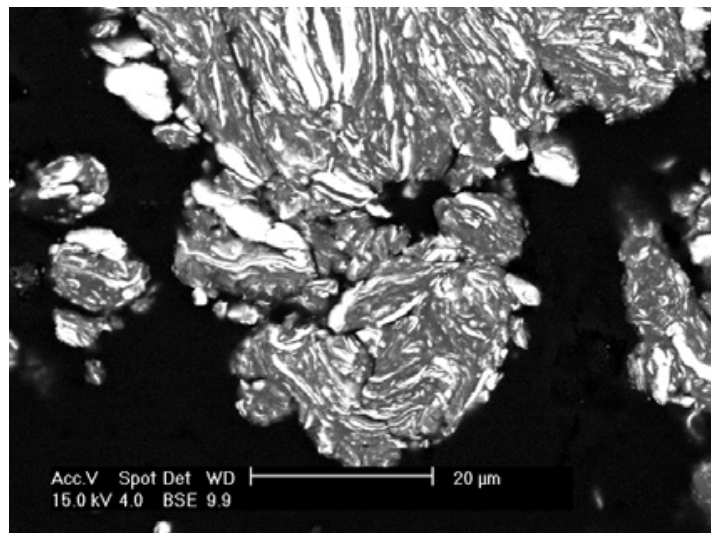

D - 120 minutos

FIGURA 26 - Micrografias de pó embutido de misturas preparadas a partir de alumínio pré-ativado e nióbio como recebido (MPA-A) após 20 e 120 minutos de moagem. Microscopia eletrônica de varredura com imagem de elétrons retroespalhados.

A semelhança de forma e microestrutura das partículas e agregados entre as misturas MCR (FIG.23A e C) e MPA-A (FIG.26A e B) em contraposição à mistura MPA (FIG.23B e D) revela a preponderância do estado encruado do nióbio na formação da microestrutura dos agregados.

As micrografias de pó solto e embutido das misturas do tipo MPA-N (alumínio como recebido e nióbio pré-ativado) estão apresentadas nas FIG.27 e 28. Esse tipo de mistura utiliza pó de nióbio pré-ativado e alumínio como recebido e uma quantidade complementar de ACP de 1,6\% em peso. Na moagem com 20 minutos também ocorreu o achatamento das partículas de alumínio, porém, a quantidade maior de ACP complementar e a presença de partículas finas e encruadas de alumínio, produziram um tamanho médio de partícula e agregado, menor que a constatada na mistura do tipo MPA-A. A mistura com 120 minutos de moagem apresentou microestrutura e distribuição granulométrica muito semelhantes às da mistura do tipo MPA. 


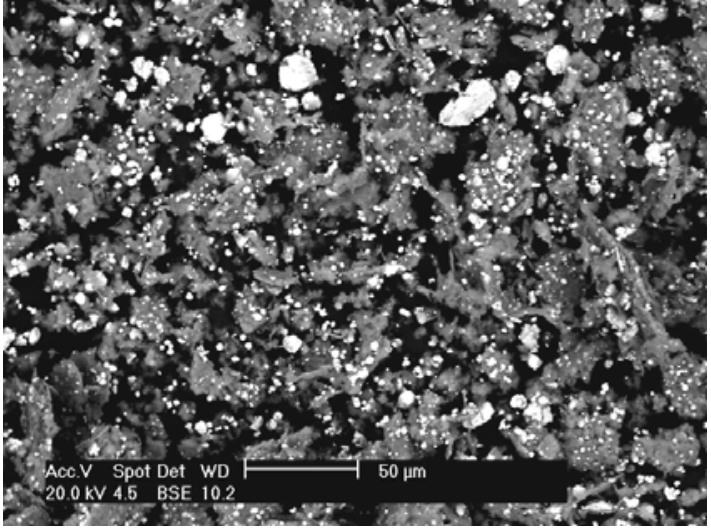

A - 20 minutos

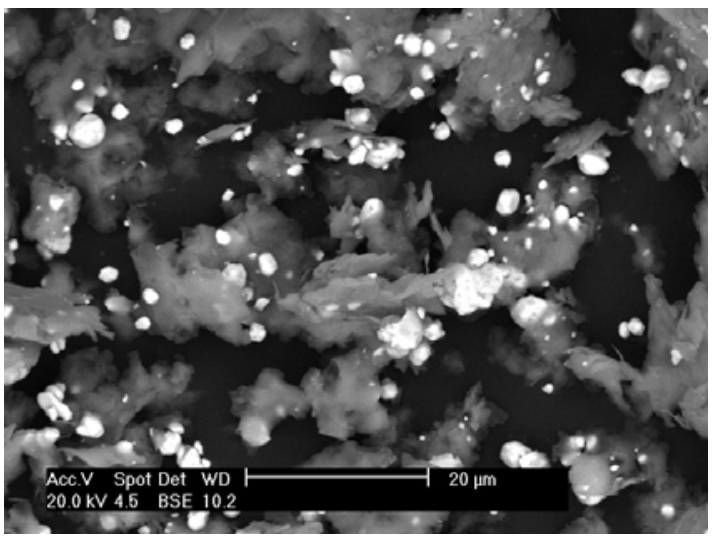

C - 20 minutos

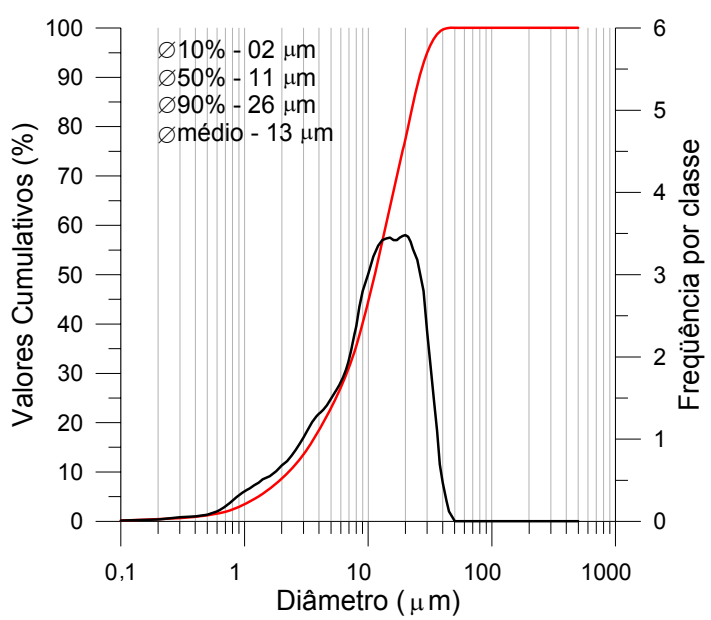

E - 20 minutos

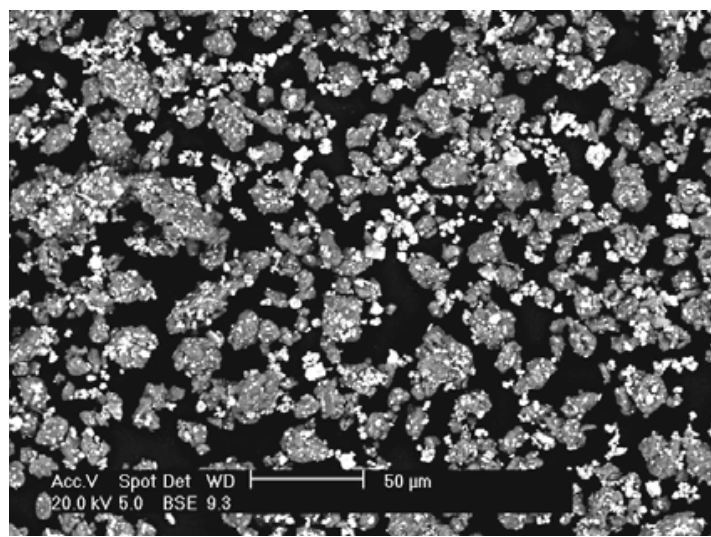

B - 120 minutos

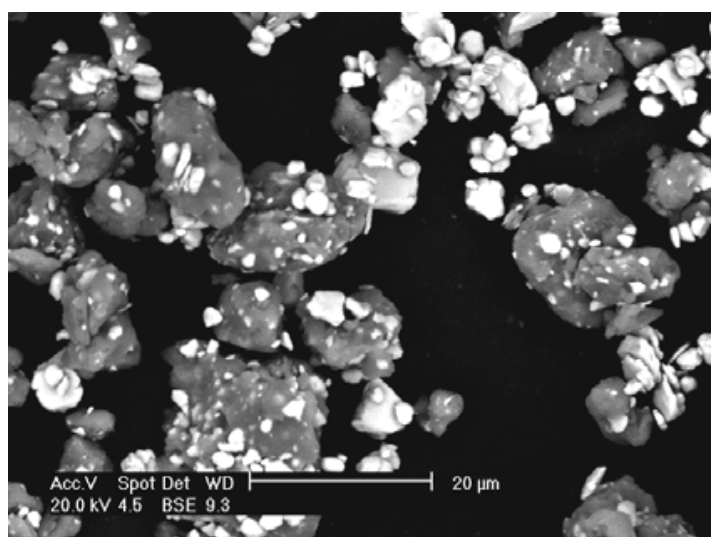

D - 120 minutos

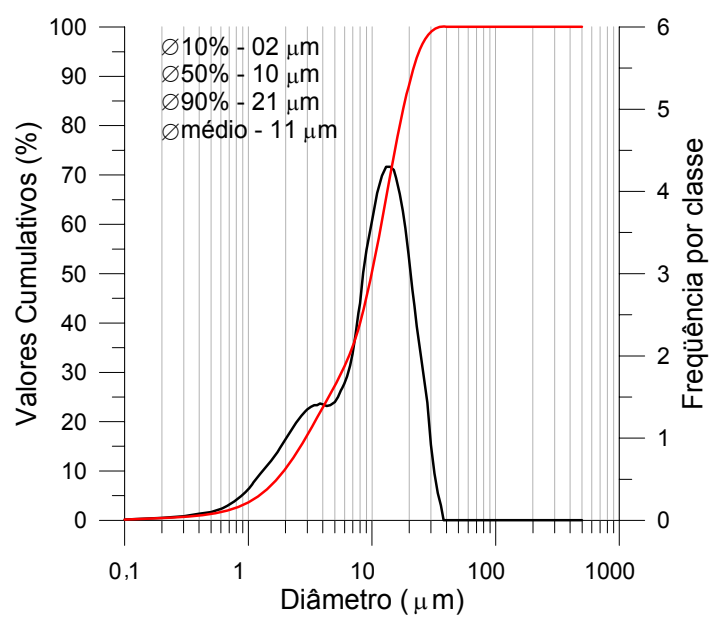

F - 120 minutos

FIGURA 27 - Micrografias de pó solto de misturas preparadas a partir de alumínio como recebido e nióbio pré-ativado (MPA-N), após 20 e 120 minutos de moagem, e distribuições de tamanho de partícula das misturas com 120 minutos de moagem. Microscopia eletrônica de varredura com imagem de elétrons retroespalhados. 


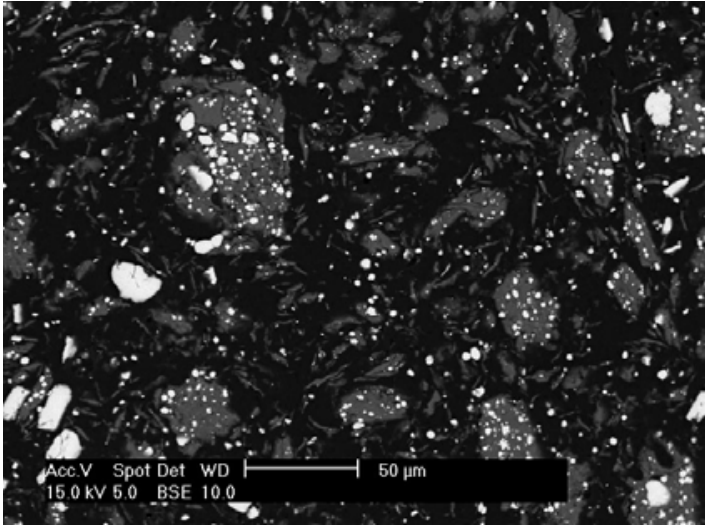

A - 20 minutos

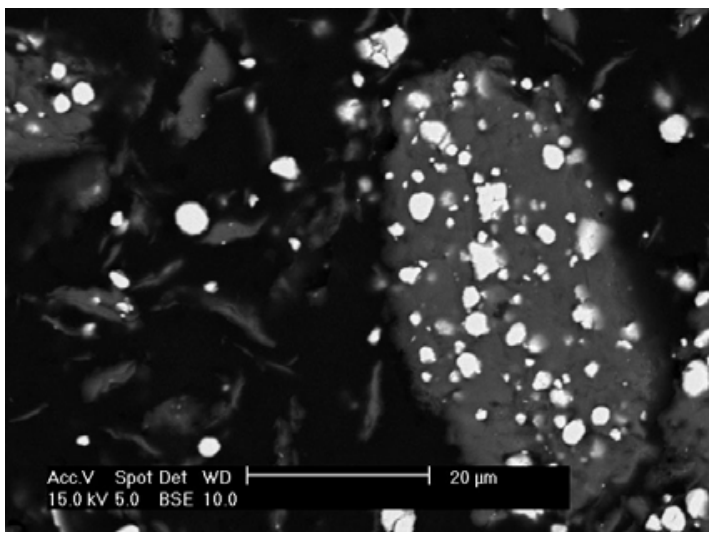

C - 20 minutos

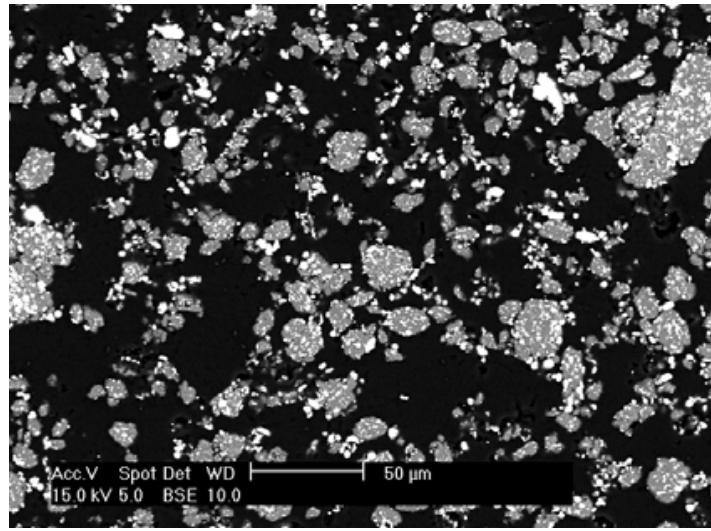

B - 120 minutos

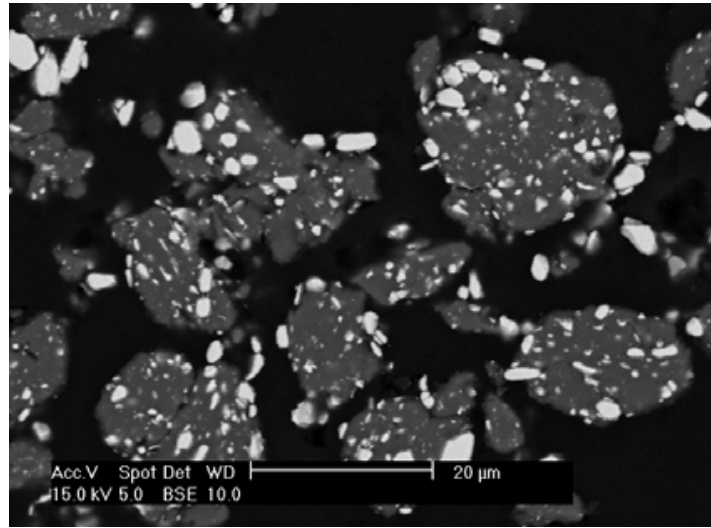

D - 120 minutos

FIGURA 28 - Micrografias de pó embutido de misturas preparadas a partir de alumínio como recebido e nióbio pré-ativado (MPA-N) após 20 e 120 minutos de moagem. Microscopia eletrônica de varredura com imagem de elétrons retroespalhados.

\subsubsection{DIFRAÇÃO DE RAIOS X}

\section{Misturas MCR e MPA}

Os difratogramas de raios $X$ referentes às misturas moídas a partir de pós como recebidos (MCR) com 20 e 120 minutos de moagem estão apresentados na FIG.29. Os resultados obtidos no refinamento de parâmetros de rede, tamanho de cristalito e microdeformação, utilizando o método de Rietveld, estão nas TAB.9, 10 e 11.

Para melhorar a qualidade de ajuste do refinamento do difratograma referente à mistura com 120 minutos de moagem, foi necessário introduzir uma nova fase. A variação de forma da base dos picos sobrepostos 111(Al) e 110(Nb) e, em menor grau, nos demais picos do nióbio, sugeriu que estaria ocorrendo uma convolução de picos com uma nova fase. Com base no histórico de hidretação do 
nióbio durante a moagem com alta energia na presença de $\mathrm{ACP}$, optou-se por inserir a fase $\mathrm{Nb}(\mathrm{H})$ nos refinamentos.

Algumas restrições foram usadas durante o refinamento com o intuito de minimizar a correlação dos parâmetros refinados. A restrição principal foi em relação à distribuição de tamanho de cristalito da fase $\mathrm{Nb}(\mathrm{H})$, inicialmente considerada sempre idêntica à calculada para o nióbio. Após o refino dos parâmetros relativos ao nióbio e ao alumínio, estes foram fixados para o refino da fase $\mathrm{Nb}(\mathrm{H})$. Essa estratégia permitiu refinar simultaneamente o parâmetro de rede da fase $\mathrm{Nb}(\mathrm{H})$ e sua fração volumétrica. Os resultados obtidos estão apresentados na TAB.9.

A inserção da fase $\mathrm{Nb}(\mathrm{H})$ alterou significativamente o resultado dos refinamentos iniciais. Apesar da boa qualidade de ajuste obtida, a inserção da nova fase aumentou a incerteza dos resultados, em razão da alta sobreposição de picos e da baixa fração volumétrica dessa nova fase. O alargamento dos picos de difração é modelado pela função pseudo-voigt, que consiste na convolução das funções gaussiana e lorentziana. No modelamento utilizado no programa MAUD®, essas funções representam os efeitos da microdeformação e tamanho de cristalito, respectivamente. A sobreposição dificulta o ajuste do perfil dos picos, o que afeta diretamente a proporção entre as funções gaussiana e lorentziana. No caso da fase $\mathrm{Nb}(\mathrm{H})$, a sobreposição pode provocar uma redução da fração da função lorentziana dos picos de nióbio, devido à fase $\mathrm{Nb}(\mathrm{H})$ apresentar picos bem alargados. Essa situação pode fornecer valores de tamanho de cristalito e de microdeformação maiores para o nióbio. Quanto aos valores de microdeformação de tamanho de cristalito da fase $\mathrm{Nb}(\mathrm{H})$, a baixa fração volumétrica confere aos resultados, apresentados na TAB.9, apenas um caráter qualitativo.

TABELA 9 - Tamanho de cristalito e microdeformação da fase $\mathrm{Nb}(\mathrm{H})$ na mistura tipo MCR após moagem de 120 minutos.

\begin{tabular}{|c|c|c|c|c|c|}
\hline $\begin{array}{c}\text { Tamanho } \\
\text { de cristalito } \\
(\mathrm{nm})\end{array}$ & $\begin{array}{c}\text { Micro } \\
\text { deformação } \\
(\%)\end{array}$ & $\begin{array}{c}\text { Parâmetro } \\
\text { de rede } \\
(\AA)\end{array}$ & $\begin{array}{c}\text { Fração } \\
\text { Vol. } \\
(\%)\end{array}$ & $\begin{array}{c}\mathrm{R}_{\mathrm{wp}} \\
(\%)\end{array}$ & $\begin{array}{c}\text { Qualidade } \\
\text { de ajuste }\end{array}$ \\
\hline 17 & 1,942 & $3,3636 \pm 0,0007$ & $4 \pm 1$ & 7,50 & 1,272 \\
\hline
\end{tabular}



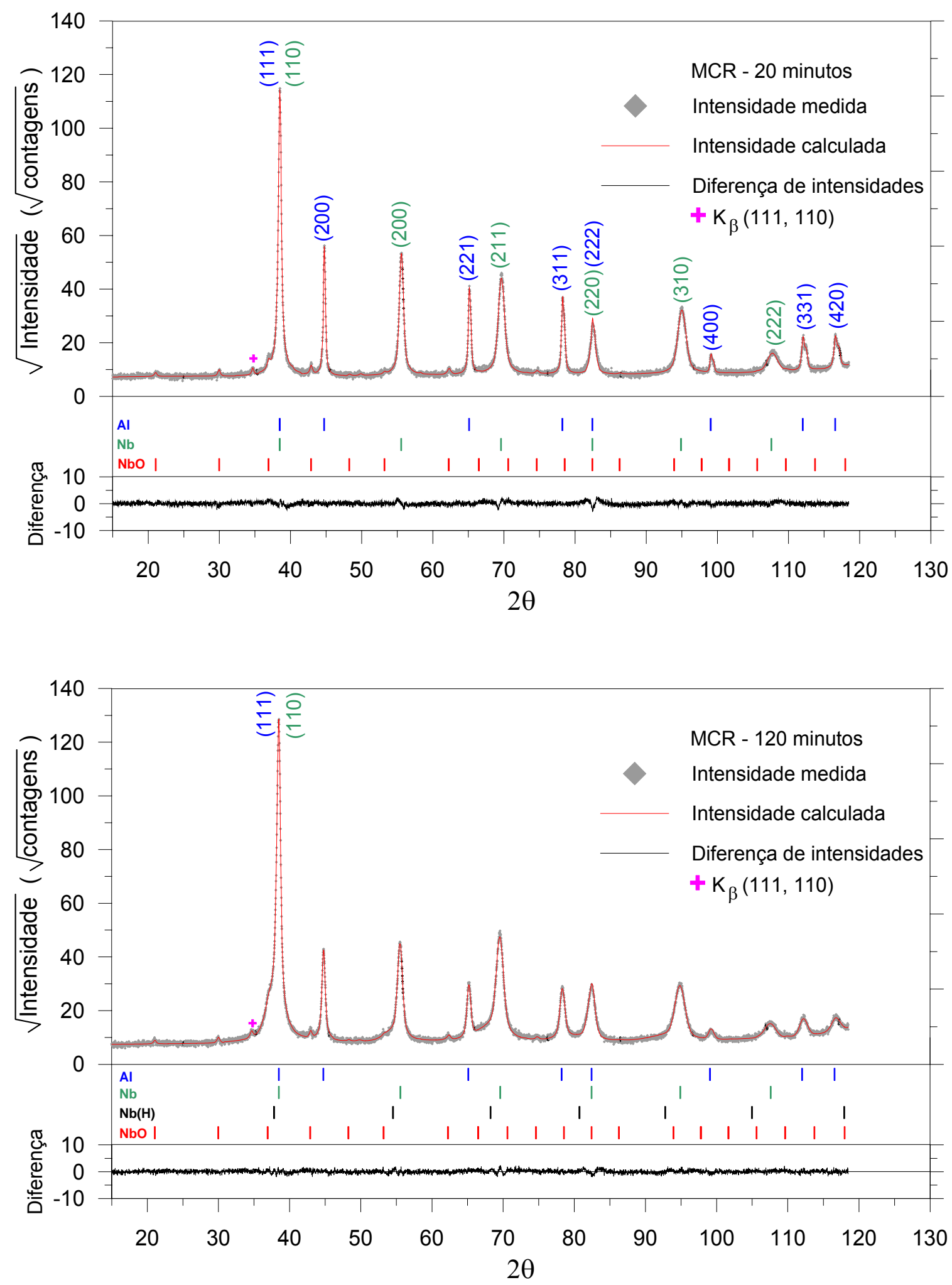

FIGURA 29 - Difratogramas das misturas preparadas a partir de reagentes como recebidos (MCR) após 20 e 120 minutos de moagem, analisados pelo método de Rietveld. 
TABELA 10 -Tamanho de cristalito, microdeformação e parâmetro de rede do alumínio em misturas de reagentes como recebidos (MCR), após moagem de 20 e 120 minutos.

\begin{tabular}{|c|c|c|c|c|}
\hline \multirow[t]{2}{*}{ Plano } & \multicolumn{2}{|c|}{ Alumínio - MCR - 20 minutos } & \multicolumn{2}{|c|}{ Alumínio - MCR - 120 minutos } \\
\hline & $\begin{array}{l}\text { Tamanho de } \\
\text { cristalito(nm) }\end{array}$ & $\begin{array}{c}\text { Microdeformação } \\
(\%)\end{array}$ & $\begin{array}{l}\text { Tamanho de } \\
\text { cristalito(nm) }\end{array}$ & $\begin{array}{c}\text { Microdeformação } \\
(\%)\end{array}$ \\
\hline 111 & 75,9 & 0,043 & 104,6 & 0,151 \\
\hline 200 & 95,6 & 0,054 & 32,6 & 0,149 \\
\hline 220 & 76,7 & 0,046 & 31,6 & 0,150 \\
\hline 311 & 75,2 & 0,049 & 23,6 & 0,150 \\
\hline 222 & 75,9 & 0,043 & 104,6 & 0,151 \\
\hline 400 & 95,6 & 0,054 & 32,6 & 0,149 \\
\hline 331 & 63,8 & 0,045 & 16,7 & 0,151 \\
\hline 420 & 63,2 & 0,049 & 12,6 & 0,150 \\
\hline Média & 78 & 0,048 & 45 & 0,150 \\
\hline $\begin{array}{l}\text { Desvio } \\
\text { Padrão }\end{array}$ & 12 & 0,005 & 38 & 0,001 \\
\hline $\begin{array}{l}\text { Parâmetro } \\
\text { de rede }(\AA)\end{array}$ & \multicolumn{2}{|c|}{$4,04941 \pm 0,00004$} & \multicolumn{2}{|c|}{$4,0486 \pm 0,0001$} \\
\hline $\mathrm{R}_{\mathrm{wp}}(\%)$ & \multicolumn{2}{|r|}{8,52} & \multicolumn{2}{|r|}{7,50} \\
\hline $\begin{array}{l}\text { Qualidade } \\
\text { de ajuste }\end{array}$ & \multicolumn{2}{|c|}{1,257} & \multicolumn{2}{|c|}{1,272} \\
\hline
\end{tabular}

TABELA 11 -Tamanho de cristalito, microdeformação e parâmetro de rede do nióbio em misturas de reagentes como recebidos (MCR) após moagem de 20 e 120 minutos.

\begin{tabular}{|c|c|c|c|c|}
\hline \multirow[t]{2}{*}{ Plano } & \multicolumn{2}{|c|}{ Nióbio - MCR - 20 minutos } & \multicolumn{2}{|c|}{ Nióbio - MCR - 120 minutos } \\
\hline & $\begin{array}{l}\text { Tamanho de } \\
\text { cristalito(nm) }\end{array}$ & $\begin{array}{c}\text { Microdeformação } \\
(\%)\end{array}$ & $\begin{array}{l}\text { Tamanho de } \\
\text { cristalito(nm) }\end{array}$ & $\begin{array}{c}\text { Microdeformação } \\
(\%)\end{array}$ \\
\hline 110 & 37,5 & 0,27 & 32,8 & 0,353 \\
\hline 200 & 33,4 & 0,21 & 38,8 & 0,351 \\
\hline 211 & 21,8 & 0,27 & 20,7 & 0,353 \\
\hline 220 & 37,5 & 0,27 & 32,8 & 0,353 \\
\hline 310 & 19,7 & 0,23 & 19,0 & 0,352 \\
\hline 222 & 18,6 & 0,28 & 13,5 & 0,353 \\
\hline Média & 28 & 0,25 & 26 & 0,352 \\
\hline $\begin{array}{l}\text { Desvio } \\
\text { Padrão }\end{array}$ & 9 & 0,03 & 10 & 0,001 \\
\hline $\begin{array}{l}\text { Parâmetro } \\
\text { de rede }(\AA)\end{array}$ & \multicolumn{2}{|c|}{$3,30706 \pm 0,00005$} & \multicolumn{2}{|c|}{$3,3116 \pm 0,0001$} \\
\hline $\mathrm{R}_{\mathrm{wp}}(\%)$ & \multicolumn{2}{|r|}{8,52} & \multicolumn{2}{|r|}{7,50} \\
\hline $\begin{array}{l}\text { Qualidade } \\
\text { de ajuste }\end{array}$ & \multicolumn{2}{|c|}{1,257} & \multicolumn{2}{|c|}{1,272} \\
\hline
\end{tabular}


Os valores apresentados nas TAB.10 e 11 mostram que tamanho de cristalito decresce e a microdeformação cresce com o tempo de moagem, tanto para o nióbio quanto para o alumínio. Esse comportamento é compatível com o aumento da densidade de defeitos cristalinos que são as principais fontes de alargamento dos picos de difração. Observa-se também que os valores de tamanho de cristalito e microdeformação do alumínio após 120 minutos de moagem ( $45 \mathrm{~nm}$ e $0,150 \%$ ) são muito semelhantes aos valores obtidos na préativação (36 nm e 0,135\%). Essa constatação mostra que o alumínio atinge rapidamente um certo nível de densidade de defeitos cristalinos que se mantém constante com a extensão do tempo de moagem. No caso do nióbio, a variação principal entre 20 e 120 minutos de moagem foi a microdeformação. Entretanto, a condição atingida após 120 minutos de moagem ( $26 \mathrm{~nm}$ e $0,352 \%)$ é bem diferente da obtida pela pré-ativação $(6,6 \mathrm{~nm}$ e $0,740 \%)$.

A mistura MPA com 120 minutos de moagem foi caracterizada por difração de raios-X e o difratograma está apresentado na FIG.30. Os resultados obtidos de tamanho de cristalito, microdeformação e parâmetro de rede estão apresentados nas TAB.12 e 13, em conjunto com os dados da mistura MCR com 120 minutos de moagem para facilitar a comparação de resultados.

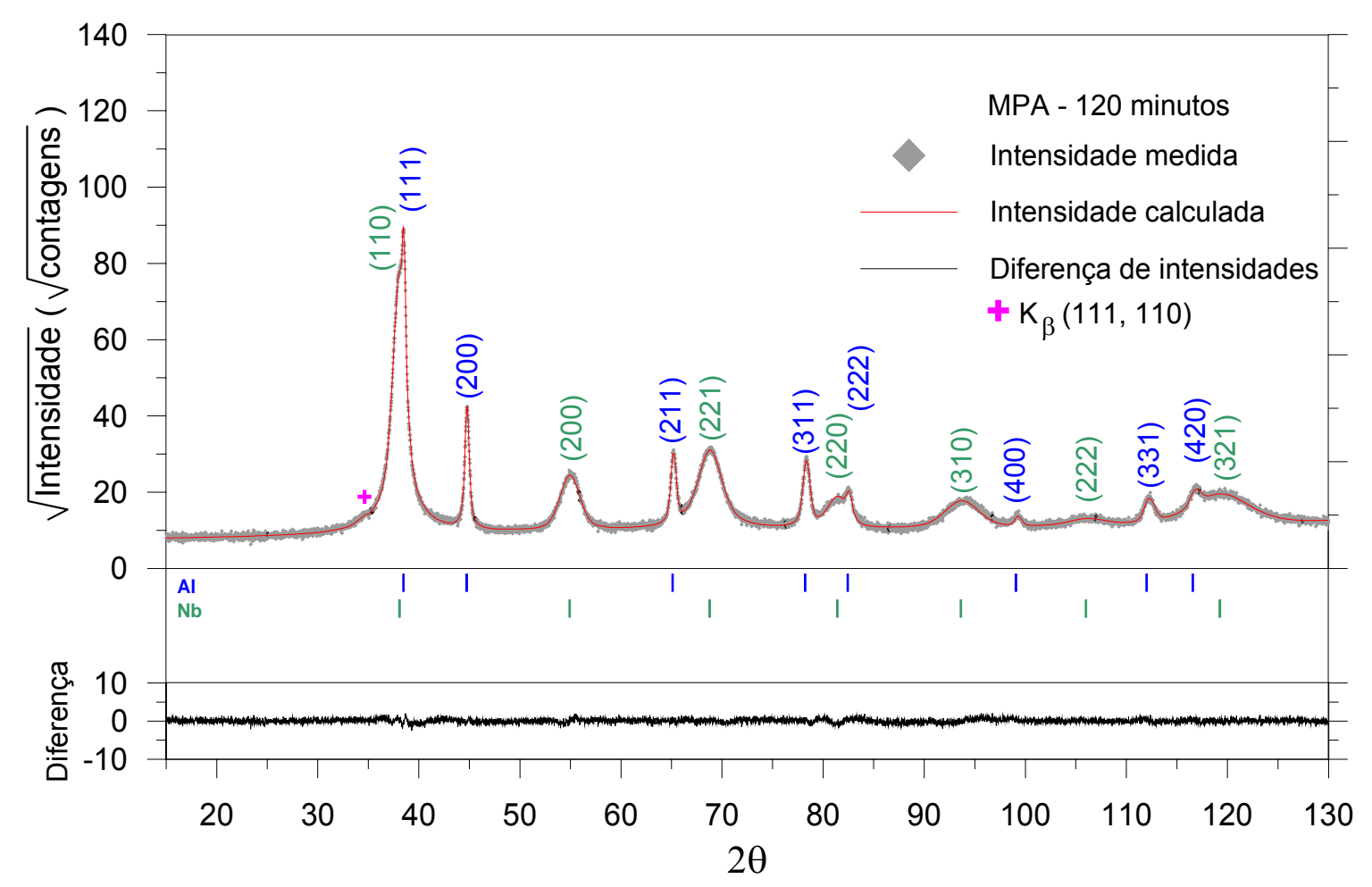

FIGURA 30 - Difratograma da mistura preparada a partir de pós pré-ativados (MPA) após 120 minutos de moagem, analisada pelo método de Rietveld. 
TABELA 12 -Tamanho de cristalito, microdeformação e parâmetro de rede do alumínio em misturas de reagentes como recebidos (MCR) e de reagentes pré-ativados (MPA), após 120 minutos de moagem.

\begin{tabular}{|c|c|c|c|c|}
\hline \multirow[t]{2}{*}{ Plano } & \multicolumn{2}{|c|}{ Alumínio - MCR - 120 minutos } & \multicolumn{2}{|c|}{ Alumínio - MPA - 120 minutos } \\
\hline & $\begin{array}{l}\text { Tamanho de } \\
\text { cristalito(nm) }\end{array}$ & $\begin{array}{c}\text { Microdeformação } \\
(\%)\end{array}$ & $\begin{array}{l}\text { Tamanho de } \\
\text { cristalito(nm) }\end{array}$ & \begin{tabular}{|c} 
Microdeformação \\
$(\%)$
\end{tabular} \\
\hline 111 & 104,6 & 0,151 & 52,5 & 0,163 \\
\hline 200 & 32,6 & 0,149 & 33,9 & 0,135 \\
\hline 220 & 31,6 & 0,150 & 28,6 & 0,156 \\
\hline 311 & 23,6 & 0,150 & 22,2 & 0,149 \\
\hline 222 & 104,6 & 0,151 & 52,5 & 0,163 \\
\hline 400 & 32,6 & 0,149 & 33,9 & 0,135 \\
\hline 331 & 16,7 & 0,151 & 24,8 & 0,158 \\
\hline 420 & 12,6 & 0,150 & 24,8 & 0,149 \\
\hline Média & 45 & 0,150 & 34 & 0,151 \\
\hline $\begin{array}{l}\text { Desvio } \\
\text { Padrão }\end{array}$ & 38 & 0,001 & 12 & 0,011 \\
\hline $\begin{array}{l}\text { Parâmetro } \\
\text { de rede }(\AA)\end{array}$ & \multicolumn{2}{|c|}{$4,0486 \pm 0,0001$} & \multicolumn{2}{|c|}{$4,0460 \pm 0,0001$} \\
\hline $\mathrm{R}_{\mathrm{wp}}(\%)$ & \multicolumn{2}{|r|}{7,50} & \multicolumn{2}{|r|}{6,72} \\
\hline $\begin{array}{l}\text { Qualidade } \\
\text { de ajuste }\end{array}$ & \multicolumn{2}{|c|}{1,272} & \multicolumn{2}{|c|}{1,142} \\
\hline
\end{tabular}

TABELA 13 -Tamanho de cristalito, microdeformação e parâmetro de rede do nióbio em misturas de reagentes como recebidos (MCR) e de reagentes pré-ativados (MPA), após 120 minutos de moagem.

\begin{tabular}{|c|c|c|c|c|}
\hline \multirow{2}{*}{ Plano } & \multicolumn{2}{|c|}{ Nióbio - MCR - 120 minutos } & \multicolumn{2}{c|}{ Nióbio - MPA - 120 minutos } \\
\cline { 2 - 5 } & $\begin{array}{c}\text { Tamanho de } \\
\text { cristalito(nm) }\end{array}$ & $\begin{array}{c}\text { Microdeformação } \\
(\%)\end{array}$ & $\begin{array}{c}\text { Tamanho de } \\
\text { cristalito(nm) }\end{array}$ & $\begin{array}{c}\text { Microdeformação } \\
(\%)\end{array}$ \\
\hline 110 & 32,8 & 0,353 & 9,6 & 0,70 \\
\hline 200 & 38,8 & 0,351 & 7,9 & 0,98 \\
\hline 211 & 20,7 & 0,353 & 5,2 & 0,70 \\
\hline 220 & 32,8 & 0,353 & 9,6 & 0,70 \\
\hline 310 & 19,0 & 0,352 & 5,6 & 0,89 \\
\hline 222 & 13,5 & 0,353 & 3,3 & 0,58 \\
\hline Média & $\mathbf{2 6}$ & $\mathbf{0 , 3 5 2}$ & $\mathbf{6 , 3}$ & $\mathbf{0 , 7 5}$ \\
\hline $\begin{array}{c}\text { Desvio } \\
\text { Padrão }\end{array}$ & $\mathbf{1 0}$ & $\mathbf{0 , 0 0 1}$ & $\mathbf{2 , 8}$ & $\mathbf{0 , 1 4}$ \\
\hline $\begin{array}{c}\text { Parâmetro } \\
\text { de rede }(\AA)\end{array}$ & \multicolumn{2}{|c|}{$\mathbf{3 , 3 1 1 6} \mathbf{0 , 0 0 0 1}$} & $\mathbf{3 , 3 4 0 7} \pm \mathbf{0 , 0 0 0 1}$ \\
\hline$R_{\text {wp }}(\%)$ & \multicolumn{2}{|c|}{$\mathbf{7 , 5 0}$} & \multicolumn{2}{c|}{$\mathbf{6 , 7 2}$} \\
\hline
\end{tabular}


Os valores obtidos para tamanho de cristalito e microdeformação, referentes à mistura MPA, são muito semelhantes aos determinados nas análises dos difratogramas dos reagentes pré-ativados. Constataram-se ainda diferenças com relação aos valores de parâmetro de rede dos materiais pré-ativados. No caso do nióbio, observou-se um aumento de 0,35\% e no caso do alumínio uma redução de $0,08 \%$. A ocorrência de sobreposição dos picos mais intensos em misturas $\mathrm{Nb}-\mathrm{Al}$ associada à baixa intensidade dos picos mais alargados, diminui a precisão do refinamento, o que explicaria a variação observada nos parâmetros de rede. Portanto, é possível considerar que a moagem por 120 minutos da mistura pré-ativada não produziu mudanças significativas na densidade de defeitos cristalinos das partículas de nióbio e de alumínio.

A comparação das misturas MCR e MPA (TAB.12 e 13) mostra que o alumínio está em condições semelhantes quanto à densidade de defeitos cristalinos. A diferença principal entre as duas misturas está na condição microestrutural do nióbio.

\section{Misturas MPA-A e MPA-N}

A análise por difração de raios- $X$ foi realizada somente nas amostras com 120 minutos de moagem. Os difratogramas estão apresentados na FIG.31 e os resultados do refinamento pelo método de Rietveld estão dispostos nas TAB.14 e 15. O refinamento do difratograma referente à mistura MPA-A considerou a presença da fase $\mathrm{Nb}(\mathrm{H})$.

Os resultados obtidos para a mistura MPA-N são muito semelhantes aos obtidos no caso do nióbio pré-ativado (TAB.6 - p.69) e do alumínio como recebido após moagem de 120 minutos (TAB.10 - p.91). Já no caso da mistura MPA-A houve uma redução do tamanho de cristalito, tanto no caso do nióbio, quanto no caso do alumínio. Enquanto o alumínio somente pré-ativado apresentou um tamanho médio de cristalito de $36 \mathrm{~nm}$ (TAB.5 - p.65), o valor obtido após 120 minutos de moagem da mistura MPA-A foi de $25 \mathrm{~nm}$. O nióbio presente na mistura de reagentes como recebidos (MCR) apresentou um tamanho médio de cristalito de $26 \mathrm{~nm}$ após 120 minutos de moagem (TAB.11 - p.91) enquanto que na mistura MPA-A esse valor foi de $17 \mathrm{~nm}$ (TAB.15). 

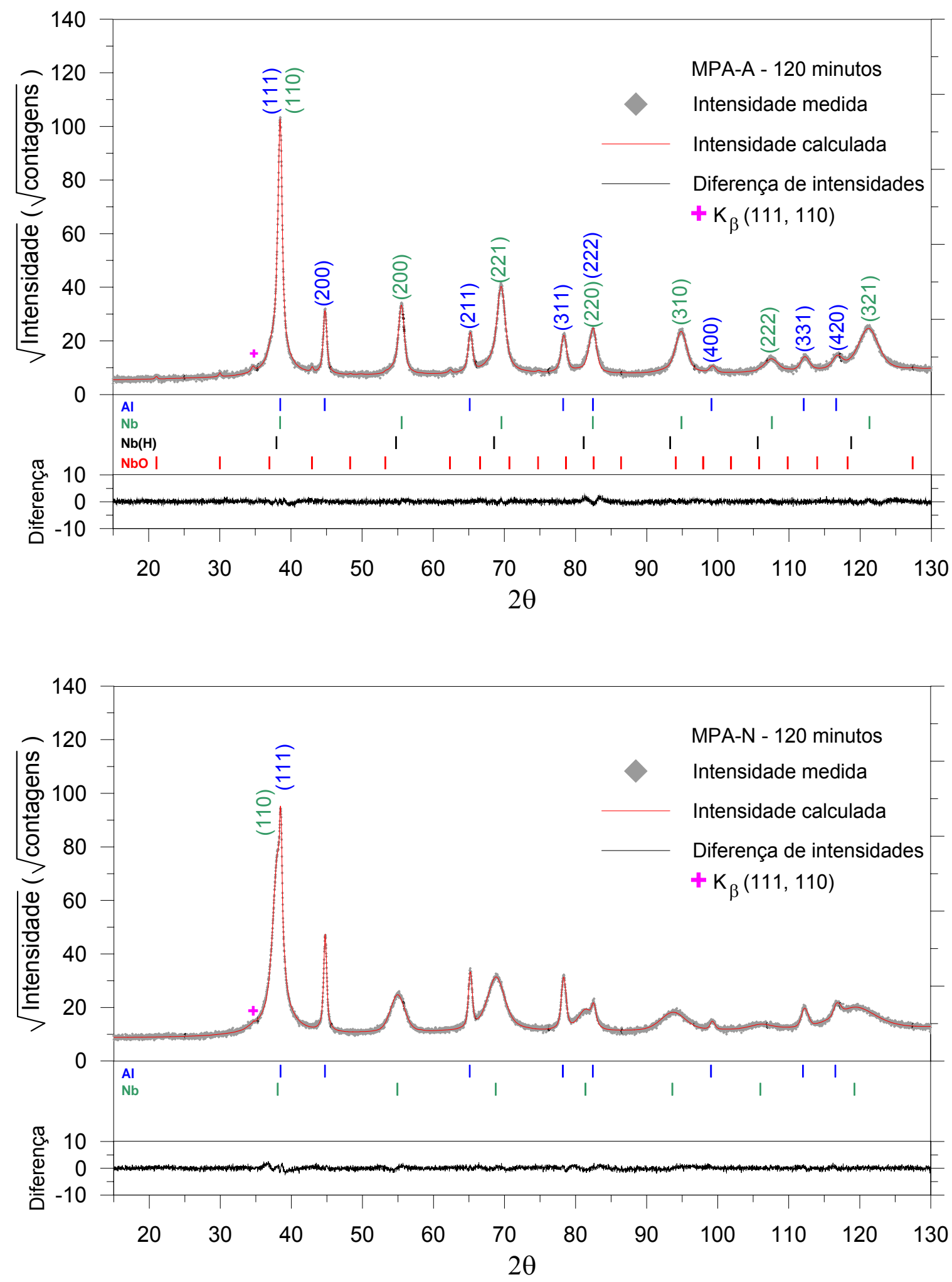

FIGURA 31 - Difratogramas das misturas moídas a partir de alumínio pré-ativado e nióbio como recebido (MPA-A) e de alumínio como recebido e nióbio pré-ativado (MPA-N), após 120 minutos de moagem, analisados pelo método de Rietveld. 
TABELA 14 -Tamanho de cristalito, microdeformação e parâmetro de rede do alumínio em misturas tipo MPA-A e MPA-N, após 120 minutos de moagem.

\begin{tabular}{|c|c|c|c|c|}
\hline \multirow[t]{2}{*}{ Plano } & \multicolumn{2}{|c|}{ Alumínio - MPA-A - 120 minutos } & \multicolumn{2}{|c|}{ Alumínio - MPA-N - 120 minutos } \\
\hline & $\begin{array}{l}\text { Tamanho de } \\
\text { cristalito(nm) }\end{array}$ & $\begin{array}{c}\text { Microdeformação } \\
(\%)\end{array}$ & $\begin{array}{l}\text { Tamanho de } \\
\text { cristalito }(\mathrm{nm})\end{array}$ & $\begin{array}{c}\text { Microdeformação } \\
(\%)\end{array}$ \\
\hline 111 & 35,9 & 0,109 & 55,4 & 0,171 \\
\hline 200 & 29,6 & 0,189 & 33,3 & 0,109 \\
\hline 220 & 21,2 & 0,134 & 32,7 & 0,157 \\
\hline 311 & 19,2 & 0,160 & 24,3 & 0,141 \\
\hline 222 & 35,9 & 0,109 & 55,4 & 0,171 \\
\hline 400 & 29,6 & 0,189 & 33,3 & 0,109 \\
\hline 331 & 12,8 & 0,127 & 37,7 & 0,161 \\
\hline 420 & 13,5 & 0,156 & 35,5 & 0,142 \\
\hline Média & 25 & 0,147 & 39 & 0,145 \\
\hline $\begin{array}{l}\text { Desvio } \\
\text { Padrão }\end{array}$ & 9 & 0,032 & 11 & 0,025 \\
\hline $\begin{array}{l}\text { Parâmetro } \\
\text { de rede }(\AA)\end{array}$ & \multicolumn{2}{|c|}{$4,0483 \pm 0,0001$} & \multicolumn{2}{|c|}{$4,0464 \pm 0,0001$} \\
\hline $\mathrm{R}_{\mathrm{wp}}(\%)$ & \multicolumn{2}{|r|}{7,93} & \multicolumn{2}{|r|}{6,75} \\
\hline $\begin{array}{l}\text { Qualidade } \\
\text { de ajuste }\end{array}$ & \multicolumn{2}{|c|}{1,148} & \multicolumn{2}{|c|}{1,197} \\
\hline
\end{tabular}

TABELA 15 -Tamanho de cristalito, microdeformação e parâmetro de rede do nióbio em misturas tipo MPA-A e MPA-N, após 120 minutos de moagem.

\begin{tabular}{|c|c|c|c|c|}
\hline \multirow[t]{2}{*}{ Plano } & \multicolumn{2}{|c|}{ Nióbio - MPA-A - 120 minutos } & \multicolumn{2}{|c|}{ Nióbio - MPA-N - 120 minutos } \\
\hline & $\begin{array}{l}\text { Tamanho de } \\
\text { cristalito(nm) }\end{array}$ & $\begin{array}{c}\text { Microdeformação } \\
(\%)\end{array}$ & $\begin{array}{l}\text { Tamanho de } \\
\text { cristalito(nm) }\end{array}$ & $\begin{array}{c}\text { Microdeformação } \\
(\%)\end{array}$ \\
\hline 110 & 25,7 & 0,337 & 9,1 & 0,72 \\
\hline 200 & 21,2 & 0,331 & 7,5 & 1,01 \\
\hline 211 & 14,2 & 0,337 & 4,9 & 0,72 \\
\hline 220 & 25,7 & 0,337 & 9,1 & 0,72 \\
\hline 310 & 12,5 & 0,333 & 5,3 & 0,91 \\
\hline 222 & 9,4 & 0,340 & 4,5 & 0,59 \\
\hline 321 & 8,4 & 0,337 & 3,0 & 0,72 \\
\hline Média & 17 & 0,336 & 6,2 & 0,77 \\
\hline $\begin{array}{l}\text { Desvio } \\
\text { Padrão } \\
\end{array}$ & 7 & 0,003 & 2,4 & 0,14 \\
\hline $\begin{array}{l}\text { Parâmetro } \\
\text { de rede }(\AA)\end{array}$ & \multicolumn{2}{|c|}{$3,3120 \pm 0,0001$} & \multicolumn{2}{|c|}{$3,3403 \pm 0,0002$} \\
\hline $\mathrm{R}_{\mathrm{wp}}(\%)$ & \multicolumn{2}{|r|}{7,93} & \multicolumn{2}{|r|}{6,75} \\
\hline $\begin{array}{l}\text { Qualidade } \\
\text { de ajuste }\end{array}$ & \multicolumn{2}{|c|}{1,148} & \multicolumn{2}{|c|}{1,197} \\
\hline
\end{tabular}


A análise do comportamento plástico de misturas com diferentes propriedades mecânicas conduz a um mecanismo de deformação plástica que explica satisfatoriamente os resultados apresentados nas TAB.14 e 15.

O alumínio é o componente majoritário nas misturas para síntese de $\mathrm{NbAl}_{3}$ e possui uma tensão de escoamento menor que o nióbio. Nas moagens de misturas de reagentes como recebidos (MCR), o alumínio absorve a maior parte da energia de impacto das esferas de moagem devido a sua maior fração volumétrica e a sua baixa resistência mecânica. No caso da mistura com apenas o nióbio pré-ativado (MPA-N) a situação é muito semelhante e o alumínio como recebido continuará absorvendo a maior parte da energia de impacto. Já no caso da mistura com apenas o alumínio pré-ativado (MPA-A), o alumínio no estado encruado absorve menos energia no impacto transferindo parte dessa energia ao nióbio como recebido. Essa situação acelera o processo de encruamento do nióbio, o que explicaria um tamanho de cristalito menor para o nióbio nas mistura do tipo MPA-A em relação à mistura do tipo MCR. O achatamento das partículas de alumínio na mistura MPA-A, observada na moagem de 20 minutos (FIG.25 p.85), que não ocorreu na mistura MPA (FIG.22 - p.82), que foi preparada com o mesmo alumínio pré-ativado. Esse achatamento pode ser o mecanismo responsável pela diminuição do tamanho de cristalito, entretanto não estão muito claras quais as condições que poderiam ter propiciado tal achatamento na mistura MPA-A.

\subsubsection{PERFIS DE TEMPERATURA}

\section{Misturas MCR, MPA e MPA-R}

Na FIG.32 estão apresentados os perfis de temperatura das misturas de reagentes como recebidos (MCR - 20 e 120 minutos de moagem), de reagentes pré-ativados (MPA - 20 e 120 minutos de moagem) e de reagentes pré-ativados e recozidos (MPA-R - 120 minutos de moagem). A TAB.16 apresenta os resultados das análises dos perfis. Observar-se nessa tabela que a taxa de aquecimento média na mistura MCR com 20 minutos de moagem é cerca de um terço da verificada na mistura MCR com 120 minutos. Esse parâmetro indica que a cinética de reação foi diferente. Entretanto, essa diferença provocou pouca influência sobre a taxa de aquecimento máxima. Outra característica que apresentou forte variação foi o tempo de fusão do alumínio, que praticamente foi reduzido pela metade na mistura MCR com 120 minutos de moagem em relação a mesma mistura com 20 minutos de moagem. 

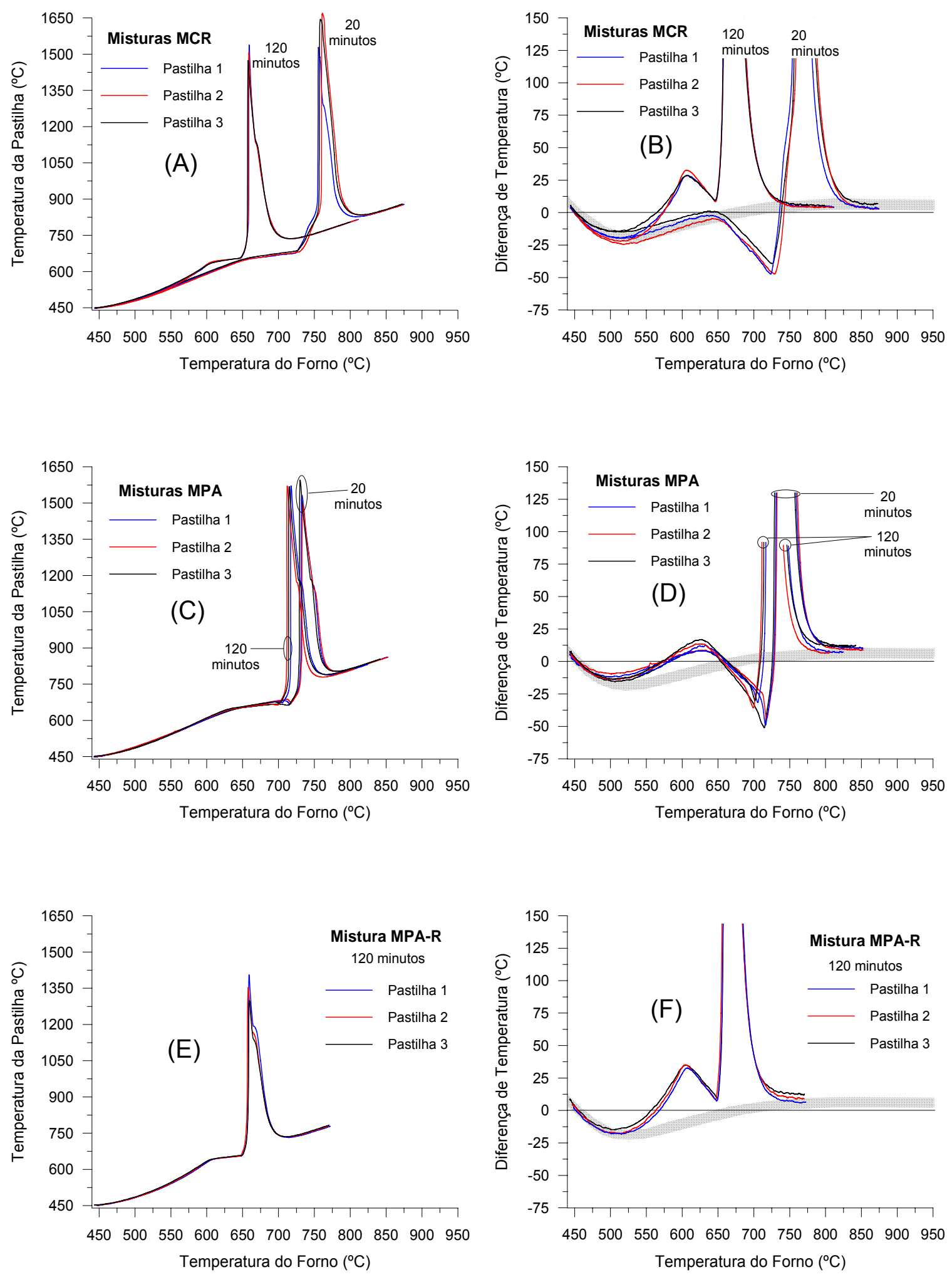

FIGURA 32 - Perfis de temperatura e de diferença de temperatura entre pastilha e forno, referentes às pastilhas preparadas a partir de misturas moídas de reagentes como recebidos, $\operatorname{MCR}(A$ e $B)$, de misturas moídas de reagentes pré-ativados, MPA (C e D), e de misturas de reagentes pré-ativados e recozidos. Tempos de moagem de 20 e 120 minutos. 
TABELA 16 -Valores característicos dos perfis de temperatura para pastilhas preparadas a partir de misturas moídas de reagentes como recebidos (MCR), pré-ativados (MPA) e pré-ativados e recozidos (MPA-R). Tempos de moagem de 20 e 120 minutos.

\begin{tabular}{|c|c|c|c|c|c|}
\hline & $\begin{array}{c}\text { MCR } \\
20 \text { minutos }\end{array}$ & $\begin{array}{c}\text { MPA } \\
20 \text { minutos }\end{array}$ & $\begin{array}{c}\text { MCR } \\
120 \text { minutos }\end{array}$ & $\begin{array}{c}\text { MPA } \\
120 \text { minutos }\end{array}$ & $\begin{array}{c}\text { MPA-R } \\
120 \text { minutos }\end{array}$ \\
\hline $\begin{array}{c}\text { Temperatura } \\
\text { de ignição }\left({ }^{\circ} \mathrm{C}\right)\end{array}$ & $681 \pm 5$ & $668 \pm 5$ & $659 \pm 1$ & $669 \pm 6$ & $657 \pm 2$ \\
\hline $\begin{array}{c}\text { Temperatura de } \\
\text { explosão térmica }\left({ }^{\circ} \mathrm{C}\right)\end{array}$ & $935 \pm 15$ & $874 \pm 10$ & $813 \pm 31$ & $805 \pm 10$ & $867 \pm 1$ \\
\hline $\begin{array}{l}\text { Temperatura de } \\
\text { Combustão }\left({ }^{\circ} \mathrm{C}\right)\end{array}$ & $1615 \pm 76$ & $1541 \pm 51$ & $1507 \pm 32$ & $1570 \pm 2$ & $1353 \pm 53$ \\
\hline$\Delta \mathrm{T}\left({ }^{\circ} \mathrm{C}\right)$ & $933 \pm 73$ & $873 \pm 55$ & $847 \pm 32$ & $901 \pm 6$ & $696 \pm 54$ \\
\hline $\begin{array}{l}\text { Taxa de aquecimento } \\
\text { máxima }\left({ }^{\circ} \mathrm{C} / \mathrm{s}\right)\end{array}$ & $1110 \pm 122$ & $1333 \pm 296$ & $1283 \pm 262$ & $1667 \pm 211$ & $412 \pm 77$ \\
\hline Tempo de reação (s) & $86 \pm 2$ & $43 \pm 1$ & $24 \pm 2$ & $35 \pm 2$ & $23 \pm 1$ \\
\hline $\begin{array}{c}\text { Taxa de aquecimento } \\
\text { média }\left({ }^{\circ} \mathrm{C} / \mathrm{s}\right)\end{array}$ & $11 \pm 1$ & $21 \pm 2$ & $36 \pm 2$ & $26 \pm 1$ & $30 \pm 2$ \\
\hline $\begin{array}{l}\text { Tempo de fusão do } \\
\text { alumínio (s) }\end{array}$ & $208 \pm 9$ & $220 \pm 5$ & $101 \pm 1$ & $196 \pm 9$ & $106 \pm 7$ \\
\hline
\end{tabular}

A análise do gráfico da diferença de temperatura entre a pastilha e o forno em função da temperatura do forno (FIG.32B) mostra que o comportamento térmico da mistura com 120 minutos de moagem não segue a faixa cinza, que corresponde ao comportamento térmico padrão esperado durante o aquecimento do sistema sem a ocorrência de reações. Quando a pastilha atinge a faixa de temperatura entre $500^{\circ} \mathrm{C}$ e $550^{\circ} \mathrm{C}$, a diferença de temperatura entre a pastilha e o forno diminui rapidamente até zero e passa para o campo positivo até atingir um valor máximo em torno de $30^{\circ} \mathrm{C}$ no início da fusão do alumínio. Esse comportamento térmico indica a ocorrência de alguma reação exotérmica na pastilha, e parece provável se tratar da formação de $\mathrm{NbAl}_{3}$ por difusão no estado sólido.

A diminuição do tempo de fusão do alumínio decorre da menor quantidade de alumínio devido à formação de $\mathrm{NbAl}_{3}$ por difusão e da energia adicional liberada com a formação do intermetálico. Tal situação diminui a quantidade de reagentes disponíveis para a reação de combustão, provocando uma queda na temperatura de combustão. 
A avaliação microestrutural das misturas do tipo MPA, apresentada no item 5.2.1 (FIG.23 - p.83), revelou que a moagem de misturas de reagentes préativados gera agregados de alumínio com partículas de nióbio incrustadas. A homogeneidade da dispersão das partículas de nióbio aumenta com o tempo de moagem, porém a forma das partículas foi mantida, o que produziu microestruturas muito semelhantes entre as misturas com moagem de 20 e 120 minutos. Essa semelhança microestrutural se refletiu no comportamento térmico das pastilhas preparadas a partir dessas misturas (FIG.32C e D). As temperaturas de ignição e as temperaturas máximas de reação foram muito semelhantes para os dois tempos de moagem, porém a mistura com moagem de 120 minutos apresentou uma cinética de reação um pouco maior.

A pastilha preparada com a mistura moída a partir de reagentes préativados e recozidos (MPA-R - 120 minutos de moagem) apresentou um comportamento térmico bem diferente da mistura de reagentes pré-ativados (MPA) e muito semelhante à mistura de reagentes como recebidos (MCR). A análise da microestrutura das partículas da mistura MPA-R (FIG.24 - p.84) mostrou que a condição de distribuição do nióbio nos agregados é intermediária às apresentadas pelas misturas MCR e MPA (FIG.23 - p.83), e que as partículas de nióbio foram deformadas durante a moagem. A similaridade de comportamento térmico entre as misturas MCR e MPA-R, com 120 minutos de moagem, é um indício de que é necessária a deformação tanto do alumínio como do nióbio para formar uma interface mais reativa.

\section{Misturas MPA-A e MPA-N}

Os perfis de temperatura das misturas dos tipos MPA-A e MPA-N estão apresentados na FIG.33. Os resultados das análises dos perfis estão dispostos na TAB.17. A mistura moída de alumínio pré-ativado e nióbio como recebido (MPA-A) apresentou um comportamento térmico muito diferente para os dois tempos de moagem estudados. A forte tendência de formação de estruturas lamelares nessa mistura provocou um significativo aumento da área de interface entre os reagentes, na moagem por 120 minutos, potencializando o efeito do aquecimento da pastilha antes do patamar de fusão do alumínio, e reduzindo a temperatura de ignição para $542^{\circ} \mathrm{C}$. Os resultados de taxa de aquecimento máxima, tanto nas misturas MPA-A como nas misturas MPA-N, seguem o 
comportamento já observado anteriormente, que vincula o aumento da cinética da reação à redução do tamanho médio de partícula do nióbio.

O tempo de fusão do alumínio da mistura MPA-A foi significativamente menor que o observado na mistura MPA-N, sendo quase imperceptível no perfil apresentado na FIG.33A e B. Esse resultado, assim como o observado nas misturas MCR, MPA e MPA-R, mostra que a deformação conjunta do nióbio com o alumínio e a formação de agregados lamelares é uma condição muito importante na formação de interfaces com alta reatividade.
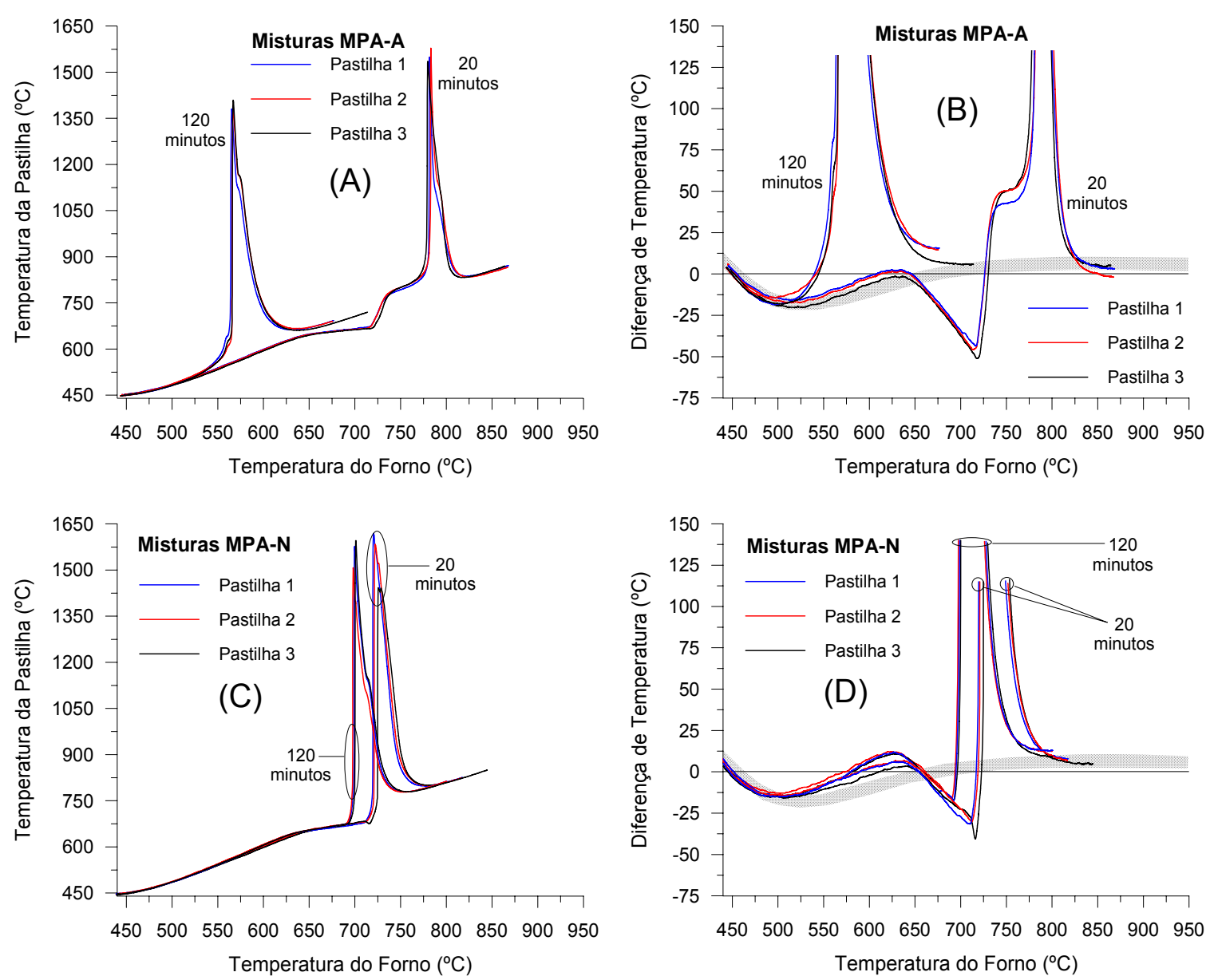

FIGURA 33 - Perfis de temperatura e de diferença de temperatura entre pastilha e forno, referentes às pastilhas preparadas a partir de misturas moidas com apenas o alumínio no estado pré-ativado, SPA-A (A e $B)$, e de misturas moídas com apenas o nióbio no estado préativado, SPA-N (C e D). Tempos de moagem de 20 e 120 minutos. 
TABELA 17 -Valores característicos dos perfis de temperatura das pastilhas preparadas a partir de misturas moídas com apenas o alumínio no estado pré-ativado (SPA-A) e de misturas moídas com apenas o nióbio no estado pré-ativado (SPA-N). Tempos de moagem de 20 e 120 minutos.

\begin{tabular}{|c|c|c|c|c|}
\hline & $\begin{array}{c}\text { MPA-A } \\
20 \text { minutos }\end{array}$ & $\begin{array}{c}\text { MPA-N } \\
20 \text { minutos }\end{array}$ & $\begin{array}{c}\text { MPA-A } \\
120 \text { minutos }\end{array}$ & $\begin{array}{c}\text { MPA-N } \\
120 \text { minutos }\end{array}$ \\
\hline $\begin{array}{c}\text { Temperatura } \\
\text { de ignição }\left({ }^{\circ} \mathrm{C}\right)\end{array}$ & $834 \pm 6$ & $682 \pm 4$ & $542 \pm 3$ & $678 \pm 1$ \\
\hline $\begin{array}{c}\text { Temperatura de } \\
\text { explosão térmica }\left({ }^{\circ} \mathrm{C}\right)\end{array}$ & $987 \pm 24$ & $780 \pm 19$ & $699 \pm 32$ & $817 \pm 25$ \\
\hline $\begin{array}{l}\text { Temperatura de } \\
\text { Combustão }\left({ }^{\circ} \mathrm{C}\right) \\
\end{array}$ & $1555 \pm 22$ & $1549 \pm 93$ & $1395 \pm 14$ & $1560 \pm 47$ \\
\hline$\Delta \mathrm{T}\left({ }^{\circ} \mathrm{C}\right)$ & $720 \pm 20$ & $867 \pm 91$ & $852 \pm 12$ & $882 \pm 46$ \\
\hline $\begin{array}{l}\text { Taxa de aquecimento } \\
\text { máxima }\left({ }^{\circ} \mathrm{C} / \mathrm{s}\right)\end{array}$ & $511 \pm 64$ & $1244 \pm 266$ & $942 \pm 74$ & $1138 \pm 169$ \\
\hline Tempo de reação (s) & $27 \pm 2$ & $23 \pm 2$ & $50 \pm 4$ & $17 \pm 1$ \\
\hline $\begin{array}{c}\text { Taxa de aquecimento } \\
\text { média }\left({ }^{\circ} \mathrm{C} / \mathrm{s}\right)\end{array}$ & $26 \pm 1$ & $38 \pm 2$ & $17 \pm 2$ & $51 \pm 2$ \\
\hline $\begin{array}{l}\text { Tempo de fusão do } \\
\text { alumínio (s) }\end{array}$ & $213 \pm 4$ & $213 \pm 3$ & $6,3 \pm 0,3$ & $167 \pm 7$ \\
\hline
\end{tabular}

\subsubsection{MICROESTRUTURA DAS PASTILHAS}

\section{Misturas MCR, MPA e MPA-R}

As micrografias das pastilhas preparadas a partir de misturas de reagentes como recebidos (MCR), de reagentes pré-ativados (MPA) e de reagentes préativados e recozidos (MPA-R) estão apresentadas nas FIG.34 a 36. As pastilhas reagidas do tipo MCR apresentaram uma microestrutura formada por uma matriz de $\mathrm{NbAl}_{3}$, partículas brancas ricas em nióbio, partículas cinza escuro ricas em alumínio. Algumas regiões próximas à superfície e, também, na própria superfície apresentaram a formação do eutético $\mathrm{NbAl}_{3}-\mathrm{Nb}_{2} \mathrm{Al}$, indicando que houve um desvio da estequiometria da mistura com perda de alumínio. Segundo o diagrama Al-Nb a temperatura do eutético é de $1590^{\circ} \mathrm{C}$, o que corrobora os valores de temperatura máxima de reação, registrados nessas pastilhas. A quantidade de óxidos e carbonetos foi significativamente menor que a verificada nas pastilhas preparadas a partir de pós pré-ativados, evidenciando um menor grau de decomposição do ACP na moagem de 20 minutos. 
A análise da microestrutura das pastilhas reagidas (MCR - 120 minutos) revelou um aumento da quantidade de óxidos e carbonetos e a presença de uma pequena fração de alumínio não reagido. A ausência do eutético e a presença de alumínio não reagido indicam um desvio da estequiometria da mistura oposto ao verificado nas pastilhas de misturas com 20 minutos de moagem, ou seja, houve falta de nióbio para completar a reação. Essa deficiência de nióbio pode estar associada à precipitação mais intensa de carbonetos de nióbio.

A utilização de reagentes pré-ativados afeta sensivelmente a distribuição dos elementos reagentes durante o processo de moagem da mistura. Nas pastilhas MPA, as partículas de nióbio se concentram ao redor das partículas de alumínio; com o processo de moagem, a dispersão do nióbio é sensivelmente melhorada. A comparação das micrografias D e H da FIG. 35 evidencia uma quantidade maior de $\mathrm{NbAl}_{3}$, formado antes da reação, na moagem mais longa, sugerindo que o aumento do tempo de moagem melhora o contato das interfaces Al-Nb. A microestrutura da pastilha reagida (FIG.35E e F) é semelhante à observada na pastilha MCR com 120 minutos de moagem (FIG.34E e F), constatando-se apenas uma quantidade maior de óxidos e carbonetos.

A redução da resistência mecânica das partículas de nióbio e de alumínio pela aplicação de um tratamento de recozimento dos pós pré-ativados (MPA-R) permitiu uma deformação maior das partículas de nióbio durante a moagem da mistura, como pode ser observado nas micrografias C e D da FIG.36. A comparação das micrografias FIG.36D e FIG.35H sugere uma formação de $\mathrm{NbAl}_{3}$ mais intensa na pastilha MPA-R, sendo que a deformação do nióbio durante a moagem parece ser um fator importante nas condições de formação de $\mathrm{NbAl}_{3}$ por difusão. 


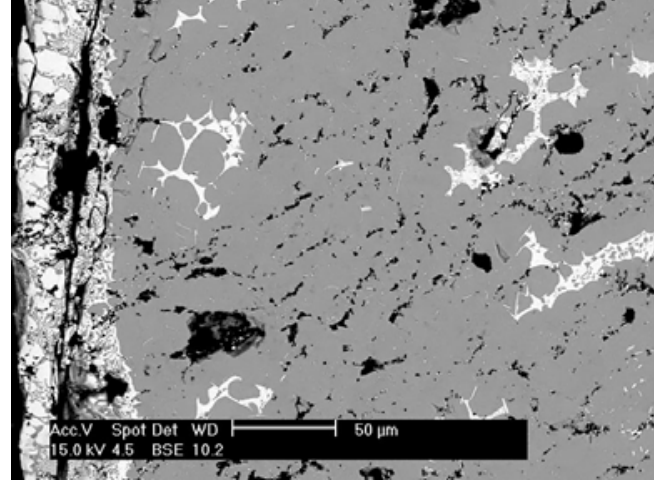

(A) reagida -20 minutos

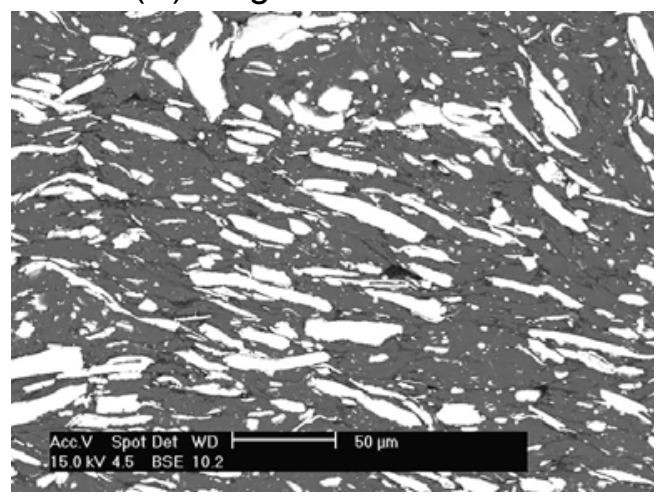

(C) antes da reação -20 minutos

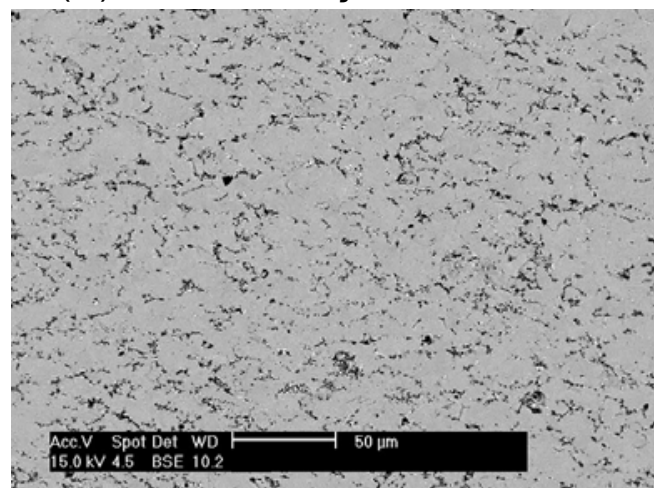

(E) reagida -120 minutos

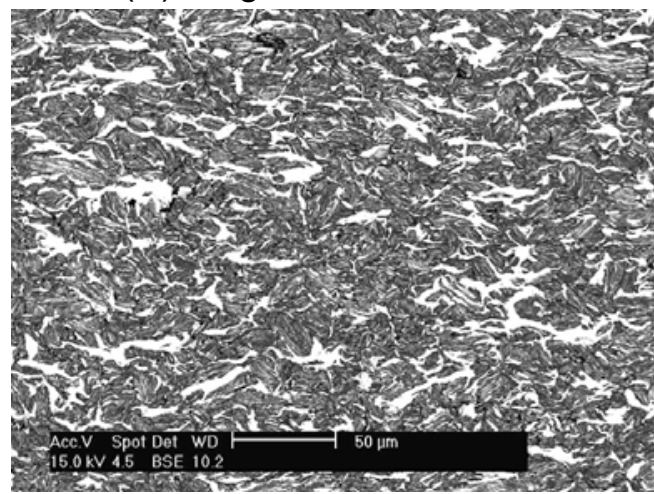

(G) antes da reação - 120 minutos

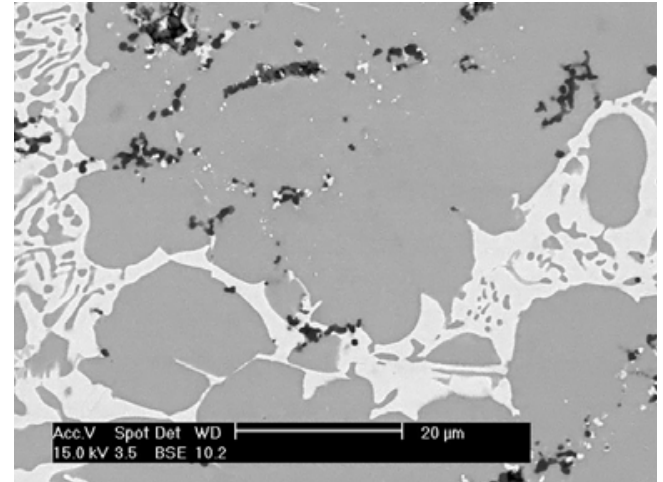

(B) reagida -20 minutos

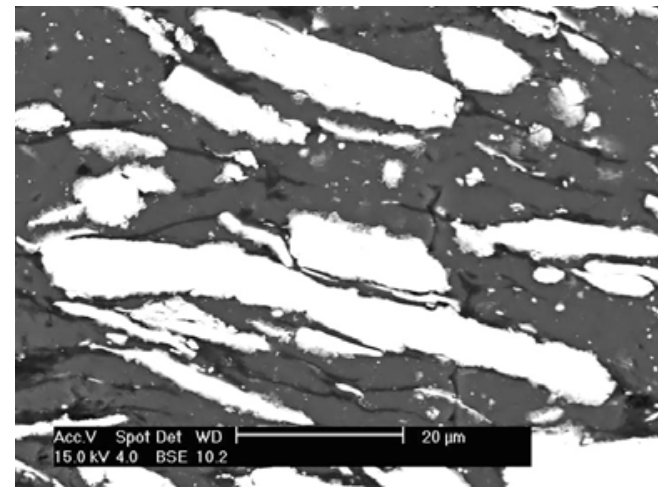

(D) antes da reação -20 minutos

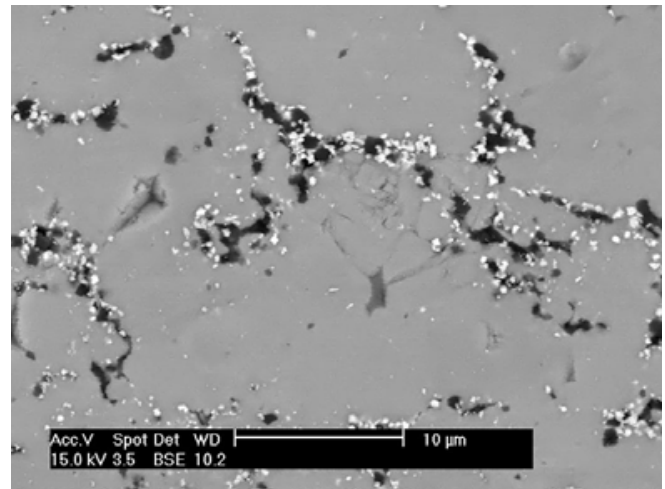

(F) reagida -120 minutos

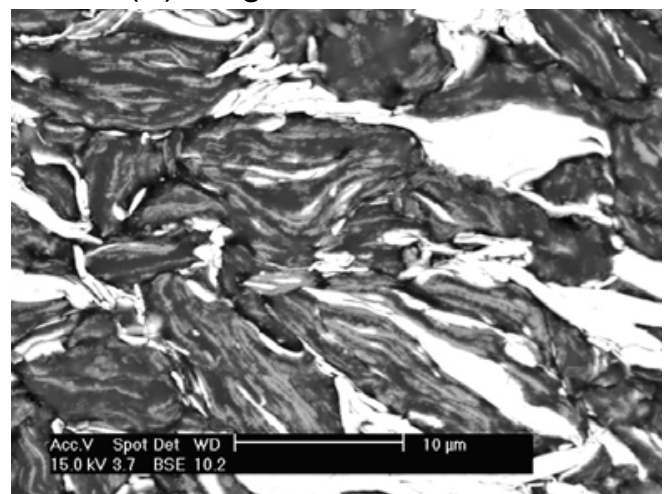

(H) antes da reação -120 minutos

FIGURA 34 - Micrografias de pastilhas reagidas e de pastilhas com interrupção de aquecimento antes da ignição referentes às misturas de reagentes como recebidos (MCR) com 20 e 120 minutos de moagem. Microscopia eletrônica de varredura com imagem de elétrons retroespalhados. 


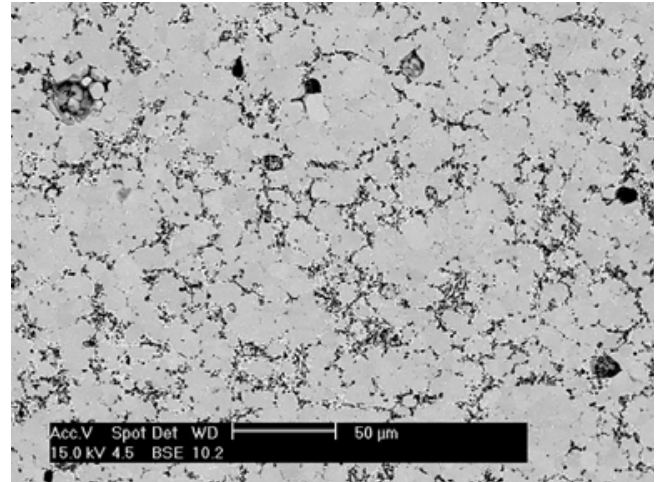

(A) reagida - 20 minutos

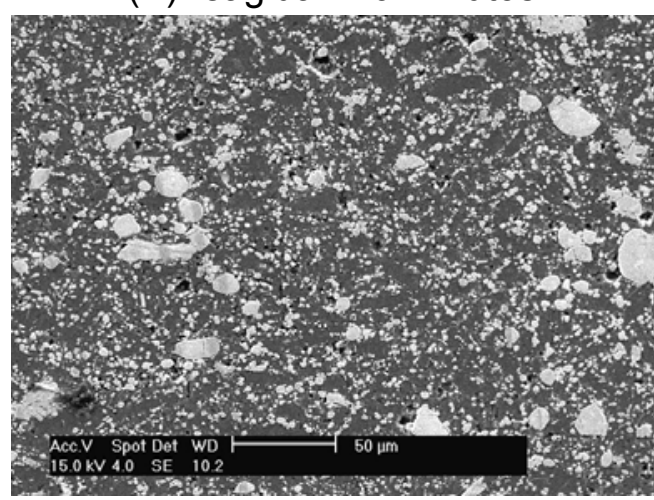

(C) antes da reação - 20 minutos

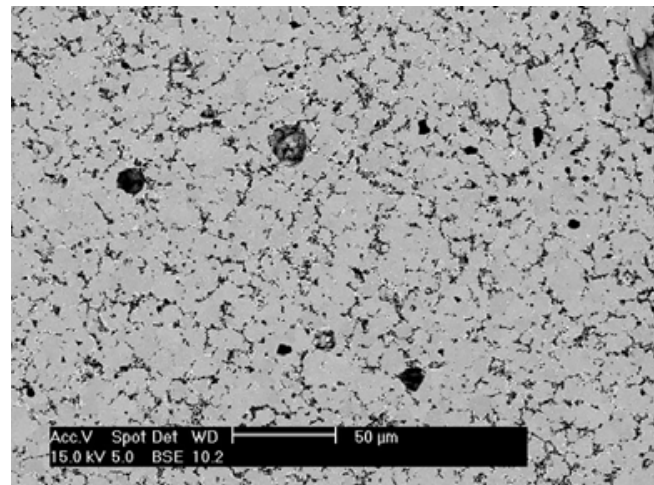

(E) reagida - 120 minutos

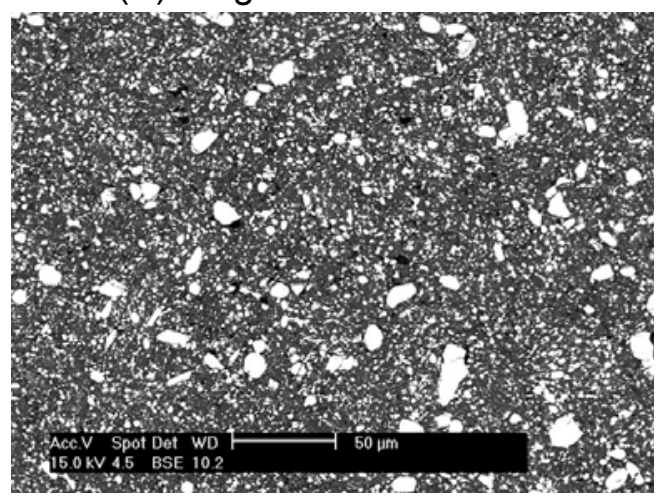

(G) antes da reação - 120 minutos

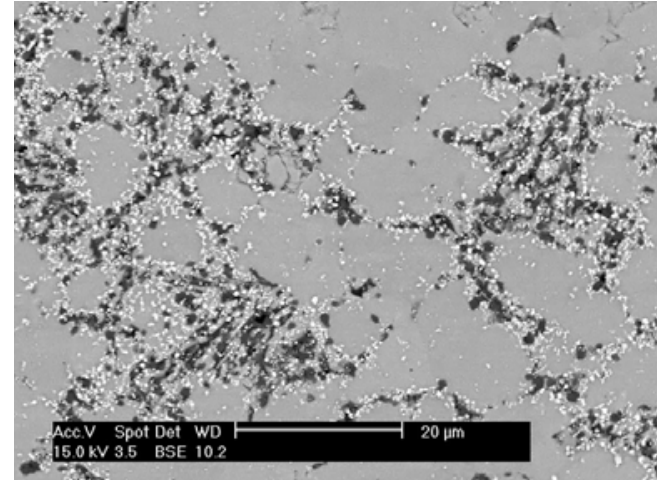

(B) reagida - 20 minutos

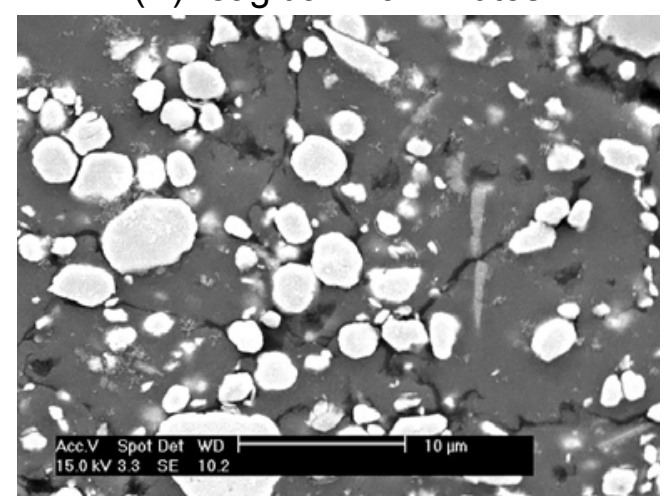

(D) antes da reação - 20 minutos

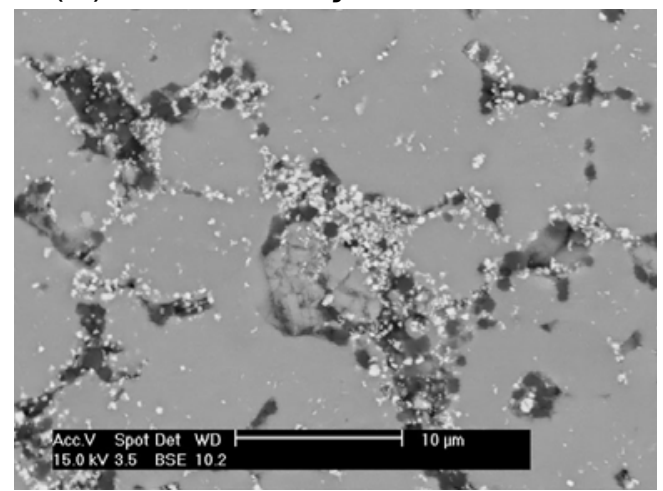

$(\mathrm{F})$ reagida - 120 minutos

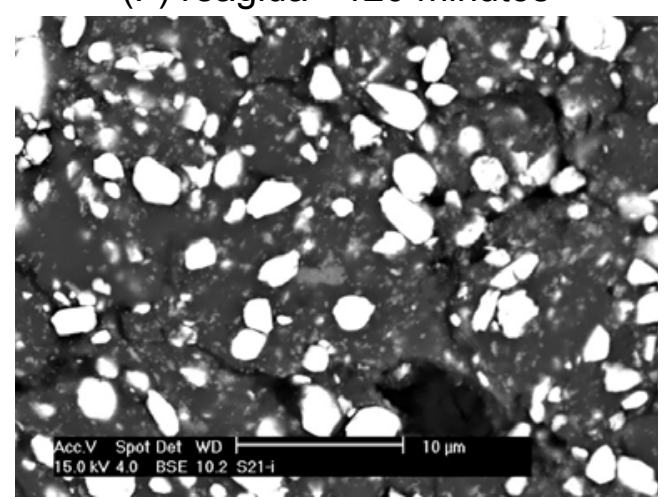

(H) antes da reação - 120 minutos

FIGURA 35 - Micrografias de pastilhas reagidas e de pastilhas com interrupção de aquecimento antes da ignição referentes às misturas de reagentes pré-ativados (MPA) com 20 e 120 minutos de moagem. Microscopia eletrônica de varredura com imagem de elétrons retroespalhados. 


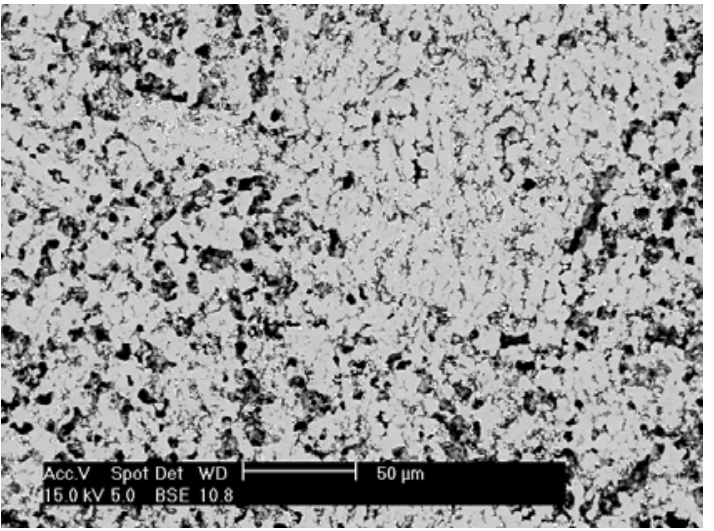

(A) reagida

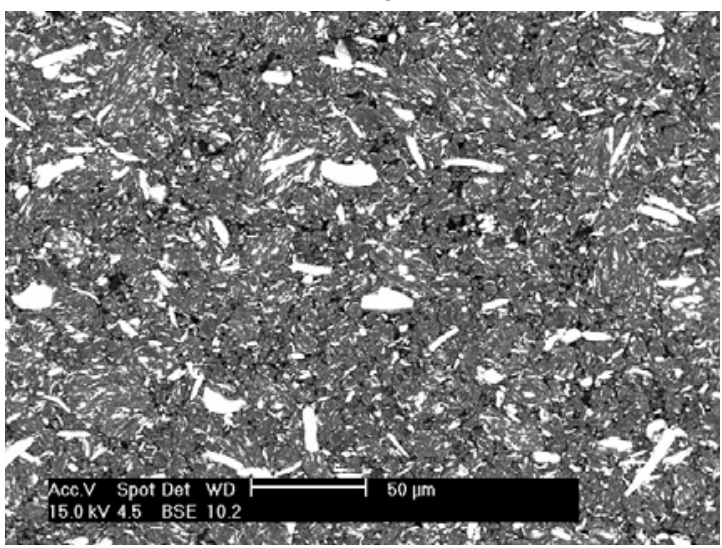

(C) antes da reação

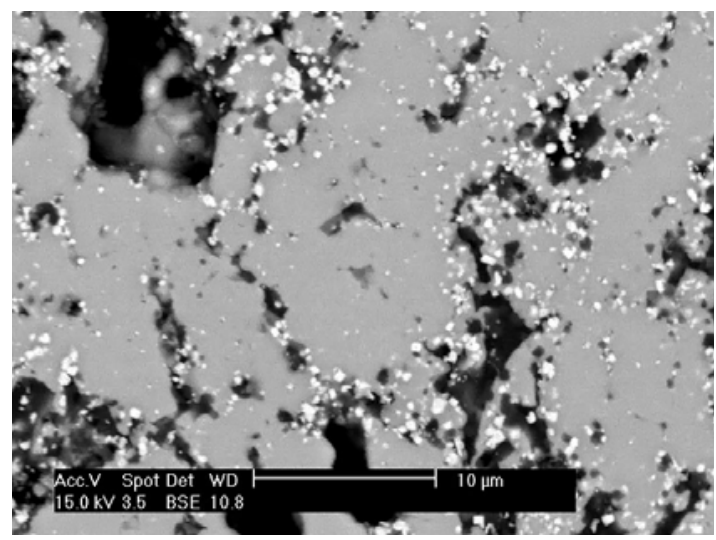

(B) reagida

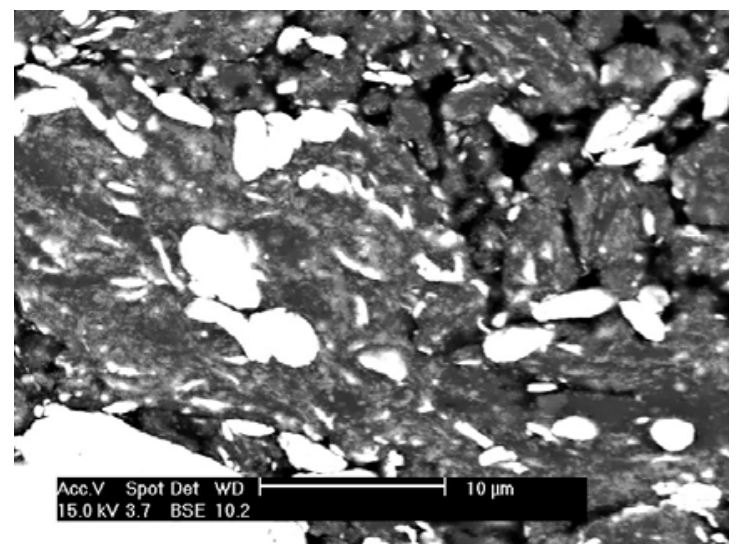

(D) antes da reação

FIGURA 36 - Micrografias de pastilhas reagidas e de pastilhas com interrupção de aquecimento antes da ignição referentes às misturas de reagentes pré-ativados e recozidos (MPA-R) com 120 minutos de moagem. Microscopia eletrônica de varredura com imagem de elétrons retroespalhados.

\section{Misturas MPA-A e MPA-N}

As microestruturas das pastilhas preparadas a partir da mistura de nióbio como recebido e alumínio pré-ativado (MPA-A) e da mistura de nióbio pré-ativado e alumínio como recebido (MPA-N), estão apresentadas nas FIG.37 e 38 . A utilização de nióbio como recebido confere às pastilhas MCR e MPA-A, com 20 minutos de moagem, uma microestrutura semelhante entre si, com distribuição lamelar dos reagentes (FIG.34C e 37C). As microestruturas das pastilhas reagidas, no entanto, são diferentes. As pastilhas MPA-A apresentaram uma quantidade de carbonetos e óxidos muito superior às pastilhas MCR. Por outro lado, não foi observada a presença do eutético $\mathrm{NbAl}_{3}-\mathrm{Nb}_{2} \mathrm{Al}$ nas pastilhas MPA-A. Essa ausência do eutético se deve a temperatura de combustão menor dessas pastilhas. 


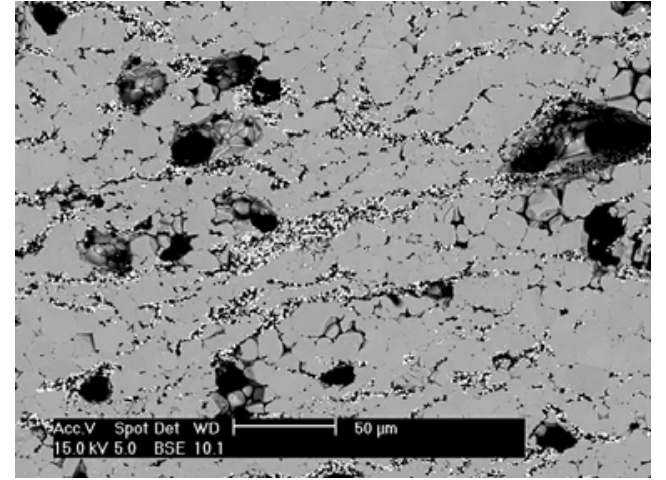

(A) MPA-A reagida

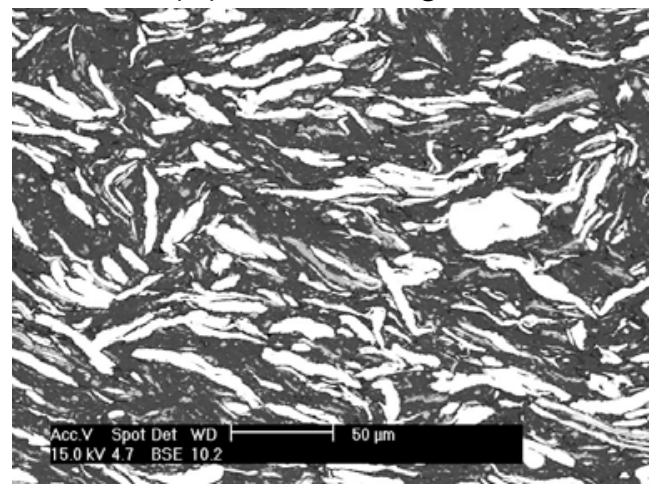

(C) MPA-A antes da reação

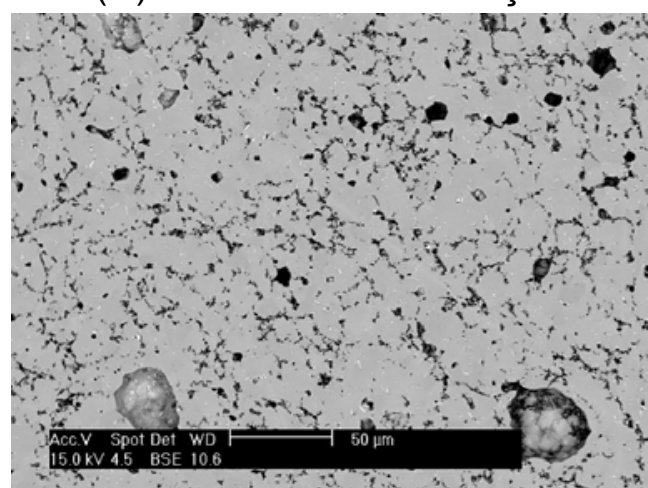

(E) MPA-N reagida

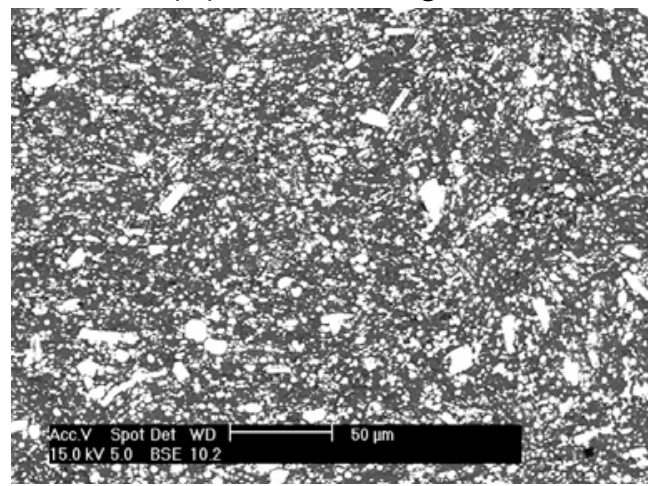

(G) MPA-N antes da reação

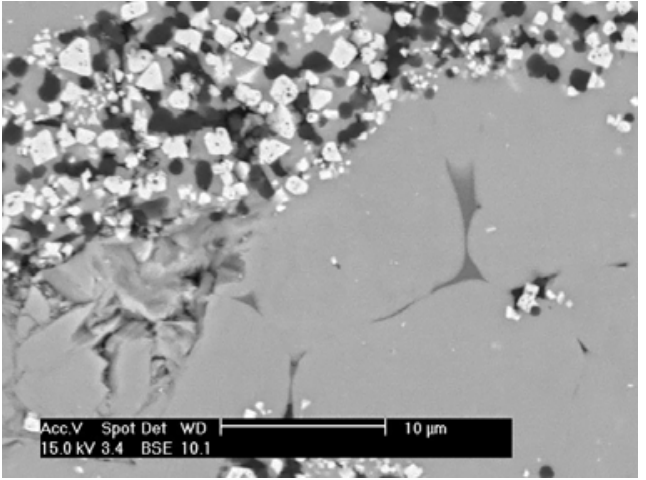

(B) MPA-A reagida

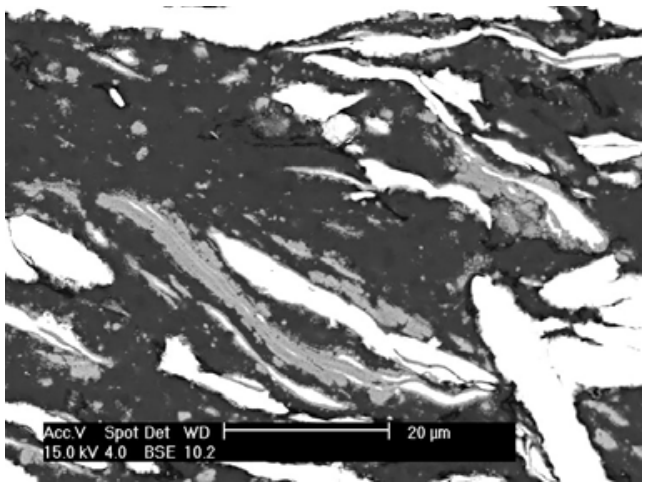

(D) MPA-A antes da reação

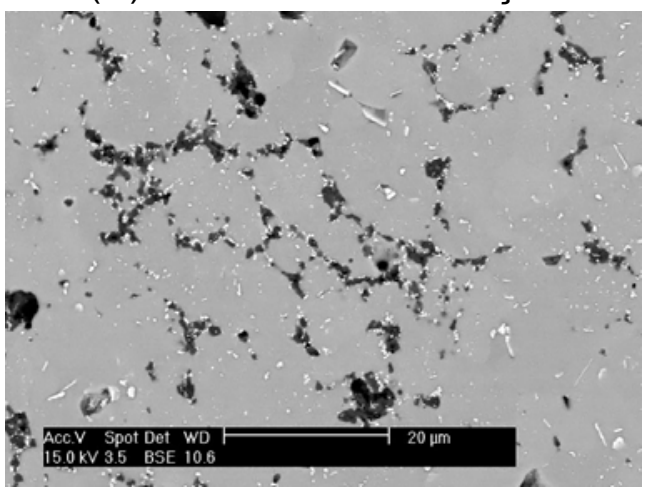

(F) MPA-N reagida

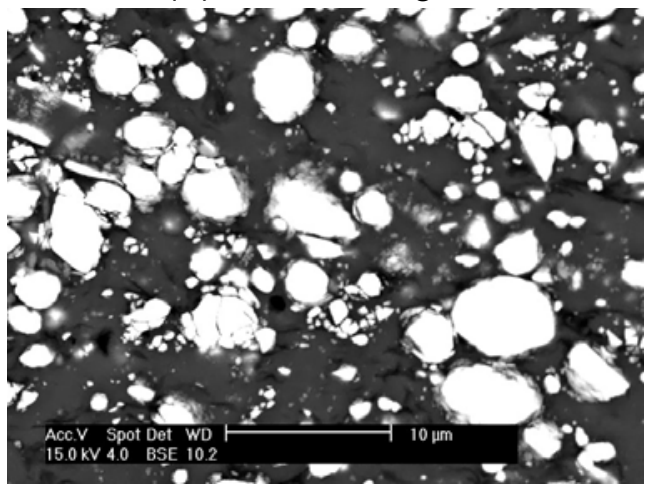

(H) MPA-N antes da reação

FIGURA 37 - Micrografias de pastilhas reagidas e de pastilhas com interrupção de aquecimento antes da ignição referentes às misturas MPA-A (alumínio pré-ativado e nióbio como recebido) e MPA-N (Alumínio como recebido e nióbio pré-ativado) com 20 minutos de moagem. Microscopia eletrônica de varredura com imagem de elétrons retroespalhados. 


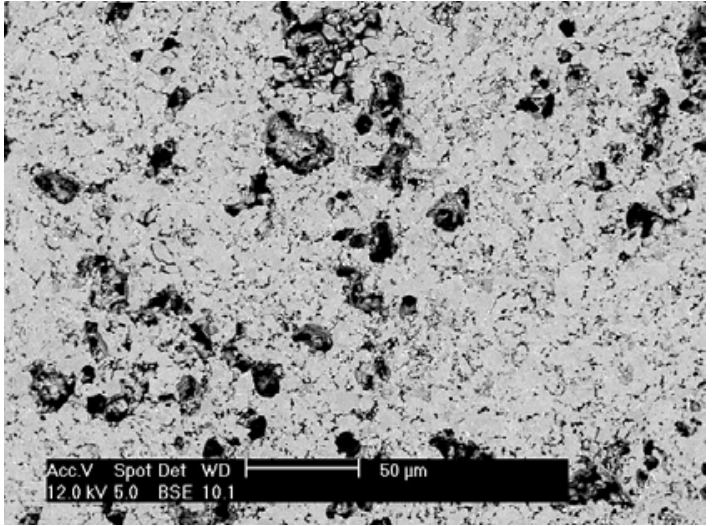

(A) MPA-A reagida

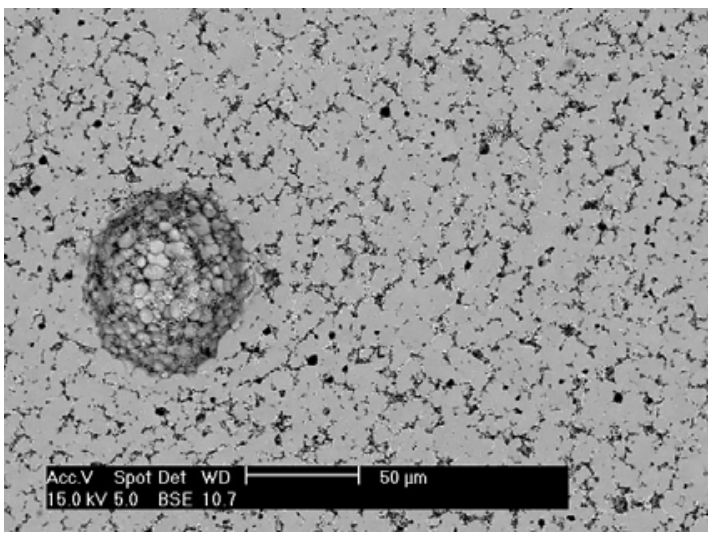

(C) MPA-N reagida

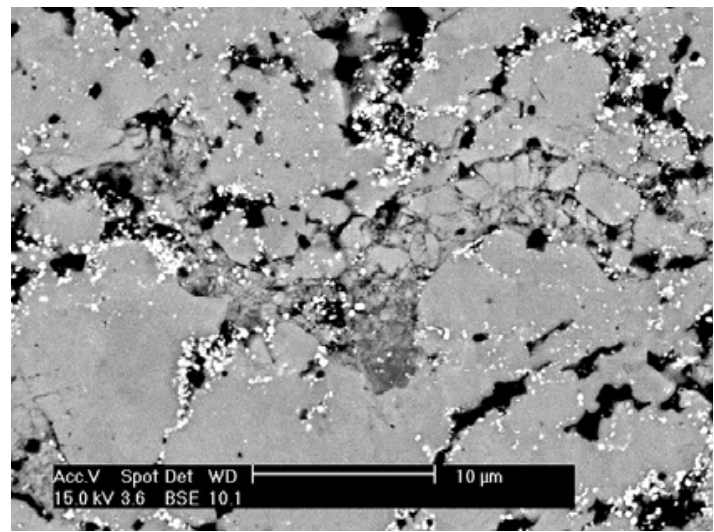

(B) MPA-A reagida

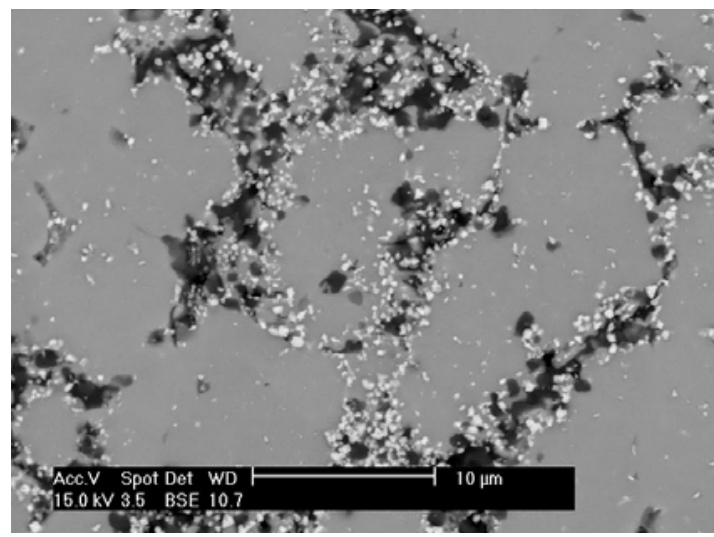

(D) MPA-N reagida

FIGURA 38 - Micrografias de pastilhas reagidas referentes às misturas MPA-A (alumínio pré-ativado e nióbio como recebido) e MPA-N (Alumínio como recebido e nióbio pré-ativado) com 120 minutos de moagem. Microscopia eletrônica de varredura com imagem de elétrons retroespalhados.

No caso das misturas com 120 minutos de moagem, as pastilhas MCR e MAP-A apresentaram microestruturas semelhantes entre si após a reação, com uma porosidade maior nas pastilhas MPA-A. A temperatura de combustão menor e a ignição da reação ocorrendo antes da fusão do alumínio, podem ter comprometido a formação de fase líquida durante a reação, prejudicando a densificação.

As pastilhas MPA e MPA-N apresentaram, após a reação, microestruturas muito semelhantes, independente do tempo de moagem (FIG.35A, B, E e F; FIG.38C e D). A semelhança também foi verificada na distribuição dos reagentes na mistura após a moagem (FIG.23 e 28 - p.83 e 88) e no comportamento térmico durante o ciclo de aquecimento (TAB.16 e 17 - p.99 e 102). 


\subsection{MISTURAS MOÍDAS COM 1,0\% DE ACP (M1)}

Os resultados obtidos neste primeiro conjunto de experimentos e expostos nos próximos itens permitiram as seguintes constatações:

a. A redução da quantidade de ACP de 1,9\% para $1 \%$ aumentou a cinética de formação de agregados de alumínio e nióbio;

b. A moagem com $1 \%$ de ACP por 120 minutos produziu uma microestrutura lamelar mais fina e homogênea nos agregados em relação à moagem com $1,9 \%$ de ACP;

c. O refino da microestrutura dos agregados na mistura com $1 \%$ de ACP moída por 120 minutos reduziu a temperatura de ignição para $541^{\circ} \mathrm{C}$;

d. A formação de $\mathrm{NbAl}_{3}$ por difusão foi maior na mistura com $1 \%$ de $\mathrm{ACP}$ em relação à mistura com $1,9 \%$ de $\mathrm{ACP}$.

\subsubsection{MICROSCOPIA E DISTRIBUIÇÃO GRANULOMÉTRICA}

As micrografias de pó solto das misturas preparadas a partir de pós como recebidos com 1,0\% de ACP (M1CR) e com 1,9\% de ACP (MCR), após 20 e 120 minutos de moagem, estão apresentadas na FIG.39. As micrografias de pó embutido estão apresentadas na FIG.40.

A adição de uma quantidade maior de ACP produziu efeitos tanto sobre a formação de agregados quanto na distribuição do tamanho de partícula. Para tempos curtos não é possível determinar diferenças representativas por microscopia. Entretanto, para tempos de moagem mais longos as diferenças entre amostras são maiores. O tamanho das partículas é menor quando se utiliza uma quantidade maior de ACP. Essa diferença foi quantificada e está apresentada na FIG.39E e F. A presença de uma quantidade maior de partículas isoladas de nióbio foi constatada na análise de vários campos de observação da amostra com $1,9 \%$ de ACP (MCR). A microestrutura dos agregados de $\mathrm{Nb}-\mathrm{Al}$ também apresentou diferenças quanto a forma de distribuição do nióbio, sendo essa distribuição mais lamelar para uma menor quantidade de ACP. 


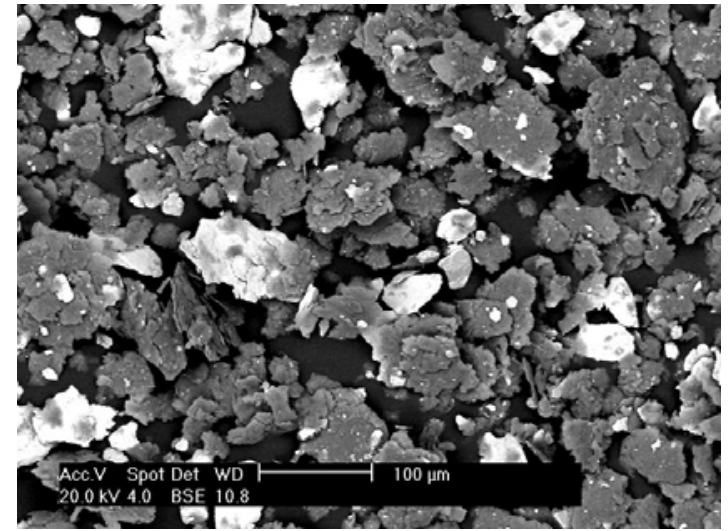

(A) 20 minutos $-1 \%$ de ACP

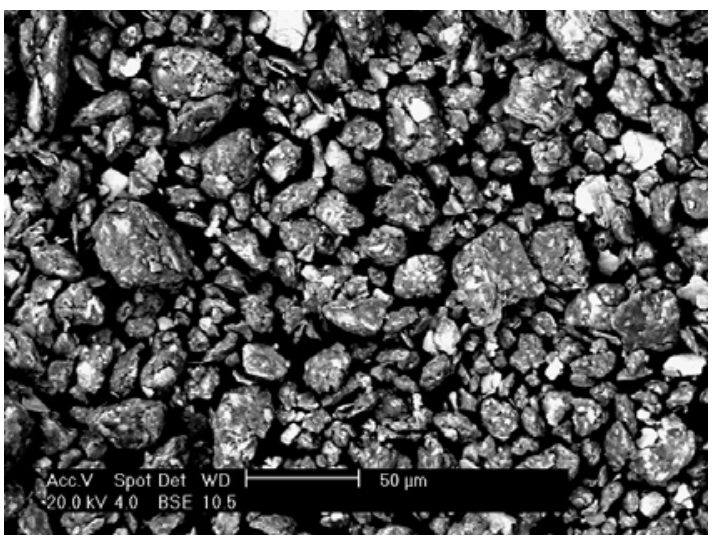

(C) 120 minutos - $1 \%$ de ACP

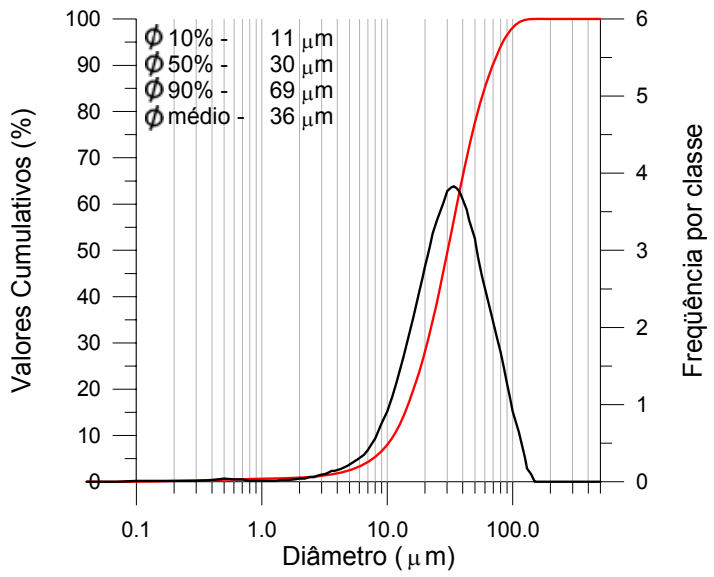

(E)120 minutos - $1 \%$ de ACP

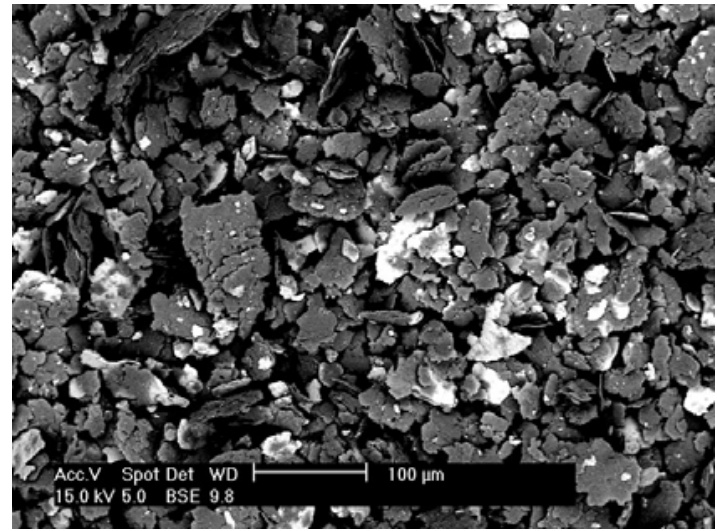

(B) 20 minutos $-1,9 \%$ de ACP

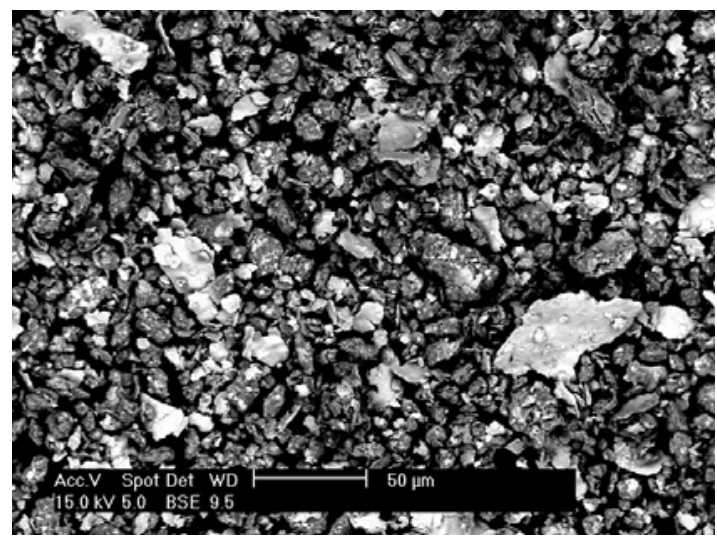

(D) 120 minutos $-1,9 \%$ de ACP

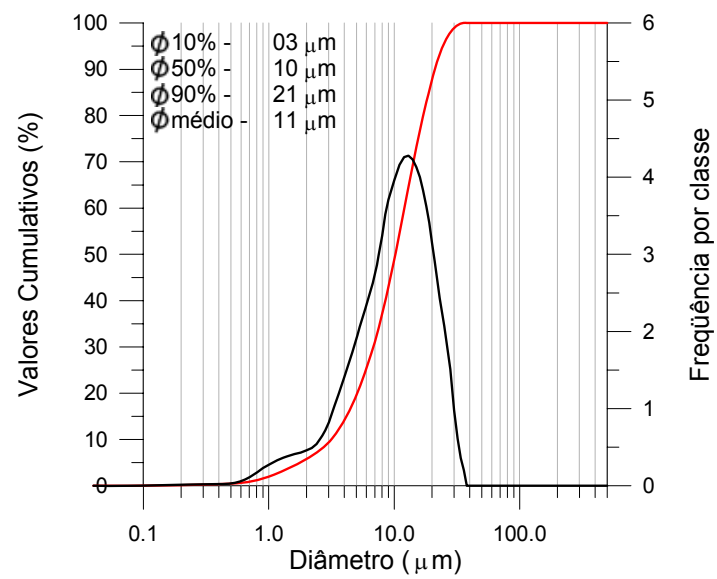

(F)120 minutos $-1,9 \%$ de ACP s

FIGURA 39 - Micrografias de pó solto de misturas preparadas a partir de pós como recebidos com 1,0\% de ACP (M1CR) e com 1,9\% de ACP (MCR), após 20 e 120 minutos de moagem, e distribuição granulométrica das misturas com 120 minutos de moagem. Microscopia eletrônica de varredura com imagem de elétrons retroespalhados. 


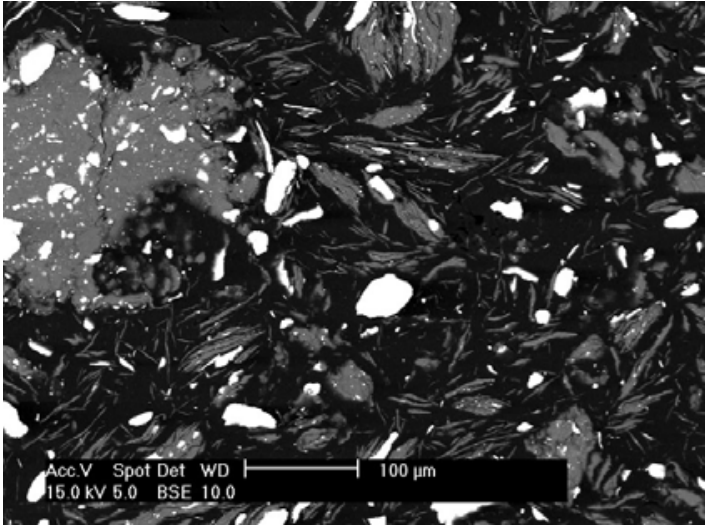

(A) 20 minutos - $1 \%$ de ACP

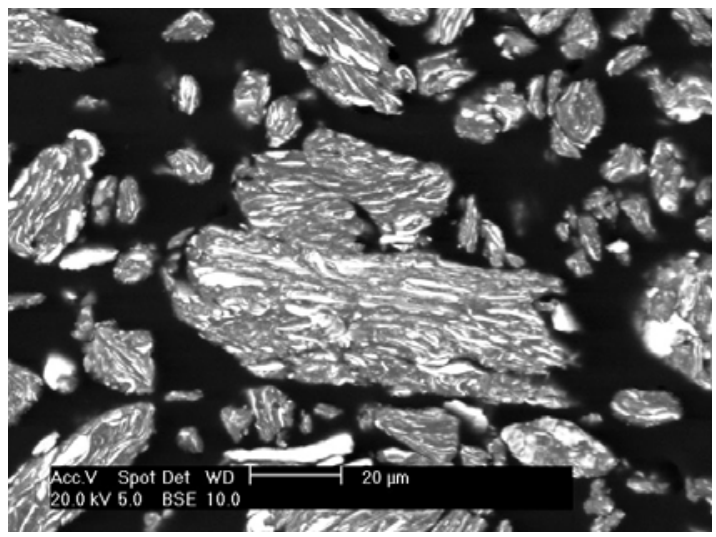

(C) 120 minutos - $1 \%$ de ACP

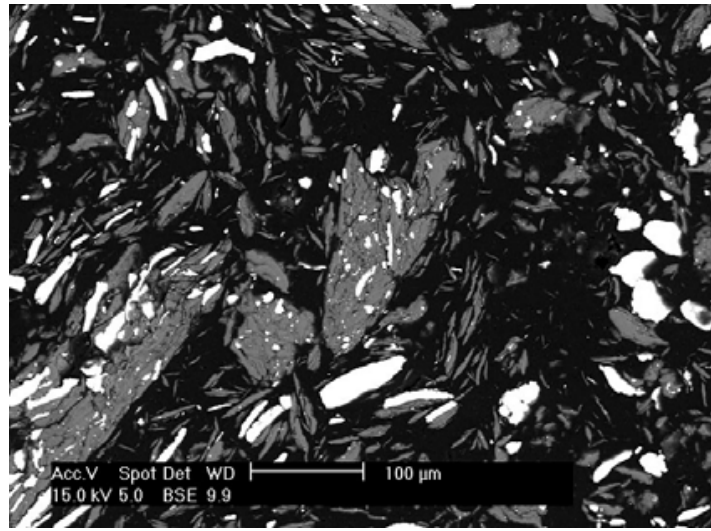

(B) 20 minutos $-1,9 \%$ de ACP

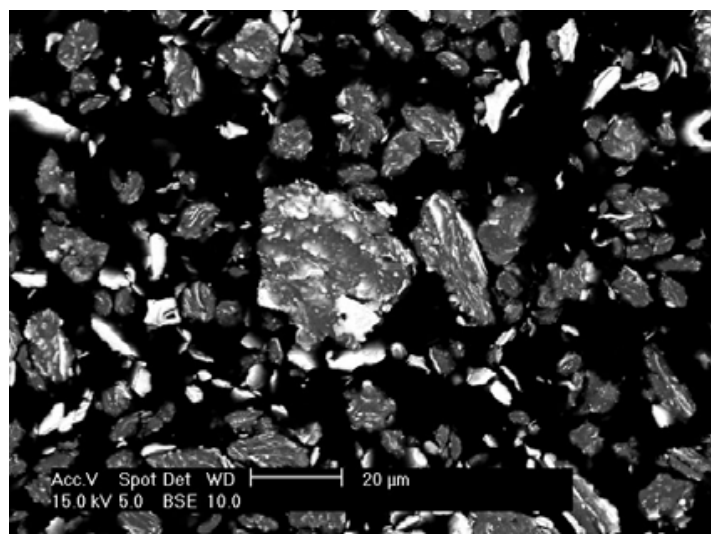

(D) 120 minutos $-1,9 \%$ de ACP

FIGURA 40 - Micrografias de pó embutido de misturas preparadas a partir de pós como recebidos com $1,0 \%$ de ACP (M1CR) e com 1,9\% de ACP (MCR), após 20 e 120 minutos de moagem. Microscopia eletrônica de varredura com imagem de elétrons retroespalhados.

\subsubsection{DIFRAÇÃO DE RAIOS X}

As misturas com 1\% de ACP (M1CR) com 20 e 120 minutos de moagem foram caracterizadas por difração de raios-X e os difratogramas estão apresentados na FIG.41. O valores relativos ao parâmetro de rede, tamanho de cristalito e microdeformação estão apresentados nas TAB.18 a 21. Os resultados da mistura com 1,9\% de ACP (MCR), obtidos no item 5.2.2, foram inseridos nas TAB. 18 a 21 para facilitar a comparação de resultados.

O refinamento do difratograma relativo à mistura $\mathrm{M} 1 \mathrm{CR}$ com 120 minutos de moagem considerou a presença da fase $\mathrm{Nb}(\mathrm{H})$. Constatou-se que o parâmetro de rede da fase $\mathrm{Nb}(\mathrm{H})$ aumenta com a maior oferta de hidrogênio proveniente do ACP. O nióbio também apresentou um pequeno aumento no parâmetro de rede, indicando a formação de solução sólida homogênea. Para o alumínio, a variação na quantidade de ACP não produziu efeito sobre o parâmetro de rede. 

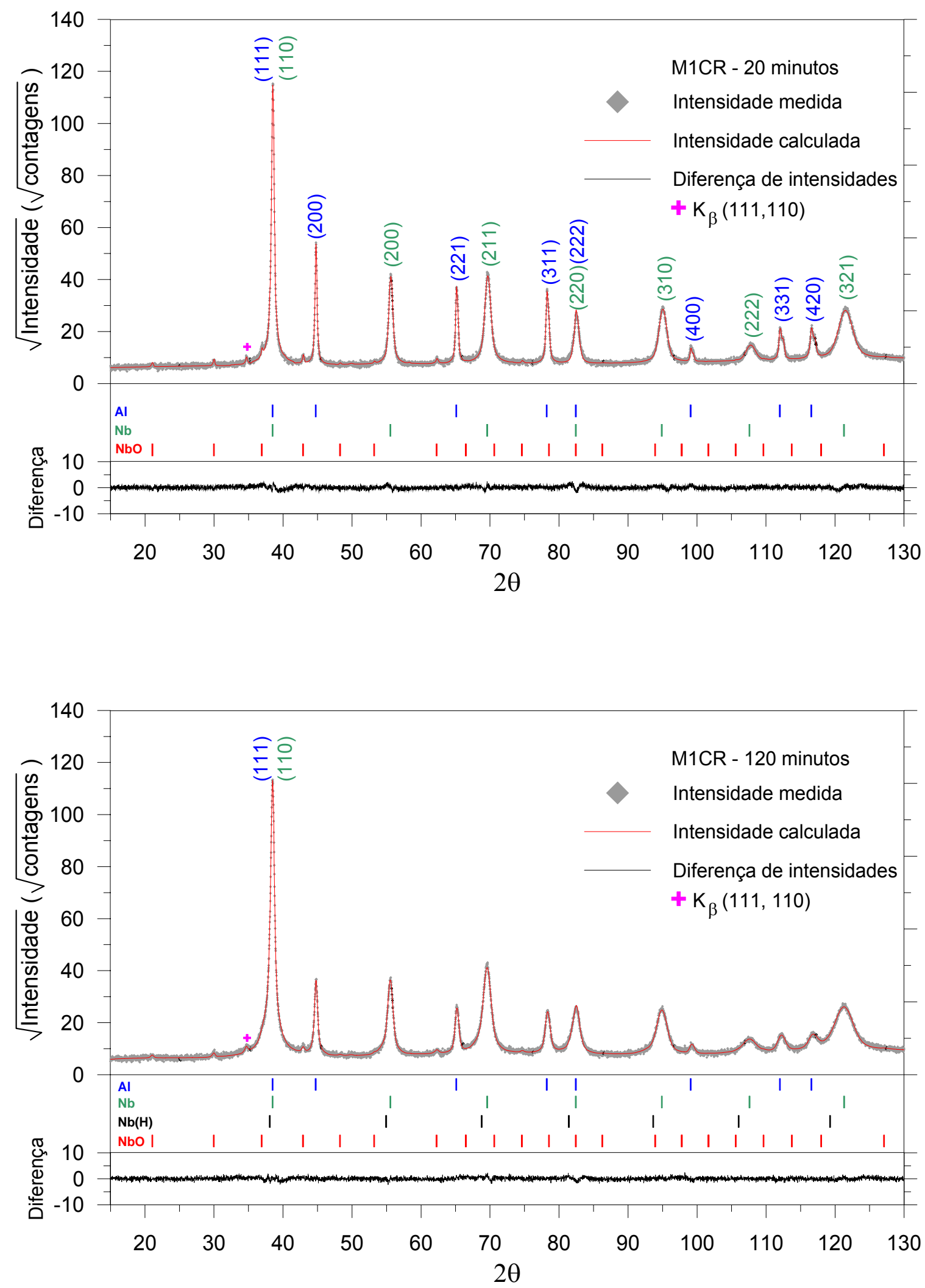

FIGURA 41 - Difratogramas de misturas moídas com 1\% de ACP, preparadas a partir de reagentes como recebidos (M1CR) após 20 e 120 minutos de moagem. Tempos de moagem de 20 e 120 minutos. 
TABELA 18 -Tamanho de cristalito, microdeformação e parâmetro de rede do alumínio em misturas moídas com 1,0\%(M1CR) e 1,9\%(MCR) de ACP, após moagem de 20 minutos.

\begin{tabular}{|c|c|c|c|c|}
\hline \multirow[t]{2}{*}{ Plano } & \multicolumn{2}{|c|}{ M1CR - Al - 1,0\% de ACP } & \multicolumn{2}{|c|}{ MCR - Al - 1,9\% de ACP } \\
\hline & $\begin{array}{l}\text { Tamanho de } \\
\text { cristalito }(\mathrm{nm})\end{array}$ & $\begin{array}{c}\text { Microdeformação } \\
(\%)\end{array}$ & $\begin{array}{l}\text { Tamanho de } \\
\text { cristalito(nm) }\end{array}$ & $\begin{array}{c}\text { Microdeformação } \\
(\%)\end{array}$ \\
\hline 111 & 72,1 & 0,049 & 75,9 & 0,043 \\
\hline 200 & 95,4 & 0,044 & 95,6 & 0,054 \\
\hline 220 & 76,5 & 0,048 & 76,7 & 0,046 \\
\hline 311 & 65,4 & 0,047 & 75,2 & 0,049 \\
\hline 222 & 72,1 & 0,049 & 75,9 & 0,043 \\
\hline 400 & 95,4 & 0,044 & 95,6 & 0,054 \\
\hline 331 & 76,9 & 0,049 & 63,8 & 0,045 \\
\hline 420 & 63,0 & 0,047 & 63,2 & 0,049 \\
\hline Média & 77 & 0,047 & 78 & 0,048 \\
\hline $\begin{array}{l}\text { Desvio } \\
\text { Padrão }\end{array}$ & 12 & 0,002 & 12 & 0,005 \\
\hline $\begin{array}{l}\text { Parâmetro } \\
\text { de rede }\end{array}$ & \multicolumn{2}{|c|}{$4,0495 \pm 0,0001$} & \multicolumn{2}{|c|}{$4,04941 \pm 0,00004$} \\
\hline $\mathrm{R}_{\mathrm{wp}}(\%)$ & \multicolumn{2}{|r|}{8,81} & \multicolumn{2}{|r|}{8,52} \\
\hline $\begin{array}{l}\text { Qualidade } \\
\text { de ajuste }\end{array}$ & \multicolumn{2}{|c|}{1,238} & \multicolumn{2}{|c|}{1,257} \\
\hline
\end{tabular}

TABELA 19 -Tamanho de cristalito, microdeformação e parâmetro de rede do alumínio em misturas tipo com 1,0\%(M1CR) e 1,9\%(MCR) de ACP, após moagem de 120 minutos.

\begin{tabular}{|c|c|c|c|c|}
\hline \multirow{2}{*}{ Plano } & \multicolumn{2}{|c|}{ M1CR - Al - 1,0 \% de ACP } & \multicolumn{2}{c|}{ MCR - Al - 1,9\% de ACP } \\
\cline { 2 - 5 } & $\begin{array}{c}\text { Tamanho de } \\
\text { cristalito(nm) }\end{array}$ & $\begin{array}{c}\text { Microdeformação } \\
(\%)\end{array}$ & $\begin{array}{c}\text { Tamanho de } \\
\text { cristalito(nm) }\end{array}$ & $\begin{array}{c}\text { Microdeformação } \\
(\%)\end{array}$ \\
\hline 111 & 99,5 & 0,164 & 104,6 & 0,151 \\
\hline 200 & 31,4 & 0,132 & 32,6 & 0,149 \\
\hline 220 & 30,4 & 0,157 & 31,6 & 0,150 \\
\hline 311 & 22,5 & 0,148 & 23,6 & 0,150 \\
\hline 222 & 99,5 & 0,164 & 104,6 & 0,151 \\
\hline 400 & 31,4 & 0,132 & 32,6 & 0,149 \\
\hline 331 & 17,6 & 0,159 & 16,7 & 0,151 \\
\hline 420 & 14,9 & 0,148 & 12,6 & 0,150 \\
\hline Média & $\mathbf{4 3}$ & $\mathbf{0 , 1 5 1}$ & $\mathbf{4 5}$ & $\mathbf{0 , 1 5 0}$ \\
\hline $\begin{array}{c}\text { Desvio } \\
\text { Padrão }\end{array}$ & $\mathbf{3 5}$ & $\mathbf{0 , 0 1 3}$ & $\mathbf{3 8}$ & $\mathbf{0 , 0 0 1}$ \\
\hline $\begin{array}{c}\text { Parâmetro } \\
\text { de rede }\end{array}$ & $\mathbf{4 , 0 4 7 8} \mathbf{0 , 0 0 0 1}$ & $\mathbf{4 , 0 4 8 6} \pm \mathbf{0 , 0 0 0 1}$ \\
\hline Rwp (\%) & \multicolumn{3}{|c|}{$\mathbf{7 , 9 5}$} & \multicolumn{3}{c|}{$\mathbf{7 , 5 0}$} \\
\hline $\begin{array}{c}\text { Qualidade } \\
\text { de ajuste }\end{array}$ & \multicolumn{2}{|c|}{$\mathbf{1 , 1 9 7}$} & $\mathbf{1 , 2 7 2}$ \\
\hline
\end{tabular}


TABELA 20 -Tamanho de cristalito, microdeformação e parâmetro de rede do nióbio em misturas moídas com 1,0\%(M1CR) e 1,9\%(MCR) de ACP, após moagem de 20 minutos.

\begin{tabular}{|c|c|c|c|c|}
\hline \multirow[t]{2}{*}{ Plano } & \multicolumn{2}{|c|}{ M1CR - Nb - 1,0\% de ACP } & \multicolumn{2}{|c|}{ MCR $-\mathrm{Nb}-1,9 \%$ de ACP } \\
\hline & $\begin{array}{l}\text { Tamanho de } \\
\text { cristalito }(\mathrm{nm})\end{array}$ & $\begin{array}{c}\text { Microdeformação } \\
(\%)\end{array}$ & $\begin{array}{l}\text { Tamanho de } \\
\text { cristalito(nm) }\end{array}$ & $\begin{array}{c}\text { Microdeformação } \\
(\%)\end{array}$ \\
\hline 110 & 37,0 & 0,258 & 37,5 & 0,267 \\
\hline 200 & 32,1 & 0,215 & 33,4 & 0,206 \\
\hline 211 & 20,4 & 0,258 & 21,8 & 0,267 \\
\hline 220 & 37,0 & 0,258 & 37,5 & 0,267 \\
\hline 310 & 20,0 & 0,231 & 19,7 & 0,230 \\
\hline 222 & 19,2 & 0,271 & 18,6 & 0,284 \\
\hline Média & 28 & 0,248 & 28 & 0,253 \\
\hline $\begin{array}{l}\text { Desvio } \\
\text { Padrão }\end{array}$ & 9 & 0,021 & 9 & 0,030 \\
\hline $\begin{array}{l}\text { Parâmetro } \\
\text { de rede }\end{array}$ & \multicolumn{2}{|c|}{$3,3063 \pm 0,0001$} & \multicolumn{2}{|c|}{$3,30706 \pm 0,00005$} \\
\hline $\mathrm{R}_{\mathrm{wp}}(\%)$ & \multicolumn{2}{|c|}{8,81} & \multicolumn{2}{|r|}{8,52} \\
\hline $\begin{array}{l}\text { Qualidade } \\
\text { de ajuste }\end{array}$ & \multicolumn{2}{|c|}{1,238} & \multicolumn{2}{|c|}{1,257} \\
\hline
\end{tabular}

TABELA 21 -Tamanho de cristalito, microdeformação e parâmetro de rede do nióbio em misturas moídas com 1,0\%(M1CR) e 1,9\%(MCR) de ACP, após moagem de 120 minutos.

\begin{tabular}{|c|c|c|c|c|}
\hline \multirow[t]{2}{*}{ Plano } & \multicolumn{2}{|c|}{ M1CR - Nb - 1,0\% de ACP } & \multicolumn{2}{|c|}{ MCR - Nb $-1,9 \%$ de ACP } \\
\hline & $\begin{array}{l}\text { Tamanho de } \\
\text { cristalito }(\mathrm{nm})\end{array}$ & $\begin{array}{c}\text { Microdeformação } \\
(\%)\end{array}$ & $\begin{array}{l}\text { Tamanho de } \\
\text { cristalito(nm) }\end{array}$ & $\begin{array}{c}\text { Microdeformação } \\
(\%)\end{array}$ \\
\hline 110 & 24,8 & 0,356 & 32,8 & 0,353 \\
\hline 200 & 25,9 & 0,342 & 38,8 & 0,351 \\
\hline 211 & 16,1 & 0,356 & 20,7 & 0,353 \\
\hline 220 & 24,8 & 0,356 & 32,8 & 0,353 \\
\hline 310 & 15,7 & 0,347 & 19,0 & 0,352 \\
\hline 222 & 11,1 & 0,360 & 13,5 & 0,353 \\
\hline Média & 20 & 0,353 & 26 & 0,352 \\
\hline $\begin{array}{l}\text { Desvio } \\
\text { Padrão }\end{array}$ & 6 & 0,007 & 10 & 0,001 \\
\hline $\begin{array}{l}\text { Parâmetro } \\
\text { de rede }\end{array}$ & \multicolumn{2}{|c|}{$3,3098 \pm 0,0001$} & \multicolumn{2}{|c|}{$3,3116 \pm 0,0001$} \\
\hline $\mathrm{R}_{\mathrm{wp}}(\%)$ & \multicolumn{2}{|r|}{7,95} & \multicolumn{2}{|r|}{7,50} \\
\hline $\begin{array}{l}\text { Qualidade } \\
\text { de ajuste }\end{array}$ & \multicolumn{2}{|r|}{1,197} & \multicolumn{2}{|c|}{1,272} \\
\hline
\end{tabular}


TABELA 22 -Tamanho de cristalito, microdeformação e parâmetro de rede da fase $\mathrm{Nb}(\mathrm{H})$, em misturas moídas com 1,0\%(M1CR) e 1,9\%(MCR) de ACP, após moagem de 120 minutos.

\begin{tabular}{|c|c|c|c|c|}
\hline & \multicolumn{2}{|c|}{$\mathrm{M} 1 \mathrm{CR}-\mathrm{Nb}(\mathrm{H})-1,0 \%$ de ACP } & \multicolumn{2}{|c|}{$\mathrm{MCR}-\mathrm{Nb}(\mathrm{H})-1,9 \%$ de ACP } \\
\hline & $\begin{array}{l}\text { Tamanho de } \\
\text { cristalito(nm) }\end{array}$ & $\begin{array}{c}\text { Microdeformação } \\
(\%)\end{array}$ & $\begin{array}{l}\text { Tamanho de } \\
\text { cristalito(nm) }\end{array}$ & $\begin{array}{c}\text { Microdeformação } \\
(\%)\end{array}$ \\
\hline $\begin{array}{l}\text { Valor } \\
\text { médio }\end{array}$ & 7,1 & 1,112 & 17 & 1,942 \\
\hline $\begin{array}{l}\text { Fração } \\
\text { Vol. (\%) }\end{array}$ & \multicolumn{2}{|c|}{$2,5 \pm 1,5$} & \multicolumn{2}{|c|}{$4,0 \pm 1$} \\
\hline $\begin{array}{l}\text { Parâmetro } \\
\text { de rede }\end{array}$ & \multicolumn{2}{|c|}{$3,3402 \pm 0,0011$} & \multicolumn{2}{|c|}{$3,3636 \pm 0,0007$} \\
\hline $\mathrm{R}_{\mathrm{wp}}(\%)$ & \multicolumn{2}{|r|}{7,95} & \multicolumn{2}{|r|}{7,50} \\
\hline $\begin{array}{l}\text { Qualidade } \\
\text { de ajuste }\end{array}$ & \multicolumn{2}{|c|}{1,197} & \multicolumn{2}{|c|}{1,272} \\
\hline
\end{tabular}

Os valores de tamanho de cristalito e parâmetro de rede da fase $\mathrm{Nb}(\mathrm{H})$, para 1\% de ACP (TAB.22), são semelhantes aos obtidos para o nióbio pré-ativado (TAB.6 - p.69), entretanto, a microdeformação foi significativamente maior. $O$ aumento da quantidade de ACP para $1,9 \%$, elevou a microdeformação e o parâmetro de rede da fase $\mathrm{Nb}(\mathrm{H})$ o que pode ser explicado pela maior oferta de hidrogênio. $A$ análise da fase $\mathrm{Nb}(\mathrm{H})$ não pode ser conclusiva, devido à baixa fração volumétrica e a sobreposição com os picos de nióbio. Entretanto, os resultados obtidos indicam uma possível relação entre a quantidade de ACP utilizada e o parâmetro de rede da fase $\mathrm{Nb}(\mathrm{H})$. Esse aumento do parâmetro de rede pode estar acompanhado do aumento da densidade de defeitos cristalinos. Aventar esta possibilidade se baseia na forma dos picos sobrepostos, cujo refinamento mostrou que a fase $\mathrm{Nb}(\mathrm{H})$ contribui na forma final com picos com grande alargamento. Portanto, os valores de tamanho de cristalito $\mathrm{e}$ microdeformação, apresentados na TAB.22, são apenas qualitativos.

Os resultados apresentados nas TAB.18 a 21 mostram que o ACP, nas quantidades utilizadas, exerce pouco efeito sobre a microdeformação e o tamanho de cristalito, tanto do nióbio quanto do alumínio. Comparando esses resultados com os apresentados nas TAB.5 e 6, observa-se que a moagem da mistura $\mathrm{Nb}_{25} \mathrm{Al}_{75}$ por 120 minutos nas condições utilizadas, confere ao alumínio tamanhos de cristalito e grau de microdeformação semelhantes aos obtidos após 
50 horas de moagem apenas de alumínio, em moinho do tipo planetário. Já no caso do nióbio, embora o material pré-ativado apresente um tamanho de cristalito menor e uma microdeformação maior, 120 minutos de moagem conjunta com o alumínio, em moinho tipo Spex®, proporciona um aumento da densidade de defeitos cristalinos significativa.

\subsubsection{PERFIS DE TEMPERATURA}

A FIG.42 apresenta a reprodutibilidade dos perfis de temperatura para misturas com 1\% de ACP (M1CR), após 20 e 120 minutos de moagem, e também os resultados apresentados no item 5.2.3, referentes as misturas com $1,9 \%$ de ACP (MCR) . A TAB.23 apresenta os resultados da análise desses perfis.
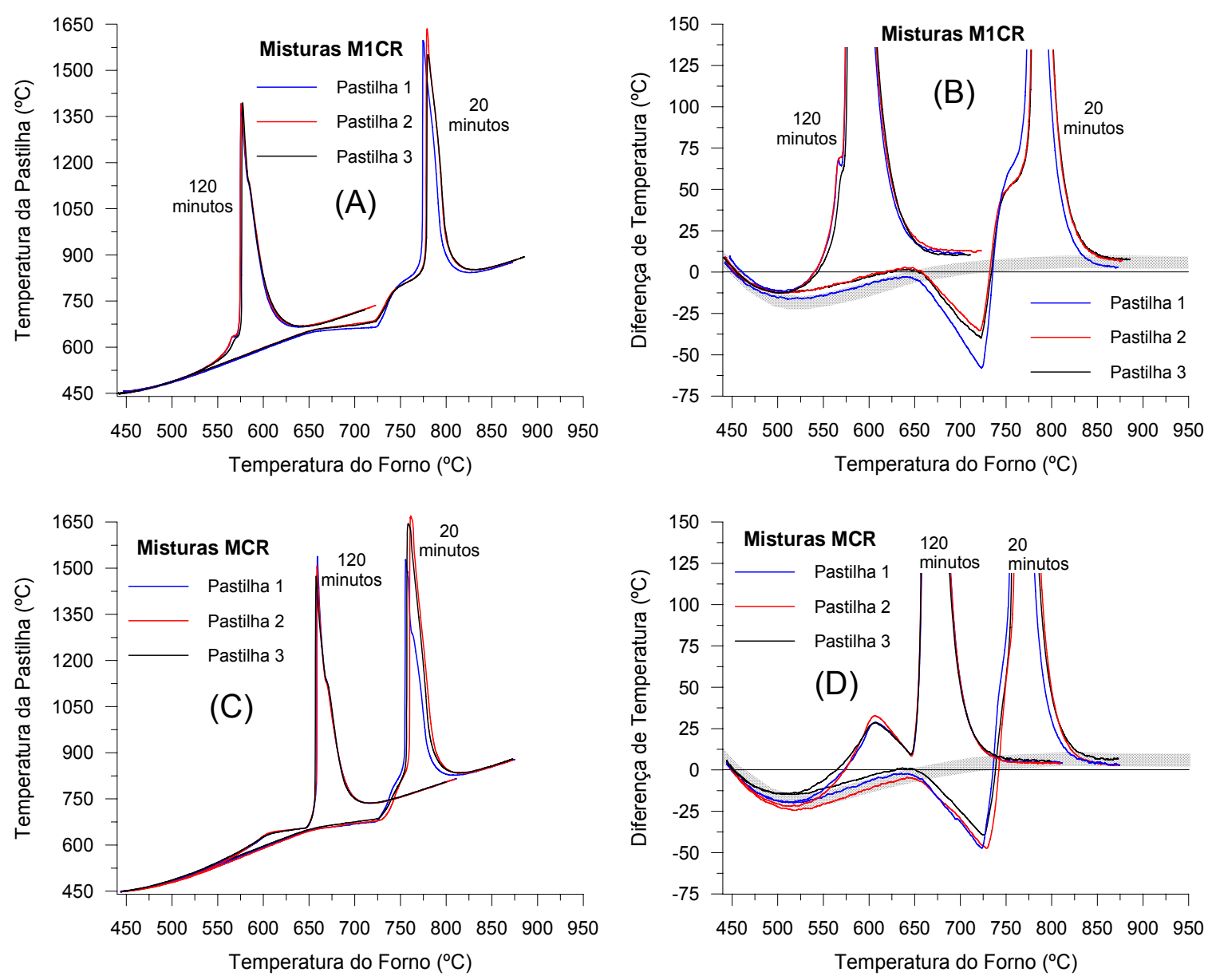

FIGURA 42 - Perfis de temperatura e de diferença de temperatura entre pastilha e forno, referentes às pastilhas preparadas a partir de misturas de reagentes como recebidos, moidas com 1\% de ACP, M1CR (A e B) e 1,9\% de ACP, MCR (C e D). Tempos de moagem de 20 e 120 minutos. 
TABELA 23 -Valores característicos do perfil de temperatura para pastilhas preparadas a partir de misturas de reagentes como recebidos, moidas com $1 \%$ de ACP (M1CR) e 1,9\% de ACP (MCR). Tempos de moagem de 20 e 120 minutos.

\begin{tabular}{|c|c|c|c|c|}
\hline & $\begin{array}{c}\text { M1CR } \\
20 \text { minutos }\end{array}$ & $\begin{array}{c}\text { MCR } \\
20 \text { minutos }\end{array}$ & $\begin{array}{c}\text { M1CR } \\
120 \text { minutos }\end{array}$ & $\begin{array}{c}\text { MCR } \\
120 \text { minutos }\end{array}$ \\
\hline $\begin{array}{c}\text { Temperatura } \\
\text { de ignição }\left({ }^{\circ} \mathrm{C}\right)\end{array}$ & $847 \pm 8$ & $681 \pm 5$ & $541 \pm 3$ & $659 \pm 1$ \\
\hline $\begin{array}{c}\text { Temperatura de } \\
\text { explosão térmica }\left({ }^{\circ} \mathrm{C}\right)\end{array}$ & $969 \pm 11$ & $935 \pm 15$ & $740 \pm 23$ & $813 \pm 31$ \\
\hline $\begin{array}{l}\text { Temperatura de } \\
\text { Combustão }\left({ }^{\circ} \mathrm{C}\right) \\
\end{array}$ & $1595 \pm 43$ & $1615 \pm 76$ & $1393 \pm 1$ & $1507 \pm 32$ \\
\hline$\Delta \mathrm{T}\left({ }^{\circ} \mathrm{C}\right)$ & $747 \pm 42$ & $933 \pm 73$ & $852 \pm 2$ & $847 \pm 32$ \\
\hline $\begin{array}{l}\text { Taxa de aquecimento } \\
\text { máxima }\left({ }^{\circ} \mathrm{C} / \mathrm{s}\right)\end{array}$ & $802 \pm 68$ & $1110 \pm 122$ & $626 \pm 38$ & $1283 \pm 262$ \\
\hline Tempo de reação (s) & $19 \pm 2$ & $86 \pm 2$ & $75 \pm 6$ & $24 \pm 2$ \\
\hline $\begin{array}{c}\text { Taxa de aquecimento } \\
\text { média }\left({ }^{\circ} \mathrm{C} / \mathrm{s}\right)\end{array}$ & $40 \pm 5$ & $11 \pm 1$ & $11 \pm 1$ & $36 \pm 2$ \\
\hline $\begin{array}{l}\text { Tempo de fusão do } \\
\text { alumínio (s) }\end{array}$ & $208 \pm 5$ & $208 \pm 9$ & $11 \pm 1$ & $101 \pm 1$ \\
\hline
\end{tabular}

O tempo de moagem produziu um efeito intenso no comportamento térmico da reação da mistura com $1 \%$ de ACP. A temperatura de ignição da mistura com 120 minutos de moagem foi $300^{\circ} \mathrm{C}$ menor que a constatada na mistura moída por 20 minutos. A redução na quantidade de ACP aumentou o rendimento de formação de agregados (FIG.40C - p.111), formando uma microestrutura lamelar mais fina. Essa redução na espessura das lamelas aumentou a área de interface Al-Nb, potencializando a formação de $\mathrm{NbAl}_{3}$ por difusão no estado sólido. Esse processo foi tão intenso que disparou a reação provavelmente sem a presença de fase líquida. Os valores de taxa de aquecimento média e máxima foram relativamente baixos indicando que o $\mathrm{NbAl}_{3}$ formado por difusão consumiu parte dos reagentes diminuindo o calor liberado durante a reação.

A moagem de misturas com $1,9 \%$ de ACP (MCR) mostrou que a quantidade de ácido esteárico tem um efeito muito significativo sobre o perfil de temperatura da pastilha, aumentando a cinética de reação e também a temperatura máxima de reação. $\mathrm{O}$ aquecimento da pastilha no estágio pré-fusão nas misturas moídas por 120 minutos foi menos intenso que o verificado na mistura com $1 \%$, indicando uma formação de $\mathrm{NbAl}_{3}$ por difusão menor na mistura MCR. 


\subsubsection{MICROESTRUTURA DAS PASTILHAS}

As micrografias das pastilhas com 1,0\%(M1CR) e 1,9\%(MCR) de ACP estão apresentadas nas FIG.43 e 44. As pastilhas M1CR e MCR reagidas apresentaram uma microestrutura formada por uma matriz cinza claro de $\mathrm{NbAl}_{3}$, partículas brancas ricas em nióbio, partículas cinza-escuras ricas em alumínio. Algumas regiões próximas à superfície, e também a própria superfície apresentaram a formação do eutético $\mathrm{NbAl}_{3}-\mathrm{Nb}_{2} \mathrm{Al}$, indicando que houve um desvio local da estequiometria da mistura, com perda de alumínio. Segundo o diagrama Al-Nb (p.21) a temperatura do eutético é de $1590^{\circ} \mathrm{C}$, o que corrobora com os valores de temperatura máxima de reação registrada nessas pastilhas. A quantidade de óxidos e carbonetos de nióbio e de alumínio foi significativamente menor que a verificada nas pastilhas preparadas a partir de reagentes préativados (item 5.2.4), evidenciando que o grau de decomposição do ACP depende do tempo de moagem.

A distribuição dos reagentes na pastilha, cujo aquecimento foi interrompido, é muito semelhante entre as pastilhas com 1,0\% e 1,9\% de ACP. A forma achatada das partículas obtida após 20 minutos de moagem produziu uma distribuição lamelar grosseira do nióbio. A quantidade de $\mathrm{NbAl}_{3}$ formada antes da temperatura de ignição é significativamente maior na pastilha com $1 \%$ de ACP. Isto mostra que a quantidade maior de ACP junto às interfaces $\mathrm{Al}-\mathrm{Nb}$, no caso da mistura com $1,9 \%$, atuou como uma barreira no processo de formação de $\mathrm{NbAl}_{3}$.

A análise da microestrutura das pastilhas M1CR e MCR reagidas revelou um aumento da quantidade de óxidos e carbonetos e a presença de uma pequena fração de alumínio não reagido. A ausência do eutético e a presença de alumínio não reagido indicam um desvio da estequiometria da mistura oposto ao verificado nas pastilhas de misturas com 20 minutos de moagem, ou seja, houve falta de nióbio para completar a reação. Essa deficiência de nióbio pode estar associada à precipitação mais intensa de carbonetos de nióbio. 


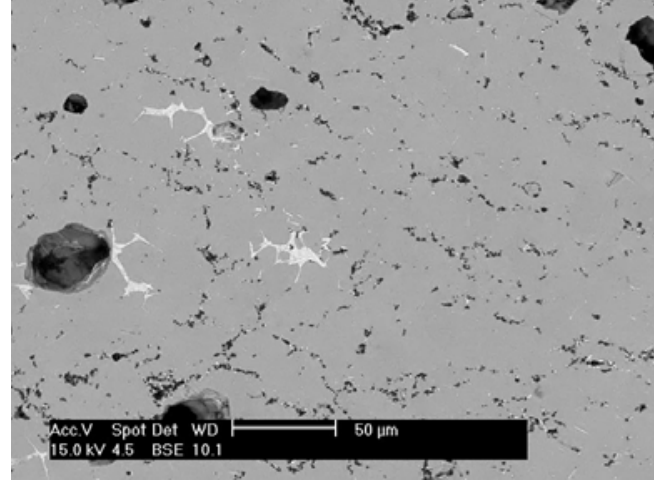

(A) $\mathrm{M} 1 \mathrm{CR}-1,0 \%$ reagida

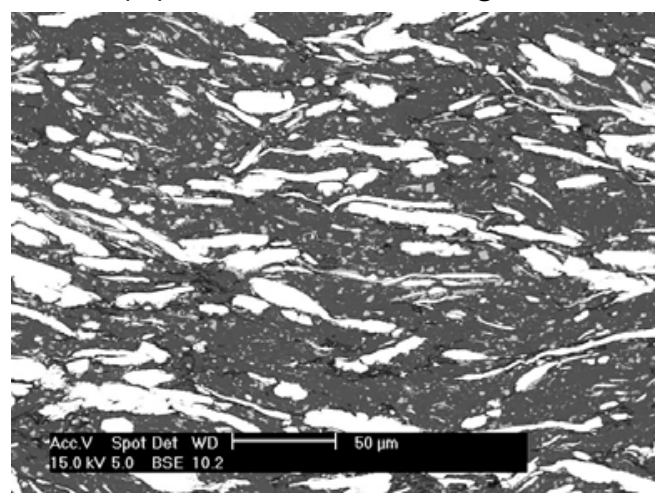

(C) M1CR - 1,0\% antes da reação

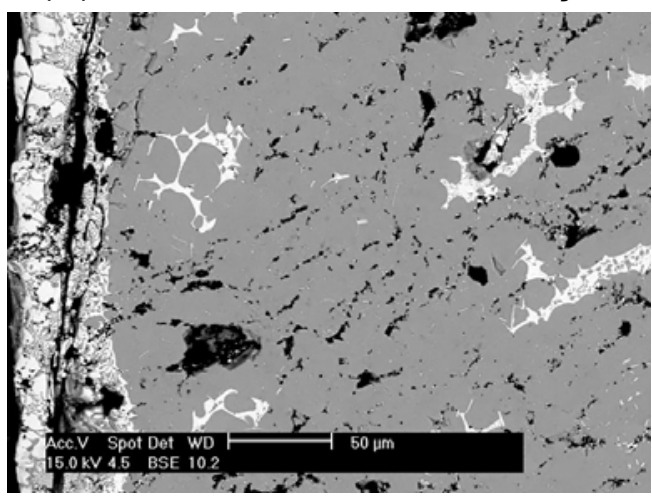

(E) MCR $-1,9 \%$ reagida

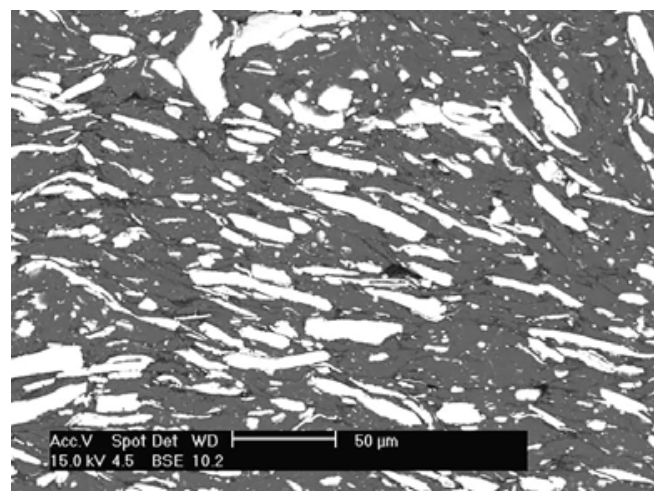

(G) MCR - 1,9\% antes da reação

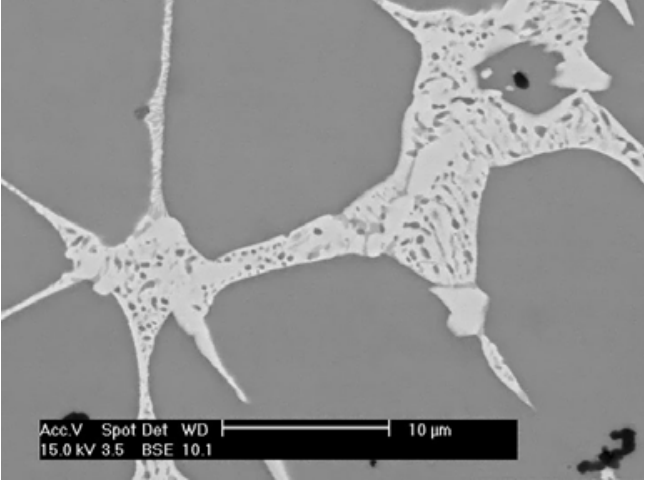

(B) $\mathrm{M} 1 \mathrm{CR}-1,0 \%$ reagida

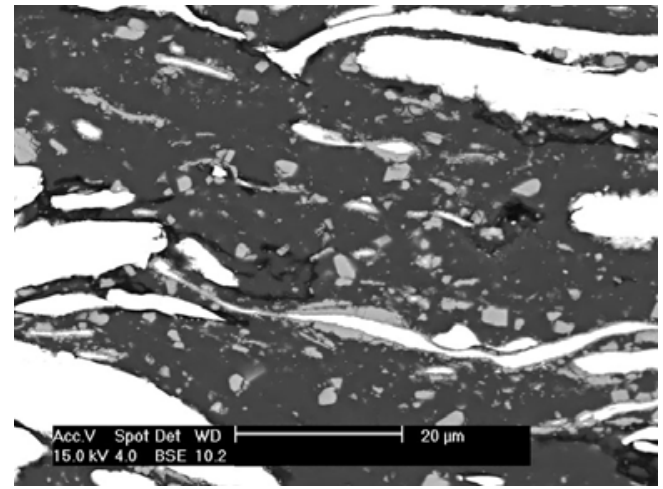

(D) M1CR - 1,0\% antes da reação

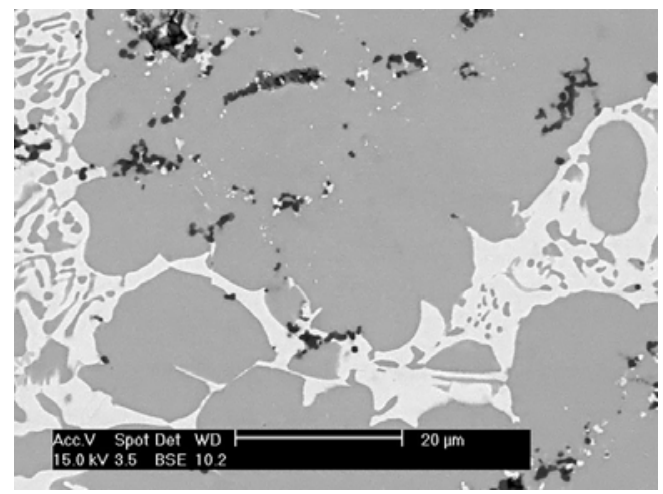

(F) MCR $-1,9 \%$ reagida

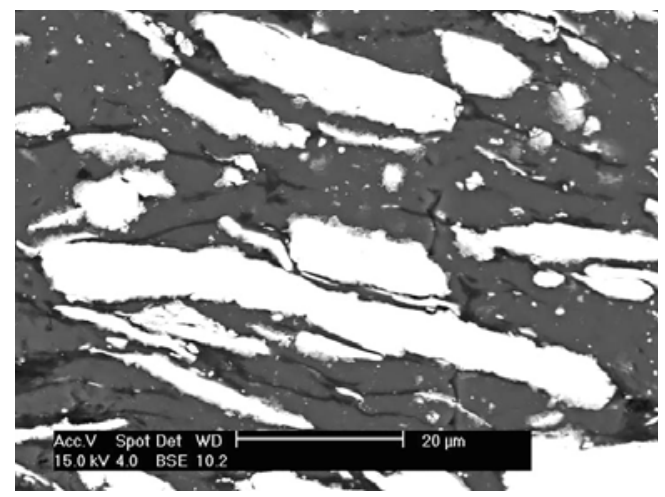

(H) MCR - 1,9\% antes da reação

FIGURA 43 - Micrografias de pastilhas reagidas e de pastilhas com interrupção de aquecimento antes da ignição referente às misturas com $1,0 \%$ (M1CR) e 1,9\% (MCR) de ACP, com 20 minutos de moagem. Microscopia eletrônica de varredura com imagem de elétrons retroespalhados. 


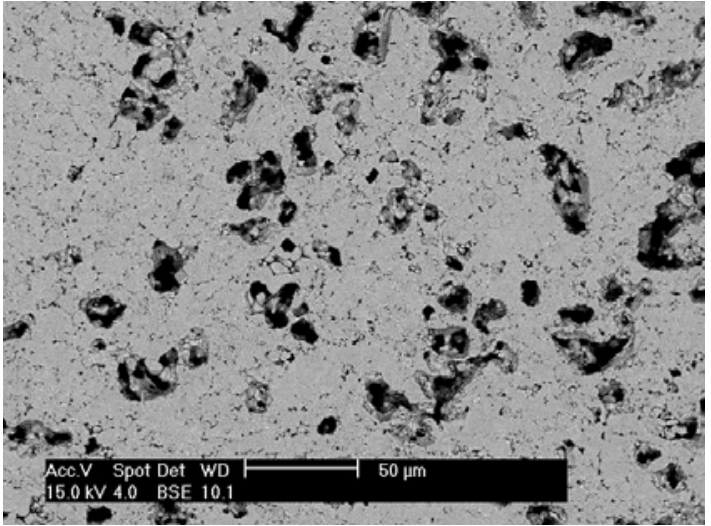

(A) $\mathrm{M} 1 \mathrm{CR}-1,0 \%$ reagida

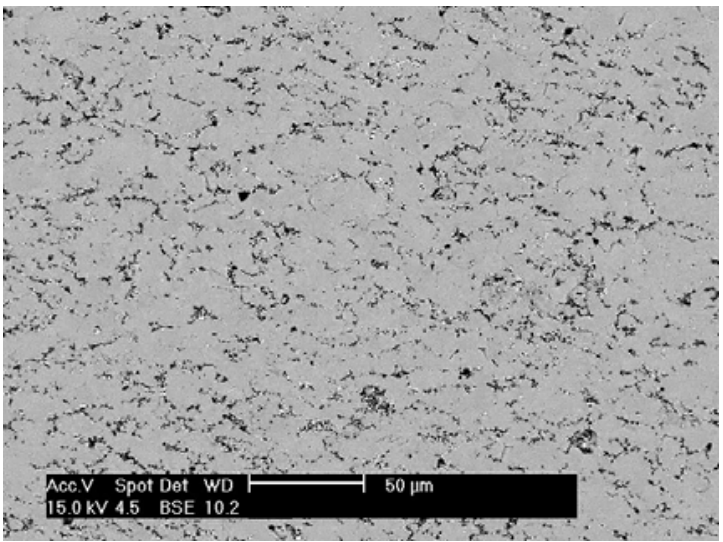

(E) MCR - $1,9 \%$ reagida

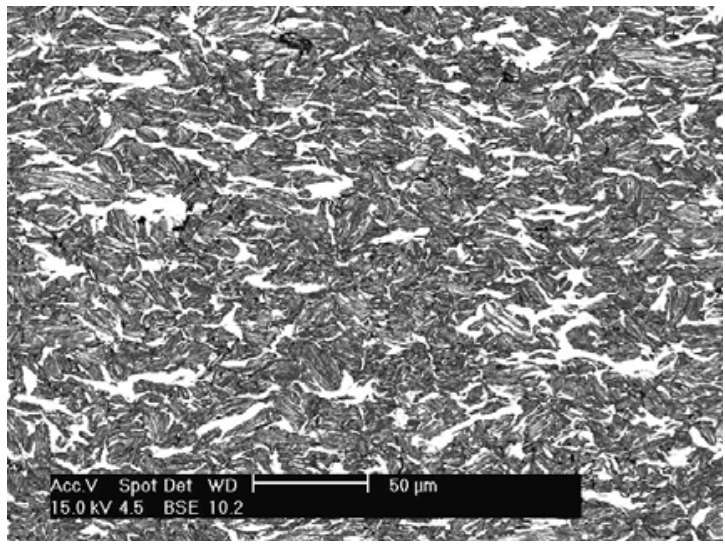

(G) MCR - 1,9\% antes da reação

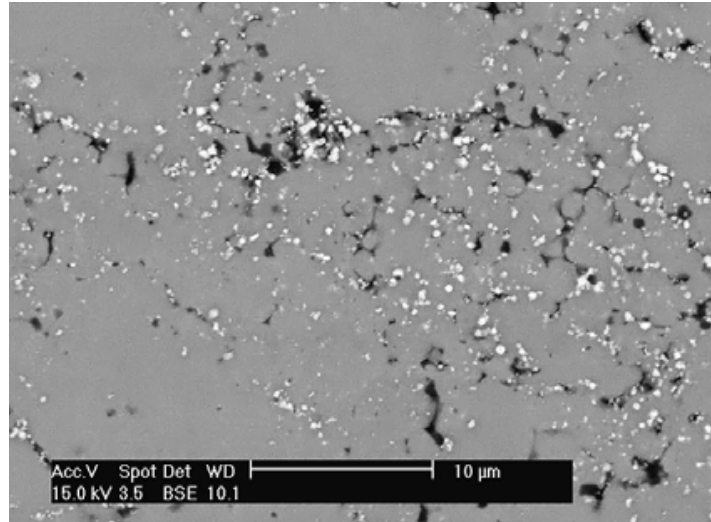

(B) $\mathrm{M} 1 \mathrm{CR}-1,0 \%$ reagida

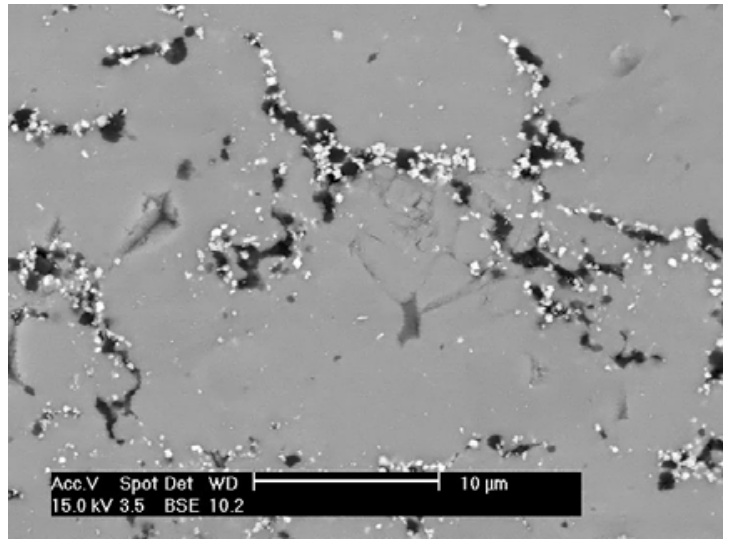

(F) MCR - 1,9\% reagida

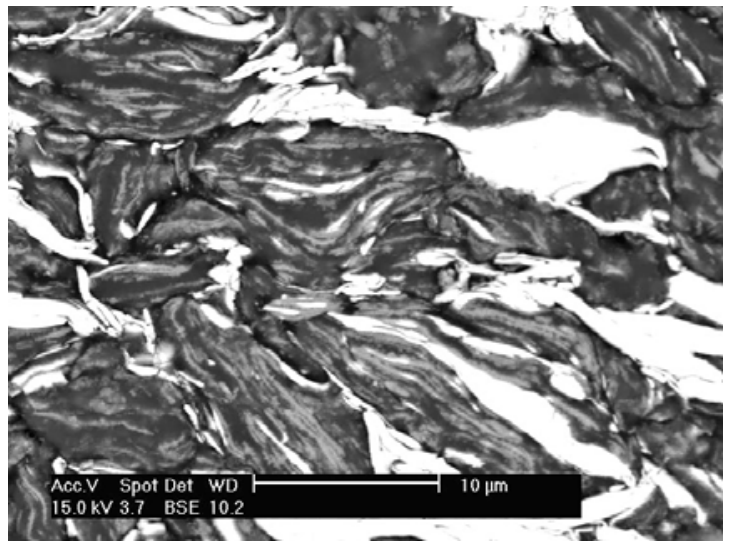

(H) MCR - 1,9\% antes da reação

FIGURA 44 - Micrografias das pastilhas reagidas referente às misturas com 1,0\% (M1CR) e 1,9\% (MCR) de ACP e da pastilha com interrupção de aquecimento antes da ignição referente à mistura com $1,9 \%$ de ACP, todas as misturas com 120 minutos de moagem. Microscopia eletrônica de varredura com imagem de elétrons retroespalhados. 


\section{DISCUSSÃO}

Os resultados apresentados no item 5 deste trabalho fornecem uma grande quantidade de detalhes relativos à microestrutura e comportamento térmico das misturas, com e sem moagem com alta energia. Nessa discussão serão ressaltados os resultados que mostram qual é a significância da densidade de defeitos cristalinos e da área de interface ente o alumínio e o nióbio no processo de síntese por combustão simultânea, questionamento principal apresentado no objetivo deste trabalho.

A reação de combustão de misturas simples (misturas homogeneizadas sem ativação mecânica simultânea) mostrou, de maneira geral, o efeito já conhecido da diminuição do tamanho de partícula no aumento da cinética de reação. Entretanto, alguns resultados microestruturais, como a formação de carbonetos de alumínio antes da reação de combustão em misturas pré-ativadas, são informações importantes na análise do comportamento térmico da reação. Uma das misturas, preparada somente com o alumínio no estado pré-ativado (SPA-A), apresentou uma redução de $50 \%$ na taxa de aquecimento máxima durante a reação, em relação à mistura simples preparada com alumínio como recebido. Isto aconteceu provavelmente em razão da presença de carbonetos de alumínio no alumínio líquido.

O procedimento de pré-ativação mecânica dos reagentes foi uma das estratégias principais deste trabalho. $\mathrm{O}$ aumento da resistência mecânica dos reagentes, provocado pela deformação plástica, modificou a distribuição das partículas de nióbio na matriz de alumínio, durante a moagem da mistura, provocando comportamentos térmicos diferenciados.

A moagem com alta energia se mostrou muito eficiente no processo de homogeneização da dispersão dos reagentes. Entretanto, este procedimento de tem limitações intrínsecas, no caso da aplicação em misturas dúcteis. O uso de agentes controladores de processo é, geralmente, indispensável na moagem de misturas dúcteis, sendo que sua interação com os reagentes pode afetar os processos posteriores. Um exemplo desse efeito foi a precipitação carboneto de alumínio durante o aquecimento do alumínio pré-ativado, cujo processo utilizou 
ácido esteárico como ACP. A presença desses carbonetos afetou a cinética da reação por combustão.

A seguir serão realizadas algumas discussões mais específicas sobre os resultados experimentais, com o objetivo de destacar os mais significantes e, também, fundamentar as principais conclusões do trabalho.

\section{PRIMEIRO CONJUNTO DE EXPERIMENTOS}

Um dos objetivos do primeiro conjunto de experimentos foi verificar qual o efeito da densidade de defeitos cristalinos sobre a reação de combustão simultânea. A estratégia definida foi a comparação do comportamento térmico de misturas simples em duas condições iniciais distintas quanto a densidade de defeitos cristalinos, são elas a SPA (alta densidade) e SPA-R (baixa densidade) mantendo-se a distribuição de tamanho de partícula.

A FIG.45 apresenta uma comparação do comportamento térmico das misturas simples. A diferença de distribuição granulométrica do nióbio, entre as condições pré-ativada e como recebida, foi a principal variável que determinou o comportamento térmico das pastilhas. A comparação das misturas simples de reagentes como recebidos (SCR - nióbio mais grosso) e de reagentes préativados e recozidos (SPA- $R$ - nióbio mais fino), ambas com baixa densidade de defeitos cristalinos, mostra que a redução do tamanho médio de partícula do nióbio acelera a reação, reduzindo a temperatura de ignição e aumentando a taxa de aquecimento máxima. Esses dados estão reapresentados na TAB.24, na próxima página.

As misturas SPA e SPA-R apresentaram temperaturas de ignição e taxas de aquecimento máxima muito semelhantes. Nesse caso, pode-se afirmar que a densidade de defeitos cristalinos, introduzidos pela pré-ativação, não produziu efeito sobre esses parâmetros. Entretanto, é importante ponderar que não foi possível avaliar a real densidade de defeitos cristalinos no nióbio à temperatura de ignição (não é o caso do alumínio, pois o mesmo está fundido à temperatura de ignição). Popova et al. (2006) mostraram que, em torno de $700^{\circ} \mathrm{C}$, o nióbio encruado inicia um processo de recristalização, porém, não foram apresentados dados sobre a cinética desse processo. Portanto, há uma possibilidade de que 0 

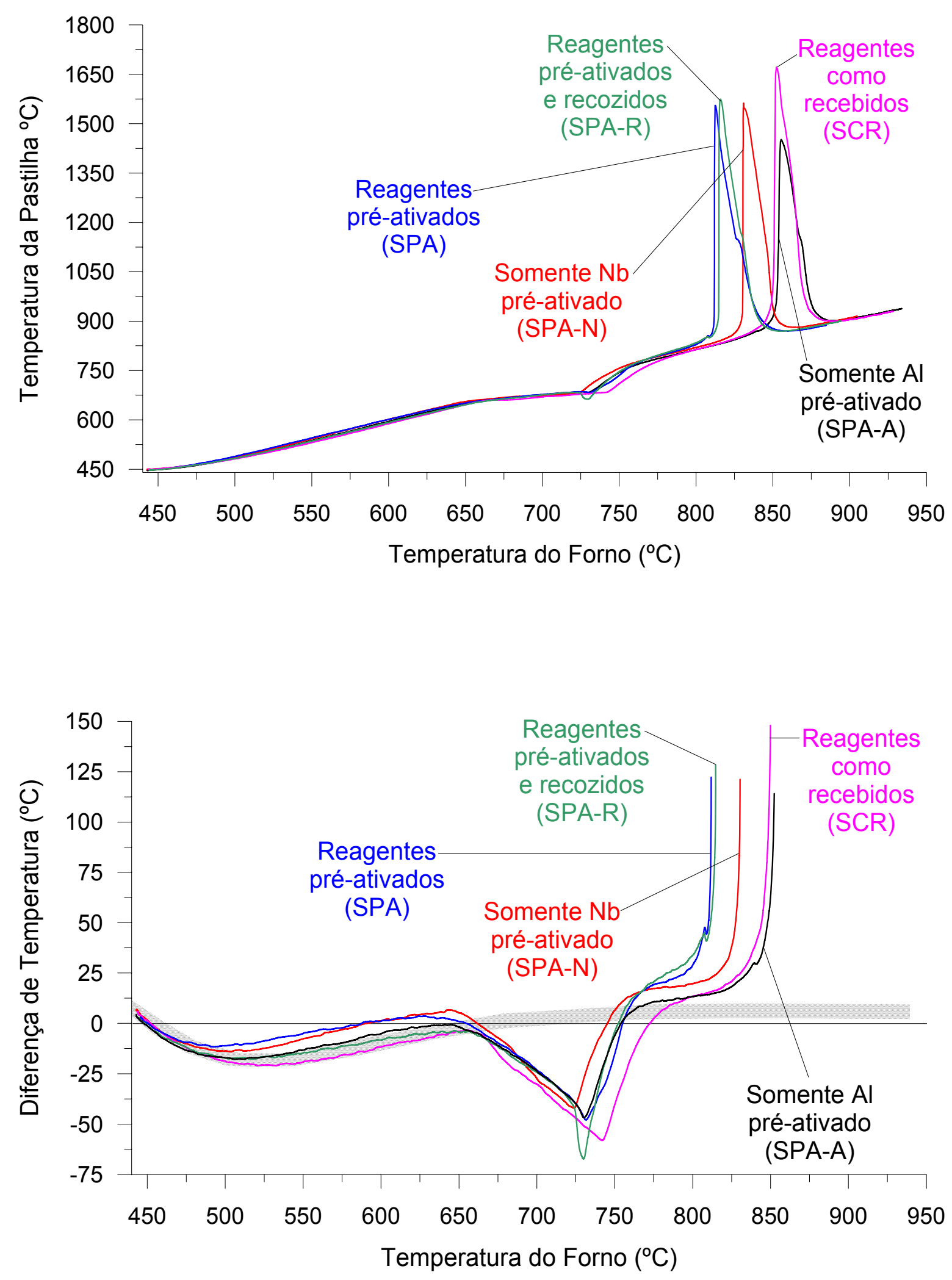

FIGURA 45 - Comparação dos perfis de temperatura e de diferença de temperatura entre pastilha e forno, referentes às pastilhas preparadas a partir de misturas simples. 
TABELA 24 -Valores característicos dos perfis de temperatura para pastilhas preparadas a partir de misturas simples.

\begin{tabular}{|c|c|c|c|c|c|}
\hline & SCR & SPA & SPA-R & SPA-A & SPA-N \\
\hline $\begin{array}{c}\text { Temperatura } \\
\text { de ignição }\left({ }^{\circ} \mathrm{C}\right)\end{array}$ & $878 \pm 4$ & $839 \pm 4$ & $846 \pm 6$ & $875 \pm 3$ & $856 \pm 4$ \\
\hline $\begin{array}{c}\text { Temperatura de } \\
\text { explosão térmica }\left({ }^{\circ} \mathrm{C}\right)\end{array}$ & $1071 \pm 24$ & $907 \pm 9$ & $914 \pm 13$ & $990 \pm 11$ & $952 \pm 22$ \\
\hline $\begin{array}{l}\text { Temperatura de } \\
\text { Combustão }\left({ }^{\circ} \mathrm{C}\right)\end{array}$ & $1648 \pm 22$ & $1509 \pm 41$ & $1582 \pm 37$ & $1451 \pm 6$ & $1560 \pm 56$ \\
\hline$\Delta \mathrm{T}\left({ }^{\circ} \mathrm{C}\right)$ & $770 \pm 25$ & $669 \pm 40$ & $736 \pm 40$ & $577 \pm 8$ & $704 \pm 58$ \\
\hline $\begin{array}{l}\text { Taxa de aquecimento } \\
\text { máxima }\left({ }^{\circ} \mathrm{C} / \mathrm{s}\right)\end{array}$ & $330 \pm 38$ & $\underline{1224 \pm 207}$ & $\underline{1270 \pm 260}$ & $156 \pm 12$ & $1748 \pm 294$ \\
\hline Tempo de reação (s) & $35 \pm 5$ & $22 \pm 3$ & $16 \pm 2$ & $39 \pm 3$ & $29 \pm 2$ \\
\hline $\begin{array}{c}\text { Taxa de aquecimento } \\
\text { média }\left({ }^{\circ} \mathrm{C} / \mathrm{s}\right)\end{array}$ & $23 \pm 3$ & $31 \pm 5$ & $46 \pm 2$ & $15 \pm 1$ & $24 \pm 3$ \\
\hline $\begin{array}{l}\text { Tempo de fusão do } \\
\text { alumínio (s) }\end{array}$ & $236 \pm 11$ & $208 \pm 10$ & $215 \pm 8$ & $236 \pm 11$ & $202 \pm 10$ \\
\hline
\end{tabular}

nióbio esteja completamente recristalizado à temperatura de $840^{\circ} \mathrm{C}$, correspondente a ignição. De qualquer forma, a ativação mecânica observada, representada pela temperatura de ignição e pela cinética de reação, está estritamente ligada à redução do tamanho de partícula do nióbio.

As misturas que utilizaram somente um dos reagentes no estado préativado (SPA-A e SPA-N) forneceram informações importantes sobre o efeito da pré-ativação na reação de combustão (mediante comparação com as misturas de reagentes como recebidos). As misturas SCR e SPA-A foram preparadas com o mesmo pó de nióbio, mas com o pó de alumínio em duas condições diferentes, como recebido e pré-ativado, respectivamente. A mistura que utilizou alumínio pré-ativado (SPA-A) apresentou reação incompleta e a taxa de aquecimento máxima foi de $156^{\circ} \mathrm{C} / \mathrm{s}$, inferior à da mistura com alumínio como recebido (SCR), cuja taxa foi de $330^{\circ} \mathrm{C} / \mathrm{s}$. No caso das misturas SPA e SPA-N a situação foi semelhante. A mistura preparada com alumínio pré-ativado (SPA) apresentou uma taxa de aquecimento máxima de $1224^{\circ} \mathrm{C} / \mathrm{s}$ contra $1748^{\circ} \mathrm{C} / \mathrm{s}$ obtido na mistura que utilizou alumínio como recebido (SPA-N). Essas constatações mostram que a pré-ativação de alumínio prejudicou a cinética da reação de combustão. A análise da microestrutura antes e depois da reação de combustão mostrou que as 
pastilhas preparadas com alumínio pré-ativado apresentaram, após a reação de combustão, uma grande quantidade de óxidos e carbonetos. A avaliação da microestrutura, antes da reação, revelou a presença de manchas escuras na matriz de alumínio das pastilhas SPA e SPA-A. A análise de difração de raios $X$ de amostras de alumínio pré-ativado e recozido identificou a presença da fase $\mathrm{Al}_{4} \mathrm{C}_{3}$, formado por difusão no estado sólido do carbono proveniente do $A C P$. Portanto, as manchas escuras verificadas na matriz de alumínio têm grande chance de ser $\mathrm{Al}_{4} \mathrm{C}_{3}$. A presença de uma fase sólida insolúvel dispersa no alumínio líquido pode afetar a cinética de reação, que é dependente da movimentação da fase líquida.

\section{SEGUNDO E TERCEIRO CONJUNTOS DE EXPERIMENTOS}

A ativação mecânica de misturas em moinhos de alta energia produz simultaneamente o aumento da área de interface e da densidade de defeitos cristalinos, além do refino dos componentes da mistura. A estratégia para avaliar o efeito de cada um desses processos foi preparar misturas com diferentes tipos de dispersão dos reagentes.

A FIG.46 apresenta uma comparação do comportamento térmico das misturas com 20 minutos de moagem. Os valores característicos dos perfis de temperatura são reapresentados na TAB.25. No caso da moagem de 20 minutos, o tempo curto de moagem não é suficiente para produzir uma dispersão homogênea dos reagentes. Essa dispersão é afetada pela quantidade de ACP utilizada, sendo que teores mais elevados de ACP dificultam o processo de soldagem a frio, diminuindo o tamanho médio de partícula. A distribuição granulométrica do pó de partida também é um fator importante nas moagens de curta duração. A utilização de reagentes dúcteis e grosseiros proporciona a formação de partículas achatadas ("flakes") maiores, prejudicando a formação de interfaces durante o processo de compactação. A utilização de nióbio pré-ativado nas mistura MPA e MPA-N (tamanho médio de partícula menor e ductilidade menor) produziu uma dispersão mais homogênea dos reagentes, bem como uma maior área de interface, aumentando a cinética da reação e reduzindo a temperatura de ignição. Por outro lado, a utilização de quantidades reduzidas de 

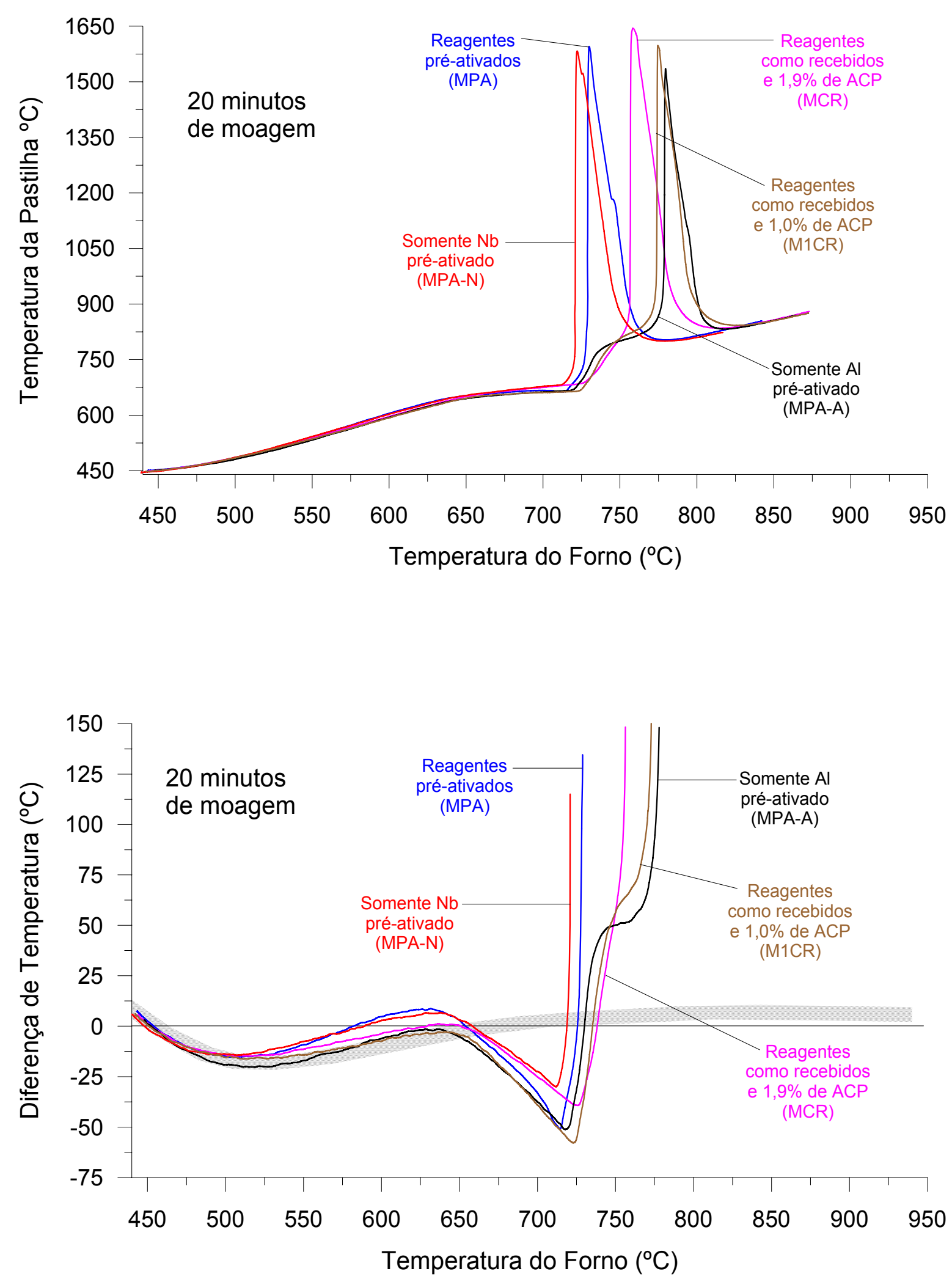

FIGURA 46 - Comparação dos perfis de temperatura e de diferença de temperatura entre pastilha e forno, referentes às pastilhas preparadas a partir de misturas com 20 minutos de moagem. 
TABELA 25 -Valores característicos dos perfis de temperatura para pastilhas preparadas a partir de misturas com 20 minutos de moagem.

\begin{tabular}{|c|c|c|c|c|c|}
\hline & M1CR & MCR & MPA & MPA-A & MPA-N \\
\hline $\begin{array}{c}\text { Temperatura } \\
\text { de ignição }\left({ }^{\circ} \mathrm{C}\right)\end{array}$ & $847 \pm 8$ & $681 \pm 5$ & $668 \pm 5$ & $834 \pm 6$ & $682 \pm 4$ \\
\hline $\begin{array}{c}\text { Temperatura de } \\
\text { explosão térmica }\left({ }^{\circ} \mathrm{C}\right)\end{array}$ & $969 \pm 11$ & $935 \pm 15$ & $874 \pm 10$ & $987 \pm 24$ & $780 \pm 19$ \\
\hline $\begin{array}{c}\text { Temperatura de } \\
\text { Combustão }\left({ }^{\circ} \mathrm{C}\right)\end{array}$ & $1595 \pm 43$ & $1615 \pm 76$ & $1541 \pm 51$ & $1555 \pm 22$ & $1549 \pm 93$ \\
\hline$\Delta \mathrm{T}\left({ }^{\circ} \mathrm{C}\right)$ & $747 \pm 42$ & $933 \pm 73$ & $873 \pm 55$ & $720 \pm 20$ & $867 \pm 91$ \\
\hline $\begin{array}{c}\text { Taxa de aquecimento } \\
\left.\text { máxima ( }{ }^{\circ} \mathrm{C} / \mathrm{s}\right)\end{array}$ & $802 \pm 68$ & $1110 \pm 122$ & $1333 \pm 296$ & $511 \pm 64$ & $1244 \pm 266$ \\
\hline \begin{tabular}{c} 
Tempo de reação (s) \\
\hline $\begin{array}{c}\text { Taxa de aquecimento } \\
\left.\text { média ( }{ }^{\circ} \mathrm{C} / \mathrm{s}\right)\end{array}$
\end{tabular} & $19 \pm 2$ & $86 \pm 2$ & $43 \pm 1$ & $27 \pm 2$ & $23 \pm 2$ \\
\hline $\begin{array}{c}\text { Tempo de fusão do } \\
\text { alumínio (s) }\end{array}$ & $208 \pm 5$ & $208 \pm 9$ & $220 \pm 5$ & $213 \pm 4$ & $213 \pm 3$ \\
\hline
\end{tabular}

ACP (M1CR - 20 minutos) e nióbio como recebido (MPA-A - 20minutos) dificultaram o processo de ignição da reação. A mistura de reagentes como recebidos e com 1,9\% de ACP mostrou um comportamento térmico intermediário aos observados, provavelmente devido a uma redução de tamanho médio de partícula proporcionada pela quantidade maior de ACP.

Em moagens mais longas, o encruamento das partículas e a formação de agregados promovem uma distribuição mais homogênea e fina dos reagentes, afetando diretamente o comportamento térmico durante o ciclo de aquecimento. A FIG.47 apresenta uma comparação do comportamento térmico das misturas com 120 minutos de moagem. Os valores característicos dos perfis de temperatura são reapresentados na TAB.26.

O estado encruado do pó de nióbio pré-ativado formou agregados com dispersão desse elemento na forma globular. O tempo de moagem melhora gradualmente a distribuição dos reagentes. Entretanto, o comportamento térmico semelhante das misturas MPA e MPA-N (ambas com nióbio pré-ativado), com 20 

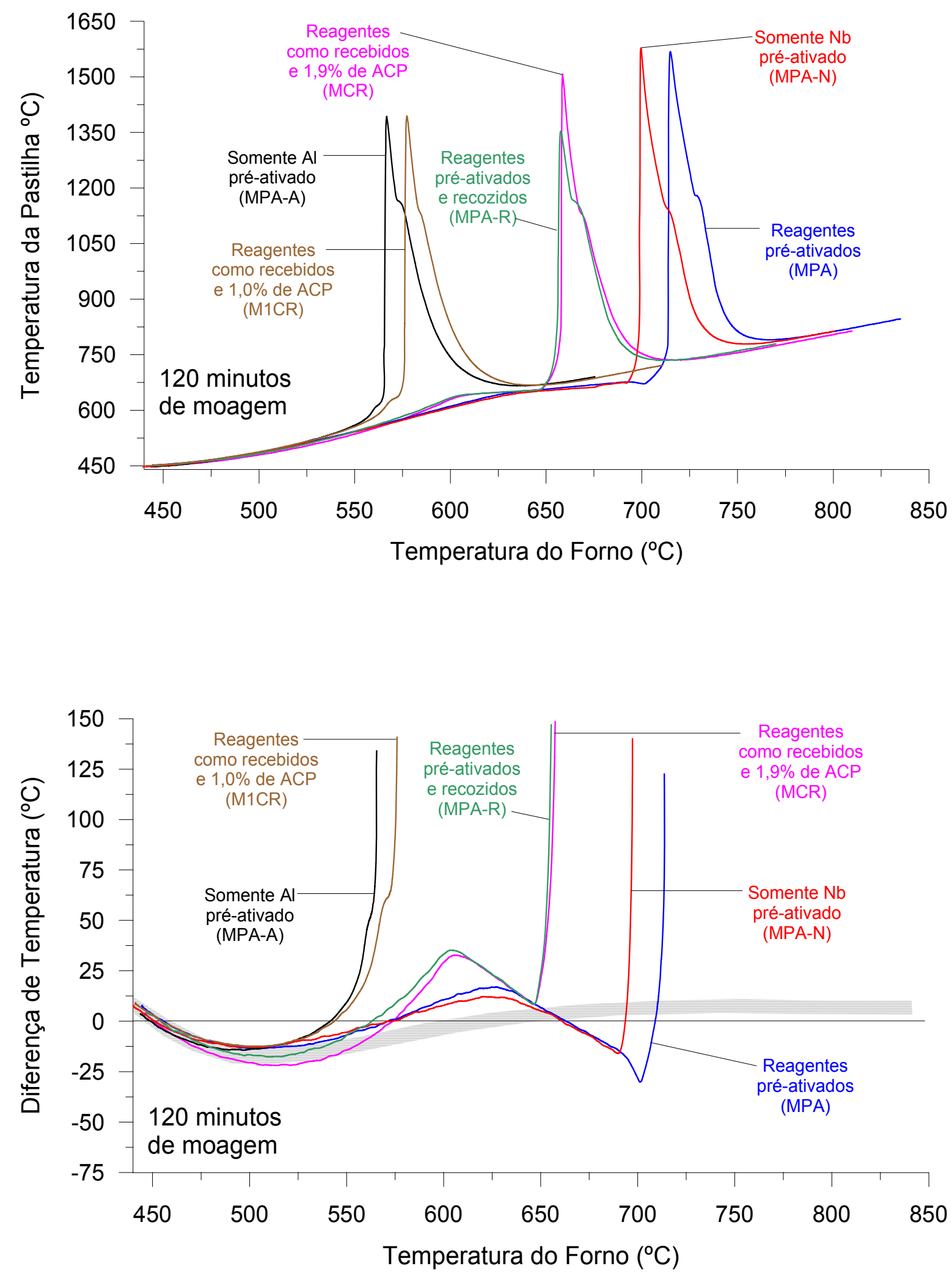

FIGURA 47 - Comparação dos perfis de temperatura e de diferença de temperatura entre pastilha e forno, referentes às pastilhas preparadas a partir de misturas com 120 minutos de moagem. 
TABELA 26 -Valores característicos dos perfis de temperatura para pastilhas preparadas a partir de misturas com 120 minutos de moagem.

\begin{tabular}{|c|c|c|c|c|c|c|}
\hline & M1CR & MCR & MPA & MPA-R & MPA-A & MPA-N \\
\hline $\begin{array}{c}\text { Temperatura } \\
\text { de ignição }\left({ }^{\circ} \mathrm{C}\right)\end{array}$ & $541 \pm 3$ & $659 \pm 1$ & $669 \pm 6$ & $657 \pm 2$ & $542 \pm 3$ & $678 \pm 1$ \\
\hline $\begin{array}{c}\text { Temperatura de } \\
\text { explosão térmica }\left({ }^{\circ} \mathrm{C}\right)\end{array}$ & $740 \pm 23$ & $813 \pm 31$ & $805 \pm 10$ & $867 \pm 1$ & $699 \pm 32$ & $817 \pm 25$ \\
\hline $\begin{array}{c}\text { Temperatura de } \\
\text { Combustão }\left({ }^{\circ} \mathrm{C}\right)\end{array}$ & $1393 \pm 1$ & $1507 \pm 32$ & $1570 \pm 2$ & $1353 \pm 53$ & $1395 \pm 14$ & $1560 \pm 47$ \\
\hline$\Delta \mathrm{T}\left({ }^{\circ} \mathrm{C}\right)$ & $852 \pm 2$ & $847 \pm 32$ & $901 \pm 6$ & $696 \pm 54$ & $852 \pm 12$ & $882 \pm 46$ \\
\hline $\begin{array}{c}\text { Taxa de aquecimento } \\
\text { máxima }\left({ }^{\circ} \mathrm{C} / \mathrm{s}\right)\end{array}$ & $626 \pm 38$ & $1283 \pm 262$ & $1667 \pm 211$ & $412 \pm 77$ & $942 \pm 74$ & $1138 \pm 169$ \\
\hline $\begin{array}{c}\text { Tempo de reação (s) } \\
\text { Tempo }\end{array}$ & $75 \pm 6$ & $24 \pm 2$ & $35 \pm 2$ & $23 \pm 1$ & $50 \pm 4$ & $17 \pm 1$ \\
\hline $\begin{array}{c}\text { Taxa de aquecimento } \\
\left.\text { média ( }{ }^{(} \mathrm{C} / \mathrm{s}\right)\end{array}$ & $11 \pm 1$ & $36 \pm 2$ & $26 \pm 1$ & $30 \pm 2$ & $17 \pm 2$ & $51 \pm 2$ \\
\hline $\begin{array}{c}\text { Tempo de fusão do } \\
\text { alumínio (s) }\end{array}$ & $11 \pm 1$ & $101 \pm 1$ & $196 \pm 9$ & $106 \pm 7$ & $6,3 \pm 0,3$ & $167 \pm 7$ \\
\hline
\end{tabular}

TABELA 27 -Tamanho de cristalito, microdeformação e parâmetro de rede do alumínio e do nióbio pré-ativados e em misturas com 120 minutos de moagem.

\begin{tabular}{|c|c|c|c|c|c|c|}
\hline & M1CR & MCR & MPA & MPA-A & MPA-N & $\begin{array}{c}\text { Somente } \\
\text { pré-ativado }\end{array}$ \\
\hline \hline $\begin{array}{c}\text { Tamanho de cristalito } \\
\text { do alumínio }(\AA)\end{array}$ & $43 \pm 35$ & $45 \pm 38$ & $34 \pm 12$ & $25 \pm 9$ & $39 \pm 11$ & $36 \pm 10$ \\
\hline $\begin{array}{c}\text { Microdeformação do } \\
\text { alumínio }\end{array}$ & $\begin{array}{c}0,00151 \\
\pm 0,00013\end{array}$ & $\begin{array}{c}0,00150 \\
\pm 0,00001\end{array}$ & $\begin{array}{c}0,00151 \\
\pm 0,00011\end{array}$ & $\begin{array}{c}0,00147 \\
\pm 0,00032\end{array}$ & $\begin{array}{c}0,00145 \\
\pm 0,00025\end{array}$ & $\begin{array}{c}0,00135 \\
\pm 0,00001\end{array}$ \\
\hline $\begin{array}{c}\text { Parâmetro de rede do } \\
\text { alumínio }\end{array}$ & $\begin{array}{l}4,0478 \\
\pm 0,0001\end{array}$ & $\begin{array}{c}4,0486 \\
\pm 0,0001\end{array}$ & $\begin{array}{c}4,0460 \\
\pm 0,0001\end{array}$ & $\begin{array}{c}4,0483 \\
\pm 0,0001\end{array}$ & $\begin{array}{c}4,0464 \\
\pm 0,0001\end{array}$ & $\begin{array}{c}4,0491 \\
\pm 0,0001\end{array}$ \\
\hline $\begin{array}{c}\text { Tamanho de cristalito } \\
\text { do nióbio ( } \AA \text { ) }\end{array}$ & $20 \pm 6$ & $26 \pm 10$ & $6,3 \pm 2,8$ & $17 \pm 7$ & $6,2 \pm 2,4$ & $6,6 \pm 3,0$ \\
\hline $\begin{array}{c}\text { Microdeformação do } \\
\text { nióbio }\end{array}$ & 0,00353 & 0,00352 & 0,0075 & 0,00336 & 0,0077 & 0,0074 \\
$\pm 0,00007$ & $\pm 0,00001$ & $\pm 0,0014$ & $\pm 0,00003$ & $\pm 0,0014$ & $\pm 0,0011$ \\
\hline $\begin{array}{c}\text { Parâmetro de rede do } \\
\text { nióbio }\end{array}$ & 3,3098 & 3,3116 & 3,3407 & 3,3120 & 3,3403 & 3,3291 \\
$\pm 0,0001$ & $\pm 0,0001$ & $\pm 0,0001$ & $\pm 0,0001$ & $\pm 0,0002$ & $\pm 0,0002$ \\
\hline
\end{tabular}

e 120 minutos de moagem, mostra que o tempo de moagem tem pouco efeito sobre as condições de reação quando se utiliza nióbio pré-ativado. Esse comportamento está relacionado com a resistência mecânica do nióbio encruado, que praticamente não sofre deformação plástica durante a moagem da mistura. Essa constatação se baseia na manutenção da forma globular das partículas de nióbio durante a moagem (FIG.23 - p.83), do tamanho de cristalito e da microdeformação (ver TAB. 27 acima). A limitação do mecanismo de deformação plástica restringe o aumento da área de superfície específica do nióbio ao 
processo de fratura das partículas. A presença de alumínio em maior fração volumétrica nas misturas $\mathrm{Nb}_{25} \mathrm{Al}_{75}$, dificulta o processo de fratura das partículas de nióbio, devido a maior plasticidade do alumínio. Essa situação produz uma saturação da área de interface, proporcional a área de superfície do nióbio, reduzindo o efeito do tempo de moagem.

As misturas que utilizaram nióbio como recebido (M1CR, MCR e MPA-A) apresentaram comportamentos térmicos muito diferentes para os tempos de $20 \mathrm{e}$ 120 minutos. O tempo mais longo de moagem produziu uma distribuição mais homogênea dos reagentes, numa dispersão lamelar. As misturas M1CR e MPA-A, cuja quantidade de ACP adicionada à mistura, imediatamente antes da moagem, foi menor $(1,0 \%$ e $0.3 \%$, respectivamente), apresentaram uma dispersão muito semelhante entre si (FIG.40C, p.111 e FIG.26D, p.86). Essa semelhança na dispersão foi reproduzida no comportamento térmico das pastilhas, cujas temperaturas de ignição e de combustão foram praticamente idênticas. As taxas de aquecimento média e máxima foram maiores na mistura MPA-A, indicando que a utilização de alumínio pré-ativado aumentou a cinética de reação. Esse efeito pode estar associado a um refino mais intenso da microestrutura, provocado pelo estado encruado das partículas alumínio.

No caso da mistura com $1,9 \%$ de ACP (MCR), o tamanho médio de agregado foi menor ( $11 \mu \mathrm{m}$ para MCR e $36 \mu \mathrm{m}$ para M1CR). Essa diminuição do tamanho do agregado e a presença de partículas isoladas de nióbio na mistura $M C R$, evidenciam o efeito inibidor do ACP sobre o mecanismo de soldagem a frio, diminuindo a formação de interfaces durante a moagem. Entretanto, a presença de quantidades diferentes de ACP não provocou diferenças mensuráveis sobre a densidade de defeitos cristalinos, representadas pelo tamanho de cristalito e pela microdeformação (TAB.27). Portanto, o comportamento térmico diferenciado entre as misturas com 1,0\% (M1CR) e 1,9\% (MCR) de ACP, representado pelo tempo de fusão do alumínio maior, para a mistura MCR, e pela temperatura de ignição mais alta, pode estar associado à formação de uma área de interface menor e também à menor reatividade dessas interfaces, devido à presença de uma maior quantidade de ACP na mistura.

O comportamento térmico antes da temperatura de ignição das misturas MCR (reagentes como recebidos e 1,9\% de ACP) e MPA-R (reagentes pré- 
ativados e recozidos com $1,9 \%$ de ACP) foram muito semelhantes. A cinética de reação foi menor na mistura MPA-R devido a uma grande quantidade de carbonetos de alumínio e de nióbio formados durante o recozimento. O aquecimento da pastilha antes da fusão do alumínio e a redução do tempo de fusão estão relacionados com a formação de $\mathrm{NbAl}_{3}$ por difusão no estado sólido. A intensidade dessa formação depende diretamente da área de interface e da qualidade dessa interface. A semelhança entre os perfis térmicos das misturas $M C R$ e MPA-R indicam que tanto a área quanto a reatividade das interfaces foram equivalentes. $O$ tratamento de recozimento dos reagentes pré-ativados possibilitou que as partículas de nióbio se deformassem durante a moagem da mistura, propiciando distribuições de reagentes semelhantes entre as misturas MPA-R e MCR (FIG.34G - p.104; FIG.36C - p.106).

Concluindo, a deformação plástica das partículas de nióbio, durante a moagem da mistura, propicia um aumento da área de interface com o alumínio. As interfaces formadas sob deformação plástica intensa (misturas M1CR, MCR, MPA-A e MPA-R) apresentaram uma reatividade maior e, consequentemente, uma formação mais intensa de $\mathrm{NbAl}_{3}$ por difusão antes da ignição da reação. No caso das misturas MPA e MPA-N, as interfaces foram formadas através da deformação plástica intensa somente do alumínio, o que provocou uma redução na temperatura de ignição, em relação às misturas simples SPA e SPA-N. Entretanto, o tempo de fusão mais longo para as misturas MPA e MPA-N, com 120 minutos de moagem, indica que a reatividade dessas interfaces é menor, em relação às misturas $\mathrm{M} 1 \mathrm{CR}$ e $\mathrm{MCR}$, a despeito da densidade de defeitos cristalinos mais elevada nas misturas com nióbio pré-ativado. Portanto, a deformação plástica conjunta dos reagentes é o mecanismo mais efetivo de formação de interfaces com maior reatividade, as quais constituem a ativação mecânica propriamente dita. $\mathrm{O}$ agente controlador de processo atua dificultando a formação dessas interfaces e provavelmente diminuindo a reatividade das mesmas pela contaminação das superfícies das partículas. A variação da densidade de defeitos cristalinos entre as misturas, não provocou variações mesuráveis nos perfis de temperatura coletados, indicando que o principal efeito de ativação é provocado pelo aumento da área de interface entre os reagentes. 


\section{CONCLUSÕES}

Os resultados experimentais e as discussões realizadas sobre a síntese por reação de $\mathrm{NbAl}_{3}$ a partir de misturas $\mathrm{Nb}_{25} \mathrm{Al}_{75}$ permitiram formular as seguintes conclusões:

- A ativação mecânica durante a moagem com alta energia está relacionada, fundamentalmente, com o aumento da área de interface entre o nióbio e o alumínio. A densidade de defeitos cristalinos não produziu efeito mensurável sobre o comportamento térmico das pastilhas.

- A eficiência de formação de interfaces depende da deformação plástica dos reagentes e da formação de agregados lamelares desses reagentes. A utilização de nióbio não encruado aumenta a eficiência de formação de interfaces, enquanto que quantidades maiores de agente controlador de processo dificultam a formação dos agregados lamelares.

- O encruamento (pré-ativação) do pó de nióbio alterou a microestrutura dos agregados obtidos na moagem com alta energia, indo de lamelar (nióbio não encruado) a uma dispersão de partículas globulares (nióbio encruado) na matriz de alumínio.

- Moagens mais longas favoreceram a formação de $\mathrm{NbAl}_{3}$ por difusão antes da temperatura de ignição. Esse efeito foi mais pronunciado na moagem de reagentes não encruados (como recebidos) em comparação com a moagem de reagentes encruados (pré-ativados).

- A utilização de agente controlador de processo (ACP) produziu uma contaminação da mistura, devido a sua decomposição durante a moagem, cuja intensidade é proporcional ao tempo de moagem. A conseqüência dessa contaminação foi a formação de óxidos e carbonetos durante o ciclo de aquecimento.

- A formação de compostos insolúveis no alumínio líquido, antes da ignição da reação, provocou a redução da cinética de reação, cuja intensidade de redução foi menor no caso de regentes com tamanho médio de partícula menor ou de agregados com estrutura lamelar mais fina. 
- As pastilhas que atingiram temperaturas de combustão acima de $1590^{\circ} \mathrm{C}$ (temperatura eutética do sistema $\mathrm{Al}-\mathrm{Nb}$ ) formaram estruturas eutéticas $\mathrm{NbAl}_{3}-\mathrm{Nb}_{2} \mathrm{Al}$, indicando um desvio estequiométrico da mistura causado pela perda de alumínio.

- A moagem com alta energia introduziu uma grande quantidade de defeitos cristalinos, aumentando a microdeformação elástica e reduzindo o tamanho de cristalito, formando uma estrutura nanocristalina tanto no nióbio quanto no alumínio. O nióbio foi mais suscetível ao aumento da densidade de defeitos cristalinos.

- A ativação mecânica de misturas $\mathrm{Nb}_{25} \mathrm{Al}_{75}$ produziu os seguintes efeitos no comportamento térmico das pastilhas durante o ciclo de aquecimento:

> redução da temperatura de ignição;

> redução do tempo de fusão do alumínio;

> aumento da cinética da reação de combustão com o refino da microestrutura dos agregados;

> diminuição da cinética da reação de combustão com a formação de $\mathrm{NbAl}_{3}$ por difusão. 


\section{SUGESTÕES PARA TRABALHOS FUTUROS}

1. Caracterização dos materiais pré-ativados e das misturas moídas por microscopia eletrônica de transmissão.

2. Análise térmica diferencial dos materiais pré-ativados e das misturas moídas.

3. Investigação do efeito do tamanho da amostra e da taxa de aquecimento em pastilhas preparadas a partir de misturas moídas.

4. Difração de raios $X$ das pastilhas com interrupção de aquecimento e após a reação de combustão, com subseqüente refinamento dos difratogramas pelo método de Rietveld.

5. Aplicação de modelos específicos de refinamento de difratogramas de raios $X$ para avaliação de densidade de discordância e probabilidade de falha de empilhamento nas misturas moídas e nos reagentes pré-ativados..

6. Caracterização química dos produtos de moagem. 


\section{ANEXO}

O programa MAUD® utilizado neste trabalho tem como base, para as análises dos difratogramas, o método de Rietveld e os procedimentos apresentados por Lutterotti e Scardi (1990), Scardi et al. (1994), Lutterotti e Gialanella (1998) e Popa (1998).

O método de Rietveld $(1967,1968)$ é baseado no ajuste da intensidade de difração, calculada por uma função teórica, aos dados experimentais, através do método não linear de mínimos quadrados. O ajuste é realizado pela variação dos parâmetros da função, processo este, denominado refinamento, cujo objetivo é minimizar a soma quadrática ponderada dos desvios entre valores experimentais e valores calculados ponto a ponto, determinada pela equação:

$$
W S S=\sum_{i=1}^{N}\left[w_{i}\left(I_{i}^{\exp }-I_{i}^{\text {calc }}\right)\right]^{2} \quad \text { sendo que }: w_{i}=\frac{1}{\sqrt{I_{i}^{\exp }}}
$$

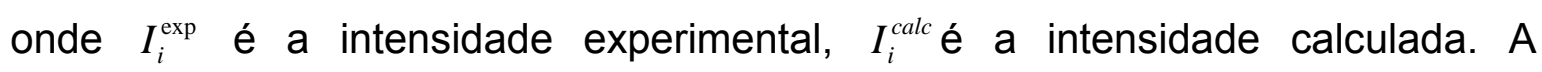
qualidade de ajuste depende da qualidade dos dados experimentais, que pode ser avaliada pela seguinte expressão:

$$
R_{\exp }=\sqrt{\frac{(N-P)}{\sum_{i=1}^{N}\left(w_{i} I_{i}^{\exp }\right)^{2}}}
$$

onde $\boldsymbol{N}$ é o número de pontos do difratograma e $\boldsymbol{P}$ é o número de parâmetros refinados. A estimativa do melhor ajuste possível é fornecida por $R_{\exp }$. A qualidade de ajuste é determinada por:

sendo que:

$$
\begin{gathered}
\text { Qualidade de ajuste }=\frac{R_{w p}}{R_{\exp }} \\
R_{w p}=\sqrt{\frac{\sum_{i=1}^{N}\left[w_{i}\left(I_{i}^{\exp }-I_{i}^{\text {calc }}\right)\right]^{2}}{\sum_{i=1}^{N}\left(w_{i} I_{i}^{\exp }\right)^{2}}}
\end{gathered}
$$


A intensidade calculada pelo progama $M A U D \circledR$ é determinada pela seguinte expressão:

$$
I_{i}^{\text {calc }}=S_{F} \sum_{j=1}^{n=\text { fases }} \frac{f_{j}}{V_{j}^{2}} \sum_{k=1}^{n=p i \cos } L_{k}\left|F_{k, j}\right|^{2} \phi_{j}\left(2 \theta_{i}-2 \theta_{k, j}\right) P_{k, j} A_{j}+b k g_{i}
$$

A radiação de fundo (background) é modelada por uma equação polinomial de grau $\boldsymbol{n}$, do tipo: $b k g_{i}=\sum_{n=0}^{n=g r a u} a_{n}\left(2 \theta_{i}\right)^{n}$, onde $a_{n}$ são os coeficientes polinomiais.

O fator de escala da fase j é determinado por: $S_{j}=S_{F}\left(f_{j} / V_{j}^{2}\right)$, onde $S_{F}$ é a intensidade do feixe de raios $\mathrm{X}, f_{j}$ é a fração volumétrica da fase $\boldsymbol{j}$, e $V_{j}$ é o volume da célula cristalina da fase $\boldsymbol{j}$.

O fator de polarização de Lorentz, $L_{k}$, depende do aparato instrumental utilizado e pode ser determinado por:

$$
L_{k}=\frac{1+P \cos ^{2}(2 \theta)}{2(1+P) \sin ^{2} \theta \cos \theta}
$$

sendo que: $P=\cos ^{2}(2 \alpha)$; onde $\alpha$ é o ângulo característico do monocromador.

O Fator de estrutura, $F_{k, j}$, é definido como:

$$
\left|F_{j, k}\right|^{2}=m_{k} \mid \sum_{n=1}^{n_{\text {atomos }}} f_{n} e^{\left(-B_{n} \frac{\sin ^{2} \theta}{\lambda^{2}}\right)}\left(e^{2 \pi i\left(h x_{n}+k y_{n}+l z_{n}\right.}\right)^{2}
$$

onde $m_{k}$ é o fator de multiplicidade da pico $\mathrm{k}, f_{n}$ é o fator de espalhamento atômico, $B_{n}$ é o fator de temperatura, $x_{n}, y_{n}, z_{n}$ são as coordenadas do enésimo átomo e $h, k, l$ são os índices de Miller relativos aos planos que deram origem ao pico $k$. 
Os fatores $P_{k, j}$ e $A_{j}$ são relativos à correção da orientação preferencial e da microabsorção de raios X. O programa MAUD® disponibiliza diversos modelamentos para o refinamento desses parâmetros, dentre eles o apresentado por Dollase (1986), para a correção da orientação preferencial, e o apresentado por Brindley (1945), para a correção da microabsorção.

O perfil dos picos de difração é determinado pela função $\phi_{j}\left(2 \theta_{i}-2 \theta_{k, j}\right)$, onde $2 \theta_{k, j}$ é a posição da intensidade máxima do pico $\boldsymbol{k}$ da fase $\boldsymbol{j}$, sendo determinado por:

$$
\begin{aligned}
& 2 \theta_{k, j}=2 \arcsin \left(\frac{\lambda \sqrt{s_{11} h^{2}+s_{22} k^{2}+s_{33} I^{2}+s_{12} h k+s_{13} h l+s_{23} k l}}{2 V_{c}}\right) \\
& S=\left(\begin{array}{ccc}
a^{* 2} & a^{*} b^{*} \cos \left(\gamma^{*}\right) & a^{*} c^{*} \cos \left(\beta^{*}\right) \\
a^{*} b^{*} \cos \left(\gamma^{*}\right) & b^{* 2} & b^{*} c^{*} \cos \left(\alpha^{*}\right) \\
a^{*} c^{*} \cos \left(\beta^{*}\right) & b^{*} c^{*} \cos \left(\alpha^{*}\right) & c^{* 2}
\end{array}\right)
\end{aligned}
$$

onde: $h, k, l$ são os índices de Miller, $a^{*}, b^{*}, c^{*}$ são os parâmetros de rede no espaço recíproco e $\alpha^{*}, \beta^{*}, \gamma^{*}$ são os ângulos da célula cristalina no espaço recíproco.

O perfil do pico de difração é determinado pela convolução do perfil produzido pelo conjunto instrumental e do perfil produzido pela amostra. A largura à meia altura (largura medida na metade da intensidade máxima do pico) de cada pico varia em função do tipo de instrumentação utilizada e das características microestruturais da amostra. $\mathrm{O}$ alargamento instrumental é determinado pelo refinamento de um difratograma de uma amostra com tamanho de cristalito acima de $100 \mathrm{~nm}$ e com microdeformação elástica nula. O perfil dos picos é modelado pela convolução de uma função pseudo-Voigt, referente à fração simétrica do pico, com uma função exponencial, que descreve a assimetria do pico. A equação assume a seguinte forma:

$$
E\left(2 \theta_{i}\right)=(S * A)\left(2 \theta_{i}\right)
$$


Sendo que: $\quad S\left(2 \theta_{i}\right)=I_{k, j}\left[(1-\eta) L\left(2 \theta_{i}\right)+\eta G\left(2 \theta_{i}\right)\right]$

$$
\begin{aligned}
& A\left(2 \theta_{i}\right)=\exp \left[-a\left|2 \theta_{i}-\theta_{k, j}\right| \tan \left(2 \theta_{k, j}\right)\right] \\
& L_{S}\left(2 \theta_{i}\right)=\frac{1}{1+\left(\frac{2 \theta_{i}-2 \theta_{k, j}}{w}\right)^{2}} \\
& G_{S}\left(2 \theta_{i}\right)=\exp \left[-(\ln 2)\left(\frac{2 \theta_{i}-2 \theta_{k, j}}{w}\right)^{2}\right]
\end{aligned}
$$

onde: $\eta$ é o parâmetro misturador das funções gaussiana e lorentziana, $a$ é o parâmetro de decaimento da função exponencial e $w$ é a metade da largura do pico à meia altura da intensidade máxima.

A largura integrada total (largura do pico retangular de mesma área), relativa às larguras integradas das funções gaussiana e lorentziana, pode ser determinada a partir de $\eta$ e $2 w$ pela expressão:

$$
\beta=w\left[\eta \pi+(1-\eta)\left(\sqrt{\frac{\pi}{\ln 2}}\right)\right]
$$

A variação da largura à meia altura $(2 w)$ em função do ângulo $2 \theta$ é avaliada pelo refinamento dos parâmetros da fórmula proposta por Caglioti et al. (1958):

$$
(2 w)^{2}=U \tan ^{2}\left(\theta_{k, j}\right)+V \tan \left(\theta_{k, j}\right)+W
$$

A proporção entre as funções gaussiana e lorentziana $(\eta)$ também varia em função de $2 \theta$, e pode modelado por uma função polinomial do tipo:

$$
\eta=\sum_{n=0}^{n=g r a u} a_{n}\left(2 \theta_{k, j}\right)^{n}
$$

O perfil experimental dos picos de difração é dado por:

$$
\phi\left(2 \theta_{i}\right)=\left(E^{*} B\right)\left(2 \theta_{i}\right)
$$


onde $B\left(2 \theta_{i}\right)$ representa $\circ$ alargamento produzido pelas características microestruturais da amostra. Esse alargamento pode ser determinado se o tamanho médio de cristalito e a microdeformação elástica média forem conhecidas. Popa (1998) propôs um método para determinar o tamanho de cristalito e microdeformação elástica em situações isotrópicas ou anisotrópicas. No caso do sistema cúbico, a microdeformação elástica quadrática média, perpendicular ao plano $h, k, l$, é definida como:

$$
\left\langle\varepsilon_{h k l}^{2}\right\rangle=\left[E_{1}\left(h^{4}+k^{4}+l^{4}\right)+2 E_{2}\left(h^{2} k^{2}+k^{2} l^{2}+l^{2} h^{2}\right)\right]\left(\frac{d_{h k l}}{a}\right)^{4}
$$

onde: $d_{h k l}$ é o espaçamento interplanar, $a$ é o parâmetro de rede da célula cristalina e $E_{1}$ e $E_{2}$ são os parâmetros a serem refinados.

O tamanho de cristalito médio é determinado por uma série convergente de harmônicos esféricos simétricos, que, para o caso do sistema cúbico, tem a seguinte forma:

$$
\left\langle R_{h k l}\right\rangle=R_{0}+R_{1} K_{1}^{4}(x, \varphi)+R_{2} K_{1}^{6}(x, \varphi)+\ldots
$$

sendo que:

$$
\begin{gathered}
K_{l}^{m}(x, \varphi)=(2 \pi)^{-1 / 2} \exp (\operatorname{im} \varphi) P_{l}^{m}(x) \\
P_{l}^{m}(x)=\left[\frac{(l+m) !}{(l-m) !}\right]^{1 / 2}\left(1+\frac{1}{2}\right)^{1 / 2}(-1)^{(l-m)}\left(\frac{2^{-1}}{l !}\right)\left(1-x^{2}\right)^{-(m / 2)} \frac{d^{(l-m)}\left(1-x^{2}\right)^{m}}{d x^{(l-m)}} \\
x=\cos \Phi=d_{h k l} l a \quad \tan \varphi=\left(\frac{k}{h}\right)
\end{gathered}
$$

onde: $h, k, l$ são os índices de Miller, $a$ é o parâmetro de rede, $d_{h k l}$ é o espaçamento interplanar e $R_{0}, R_{1}, \ldots R_{n}$ são os parâmetros a serem refinados, cujo número depende do grau de anisotropia do tamanho de cristalito. Os valores de $l$ e $m$ são definidos pelas regras definidas por Popa (1992).

O modelamento de alargamento dos picos de difração apresentado por Popa (1998) considera que o tamanho de cristalito está relacionado com a função 
lorentziana e a microdeformação elástica com a função gaussiana. As larguras integradas das funções gaussiana e lorentziana podem ser determinadas por:

$$
\begin{gathered}
\beta_{G B(h k l)}=2 \tan \theta_{k, j} \sqrt{2 \pi\left\langle\varepsilon_{h k l}^{2}\right\rangle} \\
\beta_{L B(h k l)}=\frac{2 \lambda}{3\left\langle R_{h k l}\right\rangle \cos \theta_{k, j}}
\end{gathered}
$$

As componentes gaussiana e lorentziana do perfil do pico de difração são dadas por:

$$
\begin{aligned}
L_{B}\left(2 \theta_{i}\right) & =\frac{1}{\beta_{L B}\left[1+\left(\pi \frac{2 \theta_{i}-2 \theta_{k, j}}{\beta_{L B}}\right)^{2}\right]} \\
G_{B}\left(2 \theta_{i}\right) & =\frac{\exp \left[-\pi\left(\frac{2 \theta_{i}-2 \theta_{k, j}}{\beta_{G B}}\right)^{2}\right]}{\beta_{G B}}
\end{aligned}
$$

O perfil resultante da convolução das funções gaussiana e lorentziana é dado pela função Voigt na seguinte forma:

$$
B_{V}(x)=\int G_{B}(z) L_{B}(x-z) d z
$$

sendo que: $x=\theta_{i}-\theta_{k, j}$.

A eliminação do alargamento provocado pelo aparato instrumental utilizado, $E\left(2 \theta_{i}\right)$, pode ser realizada utilizando as respectivas larguras integradas, na seguinte forma:

$$
\begin{gathered}
\beta_{G B}=\sqrt{\left(\beta_{G \phi}\right)^{2}-\left(\beta_{G E}\right)^{2}} \\
\beta_{L B}=\beta_{L \phi}-\beta_{L E}
\end{gathered}
$$




\section{REFERÊNCIAS BIBLIOGRÁFICAS}

ALEFELD, G.; VÖLKL, J. Hydrogen in metals; Berlin: Springer, 1978.

AOKI, K.; IZUMI, O. Improvement in room temperature ductility of $L_{12}$ type intermetallic compound $\mathrm{Ni}_{3} \mathrm{Al}$ by boron addition; Journal of Japan Institute of Metals V.43, p.1190, 1979.

BARIN, I. Thermodynamical data of pure substances, Cambridge: Weinheim, 1989.

BARMAK, K.; COFFEY, K.R.; RUDMAN, D.A. The effect of oxygen on phase formation in Al/Nb diffusion couples; Journal of Applied Physics V.67, p.3780, 1990.

BAKER, I.; GEORGE, E. P. Intermetallic compounds: an update. Metals and Materials V.8, n. 6, p.318, 1992.

BEI, H.; PHARR, G.M.; GEORGE, E.P. A review of directionally solidified intermetallic composites for high-temperature structural applications; Journal of Materials Science V.39 p.3975, 2004.

BENJAMIN, J.S.; VOLIN, T.E. Mechanisms of Mechanical alloying; Metallurgical Transactions V.5, p.1929, 1974.

BENJAMIN, J.S. Dispersion strengthened superalloys by mechanical alloying; Metallurgical Transactions V.1, p. 2943, 1970.

BEWLAY, B.P., JACKSON, M.R.; ZHAO, J.C.; SUBRAMANIAN, Pr. A Review of Very-High-Temperature Nb-Silicide-Based Composites; Metallurgical and Materials Transactions V.34A, p.2043, 2003.

BOLDYREV, V.V. Mechanical activation and its application in technology; Materials Science. Forum V. 269-272, p.227, 1998.

BOZZOLO, G.; NOEBE, R.D.; AMADOR, C. Site occupancy of ternary additions to B2 alloys; Intermetallics V.10, p.149, 2002.

BOZZOLO, G.; NOEBE, R.D.; HONECY, F. Modeling of ternary element site substitution in NiAl; Intermetallics V.8, p.7, 2000.

BRINDLEY, G.W. The Effect of Particle Size and Microabsorption on Diffracted Powder Line Intensities; Philosophical Magazine V.36, p.347, 1945.

CAGLIOTI, G.; PAOLETTI, A.; RICCI, F.P. Choice of Collimators for a crystal spectrometer for neutron diffraction; Nuclear Instruments V.3, p.223, 1958.

CAMMAROTA, G.P.; CASAGRANDE, A. Effect of ternary additions of iron on microstructure and microhardness of the intermetallic NiAl in reactive sintering; Journal of Alloys and Compounds V.381, p.208, 2004.

COCCO, G.; DELOGU, F.; SCHIFFINI, L. Toward a quantitative understanding of the mechanical alloying process Journal of Materials Synthesis and Processing V.8, p.167, 2000. 
COTTON, J.D.; NOEBE, R.D; KALFMAN, M.J. The effects of chromium on NiAI intermetallic alloys: Part I. Microstructures and mechanical properties; Intermetallics V.1, p.3, 1993a.

COTTON, J.D.; NOEBE, R.D; KALFMAN, M.J. The effects of chromium on NiAI intermetallic alloys: Part II. Slip systems; Intermetallics V.1, p.117, 1993b.

DEEVI, S.C.; SIKKA, V.K. Nickel and iron aluminides: An overview on properties, processing, and applications; Intermetallics V.4, p.357, 1996.

DOLLASE, W.A. Correction of intensities for preferred orientation in powder diffractometry: application of the March model; Journal of Applied Crystallography V.19, p.267, 1986.

ENAYATI, M. H.; SEYED-SALEHI, M.; SONBOLI, A. Development of $\mathrm{Fe}_{3} \mathrm{C}, \mathrm{SiC}$ and $\mathrm{Al}_{4} \mathrm{C}_{3}$ compounds during mechanical alloying; Journal of Materials Science V.42, p.5911, 2007.

ESTRIN, Y.; RABKIN, E. Pipe diffusion along curved dislocations: an application to mechanical alloying; Scripta Metallurgica V.39, p.1731, 1998.

EVSTIGNEEV, V.V.; FILIMONOVET, V.YU; KOSHELEV, K.B. Mathematical model of phase-formation processes in a binary mixture of $\mathrm{Ti}$ and $\mathrm{Al}$ powders in the regime of a nonadiabatic thermal explosion; Combustion Explosion and Shock Waves V.43, p. 170, 2007.

FARBER, V.M. Contribution of diffusion process to structure formation in intense cold plastic deformation of metals; Metals Science and Heat Treatment V.44, p.317, 2002.

FERNANDES, B.B.; RODRIGUES, G.; SILVA, G.; RAMOS, E.C.T.; NUNES, C.A.; SANDIM, H.R.Z.; RAMOSA, A.S. On the $T_{2}$-phase formation in mechanically alloyed $\mathrm{Nb}-\mathrm{Si}$ and $\mathrm{Nb}-\mathrm{Si}-\mathrm{B}$ powders; Journal of Alloys and Compounds V.434-435, p.530, 2007.

FERREIRA, P.I.; LEAL NETO, R.M. Reactive sintering of $\mathrm{NbAl}_{3}$; International Journal of Powder Metallurgy V.30, p.313. 1994.

FLEISCHER, R.L. The distribution of boron in AIRu: Effect on ductility and toughness; Acta Materialia V.53, p.2653, 2005.

GAFFET, E.; MALHOUROUX-GAFFET, N. Nanocrystalline $\mathrm{MoSi}_{2}$ phase formation induced by mechanically activated annealing; Journal of Alloys and Compounds V.205, p.27, 1994.

GAUTHIER, V.; BERNARD, F.; GAFFET, E.; JOSSE, C.; LARPIN, J. P.; Synthesis of niobium aluminides using mechanically activated selfpropagating high-temperature synthesis and mechanically activated annealing process; Materials Science and Engineering V.A265, p.117, 1999.

GAUTHIER, V.; BERNARD, F.; GAFFET, E.; VREL, D.; GAILHANOU, M. LARPIN, J. P. Investigations of the formation mechanism of nanostructured $\mathrm{NbAl}_{3}$ via MASHS reaction; Intermetallics V.10, p.377, 2002. 
HAYASHI, T.; MARUYAMA, T. High temperature oxidation of $\mathrm{NbAl}_{3}$ and the improvement of oxidation resistance by dispersion of $\mathrm{Mg}$-compounds Journal of the Japan Institute of Metals V.64, p.1062, 2000.

HELLSTERN, E.; SCHULTZ, L. Phase formation on mechanically alloyed Nb-Al powders Appl. Phys. Lett. V.53, p.1399, 1988.

HIBINO, A.; MATSUOKA, S.; KIUCHI, M. Synthesis and sintering of $\mathrm{Ni}_{3} \mathrm{Al}$ intermetallic compound by combustion synthesis process; Journal of Materials Processing Technology V.112, p.127, 2001.

IVLEVA, T.P.; MERZHANOV, A.G. Modeling of Solid-State Combustion in Thermally and Chemically Heterogeneous Media; Combustion Explosion and Shock Waves V.43, p.636, 2007.

KACHELMYER, C. R., ROGACHEV, A. S.; VARMA, A. Mechanistic and processing studies in combustion synthesis of niobium aluminides. Journal of Materials Research V.10, n. 9, p.2260, 1995.

LAI, M.O.; LÜ, L. Mechanical Alloying. Boston, MA: Kluwer Academic Publishers, 1998.

LEAL NETO, R.M.; FERREIRA, P.I. Progress of the $\mathrm{NbAl}_{3}$ Combustion Synthesis Reaction; Journal of Materials Synthesis and Processing V.7, p.245, 1999.

LEAL NETO, R.M.; FERREIRA, P.I., Reaction sintering of Nb-Ni-Al intermetallics alloys; Materials Science and Engineering V.A193, p.549, 1995.

LEAL NETO, R.M.; ROCHA, C.J. Effect of the high-energy ball milling on the combustion synthesis of $\mathrm{NbAl}_{3}$; Key Engineering Materials, V. 189, p.567, 2001.

LEAL NETO, R.M.; ROCHA, C.J.; AMBROZIO, F. Combustion synthesis of highenergy ball-milled $\mathrm{Nb}+3$ Alpowder mixtures; Materials Science. Forum V.416-418, p.156, 2003

LIU, C.T.; STRINGER, J.; MUNDY, J.N.; HORTON, L.L.; ANGELINI, P. Ordered intermetallic alloy: an assessment; Intermetallics V.5, p.579, 1997.

LU , L.; GOKHALE, A. B.; ABBASCHIAN, R. In situ formation of an alumina interface coating in reactively synthesized $\mathrm{NbAl}_{3}-\mathrm{Nb}$ composites; Materials Science and Engineering V.A144, p.11, 1991.

LUCADAMO, G.; BARMAK, K. Stress evolution in polycrystalline thin film reactions Thin Solid Films V.389, p.8, 2001.

LUCADAMO, G.; BARMAK, K.; CARPENTER, D.T.; RICKMAN, J.M. Microstructure evolution during solid state reactions of $\mathrm{Nb}$-Al multilayers; Acta Materialia V.49, p.2813, 2001.

LUTTEROTTI, L.; GIALANELLA, S. X-ray diffraction characterization of heavily deformed metallic specimens; Acta Materialia V.46, p.101, 1998.

LUTTEROTTI, L.; SCARDI, P. Simultaneous Structure and Size-Strain Refinement by the Rietveld Method; Journal of Applied Crystalography V.23, p.246, 1990. 
MALHOUROUX-GAFFET, N.; GAFFET, E., Solid state reaction induced by postmilling annealing in the Fe-Si system; Journal of Alloys and Compounds V.198, p.143, 1993.

MASLOV, V. M.; BOROVINSKAYA, I. P.; ZIATDNIVOV, M. Kh. Combustion of the systems niobium - aluminum and niobium - germanium. Combustion Explosion and Shock Waves V.15, p.41, 1979.

MASSALSKI, T. B. Binary alloy phase diagrams, Materials Park: ASM, $3^{\text {rd }}$ ed., p.180, 1996.

MERZHANOV, A. G. Fundamentals, achievements, and perspectives for development of solid-flame combustion; Russian Chemical Bulletin V.46, p.1, 1997.

MERZHANOV, A. G. SHS-process: combustion theory and practice. Archivum Combustionis V.1, n.1/2, p.23, 1981.

MIURA, S.; OHASHI, T.; MISHIMA, Y. Amount of liquid phase during reaction synthesis of nickel-aluminides. Intermetallics, v.5, n.1, p.45, 1997.

MOORE, J.; FENG,H.J.; Combustion synthesis of advanced materials - Part I. reaction parameters; Progress of Materials Science V.39, p.243, 1995a.

MOORE, J.; FENG,H.J.; Combustion synthesis of advanced materials- Part II. Classification, applications and modelling; Progress of Materials Science V.39, p.243, 1995b.

MUNIR, Z. A. Synthesis of high temperature materials by self-propagating combustion methods. American Ceramic Society Bulletin V.67, n.2, p.342, 1988.

MUNIR, Z. A. The Synthesis and Consolidation of Powders by Self-Propagating Combustion Methods; Reviews in Particulate Materials V.1, p.41, 1993.

MUNIR, Z. A.; ANSELMI-TAMBURINI, U, OHYANAGI, M. The effect of electric field and pressure on the synthesis and consolidation of materials: A review of the spark plasma sintering method; Journal of Materials Science V.41, p.763, 2006.

MUNIR, Z. A.; ANSELMI-TAMBURINI, U. Self-propagating exothermic reactions: the synthesis of high-temperature materials by combustion. Materials Science Reports V.3, n. 7-8, p.277, 1989.

MURRAY, J.C.; GERMAN, R.M. Reactive sintering and reactive hot isostatic compaction of niobium aluminide $\mathrm{NbAl}_{3}$; Metallurgical Transactions $\mathrm{V} .23$, p.2357, 1992.

OGURTANI,T. Kinetics of diffusion in the Nb-Al system. Metallurgical Transactions V.3, n.2, p.421, 1972.

POPA, N.C. The (hkl) Dependence of Diffraction-Line Broadening Caused by Strain and Size for all Laue Groups in Rietveld Refinement; Journal of Applied Crystalography V.31, p.176, 1998. 
POPA, N.C. Textures in Rietveld Refinement; Journal of Applied Crystalography V.25, p.611, 1992.

POPOVA; E. N.; POPOV; V. V.; ROMANOV, E. P.; PILYUGIN,V. P. Thermal stability of nanocrystalline $\mathrm{Nb}$ produced by severe plastic deformation; Physics of Metals and Metallography V.101, p.52, 2006.

PORTNOY, V.K.; TRETJAKOV, K.V.; STRELETSKII, A.N.; BARESTETSKAYA, I.V. Mechanochemical synthesis of niobium hydrides; Materials Science. Forum V.343-346, p.453, 2000.

RAISSON, G.; VIGNE, A. Oxidation et phenomene de peste de l'aluminiure de niobium $\mathrm{NbAl}_{3}$. Revue de Physique Appliquée, V.5, n.6, p.535, 1970.

RAMANUJAN, R.V. The Role of Refractory Metals in the Development of Structural Intermetallic Compounds; Mineral Processing and Extractive Metallurgy Review V.22, p.615, 1998.

RIETVELD, H.M. A profile refinement method for nuclear and magnetic structures. Journal of Applied Crystalography V.2, p.65, 1969.

RIETVELD, H.M. Lines profiles of neutron powder-diffraction peaks for structure refinement. Acta Crystallographica V. 22, n.1, p.151, 1967.

RIGNEY J.D.; SINGH P.M.; LEWANDOWSKI J.J. Environmental-effects on Ductile-phase toughening in $\mathrm{Nb}_{5} \mathrm{Si}_{3}-\mathrm{Nb}$ composites; JOM-Journal of the Minerals Metals and Materials Society V.44, n.8, p.36, 1992.

ROBIN, A.; SANDIM, H.R.Z. Degradation behavior of niobium in molten aluminum; International Journal of Refractory Metals and Hard Materials V.20, p.221, 2002.

ROCHA, C.J. .; GONÇALVES, V.S.; LEAL NETO, R.M. Mechanical Activation of Nb75Al Mixtures Using Shaker and Planetary Ball Mills; Materials Science. Forum V.530-531, p.203, 2006.

ROCHA, C.J.; ARAÚJO, E.G.; NOGUEIRA, R.A.; AMBROZIO, F. Effect of wax addition on Monel synthesis by high energy ball milling; Materials Science. Forum V.299-300, p.457,1999.

ROCHA, C.J.; LEAL NETO, R.M.; GONÇALVES, V.S.; CARVALHO, L.L.; AMBROZIO, F. An investigation of the use of stearic acid as a process control agent in high energy ball milling of $\mathrm{Nb}-\mathrm{Al}$ and $\mathrm{Ni}-\mathrm{Al}$ powder mixtures Materials Science. Forum V.416-418, p.144, 2003.

ROGACHEV, A. S.; MUKASYAN,A. S.; VARMA, A. Volume Combustion Modes in Heterogeneous Reaction Systems; Journal of Materials Synthesis and Processing V.10, p.31, 2002.

SCARDI, P.; LUTTEROTTI, L.; MAISTRELLI,P. Experimental Determination of the Instrumental Broadening in the Bragg-Brentano Geometry; Powder Diffraction V.9, p.180, 1994.

SCHWARZ, R. B. Microscopic model for mechanical alloying; Materials Science. Forum V.269-272, p.665, 1998. 
SHAW, M.C. Mechanical Activation - A newly developed chemical process; Journal of Applied Mechanics. V.3, p.37, 1948.

SHILO, I.; FRANZEN, H.; F.; SCHIFFMAN R. A. Enthalpies of formation of niobium aluminides as determined by the Knudsen effusion method. Journal of Electrochemical Society V.129, n.7, p.1608, 1982.

SHTREMEL, M.A. Participation of diffusion in processes of mechanical alloying; Metals Science and Heat Treatment V.44, p.324, 2002.

SKAKOV, YU A. High-energy cold plastic deformation, diffusion and mechanochemical synthesis; Metals Science and Heat Treatment V.44, p.137, 2004.

SLAGMA, G.; VIGNES, A. Diffusion dans les aluminiures de niobium. Journal of Less-Common Metals V.29, n.2, p.189, 1972.

SAUTHOFF, G. Intermetallics; Weinheim, New York, p.5, 1995.

STEINHORST, M.; GRABKE, H.J. Oxidation of niobium aluminide $\mathrm{NbAl}_{3}$; Materials Science and Engineering V.A120, p.55, 1989.

STEINIKE, U.; TKACOVA, K. Mechanochemistry of Solids-Real Structure and Reactivity; Journal of Materials Synthesis and Processing V.8, p.197, 2000.

STOLOFF, N.S.; LIU, C.T.; DEEVI, S.C. Emerging applications of intermetálics; Intermetallics V.8, p.1313, 2000.

STRELETSKII, A. N.; POVSTUGAR, I. V.; BORUNOVA, A. B.; LOMAEVA, S. F.; BUTYAGIN, P. YU. Mechanochemical Activation of Aluminum. 4. Kinetics of Mechanochemical Synthesis of Aluminum Carbide; Colloid Journal V.68, n-4, p.470, 2006.

SUBRAHMANYAM, J.; VIJAYAKUMAR, M. Self-propagating high-temperature synthesis, Journal of Materials Science V. 27, p.6249, 1992.

SURYANARAYANA, C. Mechanical alloying and milling; Progress of Materials Science V.46, p.1, 2001.

SURYANARAYANA, C.; $\mathrm{KOCH}$, C.C. Nanocrystalline materials - Current research and future directions Hyperfine Interactions V. 130, p.5, 2000.

SURYANARAYANA, C; ZHOU, E.; PENG, Z.; FROES, F.H. Synthesis of ordered $\mathrm{Al}_{3} \mathrm{Nb}$ intermetallic by mechanical alloying; Scripta Metallurgica et Materialia V.30, p.761, 1994.

SWALIN, R. A. Thermodynamics of solids. New York, N.Y.: John Wiley \& Sons, 1962, p.61.

TAKACS, L. Self-sustaining reactions induced by ball milling Progress of Materials Science V.47, p.355, 2002.

TAKACS, L.; SEPELAK, V. Quantitative comparison of the efficiency of mechanochemical reactors, Journal of Materials Science V.39, p.5487, 2004. 
TAKACS, L.; SOIKA, V.; BALAZ, P. The effect of mechanical activation on highly exothermic powder mixtures; Solid State Ionics V.141-142, p.641, 2001.

TOLPYGO, V.K.; GRABKE, H.J. Mechanism of the intergranular disintegration (pest) of the intermetallic compound $\mathrm{NbAl}_{3}$; Scripta Metallurgica et Materialia V.28, p.747, 1993.

TUNKA, N.; DELAMORE, G.W.; SMITH, R.W. Corrosion of Mo, Nb, Cr, and $Y$ in Molten Aluminum Metallurgical Transactions V.21A, p.1919, 1990.

TUNKA, N.; SMITH, R.W. Intermetallic Compound Layer Growth at the Interface of Solid Refractory Metals Molybdenum and Niobium with Molten Aluminum; Metallurgical Transactions V.20A, p.825, 1989.

WARD-CLOSE, C.M.; MINOR, R.; DOORBAR, P.J. Intermetallic-matrix composites-a review; Intermetallics V.4, p.217, 1996.

YOOSOON, I.; MORRIS JR., J.W. Sequence of phase formation in Nb-Al multilayered samples; Journal of Applied Physics V.64, p.3487, 1988. 